\title{
Conspectus of the Sphecid wasps of Egypt (Hymenoptera: Ampulicidae, Sphecidae, Crabronidae)
}

\section{Giles Roche*}

Lot 44, Taman Wong Wo Lo, Phase 1, Jalan Tun Mustapha, 87008 W.P. Labuan, MALAYSIA

(Email: cgroche172@,hotmail.com)

\section{Historical background}

The sphecid wasps of Egypt and the Sinai have received much attention ever since Spinola wrote his paper in 1839 on the wasps collected by Fischer. He listed 29 species, all of which were described as new. The next main contribution was Walker's unfortunate paper of 1871 . His descriptions were seriously inadequate and his type material has disappeared, destroyed by dermestids (Innes 1912). Thus of the 27 species he created, 22 are unidentifiable and are, therefore, mere lumber in the literature. Next was Kohl's paper of 1897 in which he dealt with the material collected by Schmiedeknecht: a number of species have as their type locality "Adelen Inseln", which is now known to be an island in the Nile opposite Dahshour (see Morice 1900a). A few more species were added to the Egyptian list by Morice $(1897 \mathrm{a}, \mathrm{b})$ and Storey (1916).

Egyptian sphecidology received its main boost in the 1930s and 1940s which saw a whole series of papers by Mochi \& Mochi (1937), Mochi (1939a, b \& c and 1940), Honoré (1941a \& b, 1942, 1944a \& b) and Alfieri (1946), all of them long-term residents in Egypt and most being considerable collectors. De Beaumont published two papers on Tachysphex in 1940 and 1947 that greatly assisted the determination of that difficult genus. This period received a late extension by the appearance of Priesner's 1958 paper on Bembix; he was the principle entomologist of the Ministry of Agriculture. His importance was the fact that of the sphecidologists at that time in Cairo, he was the only one professionally trained.

Subsequently, de Beaumont (1950c) reported the results of the Omer-Cooper expedition to Siwa Oasis, Alfieri (1961) described some new sphecines (some of which are already synonyms) and Pulawski (1964) dealt with the results of his nine-month collecting stay in 1957 and 1958. Finally, in 1966 de Beaumont described four new Egyptian species and listed others not previously recorded.

Since these publications appeared, various genera have been revised on a world, or at least on a regional basis. These showed that a number of species recorded in earlier papers were incorrectly identified and in some cases several species had been lumped together under one name. In 1976 Bohart and Menke issued their monumental "Generic Revision of the Sphecidae of the World". This put the classification of the sphecids on to a sound basis but, because many groups previously regarded as subgenera were raised to full generic status, a number of nomenclatural changes became necessary. Finally, in the years since these publications, a substantial amount of collecting has taken place, often in areas considered as remote by the earlier authors, and this has turned up a number of additional species (see Gadallah 1996, 1997, 2001, 2002; Roche \& Gadallah 1999; Roche \& Zalat 1994). A full checklist is published in a companion paper (Roche 2007).

\footnotetext{
* Giles Roche was unable to complete the keys and descriptions of this magnum opus before he was force to retire because of ill health. The study is of such importance to Egyptian entomology that we publish it here in as complete a form as we have been able to make it, and encourage others to complete it. We are greatly indebted to Dr WJ Pulawski for his help in completing some section; his magnificent webbased World Catalog was invaluable. We are responsible for all remaining errors, and for the decision to publish such an incomplete work: we decided to publish because we think it will give an important impetus to Egyptian entomology, and because we believe it will enhance Giles Roche's reputation as an exceptional entomologist.
} 


\section{Key to the main groups of the Hymenoptera}

(This key is a simple one which will work on most specimens likely to be encountered, but it is not to be considered a definitive exposition for all hymenopterous insects).

1 Abdomen sessile with no constriction between the propodeum and the gaster. SYMPHYTA

- $\quad$ Abdomen with constriction between the prodeum and the gaster (APOCRITA) .... 2

2 Antennae with 14 or more segments (Evanioidea have 13 or 14 but may easily be recognised by having the abdomen attached at the top of the propodeum) "Parasitica"

- $\quad$ Antennae with 12 or 13 segments (Aculeata) .... 3

3 First, and sometimes, the second, abdominal segments strongly nodose Formicoidea

- $\quad$ First segment not strongly separated from the remainder 4

- $\quad$ Head or thorax without branched or plumose hairs; posterior metatarsus modified into cleaning mechanism (sphecid wasps) Ampulicidae, Sphecidae, Crabronidae

Acknowledgements: This paper represents an attempt to give a complete revision of the sphecid wasps that have been recorded from Egypt. The names of the species are in accordance with those given in Bohart \& Menke (1976). [Editors note: updated by Pulawski's World Catalogue, downloaded from www.calacademy.org/ research/entomology on June 16th, 2007]. The genera are listed in the same sequence as that used by Bohart \& Menke. [Editor's note: we have reorganised the order of the genera because of the recent changes in higher classification, as detailed in the World Catalog, and list them alphabetically within tribe ].

The literature has been searched and where a species has been recorded from Egypt the list gives it with its reference under the current name as well as the name used in that reference. In this way the list gives a partial synonymy, but this is effectively confined to those synonyms which affect Egypt. Synonyms which have not been used with reference to Egypt are not included. Also included are references to specimens in collections which have been examined by the author, in his own collection, that of Professor Samy Zalat and the majority of the collection of Cairo University. The records of the collections formed by Dr Alessandro Mochi and $\mathrm{Mr}$ K.M.Guichard are also included. The names under the species in the collections in Egypt are at present in many cases in doubt. Most were determined many years ago. Much taxonomic work has taken place in the intervening years which has resulted in some species being redefined or split into more than one species, or the opposite and species being synonymised. There are doubtless some misidentifications and typographical errors. In time these must be examined and where necessary the determination corrected. Descriptions and keys as far as was possible were developed from Egyptian specimens.

After the main section there is a list of the doubtful records for Egypt. Some of these are the result of misidentifications where it cannot now be established what species was being referred to, others are accidental visitors. At the end there will be found the nomina nuda and nomina dubia related to Egypt. 
Finally there will be found a list of the literature in which the references to Egypt have been found and to the sources of the original descriptions of the names cited. These papers will often be found to be of assistance in identification, although allowance must be made in many cases for the age of the papers and for subsequent discoveries.

\section{Abbreviations of institutions}

The following are the abbreviations used to denote the collections which are known to contain Egyptian material:

AM Dr. Alessandro Mochi, Rome, Italy (private collection). [On his death, Dr Mochi's collection was donated to the Museo Regionale de Scienze Naturali in Torino, Italy.]

ASUA Ain Shams University

AUCE El Azhar University, Cairo (includes coll. Alfieri).

BMNH The Natural History Museum, London, formerly the British Museum (Natural History). It contains half of A.Giordani Soika's collection - important for Eumenidae

BYS-TAUIH. Bytinski-Salz coll. (now in Zoological Museum, Tel Aviv University, Tel Aviv, Israel)

CAS California Academy of Sciences

CGR Mr. C. G. Roche, Labuan, Malaysia (private collection in Maidstone Museum, UK). [After my death the sphecids will go to the California Academy of Sciences]

CUE University of Cairo, Egypt.

DEI Deutsches Entomologisches Institut, Eberswald, Germany

EIZ Entomologisches Institut E.T.H., Zurich

ETHZ Eidgenossische Technische Hochschule-Zentrum, Zurich, Switzerland

IEEM Instituto Español de Entomologia, Madrid (includes coll. Mercet)

IMZUT Istituto della Museo di Zoologia dell'Universita di Torino, Turin, Italy

ISNB Institut Royal des Sciences Naturelles de Belgique, Brussels, Belgium

JG Dr. J. Gusenleitner, Linz, (private collection)

KMG Mr K. M. Guichard, London (now in the BMNH)

LSUK Linnean Society, London, UK

MCSNG Museo Civico di Storia Naturale di Genova, Genoa.

MHNG Muséum d'Histoire Naturelle, Geneva

MLUH Zoologisches Institut der Martin Luther Universität, Halle, Germany

MNHN Muséum National d'Histoire Naturelle, Paris.

MNMS Museo Nacional de Ciencias Naturales, Madrid, Spain

MRSN Museo Regionale di Scienze Naturale, Torino

MS Herr M. Schwarz, Linz (private collection, important for parasitic genera of bees; probably contains much Priesner material]

MSNG Museo Civico di Storia Naturale di Genova, Genova, Italy

MZCP Universidade de Coimbra, Coimbra, Portugal

MZHF Zoological Museum, Helsinki University, Helsinki, Finland

MZL Musée Zoologique, Lausanne (includes coll. de Beaumont).

MZLU Museum of Zoology, Lund University, Lund, Sweden

MZSF Université de Strasbourg, Museum Zoologique, Strasbourg, France

MZUB Museo di Zoologia dell'Università di Bologna, Bologna, Italy

MZUN Museo di Zoologia dell'Università di Napoli, Naples, Italy

NHMW Naturhistorisches Museum, Vienna (contains Kohl \& Handlirsch coll)

NMSR National Museum of Southern Rhodesia, Bulawayo (contains George Arnold coll)

NRS Naturhistoriska Riksmuseet, Stockholm (includes coll. Dahlbom)

OUM Oxford University Museum (? includes Rothney and Morice collections)

PPDD Ministry of Agriculture, Dokki, Egypt.

RMNH Nationaal Natuurhistorische Museum, Leiden, Netherlands

SAM South African Museum, Cape Town, South Africa

SMF Senckenberg Museum, Frankfurt-am-Main

SMNS Staatliches Museum für Naturkunde, Stuttgart, Germany

SZ Dr Samy Zalat, Ismailia (private collection)

TMB Termeszettudomanyi Muzeum, Budapest, Hungary

UZIU Uppsala University, Uppsala, Sweden

USNM United States National Museum (= Smithsonian Institution), Washington. (contains K. V. Krombein coll)

WJP Dr W.J.Pulawski, San Francisco (private collection, now incorporated with the California Academy of Science CAS)

ZIL Zoological Institute of the Academy of Sciences, St Petersburg

ZMHU Zoologisches Museum an der Humboldts-Universität, Berlin

ZMJU Zoological Museum, Jagiellonian University, Krakow, Poland

ZMK Zoological Museum, Copenhagen

ZMMU Zoological Museum of the Moscow University

ZSBS Zoologische Sammlung des Bayerischen Staates, Munich (? includes coll. Panzer)

ZSMC Zoologisches Staatsamlung, Munich, Germany 


\title{
AMPULICIDAE
}

\section{AMPULICINAE}

\author{
Ampulicini
}

Dolichurus Latreille, 1809

Dolichurus species may be recognized readily by the U-shaped frontal platform which covers the antennal sockets, by the filiform antennae, the long pronotum, by the presence of notauli (a pair of longitudinal grooves) on the mesonotum and by the very shining appearance. The genus occurs on all continents. Its members nest in stems and crevices and prey on cockroaches. They are usually seen running or skipping over leaf litter or on trunks of trees in search of their prey. Only one species has been recorded from Egypt.

\section{Dolichurus haemorrhous A. Costa, 1886}

Dolichurus haemorrhous A.Costa, 1886: 68-69, pl.VIII bis fig.6,, ; type in MZUN; loc. typ. Italy Ruvo di Puglia.

Egyptian synonyms: Dolichurus haemorrhous:

Pulawski, 1964: 6; Bohart \& Menke, 1976: 69.

Diagnosis (No specimens seen. Diagnosis taken from Pulawski, 1964)

Male. Colour: black, except mandibles ferruginous (except base and teeth); clypeus with a pair of decoloured yellow brown spots; antennae with scape and flagellum ferruginous beneath, darkened above, only the last 3 segments brown. Pronotum with two whitish spots laterally; tegulae dark brown, anterior part spotted with yellow. Tibiae and tarsi ferruginous with darkened patches.

Morphology: Upper part of mesopleurae punctate-rugose. Clypeus with shining median carina, anterior edge emarginate; the edges of the emargination 1.5 times further from the upper basal tubercles of the mandibles than they are from each other; the emargination contains a median tooth. T1 strongly punctate, the spaces 1-2 times as large as the punctures; T2 less strongly punctate, the spaces as large as the punctures; $\mathrm{T} 3$ even more finely punctate, the spaces smaller than the punctures; S3 elongate posteriorly, its margin convex (semi-circular) with an impression the length of the posterior margin. Length: $5.5 \mathrm{~mm}$

Female. Colour: black, except mandibles ferruginous (except teeth); clypeus with anterior part ferruginous; antennae with flagellum partly ferruginous brown; tegulae yellowish, the anterior ferruginous in part. Femora almost black, a very dark ferruginous; tibiae and tarsi light ferruginous, the tibiae darkened in part on exterior face. Abdomen red from the base or the middle of the third segment.

Morphology: Upper part of mesopleurae punctate-rugose. T1 punctate-rugose, particularly above and behind the spiracle. Length: $6.5 \mathrm{~mm}$.

Range: Italy, Portugal, Egypt

Distribution: Giza

Flight: males (12), females (11-12)

Collections: WJP

\section{SPHECIDAE}

\section{AMMOPHILINAE}

Ammophila W. Kirby, 1798

clavus species group

Ammophila barbara (Lepeletier, 1845) ssp. judaeorum Kohl, 1901

Coloptera Barbara, Lepeletier, 1845: 387, pl.31 fig.1, Ô; syntypes from Oran, Algeria (whereabouts unknown). [Kohl, 1906a; Guichard, 1988a.] 
Ammophila (Coloptera) judaeorum, Kohl, 1901c: 149, §, ᄋ; loc. typ. Palestine - Jericho (NHMW). [Kohl, 1906a; Roth, 1928.]

There is a specimen of this species taken in the Sinai in coll. Alfieri in AUCE. A new record from Egypt.

\section{Ammophila gracillima Taschenberg, 1869}

Ammophila gracillima, Taschenberg, 1869: 433, $q$; lectotype $q$ from Khartoum, Sudan (MLUH). [Kohl, 1906a; Arnold, 1928a; Guichard, 1988a.]

Egyptian synonyms:

Ammophila gracillima

Kohl, 1906a; Bohart \& Menke, 1976.

Ammophila (s.str.) gracillima

Honoré, 1942; Alfieri, 1946.

\section{Ammophila haimatosoma Kohl, 1884 ssp. haimatosoma (s.s.)}

Ammophila haimatosoma, Kohl, 1883: 383, +; loc. typ. Cyprus (NHMW). [Kohl, 1906a; Roth, 1928; Guichard, 1988a.]

Egyptian synonyms:

Ammophila (s.str.) haematosoma (sic)

Ammophila (s.str.) haimatosoma

Honoré, 1942.

Ammophila (Ammophila) haimatosoma

Alfieri, 1946.

de Beaumont, 1950c.

\section{Ammophila haimatosoma Kohl, 1884 ssp. sinaitica Alfieri, 1946}

Ammophila (s.str.) haimatosoma var. sinaitica Alfieri, 1946, + ; holotype $q$ in coll. Alfieri in AUCE; loc. typ. Egypt - Sinai, Wadi El-Ghedeirat.

Egyptian synonyms:

Ammophila (s.str.) haimatosoma var. sinaitica Alfieri, 1946.

Ammmophila haimatosoma sinaitica Bohart \& Menke, 1976.

\section{Ammophila honorei Alfieri, 1946}

Ammophila (s.str.) Honorei Alfieri, 1946: 140-141, + ; holotype $\odot$ in coll. Alfieri in AUCE; loc. typ. Egypt - Sinai, desert road between Wadi El-Arish and Hassana.

Egyptian synonyms:

Ammophila (s.str.) Honorei Alfieri, 1946.

Ammophila (s.str.) honorei de Beaumont \& Bytinski-Salz, 1955.

Ammophila honorei Bohart \& Menke, 1976.

nasuta species group

\section{Ammophila djaouak de Beaumont, 1956}

Ammophila djaouak de Beaumont, 1956a: 178-179, figs. 12-14, §̋; holotype $\widehat{\sigma}$ in coll. BMNH; loc. typ. Libya - Tripolitania (Gargaresc).

Egyptian synonyms:

The coll CUE contains one $\widehat{\partial}$ of this species, the first record from Egypt.

Diagnosis: (1 male examined.)

Male: Colour - head and thorax black, except mandibles dark ferruginous; clypeus may be red apically - only visible from beneath because of pubescence; tegulae ferruginous. Abdomen red; S1 darker; T1 dark basally and T1 \& T2 with dark mesal line not reaching the apical margins. Legs red, except tarsi 2 darker apically; fem 3 and tarsi 3 dark. Silver appressed pubescence on head, less dense on vertex, thorax, less dense on pronotum and metapleurae, and coxae. Longer white hairs scattered on head, dense on temples, a few on thorax especially on prothorax beneath. Silver pruinescence on abdomen and legs. Wings hyaline, the veins brown, red basally. Morphology - clypeus long, produced well below eye level, mesally depressed, apical margin with small distinct emargination; face narrow, at level of antennal sockets much less wide than the width of an eye; pronotum smooth and shining with fine punctures, widely spaced; mesonotum rugose with three longitudinal impressions; dorsal surface of propodeum rugose. Length: $19 \mathrm{~mm}$.

Range: Libya, Egypt

Distribution: Burg el Arab

Flight: male (8) 
Collections: CUE - first record from Egypt.

\section{Ammophila hemilauta Kohl, 1906}

Ammophila hemilauta Kohl, 1906a: 360-361, +; loc. typ. Tunisia - Medenin (NHMW). Egyptian synonyms:

Ammophila (s.str.) hemilauta Honoré, 1942; Alfieri, 1946.

Ammophila hemilauta de Beaumont, 1963a.

Diagnosis: (8 males and 9 females examined.)

Colour: head and thorax black, except red: mandibles (dark apically) apex of clypeus, apex of Ant1 below, tegulae, postero-lateral angles of propodeum. Legs $1 \& 2$ red from apex of coxae; Legs 3 coxae, trochanters and femora dark (sometimes dark ferruginous), tibiae apically dark otherwise red, tarsi dark getting ferruginous towards the apex. Abdomen red except S1 dark ferruginous, T1 basally dark above, T2 onwards with vague dark areas; $q+q$ with $\mathrm{T} 5$ mesally and T6 blue-black with metallic reflections, $\hat{\delta}$ also apically blue-black. Dense appressed silver pubescence on clypeus, frons, temples, pronotum laterally (not as dense), antero- and postero-lateral angles of mesonotum, sides and posterior of propodeum, mesopleurae and mesosternum, coxae $1,2 \& 3$, trochanters $2 \& 3$, femora $2 \& 3$. Long white hairs scattered on clypeus, frons, temples and thorax beneath, fore-femora above and below. Wings hyaline, veins brown, red-brown basally.

Male: Morphology - clypeus in profile convex basally, pre-apically depressed and concave; the apex produced and narrowed, mesally emarginate; vertex with scattered punctures; Ant3 subequal to Ant4 + Ant5. Pronotum shining with a few fine punctures; mesonotum anteriorly punctate and posteriorly transversely striate; scutellum longitudinally striate-rugose; metanotum rugose; propodeum dorsally rugose-punctate, obliquely striate laterally; metanotum coarsely punctate-rugose. One mid-tibial spur. Length: 18-21 mm.

Female: Morphology - clypeus convex in profile with mesal lobe rounded laterally and with a U-shaped mesal emargination; mandible with a large inner tooth which has a small tooth on either side of it; vertex shining with a few fine punctures. Pronotum shining with scattered fine punctures; mesonotum rather irregularly transversely striate, punctate between the striae; scutellum irregularly longitudinally striate; metanotum rugose; propodeum with the dorsal area mesally punctate-rugose, laterally obliquely striate; metapleurae coarsely punctate; sides of propodeum and mesopleurae covered with pubescence obscuring the sculpture. Fore-tarsi with a long comb on interior as well as exterior surfaces. Length: 19-21 mm.

Range: Tunisia, Libya (Tripolitania, Cyrenaica), Egypt, Jordan (Jericho)

Distribution: Burg el Arab, Mariut, Mersa Matruh, Mex

Flight: males (8), females $(6,8)$

Collections: CGR, CUE

\section{Ammophila horni Schulthess, 1927}

Ammophila horni Schulthess, 1927: 297, đ̋; holotype đ̊ in DEI; loc.typ. Port Sudan. [de Beaumont, 1963a.]

Egyptian synonyms: Ammophila horni

Range: Sudan, Egypt

Distribution: Gebel Elba

de Beaumont, 1963a.

\section{Ammophila nasuta Lepeletier, 1845 ssp. quadraticollis A.Costa, 1893}

Ammophila nasuta, Lepeletier, 1845: 380, ô, o; type from Oran, Algeria (MRSN). [Kohl, 1906a.] Ammophila quadraticollis, A. Costa, 1893a: 4 \& 1893b: 99, , (?§); loc. typ. Tunis (MZUN). [Kohl, 1906a.]

Egyptian synonyms:

Ammophila (s.str.) nasuta

Ammophila quadraticollis

Ammophila (s.str.) quadraticollis

Ammopohila nasuta quadraticollis

Diagnosis: (1 male examined.)

Male: Colour - head and thorax black, except mandibles apically dark ferruginous, tegulae ferruginous. Abdomen red, except S1 black, T1 dark basally, T2 with narrow dark basal line, T6 \& 7 and S6 \& 7 metallic blue/purple. Legs 1 and 2 red after black coxae; legs 3 dark except
Honoré, 1942. See note under next species. Kohl, 1906a.

Alfieri, 1946; de Beaumont \& Bytinski-Salz, 1955. See note under next species.

de Beaumont, 1963a. 
the basal half of the tibiae red. Silver appressed pubescence on clypeus, frons (with a slight gold tinge), temples, the anterior part of the mesonotum, the propodeum laterally, mesopleurae, mesosternum and coxae; the metapleurae are conspicuously without any silver pubescence. Longer white hairs on frons and vertex, and much longer ones on the temples. Wings hyaline, the veins dark brown, light brown basally. Morphology - clypeus very long, produced well below eye level, apically narrowly emarginate; a deep depression mesally extending almost to the apex, bounded laterally by a raised ridge, almost carinate; in profile the apex curves downwards, i.e. it is slightly convex (a subspecific character). Pronotum markedly angulate laterally; mesonotum and scutellum with a longitudinal median impressed line; dorsal surface of propodeum and metapleurae rugose. Length: $18.5 \mathrm{~mm}$

Range: Tunisia, Libya (Tripolitania, Cyrenaica), Egypt, Israel (Central, Southern - Negev).

Distribution: Alexandria (Mamaura), Kilab, Ras el Bar. Sinai - El Arish.

Flight: males $(4,8,10)$

Collections: AM, CUE

\section{Ammophila pseudonasuta Bytinski-Salz, 1955}

Ammophila (s.str.) pseudonasuta Bytinski-Salz, in de Beaumont and Bytinski-Salz, 1955: 37-38, ơ; holotype in BYS-TAUI; loc. typ. Israel - Bat Yam.

Egyptian synonyms:

$\begin{array}{ll}\text { Ammophila (s.str.) nasuta Lepeletier } & \text { Alfieri, } 1946 . \\ \text { Ammophila pseudonasuta } & \text { de Beaumont, 1963a. }\end{array}$

According to de Beaumont \& Bytinski-Salz, 1955, the figure of A. nasuta in Alfieri, 1946 refers to this species, although the text describes nasuta at least in part. This makes doubtful the records of earlier authors such as Innes, 1911, and Honoré, 1942. De Beaumont, 1963a, confirmed Alfieri's error after having seen the specimens from which the illustrations in Alfieri's paper were made by A. Mochi, sr in the collection of A. Mochi, jr.

Range: Egypt, Israel (Southern - Negev).

Distribution: Sinai - Wadi um Mitla.

\section{Ammophila strumosa Kohl, 1906}

Ammophila quadraticollis var. strumosa Kohl, 1906a: 355, q; loc. typ. Jericho (NHMW).

Egyptian synonyms:

Ammophila strumosa

Ammophila (s.str.) strumosa

de Beaumont, 1963a.

Honoré, 1942; Alfieri, 1946; de Beaumont \& Bytinski-Salz, 1955.

Diagnosis: (11 males and 15 females examined)

Colour: head and thorax black, except in $q$ mandibles sometimes very dark ferruginous and also in 9 Ant 1 sometimes dark ferruginous. Tegulae red. Legs $1 \& 2$ red from the femora onwards; in $\delta$ the apical tarsal segment of forelegs black and the tarsal segments of midlegs becoming progressively darker; hindlegs black except the basal half of the tibiae which are dark ferruginous. Abdomen: S1 black, T1 red except basally black, T2-4 red, T5 with base red, sometime the entire tergite, S2-4 or 5 red, apically blue-black with metallic reflections; all the red areas are apt to have ill-defined dark markings. Dense silver appressed pubescence on clypeus, frons (often golden), temples, pronotum (sometimes lacking and never dense except on the tubercles), anterior of the mesonotum and lateral patches posteriorly, sides and posterior of propodeum, mesopleurae, mesosternum, coxae; the lack of this pubescence on the metapleurae is very noticeable. Silver pruinosity on the trochanters, femora and tibiae. Longer white hairs scattered on the head and thorax, particularly on the temples, also on the underside of the forefemora of $q$. Wings hyaline with brown veins (red brown basally).

Male: Morphology - clypeus in profile convex at the base, the apical half slightly depressed and produced into a narrow mesal lobe truncate apically; mandibles with one inner tooth; vertex impunctate. Pronotum with marked mesal conical gibbosity, impunctate and shining; laterally there are some not very marked striae; mesonotum with mesal longitudinal depression, the posterior part transversely striate; scutellum and metanotum mesally raised with a slight median depression, the former longitudinally striate; metapleurae rugose. S7 emarginate. Midtibiae with one apical spur; pulvilli present. Length: 21-24 mm.

Female: Morphology - clypeus in profile rather convex, extended beyond the level of the eyes, apically truncate, with a pre-apical depression; mouthparts very long; mandibles with a large inner tooth which is subtended by smaller ones. Pronotum similar to that of $\hat{\delta}$; mesonotum with longitudinal depression and transversely striate; scutellum and metanotum similar to those of $\widehat{\jmath}$; 
propodeum with the dorsal area rugose, sometimes obliquely striate; metapleurae rugose. S6 slightly depressed laterally, the depressions separated by a raised area which is almost a carina. Foretarsi short and stout, the comb strong; one midtibial spur; pulvilli present. Length: 21-25 mm.

Range: Spanish Sahara, Morocco, Tunisia, Libya (Cyrenaica), Egypt, Israel (Southern - Negev), Jordan.

Distribution: Ain Sokhna road (29-43 km E of Maadi \& 50-85 km E of Maadi), Burg, Kafr Farouk, Maadi, Mersa Matruh, Suez road, Wadi Digla, Wadi Hagul, Wadi um Elek, Wadi um Assad. Sinai - Wadi um Mitla

Flight: males (4-6, 8), females $(5,8)$

Collections: CGR, CUE, PPDD

\section{other species groups}

\section{Ammophila dubia Kohl, 1901}

Ammophila dubia, Kohl, 1901c: 159, pl.7 fig. 21, §̂, o+; syntypes from 'Egypt' (NHMW), Libya (TMB) and Malta (NHMW) [Kohl, 1906a.]

Egyptian synonyms:

Ammophila dubia

Ammophila (s.str.) dubia

Kohl, 1906a; Bohart \& Menke, 1976.

Honoré, 1942; Alfieri, 1946; de Beaumont \& Bytinski-Salz, 1955.

Diagnosis: (13 males and 10 females examined.)

Colour: Black, except for the following areas. Red - mandibles (the red tends to be rather yellowish and the apex is black), anterior of Ant1 (the red is often dark ferruginous, occasionally black and the posterior surface is black), sometimes the apex of the clypeus, usually the pronotal tubercles (sometimes they are dark ferruginous), tegulae, T1-3 usually a dark line on dorsal surface, sometimes T3 \& 4 laterally, S1-2 or 3, sometimes patches on S4, legs from apex of coxae (sometimes trochanters and the base of femora 3 dark above). Remainder of abdomen blue-black with metallic reflections. Appressed silver pubescence on head and thorax, coxae and apical tergites; it is usually absent from the vertex and mesonotum. The presence of the pubescence on the apical tergites is very obvious and is a feature distinguishing dubia from poecilocnemis. Longer white hairs scattered on head and thorax, and in $q+$, on the lower side of the femora 1. Wings hyaline, the veins brown, basally light brown.

Male: Morphology - eyes convergent towards clypeus; clypeus somewhat depressed in apical half, its margin truncate, laterally rounded; vertex impunctate with a microsculpture. Pronotum impunctate with a microsculpture; mesonotum transversely striate; scutellum sometimes impunctate, sometimes longitudinally striate; dorsal area of propodeum transversely rugose. Much of the sculpture is obscured by the pubescence. Length: 13-16 mm.

Female: Morphology - eyes almost parallel; clypeus not extended below the bottom of the eyes, or only slightly so; clypeus rather flat its apex broadly rounded. Pronotum rounded, sparsely punctate; scutellum, metanotum and metanotum longitudinally striate, that on the metanotum often not distinct; dorsal area of the propodeum rugose with transverse striae; sides of propodeum and mesopleurae so covered by pubescence that the sculpture is not clear, but apparently striate. Tarsi with pulvilli. Length: $17-18 \mathrm{~mm}$.

Range: Egypt, Jordan (Jericho).

Distribution: Dakhla Oasis, Fayyum (Karanis), Gebel el Asfar, Gebel Elba (Wadi Aideb, Wadi Ganaisrob), Kafr Farouk, Kafr Hakim, Kharga Oasis, Kom Awshim (= Fayyum in Coll. Mochi; = k65 Fayyum road in Coll. CUE), Maadi, Saqqara, Tisfa. Sinai - Umm Bugma

Flight: males (1-5, 7-10), females (1-3, 5, 7, 10-11)

Collections: AM, CGR, PPDD, CUE

\section{Ammophila erminea Kohl, 1901}

Ammophila erminea, Kohl, 1901c: 156, ô, o,; syntypes from Tor, Sinai; 'Egypt' and Zeitun (said to be Malta, but actually Egypt) (NHMW). [Kohl, 1906a.]

Ammophila erminea Kohl, 1901, stat. rev., Guichard, 1988a.

Egyptian synonyms:

Ammophila erminea

Ammophila (s.str.) erminea
Kohl, 1906a; Roth, 1928; Sayed et al, 1964.

Honoré, 1942; Alfieri, 1946; de Beaumont \& Bytinski-Salz, 1955; de Beaumont, 1966. 
Diagnosis:

Colour: black, except red on the following areas - mandibles (black apically), scape (sometimes dark), tegulae, most of abdomen (last segments black and ill-defined and variable dark patches elsewhere), legs (except coxae 1-3, trochanters $2 \& 3$ black and femora 3 dark basally). Silver appressed pubescence on head, except vertex, and thorax, denser than rubripes. Longer white hairs scattered on clypeus, frons, temples, pronotum and, in $q+9$, on the underside of the trochanters 1 and femora 1; shorter hairs on remainder of the thorax. Silver pruinescence on abdomen, especially on the petiole, and legs. Wings hyaline, the veins brown, basally redbrown.

Morphology: clypeal margin more or less truncate, rounded, sometimes slightly emarginate mesally; Ant3 wider apically than basally, not parallel-sided. Mesonotum sparsely punctate, not transversely striate. 2 mid-tibial spurs; pulvilli present. Length: male 14-19 mm., female 15-19 $\mathrm{mm}$. (one example seen measuring $11 \mathrm{~mm}$ ).

Range: Spanish Sahara, Chad, Libya (Tripolitania, Fezzan, Cyrenaica), Egypt, Israel (Southern Negev).

Distribution: Abu Rawash, Abu Sultan, Abukir, Agami, 25km S of Ain Sokhna, Ain Sokhna road (29-43 km E of Maadi), Awsem, Baharia Oasis, Dakhla Oasis (Mut, Tineida), Fayyid, Fayyum ( $5 \mathrm{~km}$ E of Fayyum, Hawara Maktaa, Karanis, $5 \mathrm{~km}$ E of el Lahun, $3 \mathrm{~km}$ NW of Qasr Qarun), Gebel el Asfar, Gebel Elba (Wadi Abrag), Helwan, Ikingi Mariout, Kafr Farouk, Kerdasa, Kharga Oasis (Dush, Gineh), Kom Awshim (= Fayyum in Coll. Mochi), el Mansouria, Mersa Matruh, Nefisha, $15 \mathrm{~km} \mathrm{~S}$ of Safaga, Serapadium, Km 94 Suez road, Tanta, Tarfawi, Wadi Digla, Wadi Hagul, Wadi Hoff, Wadi Natrun, $35 \mathrm{~km}$ E of Wadi Natrun, Wadi Rishrash, Za'afarana road (40-60km E of el Korimat).

Flight: males (2-5, 7-12), females (2-12)

Collections: AM, CGR, PPDD

\section{Ammophila guichardi de Beaumont, 1956}

Ammophila (s.s.) guichardi de Beaumont, 1956a: 176-178, ㅇ, §; holotype in coll. BMNH; loc. typ. Libya - Tripolitania, Giado.

Egyptian synonyms: Ammophila (s.s.) guichardi

Range: Tunisia, Libya, Egypt, Israel.

Distribution: Wadi Digla.

Flight: males (6), females (6)

Collections:

de Beaumont, 1966.

Ammophila insignis F. Smith, 1856 ssp. egregia Mocsáry, 1881

Ammophila insignis F.Smith, 1856: 213, o; loc.typ. Gambia (OUM ro BMNH) Ammophila egregia Mocsáry, 1881: 327,,, $0^{\uparrow}$; loc. typ. Syria (i.e. Lebanon) -Beirut (TMB) [Kohl, 1906a; Arnold, 1928a; Guiglia, 1939; Guichard, 1988a.]

Egyptian synonyms:

Ammophila egregia Mocsáry Kohl, 1906a.

Ammophila (s.str.) egregia

Alfieri, 1946; de Beaumont \& Bytinski-Salz,

Diagnosis: (5 males and 3 females examined.)

Male: Colour - black, except red on the following - mandibles (dark ferruginous apically), apical margin of clypeus, Ant 1 (particularly below), sometimes also Ant3 \& Ant 4, pronotum to a greater or lesser extent, tegulae, T1-3 (T1 with a longitudinal black stripe, T3 sometimes only red laterally), S1-3 (with varying degree of black), legs (except coxae 1 black, trochanters 1 usually black but sometimes red and femora 1 basally black above; coxae, trochanters and femora $2 \& 3$ red rather dark above or black). Silver appressed pubescence on clypeus and frons between antennal sockets and eyes. Longer white hairs scattered on clypeus, frons and temples, less marked on vertex, and on anterior and ventral part of pronotum; shorter white hairs on thorax. Wings hyaline with a marked yellowish tinge, a little infuscated apically; veins yellowish-brown. Morphology - Mandibles with one large inner tooth; clypeus produced beyond level of bottom of eyes, broadly emarginate, angles of mesal lobe protuberant. Pronotum rounded with a few scattered fine punctures, laterally sometimes striate and shining; mesonotum transversely striate with punctures between; scutellum mesally rounded and metanotum longitudinally striate; propodeum dorsally transversely striate punctate between; sides of propodeum and mesopleurae densely punctate, almost rugose, mesopleurae with punctures 
below running together to form striae. Midtibiae with two apical spurs; pulvilli present. Length: 23-26 mm.

Female: Colour - black, except the following red - mandibles (black apically), apical half of clypeus, Ant 1-6; Ant 7 is much darker and the remainder black, pronotal dorsum, tubercles and sometimes laterally, tegulae, mesopleurae - a small spot beneath each tegula. Legs - coxae 1 black except at apex, coxae 3 , trochanters $3 \&$ femora 3 dark above, T1 \& T2 (T1 has a black area basally), S1 \& S2. Golden appressed pubescence faintly on frons between antennal sockets and eyes. Longer golden brown hairs scattered on clypeus, frons and temples, also but less marked on vertex and on trochanters 1 and the basal half of the fore-femora. Wings hyaline with a marked yellowish tinge, a little infuscated apically; veins yellowish-brown. Morphology mandibles with three inner teeth, the middle one being by far the largest; clypeus in profile more or less flat, its margin truncate with the lamella angular laterally. Pronotum, mesonotum, scutellum, metanotum and propodeum as $\widehat{\jmath}$; sides of propodeum and mesopleurae striate punctate between. Mid tibiae with two apical spurs; pulvilli present. Length: 31-33 mm.

Range: Chad (Tibesti), Libya (Fezzan), Egypt, Israel (Southern - Negev), Syria, Oman.

Distribution: Ain Sokhna road (29-43km E of Maadi), Gebel el Asfar, Gebel Elba (Wadi Aideb), Km 94 Suez road, Wadi Digla, Wadi Hagul, Wadi Rishrash. Sinai

Flight: males (1, 3-5), females $(4,6,11)$

Collections: AM, CGR, PPDD, CUE

\section{Ammophila mitlaensis Alfieri, 1961}

Ammophila (s.s.) mitlaensis Alfieri, 1961: 139-140, $q$; holotype $q$ in coll. Alfieri in AUCE; loc. typ. Egypt - Sinai, Wadi Mitla.

Egyptian synonyms:

Ammophila mitlaensis Alfieri, 1961; Bohart \& Menke, 1976.

Diagnosis: (one "co-type" + only examined. It is necessary to have another and more detailed examination of this specimen as there are serious discrepancies between the description below and Alfieri's original description.)

Colour: Black, except for very dark ferruginous (mandibles, tegulae and legs) and red areas (S1, T1 \& T2, base of T3, S2 \& S3 with ill-defined black areas). Silver appressed pubescence on sides of clypeus (perhaps over the entire surface if the only specimen seen is worn), frons (not reaching the anterior ocellus), pronotal tubercles, small patch on mesopleurae, posterior-lateral margins of propodeum, slight on sides of propodeum, the dorsal surface without, coxae $1,2 \& 3$. Long white hairs on temples, trochanters and femora 1 beneath. Wings slightly infuscated, the veins black or dark brown.

Morphology: clypeal margin irregularly rounded, slight mesal impression, scattered punctures; frons with longitudinal impression from interantennal area to anterior ocellus; vertex dull. Pronotum smooth and shining; mesonotum transversely striate, the striae bending back mesally; scutellum longitudinally striate; dorsal area of propodeum diagonally striate.

Range: Egypt

Distribution: Sinai - Wadi Mitla

Flight: female (5)

Collections: AUCE

\section{Ammophila poecilocnemis Morice, 1900}

Ammophila poecilocnemis Morice, 1900: 67, ふૈ, of; loc. typ. Algeria - Biskra (OUM). [Kohl, 1906a; Guichard, 1988a.]

Egyptian synonyms:

Ammophila poecilocnemis Storey, 1916.

Ammophila (s.str.) poecilocnemis Honoré, 1942.

Diagnosis: (one female examined)

Female: Colour - head and thorax black, except: middle part of mandibles, very dark ferruginous; tegulae, light red; T1-3 and S1-3 red, remainder of abdomen with blue-black metallic reflections; legs $1 \& 2$, red after dark trochanters, legs 3, basal half of tibiae red and tarsi very dark ferruginous. Silver appressed pubescence on clypeus, frons (not much above level of antennae), temples, sides of pronotum, posterior angles of mesonotum, propodeum, metapleurae $\&$ mesopleurae, coxae and trochanters; none on abdomen - not even pruinescence - which serves to distinguish this species from A. dubia. Wings hyaline, very slightly infuscated apically, veins brown, basally red-brown. Morphology - mandibles with two inner teeth; clypeus in profile convex, apically rounded, the disk punctate and shining. Pronotum rounded and sparsely 
punctate; mesonotum transversely striate; scutellum and metanotum longitudinally striate; propodeum dorsally transversely striate and rugose, laterally, the sculpture is obscured by the pubescence. Mid tibiae with two apical spurs; pulvilli present. Length: $17 \mathrm{~mm}$.

Range: Spanish Sahara, Algeria, Tunisia, Chad (Tibesti).

Distribution: Wadi Hagul.

Flight: females (6)

Collections: CGR

\section{Ammophila producticollis Morice, 1900}

Ammophila producticollis, Morice, 1900: 70, ㅇ, (nec $\widehat{\delta}=$ A. gracillima); loc. typ. Algeria - Biskra (OUM) [Kohl, 1906a; Roth, 1928; Guichard, 1988a.]

\section{Egyptian synonyms:}

Ammophila producticollis

Ammophila (s.str.) producticollis

Diagnosis: (5 males and 2 females examined.)

Colour: Because of the dense pubescence, very little can be seen of the integument beneath. Head and thorax black, except yellowish (mandibles dark at tip, labrum, apex of clypeus, Ant 1 and sometimes 2, tegulae and pronotal tubercles when visible) and red areas (abdomen - sometimes the apical tergites have ill-defined dark patches; S1 (petiole) sometimes dark, and legs - rather yellowish and sometimes the coxae and trochanters seem to be darker). Very dense and smooth silver appressed pubescence on head, thorax, petiole, coxae and trochanters. Siver pruinescence on remainder of legs and the abdomen. Some scattered longer white hairs on head (particularly on temples), prothorax beneath and femora 1.

Morphology: The whole insect has a very slender appearance. Mandibles with one inner tooth in $\overbrace{}^{\lambda}$ and two in 9 ; clypeus basally rather convex and flatter in apical half, the margin mesally a little depressed and slightly emarginate. Pronotum very long without transverse striae. Midtibiae with two apical spurs; $q$ foretarsi with apical expansions; $q$ without or with very rudimentary pulvilli. Length: male 12-15 mm., female $15-16 \mathrm{~mm}$.

Range: Algeria, Chad (Tibesti), Egypt, Israel (Southern - Negev), sw USSR.

Distribution: Gebel el Asfar, Kerdasa, Kom Awshim, Wadi Digla, Za'afarana road (90-110km E of el Korimat). Sinai - Wadi Mitla.

Flight: males (4-5), females (5-6)

Collections: AM, CGR

\section{Ammophila rubripes Spinola, 1839}

Ammophila rubripes Spinola, 1839: 465-466,, ; lectotype $q$ from 'Egypt' (MRSN) Ammophila propinqua Taschenberg, 1869: 433; $\sigma^{\lambda}$; holotype $\sigma^{\lambda}$ from Khartoum, Sudan (MLUH). [Kohl, 1906a; Arnold, 1928.]

Egyptian synonyms:

Ammophila propinqua

Ammophila rubripes

Ammophila (s.str.) propinqua

Ammophila (s.str.) rubripes

Kohl, 1906a; Roth, 1928; Arnold, 1928a.

Innes, 1911.

Honoré, 1942; Alfieri, 1946.

de Beaumont \& Bytinski-Salz, 1955; de Beaumont, 1956a, 1970

Kohl, 1906a, suspected that rubripes might be the senior synonym of propinqua and subsequent authors have so treated it.

Diagnosis: (9 males and 28 females examined.)

Colour: Head and thorax black, except the following red areas: mandibles (black at apex), clypeal apex, Ant 1 (sometimes Ant2 and even the base of Ant3), sometimes parts of the pronotum, particularly the tubercles, sometimes the posterior-lateral angles of the propodeum. Abdomen usually the first four segments are red and thereafter black, but there are usually irregular vague black areas on one or more segments. Legs red - often the coxae, trochanters \& femora 3 are dark above. Silver appressed pubescence on head and thorax, except vertex; often on the pronotum and mesonotum it is reduced; also usually on the apical abdominal tergites. Longer white hairs scattered on clypeus, frons, vertex, temples, mesosternum and femora 1. Wings hyaline, veins brown.

Morphology: mandibles with 1 tooth in $\delta$ and 2 in 9 ; clypeus moderately convex in profile and the anterior margin slightly emarginate in $\hat{\sigma}$ and rounded in $q$. Mesonotum punctate with the 
punctures running together to form transverse striae, sometimes obscured by the pubescence. Two mid-tibial spurs; pulvilli present in + . Length: male $16-19 \mathrm{~mm}$., female $18-23 \mathrm{~mm}$.

Range: Mauritania, Spanish Sahara, Morocco, Algeria, Egypt, Israel (Northern, Haifa, Tel Aviv, Southern - Negev), Chad (Tibesti), Sudan, Ethiopia.

Note: Some of the above citations are for A. propinqua Taschenberg, and if that species proves to be distinct from $A$. rubripes Spinola, then they must be suspect. It is further possible that some may be confused with $A$. erminea Kohl, as that species was also at one time placed in synonymy with $A$. rubripes Spinola.

Distribution: Abu Rawash, Abu Sultan, Abu Zabal, Burg el Arab, Dakhla Oasis, Ezbet el Nakhl, Gebel el Asfar, Gebel Elba (Wadi Aideb), Kansasrop, Kharga Oasis, Kom Awshim, Marg, Mersa Matruh, Saqqara, Serapedium, Tisfa, Wadi Hoff.

Flight: males $(3-5,10)$, females $(3-5,8,10,12)$

Collections: AM, CGR, PPDD, CUE

\section{Eremochares Gribodo, 1883}

\section{Eremochares dives (Brullé, 1833)}

Ammophila dives Brullé, 1832: 369, pl. 50, fig,10, ․ Loc. typ.: Greece (Peloponnese) (MHNH) [Kohl, 1906a; Guichard, 1988a.]

Ammophila nigritaria Walker, 1871: 18, ô,, ; syntypes from Tajoura, Djibouti (destroyed). [Kohl, 1960a.]

Egyptian synonyms:

Ammophila (Eremochares) dives Kohl, 1906a citing Walker; Roth, 1928.

Ammophila nigritaria

Ammophila (s.str.) dives

Ammophila (Eremochars) dives

Innes, 1911.

Honoré, 1942.

Diagnosis: (4 females examined)

Female: Colour - black, except the following areas are red: mandibles (black apically); apical margin of clypeus; apex of scape (very dark ferruginous); tegulae (sometimes darker); T1 (black basally); T2-3 (T3 sometimes black apically); T4 basally and laterally (sometimes lacking); T5 narrow lateral stripes (sometimes lacking); T6 laterally and apically; S1 narrowly at apex; S2-5 with basal black areas; S6; legs $1 \& 2$ - coxae dark, especially coxae 2, tarsi darker red; legs 3 very dark ferruginous but tarsi lighter. Silver appressed pubescence on clypeus, frons, pronotal tubercles, mesonotum (slight), propodeum laterally (absent on dorsal area), mesopleurae (absent on metapleurae). Long white hairs on clypeus, frons, vertex, temples, thorax (sparse). Wings hyaline, veins dark. Morphology - mandibles with large single inner tooth; clypeal margin with mesal emargination; little sculpture visible under pubescence; propodeal dorsal area diagonally striate; petiole subequal to tibia 3; mesosternum with conical protuberance anteriorly; hairs on dorsal area of propodeum leaning forwards. Length: 23-24 mm.

Range: Greece, Crete, Algeria, Libya (Tripolitania, Cyrenaica), Israel, Turkey, Arabia, Oman, sw USSR, Afghanistan

Distribution: Abu Kir, Burg el Arab, Mersa Matruh, Salloum

Flight: females (5-7)

Collections: AM, PPDD

\section{Parapsammophila Taschenberg, 1869}

\section{Parapsammophila algira (Kohl, 1901)}

Ammophila algira Kohl, 1901c: 147, pl.8 fig.46, o; loc. typ. Algeria - Biskra (NHMW). [Kohl, 1906a; Roth, 1928; de Beaumont \& Bytinski-Salz, 1955; Guichard, 1988a.]

Ammophila caelebs Kohl, 1901c: 148, ठ̊; loc. typ. Egypt - Fayum (NHMW). [Kohl, 1906a; de Beaumont \& Bytinski-Salz, 1955.]

Ammophila (Eremochares) gibba Alfieri, 1961; $\hat{0}$,, ; holotype $q$ in coll. Alfieri in AUCE; loc. typ. Egypt - Gebel Elba, Wadi Aideb. De Beaumont, 1968b, synonymized gibba with algira.

Egyptian synonyms:

Ammophila (Eremochares) caelebs

Kohl, 1906a; Alfieri, 1946: 124; de Beaumont \& Bytinski-Salz, 1955. 
Ammophila (Eremochares) algira

Ammophila (Eremochares) gibba Parapsammophila algira
Alfieri, 1946: 123; de Beaumont \& Bytinski-Salz, 1955: 35.

Alfieri, 1961.

de Beaumont, 1968b.

Diagnosis: No specimens seen

Range: Algeria, Libya (Cyrenaica), Egypt, Israel (southern - Negev), Afghanistan

Distribution: Fayyum, Sinai

\section{Parapsammophila cyanipennis (Lepeletier, 1845)}

Ammophila cyanipennis Lepeletier, 1845: 370, 9 ; holotype $q$ from Senegal (MRSN). [Kohl, 1906; Arnold, 1928a.]

Parapsammophila miles Taschenberg, 1869, §ิ,, ; lectotype $\widehat{\delta}$ in MLUH; loc. typ. (lectotype)

"Chartum", Sudan, designated by Menke, 1976. [Menke in Bohart \& Menke, 1976]

Egyptian synonyms:

Ammophila (Parapsammophila) cyanipennis Kohl, 1906a

Ammophila (Parapsammophila) cyanipennis var. miles Kohl, 1906a

Sphex (Parapsammophila) cyanipennis Arnold, 1928a.

Ammophila (s.str.) cyanipennis Honoré, 1942.

Ammophila (Parapsammophila) cyanipennis Alfieri, 1946: 121.

Diagnosis: No specimens seen

Range: N. Africa

\section{Parapsammophila dolichostoma (Kohl, 1901)}

Ammophila dolichostoma Kohl, 1901c: 146, pl.7 figs 5, $9 \&$ pl.8 fig. 38, 9 ; type $\bigcirc$ from Saudi Arabia (NHMW). [Kohl, 1906a; Guichard, 1988a..]

\section{Egyptian synonyms:}

Ammophila (s.str.) dolichostoma

Ammophila (Eremochares) dolichostoma

Parapsammophila dolichostoma
Honoré, 1942.

Alfieri, 1946: 126.

Bohart \& Menke, 1976; Guichard, 1988a.

Diagnosis: (5 males and 5 females examined.)

Males: Colour - head and thorax black except the following: clypeus yellow, except sometimes basally; mandibles yellow, except teeth (apical and inner); scape yellow; sometimes Ant3 with elongate yellow spot on inner side; pronotal tubercles sometimes orange yellow; tegulae orange yellow. Abdomen red, except for the following areas: black - petiole, dorsal part of T1, dorsal spots on T2 \& T3, T4-T7 dorsally (sometimes entirely on T5-T7), S7 (sometimes S6 \& S7); legs red, except fore- and mid-tarsomere and claws black, hind femora with black stripe on upper surface, hind tibiae with black stripe on upper surface in apical half, hind tarsi with upper surface black. Silver appressed pubescence on clypeus, frons, temples, occiput; ; on thorax it is dense but less so on mesonotum, scutellum and metanotum and absent from the dorsal area of the propodeum, dorsal part of petiole and coxae. Long white hairs scattered on clypeus, frons, temples, vertex, pronotum, anterior of mesonotum, posterior of propodeum, mesosternum from bottom of mesopleurae. Wings hyaline; veins brown. Morphology - clypeus produced beyond lower level of eyes, narrowed and apically truncate; in profile flat; mandibles with subapical tooth and marked tooth in middle of inner side; Ant3 > Ant5, wider apically; Ant11-Ant13 with tyli, particularly obvious on Ant 13; Ant13 truncate; POL > OOL; pronotum rounded; mesonotum transversely striate; scutellum rounded with median impression (not very distinct); dorsal area of propodeum glabrous and shining, finely striate, obliquely almost longitudinally in the anterior part and transversely in the posterior part; the glabrous part truncate posteriorly with a mesal v-shaped extension; mesosternum in profile with vertical anterior face at right angles to plane of main mesosternum; petiole $=$ hindtarsomeres $1+2$; R1 received by SMC2; R2 interstitial SMC2 \& 3; tarsal claws with 2 teeth; fore metatarsus nmodified at base, depression and apical spine of the tibia thickened and curved. Length: $19 \mathrm{~mm}$.

Females: Colour - head black, except the following areas: clypeus yellow; mandibles yellow, the teeth, both apical and mesal, black or sometimes only slightly darker; Ant 1-3 yellow to ferruginous, darker at apex of Ant3; Ant2 \& 3 darker above. Thorax black, except for: ferruginous stripe on pronotum, (anterior face is black); pronotal tubercles yellow-ferruginous; tegulae yellow-ferruginous; scutellar lobes with a very dark ferruginous spot or sometimes mesally entirely yellow-ferruginous; metanotum dark ferruginous mesally on anterior part. 
Abdomen red, except for: T1 with black dorsal stripe not reaching the apex; T4 and T5 black dorsally; S1 black spot at junction with T1. Legs red, except for: claws of fore and mid legs dark; coxae 3 and trochanters 3 black above; femora 3 with a dark stripe above; tibiae 3 apically dark above; tarsi 3 with tarsomere 1 and 5 dark above and claws dark. Silver appressed pubescence, in general less dense than in male: on clypeus, especially basally and laterally; frons; temples below; pronotum, the anterior surface; mesonotum, only the posterolateral angles; propodeum except the dorsal area; mesopleurae; coxae and trochanters 3 above. Scattered long white hairs on clypeus, temples, pronotum below, underside of femora 1. Wings hyaline; veins brown. Morphology: clypeus truncate, in profile somewhat rounded; mandibles with 2 subapical teeth, the second much smaller, and one marked mesal tooth; Ant3 > Ant5, wider apically; POL $>$ or $=\mathrm{OOL}$; pronotum rounded, impunctate and shining; mesonotum transversely striate, the striae curved forward from the mesal line, then back again, i.e. bowed forwards - sometimes the striae are less marked or even obsolete near the scutellum (in one example examined the striation was only in the anterior part of the mesonotum, the posterior part being shining with a few scattered punctures); scutellum with a mesal impression, i.e. slightly bilobate, impunctate; metanotum rounded and impunctate; dorsal area of propodeum striate, obliquely in the anterior part and almost transversely in the posterior part; dorsal area is truncate as in the male; sides of thorax invisible beneath the pubescence; mesosternum transversely striate, punctate between striae, sometimes almost rugose; mid-tibiae with 2 apical spurs; fore tarsi with comb, the metatarsus being apically extended; base of foretarsus and tibial apex modified as in the male; petiole $=$ hind tarsomeres $1+2$; R1 in SMC2; R2 interstitial SMC2 \& 3 or in SMC2. Length: 22-25 mm.

Range: Egypt, Israel (Northern, Jerusalem, southern - Negev), Syria, Turkey, Aden, Saudi Arabia

Distribution: Abu Rawash, Ain Sokhna road 50-85km E of Maadi, Gebel Elba, Wadi Digla, Wadi Hagul. Sinai - Wadi Mitla

Flight: males $(2,5-6,8)$, females (3-7)

Collections: AM, CGR

\section{Parapsammophila lateritia Taschenberg, 1869}

Parapsammophila lateritia Taschenberg, 1869: 431, +; loc. typ. Sudan - Khartum (MLUH). [Kohl, 1906a; Guichard, 1988a.]

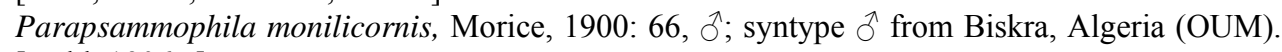
[Kohl, 1906a.]

Egyptian synonyms:

Ammophila (Parapsammophila) lateritia Kohl, 1906a, but with doubt as to whether it does occur in Egypt; Roth, 1928; Alfieri, 1946: 121.

Parapsammophila monilicornis var. Storey, 1916.

Ammophila (s.str.) lateritia Honoré, 1942.

Ammophila (Parapsammophila) monilicornis var. Roth, 1928 (citing Storey, 1916).

Diagnosis: No specimens seen

Range: Algeria, n. Africa

\section{Parapsammophila turanica F. Morawitz, 1890}

Parapsammophila turanica F. Morawitz, 1890: 582, ڤึ; holotype đે from Turkmenistan (ZIL). [Kohl, 1906a; Guichard, 1988a.]

Parapsammophila lutea auctt, nec Taschenberg, 1869. [Menke, 1966.]

Egyptian synonyms:

Ammophila (Eremochares) lutea

Ammophila (s.str.) lutea

Eremochares lutea

Kohl, 1906a; Roth, 1928; Alfieri, 1946: 123; de Beaumont \& Bytinski-Salz, 1955: 35; de Beaumont, 1958d: 56.

Storey, 1916; Honoré, 1942.

Pulawski, 1964: 65. It was not until Menke, 1966, that the true identity of lutea was established. It is confined to the Sudan.

Diagnosis: (20 males and 21 females examined.)

Males: Colour - black, except the following red: mandibles (yellowish red), except black apex; apical margin of clypeus; scape apical yellowish red spot (sometimes lacking); underside of Ant9-Ant13 (sometimes); tegulae (yellowish sometimes); T1 dorsally apically and laterally from the start of the swollen part; T2-7, but sometimes T6-T7 with basal mesal spot or completely 
black mesally, T7 also black apically or completely; in dark specimens most tergites invaded by black markings; most specimens in Coll PPDD have T5-T7 black dorsally; S1 apically; S2-S7, but with black spots on any or all; legs from apex of coxae; sometimes black on upper surface of trochanters and femora. Silver appressed pubescence on: head - clypeus, frons, temples; thorax pronotum, mesonotum laterally, scutellum laterally, sides of propodeum, metapleurae, mesopleurae, mesosternum, coxae; petiole, at least the base. Long white hairs on head except the clypeus, dense on the thorax, but short on mesonotum, scutellum and metanotum. Antennae covered with pruinesence except the red areas on Ant9 - Ant13. Wings hyaline; veins yellow brown. Morphology - mandibles with subapical tooth and a large mesal one; clypeus flat, depressed basally and raised apically, apex rounded, sometimes a little sinuate; Ant3 > Ant5; no tyli (?); Ant 13 truncate; POL > OOL; mesonotum punctate; scutellum rounded, with a slight mesal impression; propodeum mesally rugose, finely transversely striate, laterally more coarsely striate; R1 received in SMC2; R2 interstitial SMC2 \& 3 or in SMC2; anterior basitarsus and tibial spur modified (as in P. dolichostoma), the basitarsi depressed basally and with a distinct pecten; mid tibiae with 1 stout and curved apical spur; tarsal claws with 2 teeth, but one is indistinct. Length: 18-22 mm.

Females: Colour - head often much obscured by pubescence; mandibles red, black apically; clypeus red; Ant1 red; Ant 2 and base of Ant 3 red, black or dark ferruginous; remainder very dark ferruginous or black; vertex black. Thorax often much obscured by pubescence; pronotal tubercles seen through the pubescence seem to be red; tegulae red; mesonotum, scutellum, metanotum and propodeum black. Abdomen: T1 dark at base, then red; T2-6 red, sometimes T4-6 are dark at base mesally; S1 (petiole) black, red apically; S2-6 red, but S2-4 sometimes with dark basal spots; legs entirely red, the tarsal claws black or dark ferruginous. Dense silver appressed pubescence on head and thorax, coxae and petiole obscuring much of the sculpture and colour of the integument; this pubescence may be lacking on the mesonotum mesally, and laterally on the dorsal area of the propodeum. Longer white erect hairs on the clypeus, temples, frons, vertex, pronotum and the underside of the fore-femora; anteriorly on the mesonotum there are some long white decumbent hairs directed posteriorly. Wings hyaline; veins light brown, basally more yellow-brown and darker around the marginal cell. Morphology mandibles with a large inner tooth which has a small tooth on either side of it (sometimes these are very reduced or absent); clypeus in profile a little swollen, the margin at a depressed level; usually the sculpture of the disk can be seen to comprise scattered punctures; there seem to be two forms of the clypeal apex: (i) sinuate and not particularly convex with projections at the sides of the mesal part; (ii) distinctly convex and not sinuate and without lateral projections, the mesal part almost blending into the lateral parts - this form could be due to the apical lamina which forms the sinuate part and the projections being worn. Ant3 a little wider apically than basally, in length subequal to or a little less than Ant4+5; POL $=$ OOL; mesonotum smooth and shining posteriorly with one or two punctures, and with a longitudinal median depression; anteriorly the sculpture is much obscured but sometimes seems to be laterally striate; scutellum with a slight median impression; propodeum with a mesal longitudinal line with transverse or somewhat oblique fine striae from it; sides seem to be more roughly striate; mesosternum not particularly angled between anterior and ventral surfaces; petiole shorter than or subequal to hind tibiae; anterior metarsus strongly produced externally into a finger-like process bearing 4 stout hairs; tarsomeres 2 - 4 somewhat enlarged externally apically all with long fine comb-hairs, the hairs on the enlarged processes are stouter; one mid-tibial spur; tarsal claws with two teeth; R1 received in SMC2; R2 in SMC2 or interstitial. Length: 22-26 mm.

Range: Spanish Morocco, Algeria, Libya (Fezzan), Egypt, Israel, (southern - Negev), Iran, sw USSR. Note: because many authors used the name Eremochares lutea Taschenberg in error for this species, it is possible that some of the above range could apply to the true E. lutea which was described by Taschenberg from the Sudan.

Distribution: Abu Rawash, Abydos, Ain Sokhna road (29-43 km E of Maadi), Cairo (environs), Dakhla Oasis (Mut), Fayyum, Kerdasa, Kom Awshim ( = Fayyum in Coll. Mochi), Tell el Amarna, Wadi Assiouti, Wadi Digla, Wadi T.Rachid, Za'afarana road $101 \mathrm{~km}$ E of El Korimat. Sinai - Hamamat Faraoun, Wadi Gharandal

Flight: males (3-6), females (3-6)

Collections: AM, CGR, PPDD, WJP, CUE 
Podalonia Fernald, 1927

affinis species group

Species of this group have in common the propodeum finely striate and glabrous.

Podalonia affinis (W. Kirby, 1798) ssp. affinis (s.s.)

Ammophila affinis, Kirby, 1798: 205, ô, O; loc. typ. England - Woodbridge (whereabouts unknown). [Kohl, 1906a; Guiglia, 1939; Guichard, 1988a.]

\section{Egyptian synonyms:}

Ammophila (Podalonia) affinis Alfieri, 1946: 119.

Diagnosis: (1 males and 2 females seen.)

Males: Colour - black, except tegulae, tergites, and legs beneath, very dark ferruginous; silver appressed pubescence on clypeus, frons laterally, anterior of coxae 1; longer dark hairs on clypeus, frons, vertex, temples (very long), pronotum, mesonotum, scutellum and metanotum (shorter), propodeum except the dorsal surface (very long), mesopleurae, metasternum. Wings hyaline, rather infuscated apically, the veins light brown. Morphology - clypeal margin mesally truncate, rounded to lateral lobes; vertex sparsely punctate over microsculpture; pronotum punctate, the punctures running together; mesonotum punctate; scutellum rounded, longitudinally striate; metanotum irregularly sculptured; propodeum dorsally irregularly striate, punctate between the striae, which are transverse anteriorly and oblique behind, laterally rugose-striate; mesopleurae rugose. Length: $15 \mathrm{~mm}$.

Females: Colour - black, except the following are red: apex of mandibles (very dark); T1, T2, T3 (dark apically); apex of S1, S2 (dark mesal spots), S3 basally; legs (very dark). Pubescence dark or black. Wings yellowish, the veins light brown. Morphology - mandibles with inner tooth; clypeal margin mesally with shallow very broad emargination, almost sinuous; mesal area raised above the level of the apical margin and lateral areas; punctate, the apical margin impunctate, shining; frons punctate, the punctures below large and more spaced, finer and denser above; vertex, behind ocelli, with only scattered punctures; pronotum somewhat "humped" dorsally, punctate dorsally and striate laterally; mesonotum finely punctate, posteriorly the punctures running together to form longitudinal striae; scutellum punctate, mesally with one or two longitudinal striae; metanotum short and rugose; propodeum with the dorsal area finely striate, the striae transverse, but anteriorly bending forwards mesally, laterally coarsely striate; mesopleurae rugose; legs 1 with the tarsomeres produced apically, especially the metatarsi; tarsal comb of thick black spines and three stout spines on the apical process of the metatarsi; the metatarsi with outer margin with three saw-like projections before the apical process, carrying the stout hairs of the comb; forewings with both recurrent veins received in SMC2; abscissae of radial vein variable, sometimes SMC2 is wider than SMC1 or SMC3 on the radial, sometimes $\mathrm{SMC1}$ is wider than the others. Length: $17-18 \mathrm{~mm}$.

Range: UK (England), Algeria, Libya (Fezzan), Egypt, Israel (southern - Negev), Syria, Turkey

Distribution: Abu Rawash, Ein Shams

Flight: males (3), females (3)

Collections: PPDD, CUE

Podalonia atrocyanea (Eversmann, 1849) ssp. masinissa (Morice, 1900)

Psammophila atrocyanea Eversmann, 1849: 365,, ; loc. typ. Russia - Urals, Orenburg (ZIL) Psammophila masinissa Morice: 65, + ; syntype + from Biskra, Algeria in OUM

Egyptian synonyms:

Ammophila (Psammophila) atrocyanea $\quad$ Kohl, 1906a; Honoré, 1942.

Ammophila atrocyanea

Ammophila (Podalonia) atrocyanea
Storey, 1916 (but see note).

Alfieri, 1946: 112; de Beaumont \& Bytinski-Salz, 1955: 33; de Beaumont 1960a: 224.

Ammophila (Psammophila) atrocyanea masinissa Honoré, 1942.

Ammophila (Podalonia) atrocyanea var. masinissa Alfieri, 1946.

Ammophila (Podalonia) atrocyanea v. massinissa (sic) de Beaumont \& Bytinski-Salz, 1955:

33.

Ammophila (Podalonia) masinissa Morice de Beaumont, 1960a: 224

Roth, 1928, quotes Storey as saying this species occurs in Egypt but he is not sure whether Storey is referring to this species or to masinissa. Kohl, 1906a, treated masinissa as a synonym 
of P. atrocyanea. Honoré, 1942, Alfieri, 1946, and de Beaumont \& Bytinski-Salz, 1955, all treated masinissa as a variety of atrocyanea. [Editors note: we have assumed here that all specimens recorded from Egypt belong to this ssp]

Range: [S.Europe, Egypt, USSR, C.Asia, N.China = the species]. Spanish Sahara, Algeria, Libya (Tripolitania, Cyrenaica), Egypt (Sinai), Israel (southern - Negev)

\section{Podalonia ebenina (Spinola, 1839)}

Ammophila ebenina Spinola, 1839: 464-465, + ; lectotype $q$ from 'Egypt' (MRSN). Ammophila (Psammophila) micipsa Morice, 1900: 66, + ; syntype + from Biskra, Algeria (OUM). [Kohl, 1906a.]

\section{Egyptian synonyms:}

Ammophila (Psammophila) micipsa Kohl, 1906a; Honoré, 1942.

Ammophila hirsuta var. mervensis Radoszkowski, $1887 \quad$ Kohl, 1906a.

Ammophila ebenina Innes, 1911.

Ammophila hirsuta Scopoli, $1763 \quad$ Storey, 1916.

Ammophila (Psammophila) ebenina Roth, 1928.

Ammophila (Podalonia) micipsa Alfieri, 1946: 113.

Ammophila (Podalonia) ebenina Alfieri, 1946: 120; de Beaumont, 1967b: 263.

Ammophila (s.s.) (lapsus) ebenina de Beaumont, 1954c: 2.

Spinola's ebenina was for long not recognised, although Kohl, 1906a, listed it with a query under P. micipsa. He also regarded ebenina Costa, nec Spinola, as a synonym of mervensis. Various authors assumed that the black subspecies of Podalonia hirsuta was the missing ebenina, eg Alfieri, 1946, but in fact P. hirsuta mervensis Radoszkowky is confined to the Mediterranean islands and central Asia; also ebenina and hirsuta belong to different species groups. Kohl, 1906a, put ebenina with a question mark as a synonym of Ammophila (Psammophila) micipsa Morice. He also refers to "var. Mervensis Rad. = ebenina Costa non Spin."; his description makes it clear that it belongs to the hirsuta group and not to the affinis group. There are no reliable records of hirsuta occurring in Egypt.

Diagnosis: (4 females examined.)

Female: Colour - black, except the following areas are dark red: mandibles (in part); sometimes the clypeus; sometimes the frons laterally between the antennal sockets and the eyes; sometimes the pronotum; tegulae; sometimes the mesopleurae; legs; part of T1. Wings infuscated, the veins brown excecpt the subcosta which is black; in one example seen, the wings are not fully infuscated. Morphology - mandibles with inner tooth and a second smaller one behind the first; clypeal margin mesally with shallow very broad emargination, almost sinuous; mesal area raised above the level of the apical margin and lateral areas; punctate, the apical margin impunctate, shining; frons punctate, the punctures below large and more spaced, finer and denser above; vertex, behind ocelli, with only scattered punctures; pronotum less humped than in affinis, the lateral striae coarser; mesonotum with punctures more spaced than in affinis, posteriorly almost impunctate, shining; scutellum almost impunctate, shining; propodeum transversely striate dorsally, laterally striate, rugose between the striae; legs 1 as in affinis but 4 stout hairs arising from the apical process of the metatarsi, the tarsal comb thicker; petiole subequal to the hind metatarsus. Length: 16-18 mm.

Range: Canary Is., Libya (Tripolitania), Egypt, Jordan (Jericho), Syria, sw USSR (Caucasus, Turkestan)

Distribution: Burg el Arab, Gebel el Asfar, Kom Awshim (= Fayyum in Coll. Mochi), Kafr Farouk. Sinai - Wadi Mitla

Flight: males (2), females (2-5)

Collections: AM, CGR, CUE

\section{Podalonia minax (Kohl, 1901)}

Ammophila (Psammophila) minax, Kohl, 1901c: 162, $q$; holotype $q$ from Egypt - Abbasieh nr. Cairo (NHMW). [Kohl, 1906a; Guichard, 1988a.]

Egyptian synonyms: Ammophila (Psammophila) minax Ammophila (Podalonia) minax

Diagnosis: (2 females examined.)
Kohl, 1906a; Honoré, 1942.

Alfieri, 1946: 117; de Beaumont, 1950a: 395; Pulawski, 1964: 65; Bohart \& Menke, 1976. 
Female: Colour - black, except for the following areas: mandibles sometimes very dark ferruginous in the middle; labrum red; tegulae light ferruginous; T1-3 and sometimes base of T4 red; S2-3 and sometimes S1 and the base of S4 red; legs 1 with trochanters sometimes reddish beneath, femora red from the base or from the middle, tibiae and tarsi red, tarsal comb black; legs 2 red from apex of femora beneath from about middle (in one example), or red at the apex of femora and tibiae only (other); legs 3 apex of femora and basal half of tibiae red and tarsi dark ferruginous (one example), or entirely dark (other). Silver appressed pubescence laterally on the base of clypeus and on frons between the antennal sockets and inner orbits. Long white hairs sparse on temples and on sides of propodeum, rather shorter ones on dorsal surface of thorax and posterior surface of propodeum. Silver pruinescence on vertex and posterior segments of abdomen. Wings hyaline, apices of forewings distinctly infuscated, hindwing apices only slightly darkened; veins brown, yellow basally, costa and subcosta yellow completely. Morphology - clypeus with the mesal lobe broadly rounded, dentate laterally, shining with a few scattered punctures; frons with a longitudinal depressed line from anterior ocellus to interantennal area, with microsculpture and a line of punctures along eye margin; Ant 3 almost = Ant 4+5; POL < OOL; pronotum, mesonotum and scutellum smooth and shining; scutellum rounded; metanotum mesally raised but rounded; propodeum with the dorsal very finely and evenly transversely striate, laterally striate but much less finely and less evenly; mesopleurae striate similarly to the sides of the propodeum. Length: $11-12 \mathrm{~mm}$.

Range: Spanish Sahara, Algeria. Libya (Tripolitania, Fezzan, Cyrenaica), Egypt

Distribution: Abu Rawash, Ain Sokhna road (29-43 km E of Maadi), Cairo (environs), Gebel el Asfar, Saqqara, Tell el Amarna

Flight: males (3-5), females (2-5)

Collections: AM, CGR, WJP

hirsuta species group

Species of this group have in common the propodeum rugose and covered with pubescence.

\section{Podalonia dispar (Taschenberg, 1869)}

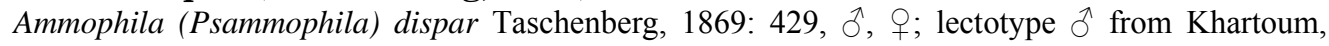
Sudan (MLUH). [Kohl, 1906a.]

Egyptian synonyms:

Ammophila (Psammophila) dispar Kohl, 1906a; Honoré, 1942.

Ammophila (Podalonia) dispar Alfieri, 1946: 118.

Podalonia dispar Pulawski, 1964: 65; Bohart \& Menke, 1976.

Diagnosis: (12 males and 15 females examined.)

Males: Colour - Black, except for dark ferruginous (mandibles except dark apex; tegulae; tarsal claws; in one example seen, hind tarsi) and red areas (T1-3; base of T4; S1 after the petiole, S2-3 and base of S4). Silver appressed pubescence on clypeus; frons; mesopleurae without a silver patch (distinct from tydei), at most a little ventrally and around coxae. Long white hairs on head and thorax, particularly long and dense on temples; on sides of propodeum (these are mixed with darker hairs, as distinct from tydei). Wings hyaline, slightly infuscated apically, the veins dark, the pterostigma sometimes a light brown in contrast, the costa and subcosta lighter brown basally. Morphology - sculpture of clypeus and frons obscured by pubescence; vertex punctate to varying degree, more spaced near ocelli; POL subequal to OOL; mesonotum punctate shining between; scutellum shining, punctate but posteriorly sometimes with longitudinal striae, with mesal impression; dorsal area rugose, laterally almost striate with punctures between; mesopleurae rugose; petiole shorter than hindtibia. Venation very variable: usually SMC3 on media = distance between the two recurrent veins on the media; in one example seen SMC2 was triangular. Length: 10-15 mm.

Females: Colour - black, except for dark ferruginous (spot in middle of mandibles; tegulae; tarsal claws; sometimes tarsomeres 4 \& 5) and red areas (T1-3; base of T4; S1 after petiole; S2-3; base of S4); often there are indefinite black areas on the sternites. One example seen with legs entirely red. Silver appressed pubescence on clypeus; frons laterally (not between the antennae); coxae and trochanters $2 \& 3$, the longer hairs black. Longer hairs on head and thorax black, but mixed black and white on the sides of the propodeum, white posteriorly on the propodeum. Tibiae and to a lesser extent tarsi with silver pruinescence. Wings as male. Morphology - from front view the vertex is flat, not particularly convex; clypeus punctate with the apical margin 
sinuate; frons densely punctate but more finely than on the clypeus; POL subequal to OOL; thorax densely punctate, sometimes the mesonotum is almost impunctate posterioly, the scutellum longitudinally striate posteriorly; metanotum rounded; propodeum rugose with a tendency to form vague striae; petiole shorter than metatarsi 3, a little longer than tarsomere 2; pulvilli very small but present. Length: $15-18 \mathrm{~mm}$.

Range: Sudan, Libya (Tripolitania), Egypt

Distribution: Baharia Oasis, Cairo (environs), Dakhla Oasis, Fayyum (5 km e of El Fayyum, Hawara, Karanis, Kom el Atl), Gebel el Asfar, Helwan, Kerdasa, Kom Awshim (= Fayyum in Coll. Mochi), Luxor, Wadi Digla. Sinai - Feiran

Flight: males $(1-5,7,10)$, females $(1-5,10-12)$

Collections: CGR, CUE, WJP

\section{Podalonia marismortui (Bytinski-Salz, 1955)}

Ammophila (Podalonia) maris-mortui Bytinski-Salz in de Beaumont and Bytinski-Salz, 1955: 3335, ô, o; type in BYS-TAUI; loc. typ. Israel - Old Jericho Road.

Egyptian synonyms:

Ammophila (Podalonia) marismortui de Beaumont, 1966.

Ammophila (Podalonia) maris mortui (sic) de Beaumont, 1968b.

Diagnosis: (2 females examined)

Female: Colour - black, except dark ferruginous on: mandibles, dark apically; tegulae; legs, especially hind legs. Pubescence of head and thorax entirely black, shorter and very much less dense than in schmiedeknechti, absent from mesonotum, scutellum and metanotum. Wings uniformly infuscated, except the base of the hindwing a little paler, veins dark. Morphology mandibles with a large inner tooth with a much smaller one behind it; clypeal margin with a trilobate lamina; clypeus and frons densely punctate over microsculpture; vertex with only scattered punctures; pronotum dorsally punctate, laterally striate; mesonotum with a longitudinal impression in the anterior half; punctate with rather fine punctures, posteriorly the punctures are much more spaced leaving smooth shining areas between; scutellum anteriorly punctate, longitudinally striate posteriorly; metanotum punctate; propodeum rugose dorsally, laterally rugose tending to become striate; mesopleurae densely punctate almost rugose; petiole subequal to hind tarsomere 1; metatarsi 1 with comb of 3 spines from the apical expansion and 5 others. Length: 16-17 mm.

Range: Mediterranean region, Israel, Egypt, Iraq

Distribution: Sinai - Wadi El Arbain

Flight:

Collections: CUE

\section{Podalonia schmiedeknechtii (Kohl, 1898)}

Ammophila (Psammophila) Schmiedeknechtii Kohl, 1898: 340, + ; loc. typ. Egypt - Wadi Hoff (TMB). [Kohl, 1906a.]

Egyptian synonyms:

Ammophila (Psammophila) Schmiedeknechtii Kohl, 1906a, Honoré, 1942.

Ammophila (Podalonia) Schmiedeknechti Alfieri, 1946: 115.

Podalonia schmiedeknechtii

Diagnosis: (6 males and 8 females examined.)

Male: Colour - black, except very dark ferruginous on apex of mandibles, tegulae and tarsal claws; silver appressed pubescence on clypeus; long black hairs on head and thorax; silver pruinescence on legs and T1-5; wings slightly infuscate, markedly so apically, the veins dark brown, the costa sometimes yellow-brown. Morphology - clypeus with margin of mesal lobe truncate or, more usually, broadly emarginate (because of the pubescence, only seen from below between opened mandibles); Ant1 subequal to Ant4; mesonotum coarsely punctate with tendency for the punctures to join into longitudinal striae; scutellum punctate or longitudinally striate; propodeum dorsally and laterally rugose; petiole subequal to hind metatarsus. Length: 9$13 \mathrm{~mm}$.

Female: Colour - black, except dark ferruginous on mandibles (sometimes), tegulae (sometimes) and legs, especially hindlegs (sometimes); pubescence of head and thorax entirely black, long and dense, less on mesonotum, scutellum and metanotum; wings uniformly infuscate, except the base of the hindwing a little paler, the veins dark. Morphology - mandibles with large inner tooth 
with a much smaller one behind it; clypeal margin with lamina which is uniformly convex; clypeus and frons densely punctate over microsculpture; vertex with only scattered punctures; pronotum dorsally punctate, laterally striate; mesonotum rather coarsely punctate, posteriorly the punctures much more spaced leaving smooth shining areas between; scutellum punctate anteriorly, longitudinally striate posteriorly; metanotum punctate; propodeum rugose dorsally, laterally rugose tending to become striate; mesopleurae densely punctate almost rugose; petiole $>$ hind tarsomere $2,<$ hind tarsomere 1; fore-metatarsus with comb of 3 spines from apical expansion and 5 others. Length: 14-17 mm.

Range: Libya (Tripolitania, Fezzan), Egypt

Distribution: Abu Rawash, Cairo (environs), Ezbet el Nakhl, Gebel el Asfar, Giza, Ikingi Mariout, Kafr Farouk, Km 54 \& 55 Cairo-Suez Road, Tell el Amarna, Wadi Assiuti, Wadi Digla. Sinai Wadi Mitla

Flight: males (2-3, 7, 11), females (2-5)

Collections: AM, CGR, CUE, WJP

Podalonia tydei (Le Guillou, 1841) ssp. argentata Lepeletier, 1845

Ammophila Tydei Le Guillou, 1841: 319-320, o; loc. typ. Teneriffe (?MNHN). Ammophila argentata Lepeletier, 1845: 366, + ; holotype + from Oran, Algeria (whereabouts unknown). [Kohl, 1906a.]

Egyptian synonyms:

Ammophila argentata Br.(sic) Innes, 1911.

Ammophila tydei

Ammophila (Psammophila) Tydei

Storey, 1916; Sayed et al, 1964.

Ammophila (Podalonia) Tydei

Kohl, 1906; Honoré, 1942.

Podalonia tydei

Alfieri, 1946: 117; de Beaumont, 1950c.

Sphex tydei (sic)

Pulawski, 1964: 65.

Sayed et al, 1964

Diagnosis: (41 males and 100 females examined.)

Male: Colour - black, except some red (T1, T2, T3 with apical black spot sometimes and the base of T4 laterally; S1 from the apex of the petiole, S2, S3 and the base of S4) and dark ferruginous areas (mandibles in the middle; tegulae; legs, getting a little lighter ferruginous apically, sometimes almost black). Silver appressed pubescence on clypeus and frons laterally, sometimes on the pronotum, a patch on the mesopleurae, the sides of the propodeum, sometimes the mesosternum, coxae. Long white hairs all over head and thorax, sparse on vertex, shorter on mesonotum, scutellum, metanotum and basal part of dorsal area of propodeum, often long on base of petiole, femora with scattered long white hairs beneath. Silver pruinescence on legs and abdomen. Wings subhyaline slightly infuscated apically, veins brown, slightly lighter basally as is the costa entirely. Morphology - clypeus with its apical margin mesally broadly but slightly emarginate, with a microsculpture but no coarse sculpture; mandibles with a pronounced inner tooth; POL < OOL; vertex with scattered punctures, spaces greater than punctures especially near ocelli; mesonotum with spaced punctures, shining between punctures; scutellum punctate and posteriorly longitudinally striate; propodeum rugose, sometimes the rugosities flowing together to form indefinite transverse striae; petiole rather longer than metatarsi 3. Length: 10.5$18 \mathrm{~mm}$.

Female: Colour - black, except some dark ferruginous (middle of mandibles, the apex black; tegulae; sometimes the tarsi) and red areas (T1 to base of $\mathrm{T} 4$ or $\mathrm{T} 1-4$, sometimes also $\mathrm{T} 5$ laterally; S1 from mid-petiole to base of S4; sometimes to base of S5). Silver appressed pubescence on: clypeus, not extending to the apical margin; frons, laterally not mesally between the antennae; mesopleurae, at least a mesal patch; sides of propodeum; base of petiole. Long white hairs on head and thorax; those on the vertex shorter and less dense; those on the mesonotum shorter; more or less absent from posterior part of mesonotum, scutellum and metanotum. Coxae 1-3 have long hairs as do femora 1 beneath; these usually white but sometimes dark mixed with white. Wings subhyaline, veins brown, basally yellowish brown. Morphology - head in front view wide; mandibles with a strong inner tooth with a small one behind it; apex of clypeus sinuate and slightly emarginate mesally; mesal lobe separated from the lateral ones by a notch, the corners of the mesal lobe angulate; apical part of the clypeus punctate; POL < OOL; vertex in front view not very rounded, punctate with spaces larger than punctures especially near ocelli; pronotum sometimes laterally striate; mesonotum punctate, posteriorly punctures are sparse and surface smooth and shining; scutellum impunctate or 
sparsely punctate anteriorly, posteriorly striate longitudinally; propodeum rugose; metapleurae striate above; mesosternum punctate; petiole $>$ metatarsus 3; metatarsi 1 with 6 or 7 comb spines, including 3 terminal ones; anterior tarsomeres apically produced; pulvilli distinct but small. Length:

Range: Morocco, Algeria, Libya (Tripolitania, Fezzan, Cyrenaica), Egypt, Israel, Syria, Turkey, Chad (Tibesti), tropical Africa to Cape, Madagascar, Oman, Iran, USSR (Turkestan)

Five subspecies are currently recognized: tydei - Canary Is., Madeira Is.; senilis - s. Europe, Asia; argentata - n. Africa; suspiciosa - Australia; apakensis - China. Presumably, the Egyptian representatives are argentata. The literature often does not distinguish between the subspecies and therefore the range of argentata given may include that of some other subspecies.

Distribution: Abu Rawash, Abu Sir, Ain Sokhna road (29-43km E of Maadi), Alexandria, Bir el Manayit (nr. Ismailia), Burg el Arab, $30 \mathrm{~km}$ nw of Cairo, Cairo - Alexandria desert road 60km S of Alexandria, Damietta, Fayyid, Fayyum (Karanis), Gebel el Asfar, Gebel Elba (Wadi Ga.. Isrob, Wadi Aidab, Wadi Hekwal), Giza (Pyramids), Helwan, Ikingi Mariout, Ismailia, Kafr Farouk, Kafr Hakim, Kerdasa, Kharga Oasis (el Kharga), Kom Awshim (=Fayyum in Coll. Mochi), Mersa Matruh, el Minia, Sidi Abdel Rahman, Tahrir, Tell el Amarna, Tell el Kebir, 10th Ramadan City, Wadi Hagul, Wadi el Natrun (Deir Abu Magar), 35km E of Wadi Natrun, Warra' el Arab

Flight: males (1-12), females (2-10, 12)

Collections: AM, CGR, PPDD, WJP, SZ

\section{Podalonia sp.}

The coll. Alfieri in AUCE contains an undescribed species of Podalonia with a MS name purporting to be a species described by Mochi. The description was never published. I do not mention the manuscript name on the label as I do not wish to create a nomen nudum.

\section{Diagnosis:}

Male: Colour - black except there are yellowish-red areas (mandibles dark ferruginous apically; tegulae; legs $1 \& 2$ from the trochanters, the coxae are red apically; legs 3 from mid-femora, the apex of the tibiae darker) and red areas (S1; T1, dorsally with a longitudinal black marking; T2, in the basal half dorsally a longitudinal black stripe; T3, a black dorsal basal spot; T4, red only laterally; S2-4; S5 basally only). Silver appressed pubescence on: clypeus; frons laterally (i.e. between antennal sockets and the eyes) not reaching the anterior ocellus; temples; sides of the pronotum including the tubercles; antero-lateral corners of the mesonotum; sides of the propodeum; metapleurae; mesopleurae; mesosternum. Long white hairs on: clypeus; frons laterally; temples (very long); sides of thorax. Dorsal area of propodeum glabrous. Wings subhyaline, the veins light brown. Morphology - clypeus rather depressed before apex, which is rounded; OOL = POL in one specimen (Gebel Asfar); in the other (Fayyum) OOL > POL; vertex impunctate; mesonotum impunctate; dorsal surface of propodeum with longitudinal mesal ridge, from which run diagonal striae.

Distribution: Fayyum, Gebel el Asfar

Flight: males (2-3)

Collections: AUCE

\section{CHLORIONTINAE}

Chlorion Latreille, 1802-1803

Species of the genus Chlorion may be recognized by the combination of a gastral petiole comprising only $\mathrm{S} 1$, the second recurrent vein being received by the third submarginal cell or interstitial between the second and third, tarsi with plantulae, tarsal claws with a single mesal (occasionally basal) tooth and the dorsal area of the propodeum with a U-shaped enclosed area. The genus is widely distributed but not found in Europe or Australia. The species prey on crickets, using the crickets own nests.

Key to species recorded from Egypt and Sinai:

1 Forewings yellow with a distinct infuscate margin 2

- $\quad$ Forewings infuscate with metallic reflections, indistinct margin ......... semenowi occidentale 
2 Hindwings without infuscate margin, dorsal surface of propodeum with straight and regular striae; $\delta$ with antennal segment 3 longer than 4 ................................................. funereum Hindwings with more or less distinct infuscate margin; dorsal surface of propodeum with rather irregular transverse striae, sinuate mesally; $\hat{\sigma}$ with antennal segment 3 shorter than 4 hirtum

splendidus species group

Chlorion funereum Gribodo, 1879

Chlorion funereum Gribodo, 1879: 343; $q$; holotype $q$ in MCSNG; loc. typ. Ethiopia = kingdom of Scioa (Schoa). [Kohl, 1895; de Beaumont, 1962; Guichard, 1988a.]

Egyptian synonyms:

Sphex (Chlorion) funereus: $\quad$ Honoré, 1944a; de Beaumont, 1962.

Chlorion funereum: Bohart \& Menke, 1976.

Colour:

Diagnosis (No specimens from Egypt or Sinai seen. Diagnosis made from specimens from Arabia and the Yemen.)

Colour: Head, thorax and abdomen black, the abdomen with slight violet or blue reflections, the head often with ferruginous markings on the temples and on the clypeus, frons and inner orbits. Propodeum and abdomen sometimes with ferruginous areas. Antennae more or less ferruginous. Legs black or ferruginous. Wings yellow, forewings with very distinct infuscate apical area, hindwings never with darkened area.

Morphology: Black pilosity less developed than on C. hirtum. Dorsal area of propodeum with regular striae, separated by shining spaces without any mesal rugosity; the striae may be regularly transverse but frequently the anterior ones are curved or angular; mesonotum without fine pubescence, anteriorly with coarse obliquely erect hairs; mesopleurae shining with distinct spaced punctures. Clypeus with a median longitudinal impunctate band forming a mesal not very sharp ridge. Male: Ant3 longer than Ant4; placoid-like areas on Ant3 or 4 to 10 . S1 and S2 with numerous obliquely erect hairs. Length: 18-24 mm. Female: Antennal segments shorter than in C. hirtum, the length of Ant3 being about three quarters of the interocular distance at the vertex. Dorsal length of the petiole clearly shorter than the length of the 3rd segment of tarsi 3 , scarcely longer than the 4 th. Clypeus with the four lateral teeth at the margin pointed, the median one little developed. Length: 27-32 mm

Range: Somalia to Chad, Algeria, Egypt, Sudan, Aden, N.Yemen, Saudi Arabia, Iraq.

Distribution: (Qena - according to Kohl, 1885b, per Honoré)

\section{Chlorion hirtum (Kohl, 1885)}

Sphex (Chlorion) hirtus Kohl, 1885: 176; đึ; holotype $\widehat{\jmath}$ in coll. NHMW; loc. typ. Egypt - Sinai, Tor or Cairo.

Egyptian synonyms: Sphex (Chlorion) hirtus

Honoré, 1942 \& 1944a; de Beaumont \& BytinskiSalz, 1955; de Beaumont, 1962.

Chlorion hirtum

Bohart \& Menke, 1976; Guichard, 1988a.

Diagnosis (28 males and 16 females from Egypt and Sinai examined.)

Colour: Wings yellow, forewings with very distinct infuscate apical area particularly in females, hindwings with less clear darker apical area which is occasionally very indistinct. Head, thorax and abdomen black, head and pronotal collar sometimes with dark ferruginous areas, abdomen without metallic reflections in females and sometimes with slight ones in males. Mandibles dark ferruginous tending to black. Antennae entirely ferruginous or ferruginous basally, darker above, and the apical segments black. Legs black, tibiae and tarsi more or less dark ferruginous, particularly the anterior ones. Males from Sinai have anterior legs bright ferruginous from apex of femora. In general, females are darker than males, the ferruginous either lacking or of a much darker colour. Hair of head, thorax, petiole and coxae black.

Morphology: Black pilosity more developed than in the other species, particularly in males. Propodeum striate with intermingled rugosity. Male: Anterior margin of clypeus tridentate; Ant3 very clearly shorter than Ant4. Pronotum transversely striate. S1 with long hairs beneath; S2 and subsequent sternites with only a few isolated hairs. Length: 21-33 mm. Female: Clypeus usually rather indistinctly carinate, the whole surface covered with dense microsculpture with widely spaced larger piligerous punctures; antennal segments long, Ant3 almost as long as the 
interocular distance at the vertex. Thorax with dense microsculpture on whole mesonotum giving rise to fine black pubescence, frequently lacking in worn specimens; punctation of mesopleurae dense but rather shallow. Length: $30-38 \mathrm{~mm}$. One female from Sinai only $26 \mathrm{~mm}$.

Range: Ethiopia to Egypt, Israel, Arabia (Red Sea coast), Oman, Arabian Gulf.

Distribution: Abu Rawash, Maadi, N Galala (Wadi el Garariyat), Ogret el Sheikh, Suez road, Wadi Abu Handal, Wadi Ambaga, Wadi Digla, Wadi Hagul, Wadi Hoff, Wadi Rishrash, W Galala, Wadi Garawi. Sinai - Umm Bugma, Wadi Feiran, Wadi Um Elek Kaiser.

Flight: males ( 1-6, 10 -11), females (2-5, 9-10). (Per Honoré - June to October)

Collections: AM, CGR, AUCE, PPDD, CUE

\section{Chlorion semenowi F. Morawitz, 1890 ssp. occidentale (de Beaumont, 1962)}

Chlorion semenowi F. Morawitz, 1890: 570, + ; holotype $q$ in coll. ZIL; loc typ. Transcaspia Tedshen. [de Beaumont, 1962.]

Chlorion bicolor Walker, 1871: 20,, ; loc. typ. Arabia Petraea - Wadi Gharandel (Sinai); (nec Saussure, 1869) [de Beaumont, 1962; Guichard, 1988a]

Sphex (Chlorion) semenowi occidentalis de Beaumont, 1962: 39-40, §,, ; holotype $q$ in coll. de Beaumont in MZL; loc. typ. Israel - Tel Jerucham.

Egyptian synonyms:

Chlorion bicolor

Sphex (Chlorion) regalis Smith, 1873

\section{Kohl, 1885.}

Honoré, 1942 \& 1944a; de Beaumont \& BytinskiSalz, 1955. This name was based on an incorrect determination, realised by van der Vecht and corrected by de Beaumont, 1962.

Sphex (Chlorion) semenowi occidentale de Beaumont, 1962. Chlorion semenowi occidentale Bohart \& Menke, 1976; Guichard, 1988a.

Diagnosis (8 males and 8 females from Egypt examined.)

Colour: Head, thorax and abdomen black with a variable amount of red markings on the clypeus, mandibles, frons, inner orbits, temples, vertex, pronotum and tegulae (absence of red on the mesonotum and scutellum and the less developed red on the pronotum characterises the subspecies); abdomen with metallic blue or violet reflections. Antennae usually red on Ant1-3 which may continue in a darker red to the apex, usually dark above. Legs black with red from the middle or the apex of the femora, but occasionally the femora are entirely red, the red on the posterior legs is usually darker than on the anterior and middle ones. Wings infuscated with metallic reflections.

Morphology: Pronotum anteriorly striate; mesoscutum and scutellum almost impunctate with only a faint microsculpture, shining; propodeum finely and evenly transversely striate; mesopleurae puinctate. Male: Ant3 slightly shorter than Ant4; Ant3 much wider apically than basally. Scutellum a little rounded with a median impression. S1 and S2 with one or two long hairs. Length: 15-19 mm. Female: As male, except Ant3 much longer than Ant4. Tarsal comb of stout black spines, metatarsi 1 with 5 spines and 4 fine ones on the posterior side. Length: 18-21 mm; de Beaumont (1962) gives 19-23mm.

Range: Egypt, Israel, Saudi Arabia, United Arab Emirates, Oman.

Distribution: Abu Rawash, Km94 Suez Road, 6th Tower Suez Road, Wadi Digla, Wadi Hagul, Wadi Hoff, Wadi Umm Assad. Sinai - El Arish (Wadi el Hadira).

Flight: males ( 6, 9-10), females (3, 6, 8-11). (Per Honoré - July to October)

Collections: AM, CGR, AUCE, PPDD, CUE

\section{SCELIPHRINAE}

\section{Sceliphrini}

\section{Chalybion Dahlbom, 1843}

The two Egyptian species of the genus Chalybion are metallic blue with a gastral petiole composed of only $\mathrm{S} 1$, both recurrent veins received in submarginal cell 2 and without a dorsal enclosure on the propodeum. The genus is widespread and its members nest in pre-existing cavities - in walls, holes in wood or in abandoned mud nests of Sceliphron. The nests are mass provisioned with spiders. 
Key to species recorded from Egypt and Sinai:

1 Sides of propodeum completely punctate with vertical ridges anteriorly flebile

- $\quad$ Sides of propodeum largely impunctate heinii

\section{bengalense species group}

\section{Chalybion flebile (Lepeletier, 1845)}

Pelopoeus flebilis Lepeletier, 1845: 321; Ô, + ; type lost; loc. typ. Turkey - Izmir.[Hensen, 1988; Guichard, 1988a.]

Pelopoeus targionii Carruccio, 1872: 273; type lost; loc. typ. Italy - Sardinia, Ozieri. [Hensen, 1988]

Egyptian synonyms:

Pelopeus violaceus Latreille Innes, 1911. Presumably "Latreille" is a lapsus for Fabricius.

Sceliphron violaceum Fabricius, 1775, nec Scopoli, 1763. Storey, 1916. This is an error common in collections, a misidentification because it is a synonym of $C$. bengalense (Dahlbom, 1845), an Oriental species.

Sceliphron (Chalybion) targionii Honoré, 1942, Alfieri, 1946. Chalybion flebile Hensen, 1988.

Diagnosis: ( 8 males and 5 females from Egypt seen.)

Colour: Head, thorax and abdomen entirely metallic blue-green. Antennae black, apart from metallic blue-green scapes; mandibles brown. Tegulae brown with metallic reflections. Legs with metallic blue coxae, from trochanters brown; femora 1 with metallic reflections, sometimes femora 2 also. Forewings darkened apically.

Morphology: Clypeus swollen, with a pronounced longitudinal mesal carina; there is a short carina to each side of this to the apical margin of the clypeus which in some positions can as a result seem to be tridentate; Ant $3=$ Ant 4. Mesonotum and scutellum punctate; dorsal area of propodeum transversely striate; sides of propodeum striate with scattered punctures up to the junction with the mesopleurae; mesopleurae punctate. Long silver hairs scattered on head and thorax; appressed silver hair on clypeus and frons, on pronotal tubercles, and at apex of propodeum above and to the side of the insertion of the petiole.

Length: males 11-14 mm, females 11-16 mm.

Range: Mediterranean region, Italy, Libya, Egypt, Crete, Israel, Syria, Oman, United Arab Emirates, Iraq, Iran.

Distribution: Abu Rawash, Abu Sir, Benha, Borgash, Cairo (Zamalek), Fayyum, Gebel el Asfar, Giza, Giza (Pyramids), Khatatba, Maadi, Mansoura, Marg, Saqqara, Sentris, Shebin el Kom, Warrak. Sinai - Wadi el Lega (S.Sinai).

Flight: males (2, 4-7, 9), females (4-10)

Collections: AM, ASUA, CGR, PPDD, CUE

\section{tibiale species group}

\section{Chalybion heinii (Kohl, 1906)}

Sceliphron (Chalybion) Heinii Kohl, 1906: 189, 194, 197; §, , +; type in coll. NHMW; loc. typ. "Gischin, S. Arabia" (S. Yemen - Qishn). [Hensen, 1988.]

\section{Egyptian synonyms:} $\mathrm{CU}$ has a specimen which is the first record from Egypt.

Diagnosis: (1 male and 3 females from Egypt seen.)

Colour: Head, thorax and abdomen entirely metallic blue-green. Antennae black, the scapes with metallic reflections. Legs brown, the femora with metallic reflections, the anterior ones blue-green, the middle and hind ones purple. Wings darkened apically.

Morphology: Very similar to C. flebile except: Mesal carina of clypeus less marked, not reaching apical margin. Propodeum laterally largely smooth and shining; mesopleurae less densely punctate. Silver hairs on thorax more numerous.

Length: males (13 mm), females (15-17 mm)

Range: Ethiopia, Sudan, Egypt, Saudi Arabia.

Distribution: Burg el Arab, Gebel Elba 
Flight: male (12), females $(10,12)$

Collections: PPDD, CUE (first record from Egypt)

\section{Sceliphron Klug, 1801}

The black and yellow species of the genus Sceliphron are readily recognized by having the combination of a very long gastral petiole composed of only S1, both recurrent veins received in submarginal cell 2 and a U-shaped dorsal enclosure on the propodeum. These wasps, known as "mud daubers", make their nests of mud from some damp place which is placed in a sheltered locality, often on a house or other building. They mass provision their nests with spiders. The genus is widespread.

Key to species recorded from Egypt and Sinai

1 Hind coxae swollen on outer side, as seen from above or below distinctly angular; mandibles simple; tegulae and metanotum black spirifex

- $\quad$ Hind coxae narrow or slightly swollen, rounded on outer side; mandibles with more or less distinct tooth; tegulae and metanotum marked with yellow madraspatanum tubifex

\section{madraspatanum species group}

The madraspatanum species group is characterised by the shape of the hind coxae as indicated in the key to Egyptian species.

\section{Sceliphron madraspatanum (Fabricius, 1781) ssp. tubifex (Latreille, 1809)}

Sphex madraspatana Fabricius, 1781: 445; type in BMNH; loc. typ. Malabar. [van der Vecht \& van Breugel, 1968.]

Pelopoeus tubifex Latreille, 1809: 61; no loc. typ. given. [van der Vecht \& van Breugel, 1968.]

Egyptian synonyms:

In coll CGR; taken at Tell el Kebir, the first record from Egypt. It is of interest that van der Vecht \& van Breugel, 1968, in their revision of the nominate subgenus, Sceliphron specifically mention that this species has not been recorded from Egypt.

Diagnosis: ( from the only male seen from Egypt)

Colour: Black with the following yellow - pronotal collar with two transverse spots, mesonotum with spot on each posterolateral corner, tegulae, scutellum with transverse spot, metanotum with transverse spot, propodeum with two spots apically just above the insertion of the petiole, S1 (petiole), fore and middle legs - apical half of femora, tibiae and metatarsi, hindlegs trochanters, base of femora, basal half of tibiae, metatarsi. Apical half of mandibles and the remainder of tarsi are brown. Frons and clypeus covered with silver pubescence. Head and thorax with sparse pale hairs.

Morphology: Apex of clypeus mesally emarginate. Mesonotum rugose; scutellum rugose tending towards longitudinally striate; metanotum longitudinally striate; dorsal area of propodeum rugose; lateral area of propodeum horizontally striate; mesopleurae with coarse punctures on a distinct microsculpture. Coxae 3 viewed from above rounded and not angular. Submarginal cell 2 subequal to 3 on $\mathrm{RS}$.

Length: male (16 mm)

Range: Morocco to Tunisia, s. Europe, Egypt, Israel, Turkey, Crete, Oman, Iran, sw. USSR.

Distribution: Dakhla Oasis, Tell el Kebir.

Flight: male $(1,7)$

Collections: ASUA, CGR

Note: First record from Egypt

\section{spirifex species group}

\section{Sceliphron spirifex (Linnaeus, 1758)}

Sphex spirifex Linnaeus, 1758: 570; loc. typ. “"in Europa australi” [Arnold, 1928; van der Vecht \& van Breugel, 1968; Guichard, 1988a.] Sphex aegyptia Linnaeus, 1758; 569, “in Aegyptia" [van der Vecht \& van Breugel, 1968]. [Note: according to the World Catalog, this name was synonymized by Dalla Torre 1897: 391 
by treating the name as a variety of spirifex, but this is wrong and the current situation where aegyptia has page precedence over spirifex is contrary to Article 23.3.1 of the Code]

Egyptian synonyms:

Pelopeus spirifer (sic)

Innes, 1911.

Sceliphron spirifex

Storey, 1916; Alfieri, 1946; de Beaumont, 1950c;

Pelopaeus (Sceliphron) spirifex

Sayed et al, 1964.

Diagnosis: (71 males and 88 females from Egypt and Sinai seen.)

Colour: Black except: S1 (petiole) yellow. Anterior and middle legs with yellow on the femora from the middle on the upper side and from the apex beneath, the tibiae yellow and the tarsi yellow or light brown; sometimes the metatarsi are black basally and yellow thereafter. Posterior legs with the trochanters, the basal half of the femora and the basal half of the tibiae yellow; the tarsi may be yellow or light brown or, occasionally, black or a combination of these. Mandibles brown. Antennae with the scape brown or yellow beneath. Tegulae often brown. Head and thorax with dark hair.

Morphology: Mandibles simple with no tooth on the inner side. Mesonotum rugose-punctate anteriorly (sometimes tending to be transversely striate) and posteriorly often longitudinally or obliquely striate with punctures between the striae; scutellum rugose or longitudinally striate; dorsal area of propodeum anteriorly obliquely and sometimes posteriorly transversely striate; sides of propodeum strongly and coarsely obliquely striate above, smooth below; mesopleurae finely punctate over a distinct microsculpture and shining. Hind coxae swollen on outer side, as seen from above or below, distinctly angular. Submarginal cell 3 normally longer on the radius than the second, occasionally subequal. Male: Ant3 longer than Ant4; apex of clypeus emarginate. Length: 12-20 mm. Female: Ant3 longer than Ant4; apex of clypeus with two large flat lobes (one specimen from Kom Awshim lacks these lobes and the apical margin of the clypeus is entire and slightly convex). Length: $16-25 \mathrm{~mm}$.

Range: All tropical Africa, circummediterranean, Asia minor; Canary Is., Cape Verde Is., Morocco, Algeria, Egypt, Israel, Lebanon, Turkey, Crete, Oman.

Distribution: Abu Rawash, Aswan, Baharia Oasis, Belbeis, Beni Youssef, Borgash, Burg el Arab, Cairo (City Centre, Ein Shams), Dakhla Oasis (Al Qasr, Rushda, Tineida), Damietta, Ezbet el Nakhl, Fayyum (Karanis, Lahun), Gebel el Asfar, Giza, Giza (Pyramids), Helwan, Kafr Dawar, Kerdasa, Khattara, Kharga Oasis, Kom Awshim, Marg, Ogret el Sheikh, Qaha, Sentris, Suez, Suez Road, Tell el Kebir, 10th Ramadan City, Tisfa, Wadi el Natrun (Beaar Ashra, El Maahad el Dini, El Mashtal, Kafr Dawood, Rest House), Zagazig. Sinai - El Arish

Flight: males (1-12), females (1,3-12)

Collections: AM, ASUA, CGR, AUCE, PPDD, CUE

\section{SPHECINAE}

\section{Prionychini}

\section{Palmodes Kohl, 1890}

Generically, Palmodes is very close to Prionyx, both genera being placed in the subtribe Prionyxina, having a narrow second submarginal cell, no spiracular groove on the propodeum and the pecten of the hind tibia coarse. The females of Palmodes may be distinguished from those of Prionyx by the margin of the clypeus: in Palmodes this has a truncate or slightly concave median lobe bounded at each side by an emargination. The males have two teeth on their tarsal claws, and no placoids on the antennae; there is no dense white or silver appressed pubescence on the head or thorax and the tergites are not cream-coloured on the posterior margins. Members of this Holarctic genus are reported to nest in cracks in stone walls as well as in the ground. They provision their nests with Orthoptera. Only one species has been cited from Egypt and the Sinai. Spinola (1839) cited it, according to Honoré (1944a), as having been found in Egypt but Honoré had doubts as to the correctness of the determination.

Palmodes occitanicus (Lep. \& Serv., 1825) ssp. cyrenaicus (Gribodo, 1924)

Sphex Occitanica Lepeletier \& Serville, 1825: 462, $\hat{\partial}$; syntype $\delta$ from Montpellier, France, held in ?MNHN. [Kohl, $1885 \&$ 1890.]

Sphex cyrenaica, n. sp., Gribodo, 1924: 263-266, ô,, ; loc. typ. Libya - Benghazi 
Egyptian synonyms:
Sphex (Palmodes) occitanicus
Honoré, 1942 \& 1944a.

Diagnosis: No specimen from Egypt seen. The above diagnoses made from Italian (Sardinian) specimens. This species exists with a very wide range in a number of subspecies. It is not known which occurs in Egypt or Sinai, if any.

Colour: black, except on the following. Red areas are: T1, T2, T3 basally, S1, S2, sometimes S3. Male with a little silver appressed hair on clypeus and frons, which is not dense. This is lacking in the female. Head and thorax with longer hairs black. Wings slightly infuscated, veins dark.

Morphology: Males - antennae with linear carinae on Ant6-9; clypeus with margin mesally straight, rather flat, punctate over a microsculpture; pronotum longitudinally finely striate; mesonotum punctate; scutellum longitudinally striate; propodeum with dorsal area transversely striate, laterally rugose; mesopleurae rugose; petiole dorsally subequal in length to metatarsus 3 . Length $19 \mathrm{~mm}$. Females - clypeus with mesal lobe somewhat concave, separated by a notch from the lateral lobe, somewhat depressed laterally, punctate over a microsculpture; pronotum with sparse fine punctures over microsculpture; mesonotum with fine punctures more dense than the pronotum, also over microsculpture; propodeum with dorsal area finely transversely striate, laterally striate with punctures between the striae; mesopleurae rugose; petiole a little shorter than metatarsus 3. Length $20 \mathrm{~mm}$.

Range: N.Mediterranean region, Spain, Morocco, Algeria, Tunisia, Libya Cyrenaica, Turkey, Afghanistan, China

\section{Prionyx Van der Linden, 1827}

Like Palmodes, Prionyx has the narrow second submarginal cell, the absence of a spiracular groove on the propodeum and the pecten of the hind tibial spur usually coarse, which characters separate these two genera from Sphex. Distinguishing this genus from Palmodes is less easy. The female clypeal margin is either mesally notched or is entire, lacking the notches on either side of the mesal lobe. The males have two, three or four teeth on their tarsal claws. Some species have placoids on some antennal segments. Those species with tarsal claws with two teeth and no placoids (as Palmodes) have dense white appressed pubescence on the head and thorax and cream-yellow apical bands on some tergites. Members of the genus nest in the ground and furbish their nests with orthopterous prey. Species of this genus were formally regarded as members of various subgenera of the genus Sphex s.l. (sensu Kohl). Following Bohart \& Menke (1976), it is the present practice to use species groups instead of the subgenera.

Key to the species groups occurring in Egypt:

1 Tarsal claws with 3,4 or 5 teeth at the base of the inner margin; (male antennae without placoids)

Prionyx = Parasphex $)$

Tarsal claws with 2 teeth ....................................................................................... 2

2 Abdomen light ferruginous, the apices of the tergites with a clearly visible paler margin; male antennae without placoids ................................................. niveatus group (= Calosphex)

Abdomen black, tergites without paler apical margin; male antennae with placoids

(Harpactopus $=$ Priononyx) 3

3 Female clypeus with U-shaped mesal notch; male Ant3 clearly shorter than Ant5; wings usually yellow crudelis group

- $\quad$ Female clypeus entire or weakly obtuse with V-shaped emargination; male Ant3 clearly shorter than Ant5; wings hyaline with apex infuscated or very strongly infuscated all over 4

4 Tibiae without small spines between the large ones; SMC2 narrow, parallel sided; females with mesonotum largely and scutellum entirely shining; males without expansions on posterior angles of S6 stschurowskii group

- $\quad$ Tibiae with spinicules more or less developed between spines; SMC2 wider below; females covered with dense silver pilosity or strongly sculptured; males with reflexed rounded lobes on postero-lateral angles of S6. macula group 


\section{crudelis species group}

This species group ( = Harpactopus in part) shares the following characters with the macula and stschurowskii species groups: tarsal claws with two teeth; abdomen black and globular. The Egyptian species have the following characters in common: forewings yellow, infuscate apically; metanotum with mesal tubercle, especially in female; female clypeal margin with distinct mesal U-shaped notch; male clypeal margin broadly emarginate; male flagellum with placoids; male Ant3 longer or scarcely shorter than Ant5.

Key to the Egyptian species:

1 SMC2 parallel sided, not narrowed on Rs subfuscatus (Dahlbom)

- SMC2 distincly narrowed on Rs 2

2 Male antennae with narrow placoids on Ant5 \& 6; smaller species; legs less spinose; metanotal tubercle smaller judaeus (de Beaumont)

- Male antennae with broad flat placoids on Ant5-7; larger species; legs more spinose; metanotal tubercle very marked crudelis (F.Smith)

\section{Prionyx crudelis (F.Smith, 1856)}

Sphex aegyptia Lepeletier, 1845: 356, +; loc.typ. 'Egypt', in MRSN; (nec Linnaeus, 1758 = Sceliphron spirifex). [synonymised with crudelis by Kohl, 1885 \& 1890.]

[Sphex aegyptica Taschenberg 1869: 412 (redescription of aegyptia, presumably an error) ]

Harpactopus crudelis Smith, 1856: 264, o; type from Madras, India (BMNH). [Kohl, 1885 \& 1890.]

Egyptian synonyms:

Sphex aegyptius

Kohl, 1885; Storey, 1916; Honoré, 1942; Bohart \& Menke, 1976. Kohl, 1885, only gives Khartum for Egypt!

Sphex (Harpactopus) soror Dahlbom, 1845 Sphex (Priononyx) crudelis

Honoré, 1942 \& 1944a.

de Beaumont, 1950c; de Beaumont \& BytinskiSalz, 1955; de Beaumont, 1966.

Diagnosis: (26 males and 8 females examined.)

Colour: black; mandibles sometimes in part dark ferruginous; silver appressed pubescence on clypeus and frons up to median ocellus and on the dorsal surface of the pronotum; frons also has some longer erect black hairs; black (occasionally somewhat brownish black) pubescence elsewhere, particularly on the temples, prosternum and propodeum; wings yellow, with infuscate apex in the forewing, the veins a light brown.

Morphology: Males - clypeus somewhat swollen, broadly emarginate mesally; Ant3 a little longer than Ant4, narrow basally. Ant3 and Ant 4 with a longitudinal carina. Wide, flat placoids from the apex of Ant5; mesonotum densely punctate almost rugose, the punctures tending to form longitudinal striae; metanotum with a very marked mesal conical tubercle, on either side of which are transverse striae; propodeum dorsally rugose, laterally rugose or very densely punctate, sometimes vertically striate with punctures between the striae; femora shining with scattered punctures and some hairs; tibiae and tarsi with extremely dense hairs interspersed with longer spines. Length 19-24 mm. Females - apical margin of clypeus with mesal U-shaped notch, immediately above which is a large oval depression; Ant 3 curved and very much longer than Ant4, almost equal in length to Ant5; pronotum laterally striate; mesonotum punctate, anterolaterally the punctures merging into transverse or oblique striae; scutellum with mesal depression, punctate mesally and longitudinally striate laterally; metanotum with marked mesal conical tubercle; propodeum, metapleurae and mesopleurae rugose-striate; tubercle anterior to mid-coxae; legs as in male; SMC2 distinctly narrowed anteriorly (i.e. on Rs). Length: 27-33 $\mathrm{mm}$.

Range: Mauritius, Zambia to Libya, Egypt, Israel, Syria, Turkey, sw USSR; Saudi Arabia to India and Sri Lanka

Distribution: Dakhla Oasis (Mut), Ein Shams, Ezbet el Nakhl, Gebel el Asfar, Giza, Giza (Pyramids), Kerdasa, Kom Awshim ( = "Fayyum" in Coll. Mochi; = "Km65 Fayyum road" in Coll. CUE), Maadi, Marg, 10th Ramadan City, Wadi Digla, Wadi Hoff. Sinai - Wadi el Lega 
Flight: males (3, 5-10), females (4-7, 9-11)

Collections: AM, CGR, CUE

\section{Prionyx judaeus (de Beaumont, 1968)}

Sphex (Priononyx) judaeus de Beaumont, 1968b: 150-152, $\widehat{\jmath}, \uparrow$; holotype $q$ in coll. MZL; loc. typ. Israel - Jericho.

Egyptian synonyms:

In Coll CGR; taken in Wadi Digla; the first record from Egypt.

Diagnosis: (made from 2 males only)

Colour: Male - black; wings yellow, particularly at base, apically somewhat infuscated, the veins yellow brown; pubescence black, long and coarse on the clypeus, frons, vertex, temples and pronotum, short and suberect on the mesonotum anteriorly, propodeum and coxae.

Morphology: Male - clypeus widely emarginate, in an arc; Ant3 wider apically and longer than Ant5; narrow very distinct placoids on Ant4 and Ant6; pronotum without mesal impression; mesonotum striate; scutellum longitudinally striate; metanotal tubercle much less than in $P$. crudelis; propodeum transversely striate, but rugose between; mesopleurae striate; spinosity of tibiae 3 mid-way between that of $P$. crudelis and $P$. subfuscatus, the longer stronger spines being flattened and not immediately obvious; SMC2 distinctly narrowed anteriorly (i.e. on Rs). Length: $12-18 \mathrm{~mm}$.

Range: Israel, Egypt

Distribution: Wadi Digla

Flight: males $(5,6)$

Collections: CGR (first record from Egypt)

\section{Prionyx subfuscatus (Dahlbom, 1845) ssp. subfuscatus (s.s.)}

Sphex subfuscatus, Dahlbom, 1845: 436, ô; type from Ukraine (lost) [Kohl, 1885 \& 1890.]

Egyptian synonyms:

Sphex soror Dahlbom, $1845 \quad$ Kohl, 1885 \& 1890.

Sphex subfuscatus

Kohl, 1885.

Sphex (Harpactopus) subfuscatus Kohl, 1890; Honoré, 1944a.

Diagnosis: (one Egyptian female seen; the male diagnosis was made from a Sardinian specimen.)

Colour: black, except the mandibles are sometimes a very dark ferruginous and the tarsal claws a lighter ferruginous; wings yellow with infuscated apices; the veins are brown except for the yellow brown costa; slight silver appressed pubescence on the clypeus and frons; other erect pubescence is black, not dense on the clypeus, vertex, temples, pronotum, anterior of the mesonotum propodeum (longer posteriorly and laterally).

Morphology: Males - clypeus with a mesal notch Ant5 - Ant8 with flat placoids much wider than those of $P$. judaeus; Ant3 slightly shorter than Ant5 and only a little wider apically than basally; mesonotum obliquely striate; scutellum longitudinally striate; metanotum with mesal conical protuberance which is not sharp; propodeum striate, dorsally transversly; mesopleurae rugose; tarsi 3 without second, longer and stouter spines; SMC2 narrow but parallel sided. Length ca. $12 \mathrm{~mm}$. Females - clypeus with mesal motch and above it a depression; Ant 3 slightly flattened and subequal in length to Ant5; mesonotum shining with microsculpture only; scutellum shining, rounded with a slight mesal depression; metanotum with a conical protuberance; propodeum with dorsal area rugose with a tendency to become transverse striae, laterally striate; mesopleurae striate; tarsi 3 without second, longer and stouter spines; SMC2 narrow but parallel sided. Length $21 \mathrm{~mm}$. A Sardinian female differs from the above as follows: the appressed pubescence of the clypeus and frons is golden rather than silver; the wing veins are yellow brown; Ant3 is not flattened; the mesonotum is somewhat rugose; the metanotal protuberance is slighter; the mesopleurae are rugose; length $18 \mathrm{~mm}$.

In view of the few examples seen, it is not known whether the Sardinian differences may be applicable to other specimens from Egypt.

Range: Spain, France, Italy, Algeria, Israel, Turkey, Oman, India, China

Distribution: [Port Said] (cited from Egypt by Kohl after specimens in Vienna Museum - per Honoré), Sinai, Wadi Feiran, St Katherine

Flight: female (6)

Collections: CUE 


\section{kirbii species group}

Members of the kirbyi species group (= Prionyx s.s. and = Parasphex) have the following characters in common: tarsal claws with three teeth (sometimes there is a weak fourth one); metapleura with a channel to receive the hind femora; male antennae without placoids; female clypeal margin either entire or with a v-shaped notch; female last sternite keel-like. Egyptian species have red abdomens (at least in part) and the tergites with a pale apical margin.

Key to the Egyptian species (excluding nudatus):

Males:

1 Tarsal claws with 4 teeth; abdomen red 2

Tarsal claws with 3 teeth; abdomen red more or less marked with black 3

2 Scutellum flat without median impression; pubescence whitish-grey not appressed; length $14-16 \mathrm{~mm}$ lividocinctus (Costa)

- Scutellum with two shining tubercles; dense silver pubescence mingled with erect white hairs; length $12-15 \mathrm{~mm}$ trichargyrus (Spinola)

3 Abdomen almost entirely red with black spots on T4-6; length $14-20 \mathrm{~mm}$..... viduatus (Christ)

- Abdomen black, the first two segments red, the subsequent segments with a more or less distinct ivory white apical band; length $13-16 \mathrm{~mm}$ kirbyi (Van der Linden)

Females:

1 Scutellum flat, without a median impression; [margins of the tergites decolored; wings slightly yellow; tarsal claws with 4 teeth; length $15-20 \mathrm{~mm}]$ lividocinctus (Costa)

- Scutellum with two tubercles 2

2 Tarsal claws with 4 teeth; [apices of tergites decoloured; silver pubescence covering the head, thorax and the base of the abdomen] trichargyrus (Spinola)

- Tarsal claws with 3 teeth 3

3 Abdomen red, the posterior tergites with black marks; propodeum with white pubescence except for a U-shaped area viduatus (Christ)

- Abdomen red, the tergites after T2 with narrow ivory apical bands; propodeum entirely covered with white pubescence kirbyi (Van der Linden)

\section{Prionyx kirbii (Vander Linden, 1829) ssp. kirbii (s.s.)}

Sphex albisecta Lepeletier \& Serville, 1828: 462, ô, ․ . type from Italy (MNHN) [Kohl, 1885 \& 1890.]

Ammophila Kirbyi v.d.Linden, 1829: 90; types from France \& Spain (lost) [Kohl, 1890.]

Egyptian synonyms: Sphex (Parasphex) albisectus Lepeletier \& Serville, 1828 Honoré, 1942 \& 1944a: 63.

Diagnosis: (4 males and 3 females examined.)

Males: Colour - head and thorax black; mandibles and tegulae very dark ferruginous or black; abdomen - petiole black; T1-3 red, sometimes T3 is black in part; T4-7 black; T2-6 with narrow yellow band before the decoloured margin; legs - coxae, trochanters, femora black, femora 3 is sometimes ferruginous basally; tibiae and tarsi dark ferruginous, sometimes completely black; silver appressed pubescence on clypeus and frons densely, less dense on sides of mesonotum posteriorly, propodeum laterally and the posterior of the mesopleurae; this pubescence is less dense than on viduatus; longer white hairs mixed with the appressed hair on head and thorax; wings hyaline; veins yellow brown basally, darker apically. Morphology - clypeus somewhat gibbous, its apical margin entire, with scattered punctures; antennae without placoids; pronotum rounded and punctate; mesonotum punctate; scutellum rounded with mesal impression, sometimes very slight, punctate; propodeum dorsally punctate, the punctures running together to form transverse striae; laterally striate, often obscured by the pubescence; metanotal channel shining; petiole equal in length to hindtarsomeres $1+2$; wings with 1 st recurrent vein received in SMC2 and the second in SMC3; SMC2 a little narrower anteriorly. Length: 12-15 mm. 
Females: Colour - head and thorax black, except mandibles and tegulae very dark ferruginous; abdomen - petiole black; T1-3 red, sometimes dark dorsally; T4-6 black; margins decoloured without yellow subapical bands or T2 and T3 with very narrow bands; S6 red; legs dark ferruginous to black, tarsi ferruginous basally; silver appressed pubescence much less than on male; long white hairs on clypeus and temples, more sparsely, also on vertex, pronotum, mesonotum, posterior sides of propodeum and coxae; wings hyaline; veins yellow brown at base, darker apically. Morphology - clypeal margin with mesal notch, often scarcely visible because of the pubescence; vertex, pronotum, mesonotum and scutellum shining and sparsely punctate; dorsal surface of propodeum striate with punctures between; metanotal channel shining and impunctate; mesopleurae punctate; wings as in male. Length: 13-17 mm.

Range: S.Europe, Hungary, Algeria, Libya, Egypt, Israel, Turkey, s.Palaearctic region in Asia

Distribution: Abu Rawash, Gebel el Asfar, Kom Awshim ( = "Fayyum" in Coll. Mochi, and "Fayyum 53" in Honoré 1944), Mersa Matruh, Saqqara, Suez Road, Tisfa, $35 \mathrm{~km}$ e of Wadi el Natrun, Sinai - El Arish.

Flight: males $(3-5,8,10)$, females $(4-7,10)$

Collections: AM, CGR, CUE

\section{Prionyx lividocinctus (A.Costa, 1858) ssp. lividocinctus (s.s.)}

Enodia lividocincta A.Costa, 1858: 30, ô, o; types from Italy (MZUN). [Kohl, 1885 \& 1890.]

Egyptian synonyms: Sphex (Parasphex) lividocinctus Honoré, 1944a.

Diagnosis: (no specimens seen from Egypt; diagnosis made from Sardinian specimens.)

Males: Colour - black, except tegulae very dark ferruginous, T1 to basal half of T3 red, S2 \& S3 red, tarsi dark ferruginous; silver appressed pubescence on clypeus, frons, sides and posterior of propodeum, mesopleurae \& coxae; long white hairs on clypeus, frons, vertex, temples, prothorax and sides and posterior of propodeum; wings yellowish basally; veins dark. Morphology - clypeal margin with notch and a depression above it; scattered punctures; antennae without placoids; Ant3 longer than Ant5; POL > OOL (slightly); vertex with scattered punctures; pronotum rounded; mesonotum and scutellum with scattered punctures; scutellum flat without median impression; propodeum dorsally transversely striate, laterally striate; petiole slightly longer than hind tarsomeres $1 \& 2$ together; SMC2 parallel sided. Length ca. $15 \mathrm{~mm}$.

Female: Colour - black, except red are the mandibles (black apically), tegulae (dark ferruginous), T1-T3, S1 after black petiole, S2-S4; tibiae dark ferruginous apically; tarsi dark ferruginous; silver appressed pubescence on clypeus, frons up to anterior ocellus, anterior surface of scape, pronotum posteriorly and laterally, mesonotum lateral and posterior bands, lateral and posterior surfaces of propodeum, mesopleurae and mesosternum, coxae, femora 1, trochanters $2 \& 3$; long white hairs on clypeus, frons (shorter), temples, pronotum (sparse), mesonotum (scattered); coxae, trochanters and basal half of femora 1 with erect stiff white hairs; wings yellowish; veins brown. Morphology - clypeus with mesal notch; Ant3 longer than Ant5; POL > OOL; pronotum rounded; mesonotum with scattered punctures; scutellum flat without mesal impression; propodeum with dorsal area transversely striate; petiole longer than hind tarsomere 1; tarsi 1 with long comb of fine brown hairs with pale stout spines; on anterior surface, long semi-recumbent hairs, on inner side stout white spines; SMC2 almost parallel sided. Length 17 mm.

Range: Spain, France, Italy, Greece, Algeria, Libya, Egypt, Turkey, Iran, sw USSR

Distribution: Hawamdieh (this species seems to be quite rare - per Honoré)

Flight: (6 per Honoré)

\section{Prionyx nudatus (Kohl, 1885)}

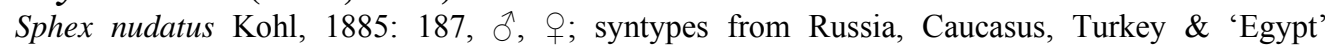
(NHMW)

Egyptian synonyms: Sphex (Parasphex) nudatus Honoré, 1944a.

Diagnosis: (No specimens available to be examined.)

Range: Nw Africa, sw Europe, Egypt, e Mediterranean area, Turkey, Iran, Afghanistan, sw USSR

Distribution: Not known from Egypt to Honoré. Cited from Egypt by Kohl after some specimens in Vienna Museum (per Honoré) 


\section{Prionyx trichargyrus (Spinola, 1839)}

Sphex trichargyra Spinola, 1839: 466-467, đ̇; lectotype đ̊ from 'Egypt' (MRSN). [Kohl, 1890; Guichard, 1988a.] [Kohl, $1890 \& 1895$, puts this as a synonym of albisectus ie of kirbii] Sphex (Parasphex) leucosoma n. sp., Kohl, 1890: 338; loc. typ. Egypt - Cairo.

Egyptian synonyms:

Sphex (Parasphex) leucosoma

Sphex (Parasphex) trichargyrius (sic)

Prionyx trichargyrus

Sphex (Parasphex) marginatus F. Smith var.
Kohl, 1890.

Honoré, 1944a: 65.

Bohart \& Menke, 1976; Guichard, 1988a.

Honoré, 1942. There must

be doubt about this record of Honoré, because, while leucosoma is a synonym of trichargyrus, marginatus is the Ethiopian region subspecies of Prionyx kirbii.

Diagnosis: (1 Egyptian male examined.)

Males: Colour - black, except: mandible red in middle between black base and apex; tegulae red; abdomen including petiole red; apex of T2-T6 with creamy yellow margin; legs with apex of tibiae and tarsi red; silver appressed pubescence on clypeus, frons, temples, thorax except scutellar tubercles (rubbed?), coxae, trochanters and upper surface of femora; long white hairs on clypeus, vertex, temples, pronotum, mesonotum, sides and posterior of propodeum, mesopleurae, femora 1 and coxae 3; silver pruinosity on T1, T2, T6 and T7; wings hyaline; veins light brown, apically darker brown. Morphology - clypeus apically truncate; Ant $3>$ Ant5; no placoids; POL > OOL; vertex sparsely punctate; mesonotum seems sparsely punctaate, but pubescence covers most of the surface; scutellum raised without mesal depression, shining and glabrous; propodeum seems to be transversely striate, but pubescence covers most of the surface; petiole $>$ hind tarsomere $1+2$; SMC2 narrowed anteriorly; SMC1 receives recurrent vein 1; recurrent vein 2 interstitial between SMC2 + 3. Length: $10 \mathrm{~mm}$.

Females: No specimens examined

Range: Senegal, Egypt

Distribution: Gebel el Asfar, Mazghouna, Saqqara, Suez road

Flight: males $(5,7)$, females $(5-7)$

Collections: AM, CGR

\section{Prionyx viduatus (Christ, 1791) ssp. viduatus (s.s.)}

Sphex viduata Christ, 1791: 305; loc. typ. Provence, France (lost) [Arnold, 1928; Guichard, 1988a.]

Egyptian synonyms: Sphex (Parasphex) viduatus Honoré, 1942 \& 1944a.

Sphex (Prionyx) viduatus de Beaumont, 1950c.

Diagnosis: (8 males and 23 females examined.)

Males: Colour - head and thorax black, except: clypeus sometimes with very narrow red line apically, labrum red, tegulae sometimes very dark ferruginous; abdomen red, except T1-T6 with decoloured margin, T4-T6 black on dorsal surface, T2-T6 with yellowish band before decoloured margin (occasionally these are lacking), T3 sometimes darkened on disk, T7 dark ferruginous; legs black, except tarsal claws dark ferruginous; silver appressed pubescence on clypeus, frons, scape externally, temples and occiput, most of thorax, except posterior part of tegulae, disk of mesonotum, raised part of scutellum, coxae, trochanters above, femora 1 posterior surface and below, femora $2 \& 3$ anterior surface and above, tibiae and tarsi; long white hairs on clypeus, frons, vertex (sparse), temples, occiput, pronotum, mesonotum (anterior), lateral and posterior surfaces of propodeum, mesopleurae, mesosternum, base of petiole, coxae 3 and femora 1 beneath; silver pruinescence on T1, T5 and T6 laterally; wings hyaline; veins dark brown. Morphology - clypeal margin straight or slightly emarginate, with a transverse impression slightly above the margin, scattered punctures over a microsculpture; Ant3 > Ant5; POL > OOL; vertex with sparse fine punctures; pronotum sometimes with the appearance of having a transverse carina beneath the pubescence; dorsal area of mesonotum glabrous, sparsely punctate and shining; scutellum rounded, mesally glabrous with median impression; propodeum with the dorsal area transversely striate, laterally striate; mesosternum coarsely punctate; remainder of thoracic surfaces obscured by pubescence; petiole in profile slightly curved, subequal in length to hind tarsomeres 1 + 2; SMC2 parallel sided. Length 11-16 mm. 
Females: Colour - head and thorax black, except tegulae dark ferruginous and often a narrow red apical band on the clypeus; abdomen with petiole black and the remainder red with black spots (sometimes lacking); sometimes T4 \& T5 are predominantly black; T2 - T4 with decoloured apical margin preceded by a narrow yellow band which is sometimes not distinct; the amount of black is variable; the yellow bands are most distinct on specimens with little or no black; tarsal claws dark ferruginous; stout spines on tibiae and tarsi ivory; tarsal comb black; silver appressed pubescence is dense on head and thorax, sparse on the vertex, lacking on the metapleurae, often lacking laterally on the mesonotum and scutellum, but always with a lyre shaped area on the dorsal surface of the propodeum lacking this pubescence; this pubescence is also to be seen on the coxae, trochanters and femora but it is often rubbed off; longer white hairs on clypeus, vertex (sparse), temples, pronotum, sides and posterior of propodeum, coxae and femora 1; wings hyaline; veins dark. Morphology - clypeus swollen, its apex entire or with mesal emargination vertex with scattered fine punctures; Ant3 > Ant5; POL subequal to OOL; pronotum shining; mesonotum usually shining, with scattered fine punctures, sometimes with denser coarser punctures; scutellum rounded usually with mesal impression, shining and impunctate, sometimes with no impression and scattered punctures; propodeum transversely finely striate dorsally anteriorly, less so posteriorly, laterally with coarse longitudinal striae; mesopleurae matt, punctate tending to rugosity; petiole subequal to hindtarsomere 1 (Roth says it is $<$ than hind tarsomere 1); tarsi with 3 claws although sometimes a rudimentary fourth one can be seen; SMC2 slightly wider anteriorly. Length: 17-22 mm.

Range: Africa, Spanish Sahara, Morocco, Libya, Egypt, Israel, Turkey, Greece, Crete, Saudi Arabia to India, Oman, Socotra, China, Taiwan, Ryukyus

Distribution: Abu Rawash, Fayyum (Hawara, Karanis), Gebel el Asfar, Ghoubret el Bous, Giza, Helwan, Kerdasa, Kom Awshim ( = Fayyum in Coll. Mochi), Mazghouna, Siwa Oasis, Wadi Digla, Wadi Hagul

Flight: males (3-10), females (4-7, 9-10)

Collections: AM, CGR, CUE

\section{macula species group}

This species group (= Harpactopus in part) shares the following characters with the crudelis and stschurowskii species groups: tarsal claws with two teeth; abdomen black and globular. It shares with the stschurowskii species group the following characters: male Ant3 clearly shorter than Ant5; male antennae with curved placoids, the placoid-bearing flagellomeres thicker and longer than the others; female clypeus without a distinctly limited mesal emargination, often more or less depressed before the emargination. It distinguishes itself from the stschurowskii species group by the following characters: tibiae with spinules more or less developed between the spines; SMC2 generally wider below; recurrent vein 2 received by SMC2 at its basal angle; black pilosity less abundant on the propodeum; male with lateral expansions on the posterior angles of S6; female mesonotum covered with dense silver pilosity or strongly sculptured - in macula itself, the only Egyptian species, it is covered with dense pilosity; female foretarsal comb comprised of stronger spines. There is only one species of this group in Egypt.

\section{Prionyx macula (Fabricius, 1804) ssp. macula (s.s.)}

Pepsis macula Fabricius, 1804: 210; holotype $\widehat{\jmath}$ from Saudi Arabia (MNHN, lost?). [Guichard, 1988a.]

Sphex (Harpactopus) Eatoni E. Saunders, 1910: 518-519, §̋,,+ ; holotype $q$ in BMNH; loc. typ. Algeria - Biskra.

Egyptian synonyms:

Sphex (Harpactopus) Eatoni Saunders Honoré, 1942 \& 1944a: 70. Sphex (Priononyx) eatoni Saunders de Beaumont \& Bytinski-Salz, 1955: 41.

Diagnosis: (of females only) (2 females examined.)

Colour: Dark ferruginous [According to the literature, macula is black. In other respects these two specimens fit the descriptions given. I have assumed they are macula, rather than a different species; it is possible they represent a variant colour form similar to Ammophila haimatosoma sinaitica.]. Very dense silver appressed pubescence totally obscuring the sculpture of the following areas: basal half of the clypeus, vertex (there is a band without this pubescence between the eyes including the ocelli), temples above joining the vertex (the lower part of the temples are without this pubescence), dorsal surface of the pronotum, not extending to the 
tubercles or sides, mesonotum (in one specimen examined, that with no data label, the pubescence of the mesonotum is tawny not silver - this may perhaps be due to some form of staining), anterior half of the tegulae. A few short dark hairs on the scape, particularly apically; some short dark semi-decumbernt hairs on the dorsal surface of the propodeum; long dark ferruginous hairs on the clypeus, temples, coxae, trochanters and femora 1 beneath (for other leg vestiture, see morphology section). Wings infuscated, brown colour, except the apical half and the posterior part of the hindwings.

Morphology: mandibles bidentate; clypeal margin entire, mesally a little depressed as is the area behind the margin; sculpture of most of the head, pronotum and mesonotum is totally obscured; lower part of the temples smooth and shining, with a few scattered punctures; sides of the pronotum striate, finely above and coarsely by the coxae; tegulae with the posterior half smooth and shining; scutellum with a median impression, longitudinally striate, anteriorly the striae curve in to the midline; each side with a diagonal carina, closer together anteriorly curving outwards posteriorly; metanotum raised mesally, irregularly transversely striate; propodeum with fine transverse striae, which are rather irregular anteriorly mesally; metapleurae striate each with a deep channel to receive the hind femur; mesopleurae, rounded, widely but irregularly striate. Legs 1 - coxae coarsely striate externally; femora with carina beneath bearing the long dark hairs, above with stouter semi-decumbent hairs; tibiae and tarsi with strong comb of stout spines both sides, intermingled with fine hairs and short spines. Legs 2 \& 3 - femora with semi-decumbent stiff hairs above; tibiae and tarsi with spines and hairs intermingled. Wings with SMC2 narrowed anteriorly. Length: 33-36 mm

Range: Algeria, Egypt, Israel, Kuwait, Saudi Arabia, Iraq, Iran

Distribution: Helwan. Sinai - Wadi Hanzal, Wadi Mitla

Flight: males (4), females $(5,7)$

Collections: PPDD

\section{niveatus species group}

The niveatus species group ( = Calosphex) may be distinguished by the combination of the following chararacters: tarsal claws with two teeth; metapleuron with channel for receiving the hind femur; male antennae without placoids; female clypeal margin entire; Egyptian species with red abdomen and the tergites with a pale apical margin.

Key to the Egyptian species [excluding senilis (Morice)]:

1 SMC2 not narrowed anteriorly (on RS); tarsi 1 with dark pilosity; petiole shorter nigropectinatus (Taschenberg)

- SMC2 clearly narrowed anteriorly (on RS); tarsi 1 with pale pilosity; petiole longer niveatus (Dufour)

\section{Prionyx nigropectinatus (Taschenberg, 1869)}

Sphex nigropectinata Taschenberg, 1869: 409, ; loc. typ. Sudan - Khartum (MLUH). [Kohl, 1885 \& 1890; Guichard, 1988a.]

Egyptian synonyms: Sphex (Calosphex) nigropectinatus Roth, 1925; Honoré, 1942 \& 1944a: 62. Prionyx nigropectinatus de Beaumont \& Bytinski-Salz, 1955: 41; Bohart \& Menke, 1976.

Diagnosis: No specimens seen

Range: Obok, Sudan, Algeria, Egypt, Aden, Iran, ? India

Distribution: Wadi Morrah

Prionyx niveatus (Dufour, 1853) ssp. niveatus (s.s.)

Sphex niveata Dufour, 1853: 377, ơ; loc. typ. Algeria - Ponteba (MNHN). [Kohl, 1885 \& 1890; Guichard, 1988a.]

Egyptian synonyms: Sphex niveatus Sphex (Calosphex) niveatus

Morice, 1911; Storey, 1916.

Prionyx niveatus

Roth, 1925; Honoré, 1942 \& 1944a: 60; de Beaumont, 1966; Pulawski, 1964: 65. Bohart \& Menke, 1976. 
Diagnosis: (13 males and 17 females examined.)

Males: Colour - head and thorax black, except: clypeus with apical yellow band, middle of mandibles yellowish brown, apex of underside of scape yellowish brown, tegulae brownish. Abdomen with petiole black; T1 black, yellow laterally and apically; remaining tergites black basally (this is often concealed by the preceding tergite), yellow red mesally and apically decoloured or yellow; sternites almost completely yellow or red. Legs with tarsal claws ferruginous. Dense silver appressed pubescence masking sculpture on clypeus, scape, frons, vertex (less dense), temples and thorax; also on legs becoming less dense on tarsi; often also on petiole, T1 and T2; longer white hairs on clypeus, temples and pronotum, a few scattered elsewhere on thorax; as usual pubescence is often lacking in worn specimens. Wings hyaline; veins yellow brown. Morphology - sculpture of the head and thorax is usually totally obscured by the pubescence; clypeal lamina straight or broadly emarginate - in very small specimens the margin is convex; clypeus with a few scattered punctures, otherwise matt; Ant3 $>$ Ant5 and wider apically than basally; POL > OOL; mesonotum densely but finely punctate and matt; scutellum bilobate; SMC2 distinctly narrowed on radius - in very small specimens it is triangular. Length: 8-18 mm.

Females: Colour - head and thorax black, except: mandibles ferruginous in basal half, labrum red, scape ferruginous, tegulae ferruginous, legs ferruginous but middle and hind femora black in basal half. Abdomen red with yellow bands apically, the yellow often little more than decoloured; the petiole may be dark. Dense silver appressed pubescence on head, thorax and petiole and legs to femora where it is less dense; long white hairs especially on clypeus, temples, pronotum and posterior and lateral areas of the propodeum. Tarsal comb pale. Wings hyaline; veins light brown. Morphology - clypeal margin entire; disk with fine scattered punctures; Ant3 $>$ Ant5 and apically wider than at base; POL subequal to OOL; scutellum bilobate; dorsal surface of propodeum finely transversely striate; metapleurae with channel; tarsal comb comprised of numerous fine hairs; petiole more or less equal in length to Ant 3+4; SMC2 narrowed on radius. Length: 14-21 mm.

Range: Spanish Sahara, Morocco, Algeria, Libya, Egypt, Sudan, Israel, Turkey, Saudi Arabia, Oman, Iran, sw USSR

Distribution: Abu Rawash, Amrieh, Fayyum (Karanis), Gebel el Asfar, Kerdasa, Kom Awshim, Massarah, Mersa Matruh, Nile valley, Km 94 Suez road, Wadi Digla, Wadi Hoff, Wadi Natrun, Za'afarana road $101 \mathrm{~km}$ E of El Korimat

Flight: males (4-8), females (4-7, 9-11)

Collections: AM, CGR, WJP

\section{Prionyx senilis (Morice, 1911)}

Sphex (Calosphex) senilis Morice, 1911: 75-76, ô, of; loc. typ. Algeria - Biskra (OUM).

Egyptian synonyms: Sphex (Calosphex) senilis Honoré, 1942.

Diagnosis: No specimens seen

Range: N. Africa, Saudi Arabia

\section{Prionyx sp.}

In coll. CUE there is a 9 of the niveatus species group which does not seem to fit the description of any of the recorded species.

Diagnosis: (one female seen)

Colour: head black, except scape and mandibles ferruginous, the latter darker apically; thorax black, except ferruginous tegulae; abdomen with the petiole black and the remainder dark red with lateral and apical pale bands; T2 is somewhat dark mesally at the base; legs red, the middle and hind femora dark; pubescence as in niveatus; tarsal comb with brown hairs; wing veins darker brown than in niveatus, especially the subcosta and media.

Morphology: clypeal margin entire; petiole $<$ Ant3+4; scutellum slightly bilobate; dorsal area of propodeum finely transversely striate. Length: $14 \mathrm{~mm}$.

Distribution: Sinai - Wadi el Lega

Flight: female (8)

Collections: CUE 
stschurowskii species group

This species group ( = Harpactopus in part) shares the following characters with the crudelis and macula species groups: tarsal claws with two teeth; abdomen black and globular. It shares with the macula species group the following characters: male Ant3 clearly shorter than Ant5; male antennae with curved placoids, the placoid-bearing flagellomeres thicker and longer than the others; female clypeus without a distinctly limited mesal emargination, often more or less depressed before the emargination. It may be distinguished from the macula group by the following characters: tibiae without spinules between the spines; SMC2 quite narrow, its sides parallel; recurrent veins more or less interstitial; black pilosity abundant on the thorax; male without expansions on posterior angles of S6; female mesonotum and scutellum shining; female foretarsal comb formed by long spines. There is only one species of this group in Egypt.

\section{Prionyx stschurowskii (Radoszkowski, 1877) ssp. hyalipennis (Kohl, 1895)}

Sphex Stschurowskii Radoszkowski, 1877: 7,, ; loc. typ. Turkestan - Kizil-Kum desert (ZMMU). [Kohl, 1885 \& 1890.]

Sphex (Harpactopus) Stschurowskii var. hyalipennis Kohl, 1895: 47-48, fig., + ; loc. typ. Algeria (NHMW).

Egyptian synonyms: Sphex stschurowskyi (?) Morice, 1897a.

Sphex (Harpactopus) Stschurowskii var. hyalipennis Roth, 1925, Honoré, 1942, Honoré, 1944a: 72, Giner Marí, 1947: 19.

Diagnosis: (a male specimen seen)

Colour: black; silver appressed pubescence on the clypeus and frons; all other pilosity black, including erect hairs on the clypeus and frons; wings hyaline, infuscated base of the costal cell and apically; veins black.

Morphology: (Antennal characters not known as the antennae were broken on the only specimen seen); clypeus pronounced, curved in profile with the apex truncate; deep longitudinal impression mesally above the margin; pronotum with mesal depression; mesonotum with mesal longitudinal depression in anterior half; punctate with the punctures tending to form striae; scutellum rounded, punctate; metanotum without median tubercle; propodeum densely punctate, almost granulate, both dorsally and laterally; mesopleurae densely punctate, almost granulate; tarsal claws with 2 teeth; 1st recurrent vein interstitial between SMC1 \& SMC2; 2nd recurrent vein received in SMC3, almost interstitial; the subcosta and the basal vein markedly thicker than the others; petiole short, subequal to hind tarsomere 2 in length; T1 inserted at right angles. Length: $23 \mathrm{~mm}$.

One specimen examined

Range: Spanish Sahara, Algeria, Tunisia, Libya, Egypt, Israel, Saudi Arabia, Iraq

Distribution: Abu Rawash, Aboukir, Burg el Arab

Flight: male $(4,5)$

Collections: AM, CUE

\section{Sphecini}

\section{Sphex Linnaeus, 1758}

Species of the genus Sphex have a combination of the following characters: a petiole consisting only of S1; a complete spiracular groove on the propodeum; the basal veinlet of the second submarginal cell shorter than or equal to the length of the anterior veinlet (i.e. the cell is square or wider than high); tarsal claws with two basal teeth; the first recurrent vein received by the second submarginal cell or interstitial between 2 and 3; male antennae with placoids; female foreleg with a well developed rake.Members of this cosmopolitan genus nest in the ground, often gregariously. Their prey is composed of crickets and grasshoppers (Orthoptera - Gryllidae, Gryllacrididae and Tettigoniidae).

Key to species recorded from Egypt and Sinai:

Males (excluding $S$. ? lanatus)

1 Abdomen black

- $\quad$ Abdomen red, at least in part 
2 Wings dark; (length 20-22 mm.; placoids on Ant 7-8), wider than those of flavipennis)

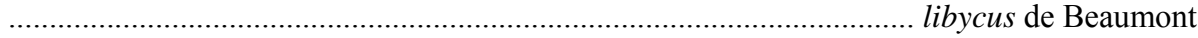

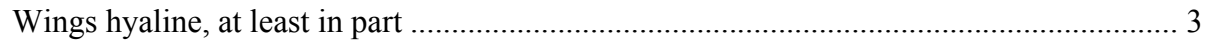

3 Wings hyaline, apically infuscate; dorsal area of propodeum transversely ridged pruinosus Germar Wings hyaline with dark basal spots; dorsal area of propodeum not transversely ridged .. 4

$4 \quad$ Pilosity on clypeus and frons white fumicatus Christ

- Pilosity on clypeus and frons black taschenbergi Magretti rufocinctus Brullé

Females

1 Propodeum covered with long shaggy white hair completely covering the surface; (in the only specimen seen, the hairs are tinged with orange - ? stained) ? lanatus Mocsáry

- $\quad$ Propodeum without long shaggy white hairs 2

2 Dorsal area of propodeum with 7 or 8 transverse ridges, clearly visible beneath the white pubescence which covers the thorax pruinosus Germar

- Dorsal area of propodeum finely transversely striate without clearly visible ridges ... 3

3 Wings hyaline, basal dark marks, apex of anterior wings infuscate 4

- Wings more or less yellow or completely infuscate without basal darker marks 5

$4 \quad$ Pilosity on clypeus and frons white fumicatus Christ

- $\quad$ Pilosity on clypeus and frons black taschenbergi Magretti

$5 \quad$ Abdomen black libycus de Beaumont Abdomen red, at least in part ...... 6

6 Wings yellowish grey, apical part paler; clypeus and frons covered with silvery pubescence; mesonotum without fine transverse striation; thorax never with red markings; length 20-26 mm. rufocinctus Brullé

- Wings distinctly yellow, apex darker; frons covered with generally golden pubescence; mesonotum with fine transverse striation; thorax sometimes with red markings; length 29-33 mm. flavipennis Fabricius

\section{Sphex flavipennis Fabricius, 1793}

Sphex flavipennis Fabricius, 1793: 201; lectotype $\circ$ from Italy (ZMK) [Kohl, 1885 \& 1890; Guichard, 1988a.]

Egyptian synonyms:

Sphex flavipennis

Sphex (s.str.) flavipennis

Storey, 1916.

Honoré, 1942 \& 1944a: 76.

Diagnosis: No specimens from Egypt seen. Diagnosis made from specimens from Italy (Sardinia).

Colour: Pubescence silver, but on head with golden tinge, particularly the long hairs. This is given by most authors as a character for separating this species from S. rufocinctus, but often it is silvery, but perhaps it is more obviously golden on fresh specimens. Wings with yellowish tinge, the apices infuscate. Veins light brown. Male: black, with the following red: mandibles (black at apex); T1-3 (T3 has irregular black triangular mesal area reaching posterior margin); S1 (petiole black), S2 \& S3; legs (dark ferruginous). Female: black, with the following red: mandibles (black at apex); tegulae; T1-3, with some irregular areas at the base of T4; S1 (petiole black), S2, S3 and some basal spots on S4; femora 1, basal spot on exterior surface, apical half, more widespread on interior surface; all tibia and tarsi.

Morphology: Male - clypeus with apical margin straight, some scattered punctures over a microsculpture on disk, dull; antennae with placoids only on T7 and T8; mesonotum punctate, with weak transverse striations, not always easily visible; petiole subequal in length to Ant5; S7 
with shorter, sparser hair tufts than S. ruficinctus; length $20 \mathrm{~mm}$ (usually given as $16-22 \mathrm{~mm}$ ). Female - clypeal margin convex, the disk without appressed pubescence, one or two punctures over a microsculpture; Ant 3 wider apically than in basal half; scutellum and metanotum with median impression; propodeum finely transversely striate; petiole subequal in length to hind tarsomere 3; length $27 \mathrm{~mm}$. (usally given as $25-32 \mathrm{~mm}$.)

Range: France, Italy, Algeria, Libya, Egypt, Israel, Turkey, Afghanistan

Distribution: Kerdassa, Saqqara

\section{Sphex fumicatus Christ, 1791 ssp. fumicatus (s.s.)}

Sphex fumicatus Christ, 1791; 295; type lost; loc. typ. unknown. [van der Vecht, 1973; Guichard, 1988a.]

Sphex metallica Taschenberg, 1869: 414, Ō, $\bigcirc$; syntypes from Khartoum, Sudan (MLUH) [Kohl, 1890]

Egyptian synonyms:

Sphex umbrosus Christ, $1791 \quad$ Storey, 1916.

Sphex (s.str.) umbrosus Honoré, 1942.

Sphex (s.str.) umbrosus metallicus Honoré, 1944a,

Sphex umbrosus metallicus Christ (sic) de Beaumont, 1956a

Sphex umbrosus is believed to be a junior synonym of the oriental species S. argentatus Fabricius, 1787. Through a very old misidentification the name has been misused for African, east Mediterranean, west and south Asian species. Taschenberg described the form which is in the Egyptian fauna as Sphex metallicus. Later authors made this a subspecies of umbrosus. Van der Vecht, 1973 synonymised metallicus Taschenberg with fumicatus.[I am not convinced of this last synonymy. Apart from the clypeal hair colour, there seem to be different number of foretibial spurs. DB Baker tried to get the type sent to me at the BMNH from MZUB, but it was already on loan. See also Leclercq's paper on the African spp with infuscated forewings]

Diagnosis (29 males and 15 females examined.)

Colour: Black, except the legs may be ferruginous to a variable extent, particularly the hind legs, to a lesser extent the middle ones, while only occasionally are the fore-tibiae ferruginous. The mandibles of the female are dark and dull but ferruginous at the base. The frons and clypeus are covered with dense silver pubescence not reaching the apex of the clypeus. Additionally, there are long erect silver white hairs. In the female there may be a golden or pale brown tinge. The vertex and temples have long silver or pale brown erect hairs. Pronotum, mesonotum and scutellum with shorter pale hairs. Propodeum and mesopleurae with brown or black hairs.

Abdomen with a silver pruinosity, the apical segments with longer pale hairs. The wings are hyaline with a dark patch basally reaching the medial and submedial cells. The apex is infuscate, but not as dark as the basal patch.

Morphology: Males - antennae gradually thicker until Ant12; Ant13 narrows almost to a point; Ant3 curved, narrower basally than apically and longer than Ant4; placoids from the apex of Ant3 to Ant8, sometimes extended to Ant9 and beyond, but reduced to a longitudinal carina; apical margin of the clypeus broadly emarginate; mesonotum and scutellum densely punctate; metanotum bilobate; dorsal surface of propodeum transversely striate, lateral surfaces sparsely punctate; mesopleurae densely punctate with microsculpture beneath; petiole (S1) about the same length as hind tarsomere 2. Length: 16.5 - $27 \mathrm{~mm}$. Females - antennae with Ant3 almost as long as Ant3 \& Ant4 together; clypeus slightly convex, its anterior margin entire; mandibles stout and strong with a marked tooth internally; mesonotum finely but densely punctate, matt; scutellum convex, punctate similarly to the mesonotum, with a median impression; metanotum bilobate; dorsal surface of the propodeum densely striate, lateral surfaces dull, punctate with some striae; metapleurae scarcely punctate; mesopleurae finely punctate, shining; petiole (S1) very short, shorter than half the length of the hind femur; legs robust; foretarsal comb with 9-10 stiff spines. Length: 24 - $28 \mathrm{~mm}$.

Range: Whole Africa to Cape, Cyprus, e.Mediterranean, Aden, Socotra, Pembas, w. and s. India, Sri Lanka, Israel, Oman. The range given by authors under the name umbrosus Christ must be treated with caution as this name is correctly used as a synonym of argentatus Fabricius, 1787, an oriental species.

Distribution: Aswan, Ezbet el Nakhl, Fayyum (Tamyah), Gebel el Asfar, Giza, Kerdasa, Khattara, Kom Awshim (= Fayyum in Coll. Mochi), Maadi, Marg

Flight: males (1, 7-10), females (1, 6, 8-10)

Collections: AM, CGR, CUE 


\section{Sphex funerarius Gussakovskij, 1934}

Sphex funerarius Gussakovskij, 1934: 3, ð,,, ; lectotype $\lesssim$ from China (NRS), designated by Menke \& Pulawski, 2000: 333

Sphex maxillosus Fabricius 1793: 208; (nec Brullé, 1833). [Kohl, 1885 \& 1890]. Synonymised by Menke $\&$ Pulawski, 2000: 332

Sphex rufocinctus Brullé, 1833: 367, đึ; holotype đ̂ from Greece, in MNHN, synonymised with maxillosus by Kohl, 1890: 433

Egyptian synonyms:

Sphex maxillosus

Sphex (s.str.) maxillosus

Kohl, 1885.

Honoré, 1942 \& 1944a.

Diagnosis: (from one Egyptian male, one Italian (Sardinian) male and one Sardinian female.)

Colour: black, except for the following. Red areas are: T1-3 (sometimes the tergites are dark basally; in the Egyptian male examined T3 is dark apically; in the Sardinian female examined the red extends to T4 and the base of T5); S1 (after the petiole) - S3 (in the Egyptian male examined, S3 is dark apically; the Sardinian female has the base of S4 also red). (The legs after the base of the femora in the Sardinian female are bright red.) Dark ferruginous areas are: mandibles; tegulae (not in the Sardinian specimens); tibiae and tarsi of the male. Pubescence, both the appressed on the clypeus and frons, and the erect on the head and thorax is silver. Wings are slightly infuscate giving a grey appearance, with at most only a slight yellow tinge. Veins brown, the costa and subcosta darker.

Morphology: Male - clypeal margin slightly but distinctly and broadly emarginate, the disk with scattered punctures over a distinct microsculpture; antennae with placoids on Ant 5-9; Ant 3 slightly wider apically than basally; mesonotum densely punctate without trace of transverse striations; propodeum finely but irregularly striate, with punctures between; petiole subequal in length to hind tarsomere 2; S7 with hair tufts a little longer than in S.flavipennis. Length $22 \mathrm{~mm}$ (Generally given in the literature as 15 - $19 \mathrm{~mm}$ ). Female - (from Sardinian specimen) clypeal margin mesally straight, the disk shining with scattered punctures without a distinct underlying microsculpture; vertex and mesonotum with widely spaced punctation, the spaces greater than the diameter of the punctures; scutellum and metanotum with slight mesal longitudinal impression; dorsal area of propodeum dull with transverse striae and punctures between; petiole subequal in length to hind tarsomere 2. Length - (in the literature, $16-22 \mathrm{~mm}$ )

Range: S.Europe, Crete, Algeria, Libya, Egypt, Israel, Turkey, S.Asia to China

Distribution: Sinai, Wadi Genah (St Catharine's) (Quite common in the semi-desert zone - per Honoré)

Flight: male (7) (May and June per Honoré)

Collections: SZ

\section{Sphex ? lanatus Mocsáry, 1883}

Chlorion (Proterosphex) umbrosum var. lanatum Mocsáry, 1883:34, ô. [Arnold, 1928b.] Egyptian synonyms:

In coll AM there is a specimen from Gebel Elba which keys to this species in Arnold (1928b). Its usual range is S. Africa, Rhodesia, Zaire and Tanzania. I have tentatively determined it as such but with a certain doubt as Arnold's key indicates that the posterior femora and tibiae are black, whereas in this specimen they are dark ferruginous.

Diagnosis (1 female examined)

Colour: Black, except mandibles and legs dark ferruginous; silver appressed pubescence dense on clypeus and frons to anterior ocellus, less densely on scape, temples, posterior margin of pronotum, three longitudinal stripes on the mesonotum (one on each lateral margin and a short one mesally), petiole; long white hairs on clypeus, frons, scape, vertex (sparse); shorter white hairs on pronotum, sparse on anterior of mesonotum, mesopleurae and mesosternum; propodeum with very long shaggy white hairs, with an orange tinge, totally obscuring the sculpture; the orange tint may be due to staining; tergites with white pruinescence, less apically; wings hyaline, infuscated basally and apically; veins black, apically brown;

Morphology: clypeal margin a regular arc, with a slight emargination; Ant 3 curved, shorter than Ant 4+5; Ant 12 truncate; vertex with a few scattered punctures; mesonotum closely and finely punctate; scutellum rounded with median impression; metanotum bituberculate; metapleurae with channel, smooth and shining; mesopleurae and mesosternum finely punctate; petiole short, subequal to hindtarsomere 2; tergites 3-5 punctate except a shining apical margin, this wider 
mesally; T6 entirely punctate; forelegs with a strong comb; metatarsus with 4 thick spines on the anterior margin and about 8 thinner ones posteriorly; SMC2 triangular.

Range: S Africa, Rhodesia, Zaire, Tanzania, Egypt (?)

Distribution: Gebel Elba (Wadi Aideb)

Flight: female (1)

Collections: AM

\section{Sphex libycus de Beaumont, 1956}

Sphex (s.s.) libycus de Beaumont, 1956a: 182-183; 0 , + ; type in BMNH; loc. typ. Libya, Tripolitania (Leptis Magna).

\section{Egyptian synonyms:}

Sphex libycus

de Beaumont, 1960a.

Diagnosis: (6 males and 4 females examined.)

Colour: Black, except dark ferruginous on the mandibles (black apically) and apical part of tibiae; clypeus and frons with silver appressed pubescence (the disk of the clypeus without pubescence); longer erect hairs on head and thorax brownish; abdomen with a rusty pruinescence; wings uniformly infuscated.

Morphology: Males - clypeus somewhat swollen with apical margin entire and convex; placoids on Ant7 \& 8; head and thorax punctate over a microsculpture; scutellum rather swollen with a median longitudinal impression; metanotum also swollen but without an impression; dorsal area of propodeum finely but irregularly transversely striate; in dorsal view, petiole subequal in length to hind tarsomere 3; abdomen shining. Length: $18-22 \mathrm{~mm}$. Females - as male except metanotum with an impression; sculpture of the dorsal area of the propodeum finer. Length: 26 $\mathrm{mm}$.

Range: Libya, Egypt

Distribution: Amriyeh (near Alexandria), Burg el Arab

Flight: males $(4,6,8)$, females $(4,6)$

Collections: AM, CUE

\section{Sphex pruinosus Germar, 1817}

Sphex pruinosa Germar, 1817: 261, ठ̋; whereabouts of the type is unknown; loc. typ. Dalmatia Spalato. [Kohl, 1885 \& 1890; Guichard, 1988a.]

\section{Egyptian synonyms:}

Sphex pruinosus

Sphex (s.str.) pruinosus

Storey, 1916.

Honoré, 1942 \& 1944a; Pulawski, 1964.

Diagnosis: (54 males and 9 females examined.)

Colour: Wings hyaline, infuscate apically, the veins black or dark brown, except the costa and subcosta of the female red-brown. Males - black; often abdomen dark ferruginous basally, particularly the sternites; legs also may be dark ferruginous; frons and clypeus with dense silver appressed pubescence and longer white hairs intermingled; vertex, occiput and temples with dense silver appressed pubescence, particularly on the temples, and with scattered long white hairs; silver appressed pubescence on pronotum and laterally on mesonotum; mesopleurae with long white hairs and patches of silver appressed pubescence; propodeum densely covered with silver appressed pubescence and longer white hairs, often obscuring the sculpture; sometimes, posteriorly the hairs have a slight golden tinge; coxae with silver pubescence; petiole (S1) with silver pubescence and some longer white hairs; gaster with silver pruinosity. Females - black, with the following red: mandibles, black apically sometimes a narrow band on the apical margin of the clypeus, scape, tegulae, petiole (sometimes black), T1-3 or 4 basally and S2-4; in one example, the entire abdomen after the petiole is red; femora (dark basally and posteriorly) and tibiae; the tarsi are darker. Pubescence and pilosity of the head and thorax as the male, except there is no golden tinge on the propodeum and the gaster sometimes lacks the pruinosity.

Morphology: the dorsal surface of the propodeum in both sexes has a few transverse ridges, clearly visible beneath the pubescence; this is more marked in females; sometimes it is necessary to get the correct angle to see. Males - clypeus apically truncate or slightly emarginate; when visible, through the pubescence, it has scattered punctures on a base of microsculpture; antennae with placoids from Ant5 to Ant8; Ant4 and Ant9 onwards have a carina alongside a flattened area; mesonotum finely punctured over a basic microsculpture; scutellum and metanotum rounded, with a median depression, more noticeable on the scutellum; propodeum with transverse ridges 
and transverse striae between; mesopleurae with scattered punctures over a microsculpture base; petiole (S1) slightly longer than tarsomere 2 of the hind leg. Length - $12-19 \mathrm{~mm}$. Females clypeal margin sometimes entire, sometimes notched or mesally emarginate; Ant4 to Ant7 longitudinally carinate, as though with placoids; sculpture of the thorax similar to that of the male; femora 1 with the external surface below shining and above dull. Length - $16-20 \mathrm{~mm}$.

Range: Mediterranean area to Ethiopia, Spanish Sahara, Algeria, Libya, Egypt, Sudan, Italy (Sicily), Crete, Israel, sw USSR, Oman, Burma

Distribution: Abu Rawash, Abu Zabal, Baharia Oasis (El Aguz), Ezbet el Nakhl, Fayyum (Karanis, 26km w of Shakshuk), Gebel el Asfar, Giza, Giza - Pyramids, Kerdasa, Kom Awshim, Saqqara, Tisfa, Wadi Hagul. Sinai - $10 \mathrm{~km}$ E of El Arish, Wadi el Lega

Flight: males (1-2, 5-12), females $(1,5-7,10)$

Collections: AM, CGR, WJP, CUE, SZ

\section{Sphex taschenbergi Magretti, 1884}

Sphex Taschenbergi Magretti, 1884: 61, q; type from Ethiopia, in MSNG. [Kohl, 1890.]

Egyptian synonyms:

Sphex (s.s.) umbrosus taschenbergi de Beaumont, 1956a.

This may be merely a subspecies, or more likely, a variety of S. fumicatus - the differences between them are minimal.

Diagnosis:

De Beaumont (1956a: 182) distinguishes this species from S. fumicatus only by the erect pilosity on the head and thorax being entirely black, whereas in fumicatus it is white on the clypeus and frons. The collection of the University of Cairo has such an individual with black erect pilosity. When this specimen was referred to Mr K.M.Guichard for his opinion, he determined it as fumicatus, not considering that the variant hair colour was enough to warrant it being referred to a separate species. This individual is the source of the diagnosis below. Pending further information about taschenbergi, this diagnosis must be considered provisional. The distribution data of this specimen is enclosed below in square brackets.

Colour: Male - black, except hindlegs dark ferruginous, which are brighter than in fumicatus; erect pubescence of head and thorax entirely black; clypeus and frons with silver appressed pubescence; wings infuscate, the apices less so; veins dark brown or black.

Morphology: clypeal margin broadly emarginate over whole width; surface concealed beneath the appressed pubescence; antennae missing (this is unfortunate as the placoids might have given a distinguishing feature); scutellum and meatanotum with a median longitudinal impression, less marked than in fumicatus; propodeum finely transversely striate, less marked than in fumicatus; petiole greater in length than hind tarsomere 2; apical sternites, seen in profile, with less evident hair than fumicatus. Length: male $21 \mathrm{~mm}$.

Range: Libya, Egypt, Sudan, Chad, Ethiopia, s.Arabian peninsula

Distribution: Aswan, [Tisfa]

Flight: male [6-9]

Collections: [CUE]

\section{CRABRONIDAE}

\section{ASTATINAE}

Astata Latreille, 1796

boops species group

Astata boops (Schrank, 1781) ssp. boops (s.s.)

Sphex Boops Schrank, 1781: 384, ô; type lost; loc. typ. Austria - Prater = Vienna. [Pulawski, 1975.]

\section{Egyptian synonyms:}

In coll. CGR; a new record from Egypt. 
Range: Europe, Algeria, Libya (Cyrenaica), Egypt, Turkey, Oman, w. Asia, India Distribution: Kerdasa

Flight: males (7)

Collections: CGR (first record from Egypt)

\section{Astata cleopatra Pulawski, 1959}

Astata cleopatra Pulawski, 1959: 372-378, §̊,, ; holotype 9 in coll. WJP; loc. typ. Egypt - Fayum, Kom Awshim.

Egyptian synonyms: Astata cleopatra

Pulawski, 1959 \& 1973; Bohart \& Menke, 1976;

Range: Egypt, Oman

Guichard, 1980.

\section{Astata fumipennis E. Saunders, 1910}

Astatus fumipennis E. Saunders, 1910: 519-520, $q$; holotype $q$ in BMNH; loc. typ. Algeria Biskra.

Egyptian synonyms:

Astata fumipennis Honoré, 1942.

Range: Algeria

\section{Astata laeta E. Saunders, 1910}

Astatus laetus E. Saunders, 1910: 520, §,,+ ; holotype $q$ in BMNH; loc. typ. Algeria - Biskra.

Egyptian synonyms:

Astata laeta

Honoré, 1942.

Range: Morocco, Algeria, Tunisia

miegi species group

\section{Astata lubricata Nurse, 1903}

Astata lubricata Nurse, 1903: 514, §ิ, + ; lectotype $q$ in BMNH; loc. typ. India - Bombay State, Deesa. [Pulawski, 1975.]

Astata eremita Pulawski, 1959: 349-361, đ̊; holotype $\widehat{\jmath}$ in coll. WJP; loc. typ. Egypt - Gebel Elba. Wadi Eideb. Pulawski, 1975, synonymised eremita with lubricata.

\section{Egyptian synonyms:}

Astata eremita

Astata lubricata

Range: Egypt, Oman, w.India

Distribution: Mersa Matruh

Flight: females (6)

Collections: CGR
Pulawski, 1959.

Pulawski, 1975; Bohart \& Menke, 1976; Guichard, 1980.

\section{Astata radialis E. Saunders, 1910}

Astatus radialis E. Saunders, 1910: 521, đ,,+ (?); holotype $\odot$ in BMNH; loc. typ. Algeria - [Le Tarf or Bône]. E. Saunders was not sure that the sole $\delta$ that he saw was conspecific with his new species.

Egyptian synonyms: Astata radialis

Honoré, 1942.

Range: Spanish Sahara, Morocco

Diploplectron Fox, 1893

\section{Diploplectron palearcticum Pulawski, 1958}

Diploplectron palearcticum Pulawski, 1958: 473-476, ठิ,,+ ; holotype $q$ in coll. Alfieri in AUCE; loc. typ. Egypt - Sinai, Wadi Mitla.

Egyptian synonyms: 
Diagnosis: (3 females [one without head or abdomen] examined.)

Female: Colour - black, except the following areas: mandibles ferruginous, darker apically; sometimes underside of antennae dark brown; tegulae yellow; tibiae and tarsi brown, apex of femora 1 and base of tibia 1 paler. Wings hyaline, veins yellow. Morphology - mandibles without externoventral notch; clypeal margin tridentate; distinct malar space; eyes convergent towards vertex; head smooth, impunctate, shining; Ant 1 thick, much thicker than Ant 2 which is itself thicker than Ant 3-12; pronotum. mesonotum and scutellum smooth and shining; scutellum long with quadrangular mesal section which has a longitudinal mesal impression; dorsal area of propodeum granulate, the remainder smooth, laterally one or two weak striae; metapleurae, mesopleurae and mesosternum smooth and shining; T6 without lateral or other hairs, no defined pygidial area; marginal cell short; SMC1 with diagonally transverse uncoloured "vein" visible at some angles (1r); SMC2 triangular; SMC3 very narrow; recurrent vein 1 received by SMC1. Length: $6 \mathrm{~mm}$

Range: Egypt

Distribution: Ben Youssef, Giza, Kerdasa, Kom Awshim, Saqqara, Tell el Amarna

Flight: males (3-5), females $(3-5,12)$

Collections: CGR, WJP

Dryudella Spinola, 1843

tricolor species group

Dryudella amenartais (Pulawski, 1959)

Astata amenartais Pulawski, 1959: 397-402, §̊, + ; holotype $\odot$ in coll. WJP; loc. typ. Kom Awshim. Egyptian synonyms:

Astata amenartais $\quad$ Pulawski, 1959;

Dryudella amenartais Bohart \& Menke, 1976.

Range: Egypt, Turkey, Iran

Dryudella ammochtona (Pulawski, 1959)

Astata osiriaca ammochtona Pulawski, 1959: 391-393, $q$; holotype $q$ in coll. WJP; loc. typ. Egypt - Dakhla Oasis.

Egyptian synonyms:

Astata osiriaca ammochtona Pulawski, 1959.

Dryudella ammochtona $\quad$ Bohart \& Menke, 1976.

Range: Egypt

\section{Dryudella beaumonti (Pulawski, 1959)}

Astata beaumonti Pulawski, 1959: 393-397, ô,,+ ; holotype $\odot$ in coll. de Beaumont in MZL; loc. typ. Morocco - Marrakesh.

Egyptian synonyms:

In coll CGR; the first record from Egypt.

Range: N. Africa, Egypt

Distribution: Mersa Matruh

Flight: males (5)

Collections: CGR (first record from Egypt)

\section{Dryudella bifasciata (Schulthess, 1926)}

Astata bifasciata Schulthess, 1926: 150; §̊, o ; loc.typ. Kairouan, Tunisia (ETHZ, NHMW)

Egyptian synonyms:

Astata bifasciata

Dryudella bifasciata

Diagnosis: (1 male and 4 females examined.)
Honoré, 1942; Pulawski, 1959.

Bohart \& Menke, 1976. 
Males: Colour - head black with mandibles very dark ferruginous, frons with pale yellow transverse spot in form of figure of eight with the anterior ocellus fitting into the upper emargination. Thorax black with pronotal tubercles and tegulae pale yellow. Abdomen with tergites very dark ferruginous, getting darker posterad, T5 \& T6 almost black, T7 very dark ferruginous; T1 and T2 with ivory band, that on T2 divided narrowly into two transverse spots; sternites a lighter ferruginous, especially S2. Legs with coxae, trochanters and femora black, the trochanters with narrow ivory apical ring; apex of femora, tibiae and tarsi light ferruginous. Thorax with scattered short white hairs. Wings hyaline, veins ivory, centre of stigma pale brown. Morphology - clypeus with prominent mesal lobe separated from lateral ones by oblique carinas, narrowed towards the apex, the margin emarginate; malar space wide, about twice the diameter of Ant 3; frons with microsculpture; eyes holoptic [generic character]; Ant 1 a little longer the wide; Ant 2 globular; Ant $3>$ Ant 4; Ant 5-12 curved beneath; Ant 13 pointed; mesonotum finely punctate anteriorly, smooth and shining posteriorly; scutellum rounded, smooth and shining; propodeum with dorsal area granulate anteriorly, becoming smooth and shining posteriorly, laterally punctate over microsculpture; mesopleurae finely punctate over microsculpture; T7 laterally carinate. Length: $4 \mathrm{~mm}$.

Females: Colour - head black except mandibles ferruginous, dark apically, and small ivory spot at apex of Ant 1; thorax black, except pronotal tubercles ivory yellow, tegulae ivory yellow; abdomen dark ferruginous, T6 paler, T1 with ivory yellow band, sometimes mesally divided into two spots, T2 with two ivory yellow transverse spots; legs $1 \& 2$ light ferruginous from apex of femora; Legs 3 darker ferruginous, but apex of femora and base of tibiae light ferruginous. A few scattered long pale hairs on temples, mesopleurae, mesosternum and underside of femora 1. Wings hyaline, the veins ivory yellow. Morphology - frons smooth with microsculpture, particularly in lower half, a slight mesal longitudinal impression; upper frons to behind posterior ocelli with no microsculpture, shining; vertex behind posterior ocelli with microsculpture again; eyes much closer together above; POL > OOL; Ant 1 with stiff hairs on anterior surface, short, length only a little greater than width; Ant 2 globular; pronotum smooth, laterally with some microsculpture; mesonotum smooth and shining, slight microsculpture in anterior part with a few scattered punctures; there is a trace of a mesal longitudinal impression in the anterior part; scutellum and metanotum smooth and shining; propodeum with the dorsal area granulate, posterior and lateral surfaces striate; tibiae 1 with decumbent hairs and several stout spines apically; metatarsi 1 with 6 stout comb spines; mid- and hind-tibiae and tarsi spinose; marginal cell short; SMC1 with stub of 1r; SMC2 triangular; SMC3 narrow. Length: 4-5 mm.

Range: Canary Is., Morocco, Libya (Tripolitania, Cyrenaica), Egypt

Distribution: Kerdasa, Kom Awshim, Mersa Matruh

Flight: males (4), females (4-5)

Collections: CGR

\section{Dryudella elbae (Pulawski, 1959)}

Astata amenartais elbae Pulawski, 1959: 402, $\widehat{\jmath}$; holotype $\widehat{\delta}$ in coll. WJP; loc. typ. Egypt - Gebel Elba.

Egyptian synonyms:

Astata amenartais elbae Pulawski, 1959.

Dryudella elbae Bohart \& Menke, 1976.

Range: Egypt

\section{Dryudella opaca (Pulawski, 1959)}

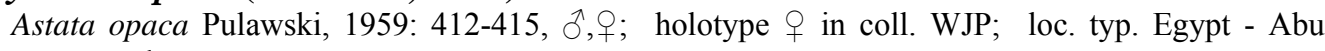
Rawash.

Egyptian synonyms:

Astata opaca

Dryudella opaca

Pulawski, 1959.

Range: Egypt

Bohart \& Menke, 1976.

\section{Dryudella osiriaca (Pulawski, 1959)}

Astata osiriaca Pulawski, 1959:389-391, + ; holotype $q$ in coll. WJP; loc. typ. Egypt - Abydos.

Egyptian synonyms:

Astata osiriaca

Pulawski, 1959. 
Dryudella osiriaca

Range: Egypt

stigma species group

Dryudella nephertiti (Pulawski, 1959)

Astata nephertiti Pulawski, 1959: 382-389, $\widehat{0}, \propto$; holotype + in coll. WJP; loc. typ. Egypt Abydos.

Egyptian synonyms:

Astata nephertiti

Dryudella nephertiti

Range: Egypt

Distribution: Wadi Digla

Flight: females (3)

Collections: CGR
Bohart \& Menke, 1976.

Pulawski, 1959.

Bohart \& Menke, 1976.

\section{DINETINAE}

Dinetus Panzer, 1806

\section{Dinetus cereolus Morice, 1897}

Dinetus cereolus Morice, 1897a: 310, + ; holotype in OUM; loc. typ. Egypt - Cairo.

Egyptian synonyms:

Dinetus cereolus $\quad$ Morice, 1897a; Honoré, 1942; Bohart \& Menke,

Range: Egypt

1976; Guichard, 1980.

\section{Dinetus dentipes E. Saunders, 1910}

Dinetus dentipes E. Saunders, 1910: 530-531, §̂,, ; holotype ${ }^{\Uparrow}$ in BMNH [?]; loc. typ. Algeria Biskra

Egyptian synonyms:

Dinetus dentipes

Bohart \& Menke, 1976.

Range: Algeria, Tunisia, Egypt

\section{Dinetus nabateus de Beaumont, 1960}

Dinetus nabateus de Beaumont, 1960: 268, ${ }^{\lambda}$; holotype ${ }^{\lambda}$ from Feiran Oasis, Sinai (in WJP)

Egyptian synonyms:

Dinetus nabateus Bohart \& Menke, 1976; Guichard, 1980.

Range: Egypt, Oman

\section{Dinetus pulawskii de Beaumont, 1960}

Dinetus pulawskii de Beaumont, 1960: 1960, đ̊,, ; holotype $\widehat{\jmath}$ from Abu Rawash nr Cairo (in WJP) Egyptian synonyms:
Dinetus pulawskii
Bohart \& Menke, 1976.

Range: Egypt 


\title{
PEMPHREDONINAE
}

\author{
Pemphredonini
}

Diodontus Curtis, 1834

Partial Key to Egyptian Species

Males

$1 \quad$ Metatarsi 1 straight; flagellum black

oraniensis

Metatarsi 1 more or less curved; flagellum brown to yellow beneath

2 Metatarsi 1 markedly curved; flagellum darker; dorsal area of propodeum uniformly coarsely sculptured; wing veins dark friesei

- $\quad$ Metatarsi 1 less curved; flagellum yellow beneath; dorsal area of propodeum laterally smooth without coarse sculpture; wing veins pale, only subcosta dark clarus

Females

$1 \quad$ Flagellum yellow beneath; dorsal area of propodeum laterally smooth without coarse sculpture clarus

- $\quad$ Flagellum dark; dorsal area of propodeum uniformly coarsely sculptured 2

2 Mesonotum with microsculpture beneath punctures; flagellar segment 1 longer and more slender ..... oraniensis

- Mesonotum without microsculpture beneath punctures; flagellar segment 1 shorter and thicker .. friesei

\section{Diodontus crassicornis Gribodo, 1894}

Diodontus crassicornis Gribodo, 1894: 23, §̋; holotype $\widehat{\jmath}$ from Tunisia (MCSNG) Diodontus brachycerus Kohl, 1898: 91, ふ̃, , ; type from Orna, Algeria (NHMW). [Kohl, 1901a.]

Egyptian synonyms:

Diodontus brachycerus In coll. AM; a new record from Egypt.

Range: Tunisia, Egypt

Distribution:

Flight:

Collections: AM

\section{Diodontus clarus Pulawski, 1964}

Diodontus clarus Pulawski, 1964: 143-145, đ̊, + ; holotype $q$ in coll. WJP; loc. typ. Egypt - Abu Rawash. 31.iii.1958

Egyptian synonyms:

Diodontus clarus $\quad$ Bohart \& Menke, 1976.

Diagnosis:

Males - Form 1: Colour - black, except: mandibles, pale yellow, the apex ferruginous; Ant1 and Ant2, pale yellow beneath (anteriorly) and darker above (posteriorly); Ant3 - Ant13 light brown beneath and rather darker above; pronotal tubercles pale yellow; anterior part of the tegulae pale yellow, the posterior part decoloured; T6 and T7 ferruginous; legs yellow from the apex of the femora; the posterior surface of the tibiae largely light brown. Silver appressed hair on the clypeus and frons. Wings hyaline, the veins, except for the subcosta which is dark, pale yellow basally but darker apically especially around the marginal cell; the stigma anteriorly brown and posteriorly almost black. Morphology - clypeus flat; frons and vertex with very slight microsculpture and a few scattered punctures; mesonotum shining and impunctate; dorsal area of the propodeum smooth and shining except for a mesal triangle which is lightly rugose; mesopleurae rugose above and smooth below; metatarsi $1 \& 2$ almost completely straight, that of the fore-leg very slightly curved. Length: 3-3.5 mm. 3 examples examined from Abu Rawash, iii.

Form 2: Colour - As form 1 except: Ant1 and Ant2 are black beneath (anteriorly); Ant3 Ant13 are very much darker above (posteriorly) than in Form 1; T6 and T7 are extremely dark 
ferruginous, almost black; posterior surfaces of tibiae are only slightly tinged with brown. Morphology - frons and vertex are without microsculpture but have finer and denser punctation than Form 1; metatarsi 1 a little more curved than in Form 1; metatarsi 2 only very slightly curved, virtually straight. Length: 3.5-4 mm. 4 males examined from Wadi el Natrun, iii.

Form 3: Colour - as Form 1, except: Ant1 \& 2 black; Ant3-12 light brown beneath but each flagellomere is separated from the next by a dark line; Ant 13 darker; the upper side is darker as usual; T6 \& T7 are scarcely ferruginous; tibiae $1 \& 2$ are light / red brown in the middle of the posterior surface; the apical half of Tibiae 3 is a darker brown all round the segment. Morphology - frons and vertex with distinct microsculpture and numerous fine but spaced punctures; mesonotum shining and sparsely finely punctate; metatarsi 1 more curved than in Form 2, but nothing like as much as in D. friesei; metatarsi still virtually straight. Length: 3-4 mm. 5 examples examined from $65 \mathrm{~km} \mathrm{~W}$ of El Arish, N.Sinai, iv.

Females: Colour - black, except: mandibles pale yellow with ferruginous apex; Ant2 - Ant12 light brown beneath, darker above; pronotal tubercles pale yellow; tegulae anteriorly pale yellow, posteriorly decoloured; T6 scarcely tinged with ferruginous; legs - apex of femora and base of tibiae pale yellow, then yellow brown. Wings hyaline; veins ivory at base, then light brown except subcosta, stigma and the veins around the marginal cell dark. Morphology - very shining, without microsculpture; frons and vertex with a few scattered and very fine punctures; mesonotum and scutellum impunctate; sides of propodeum striate; mesopleurae rugose above and smooth below. Length: $4 \mathrm{~mm}$. 1 example seen from Wadi Digla, iv.

Range: Egypt

Distribution: Abu Rawash, Saqqara, Wadi Digla, Wadi el Natrun. Sinai - $65 \mathrm{~km}$ W of El Arish

Flight: males (3-4), females (3-4)

Collections: CGR, WJP

\section{Diodontus hyalipennis Kohl, 1892}

Diodontus hyalipennis Kohl, 1892: 204, ; ; holotype $\odot$ from Baku, Azerbaijan (NHMW) Diodontus friesei Kohl, 1901: 121-122, §ิ,+; syntypes from 'Egypt' \& Tunisia (NHMW); synonymised by Budrys in Nemkov et al 1995: 399.

Egyptian synonyms:

Diodontus friesei

Diodontus Friesei

Kohl, 1901; Pulawski, 1964.

Diagnosis: (49 males and 25 females examined.)

Males: Colour - black, except: mndibles yellow, ferruginous to black apically; plps yellow; antennae - 1-2 black; 3-13 light brown varying to dark brown beneath, dark above, the apical segments darker - it is always dark between the segments; pronotal tubercles ivory; tegulae, the anterior half pale yellow and the posterior half ferruginous or decoloured; T6-7 dark ferruginous, sometimes also the sternites; in one specimen examined the apex of the abdomen was black; legs 1-2 yellow from the apex of the femora, the tibiae with brownish stripe on posterior surface; legs 3 yellow from apex of femora but apical half of the tibiae dark brown; in one example seen the hind tibiae were not dark but more like the fore- and mid-legs; sometimes they are almost entirely yellow but the exterior is darker than the interior. Wings hyaline, the veins dark brown including the stigma; base of the costa pale. Silver appressed pubescence on the clypeus and lower frons, especially laterally. Morphology - mandibles with one inner subapical tooth; frons punctate over a microsculpture; vertex less closely punctate also over a microsculpture; mesonotum and scutellum with fine spaced punctures, the spaces between much greater than the diameter of the punctures, without microsculpture, shining; propodeum coarsely sculptured and shining; the dorsal surface anteriorly with longitudinal striae, posteriorly rugose; laterally striate; metanotum smooth and shining, sometimes striate; mesopleurae rugose above, shining and finely punctate below; mesosternum finely punctate; metatarsi 1 strongly curved; metatarsi 2 slightly curved. Length: 3-4 mm.

Females: Colour - black, except mandibles yellow, ferruginous apically; apex of Ant 1 dark ferruginous, sometimes black; pronotal tubercles yellow; tegulae brown / decoloured; T6 dark ferruginous apically; legs 1 yellow to light ferruginous from apex of femora, tibiae darker, almost ferruginous after yellow base; legs 2 as Legs 1 but tibiae clearly ferruginous after base; legs 3 darker still, tibiae dark ferruginous, tarsi ferruginous. Slight silver appressed pubescence on clypeus and lower part of frons, especially laterally; mandibles and clypeus with a few longer darker hairs; temples and vertex often with short silver erect not very noticeable hairs; abdomen 
with slight silver pruinescence laterally. Wings hyaline, veins black, those of the hindwing light brown basally. Morphology - clypeus impunctate, glabrous and the apical lobe with mesal emargination; Ant $3+$ Ant $4=$ Ant 5; frons densely and finely punctate over microsculpture; vertex finely punctate, but spaces much greater then diameter of punctures, over microsculpture; mesonotum and scutellum finely punctate with no microsculpture; metanotum anteriorly impunctate, posteriorly with a row of large punctures; propodeum coarsely sculptured, the anterior part of the dorsal surface with coarse longitudinal striae, laterally diagonally striate, posteriorly transveresly striate from the mesal impression; metapleurae glabrous; mesopleurae rugose above, finely punctate below; mesosternum with fine, spaced punctures; pygidial area punctate over microreticulation. Length: 4.5-5.5 mm.

Range: Spain, Algeria, Tunisia, Libya (Tripolitania, Cyrenaica), Egypt, Israel, Turkey, Sudan. Oman

Distribution: Abu Rawash, Abydos, Aswan, Cairo, Dahshur. Edfu, Fayyid, Fayyum (Hawara Maktaa, Karanis), Gebel el Asfar, Giza (Pyramids), Helwan, Kerdasa, Kom Awshim, Kom Ombo, Luxor, Maadi, Saqqara, Wadi el Natrun, $35 \mathrm{~km}$ E of Wadi el Natrun

Flight: males (1-6, 8-11), females (1-5, 7-11)

Collections: CGR, WJP

\section{Diodontus longicornis de Beaumont, 1960}

Diodontus longicornis de Beaumont, 1960a: 248-249, $\curvearrowright,+$; holotype $q$ in coll. de Beaumont in MZL; loc. typ. Algeria - Biskra.

Egyptian synonyms:

Range: Algeria, Libya (Cyrenaica), Egypt

Distribution: Cairo, Dekhela, Kingi Mariut

Flight: males (4), females (3) (per de Beaumont)

Collections: evidence that it occurs in Egypt is not known

\section{Diodontus oraniensis (Lepeletier, 1845) ssp. oraniensis (s.s.)}

Diodontus oraniensis Lepeletier, 1845: 97; lectotype $\delta$ from Algeria (IMZUT) designated by de Beaumont, 1951: 316

Diodontus moricei Kohl, 1901a: 125-127, ô, o; lectotype (NHMW: designated by de Beaumont, 1958d); loc. typ. Egypt-Helwan. The synonymy of moricei with oraniensis was established by de Beaumont, 1956a.

Diodontus punicus Ed. André, 1888: 219. [Kohl, 1901a.]

Egyptian synonyms:

Diodontus punicus

Diodontus Moricei

Diodontus oraniensis

Honoré, 1942.

Honoré, 1942.

de Beaumont, 1952, 1956a:211 \& 1958d:67;

Diondontus moricei (sic)

Pulawski, 1964: 143

Diagnosis: (15 males and 6 females examined.)

Males: Colour - black, except the following: mandibles yellow ferruginous at apex; palps yellow; sometimes a yellow spot at apex of Ant 1; pronotal tubercles pale yellow / ivory; tegulae ivory anteriorly, decoloured posteriorly; T7 dark ferruginous, as are sometimes T6 and S6 \& 7; legs yellow from apex of femora; dark line on posterior of tibiae; tarsi darker apically. White decumbent hairs and some silver appressed pubescence on clypeus and lower frons; white erect hairs on temples and femora 1 beneath. Wings hyaline, veins black, except basally brown and hindwing costa yellow-brown. Morphology - clypeus with mesal lobe slightly emarginate, much less so than in friessei, punctate; frons and vertex matt, with even microsculpture; mesonotum and scutellum with fine punctures over microsculpture, matt; propodeum coarsely rugose anteriorly and laterally striate; metapleurae smooth and shining; mesopleurae coarsely sculptured above, posteriorly less so, rugose, below transversely striate; legs 1 with tibiae straight. Length 3.25-4 mm.

Females: Colour - black, except the following areas: mandibles dull yellow ferruginous apically; pronotal tubercles pale yellow; tegulae brown / decoloured with anterior ivory spot; T6 ferruginous; legs dull yellow from apex of femora, but tibiae with brown area varying from small on posterior surface to covering the whole tibiae except its base. Morphology - mesal lobe of clypeus emarginate; clypeus and lower frons (between antennal sockets) smooth and shining; 
frons above antennal sockets and vertex (except between posterior ocelli, smooth and shining) with fine widely spaced punctures over microsculpture; mesonotum and scutellum with fine widely spaced punctures over microsculpture; propodeum coarsely sculptured, shining, rugose, a few longitudinal ridges anteriorly, striae posteriorly; metapleurae rugose above, with transverse striae posteriorly; mesopleurae below and mesosternum with fine widely spaced punctures over microsculpture; pygidial area punctate over microsculpture. Length 3.5-5 mm.

Range: Morocco, Algeria, Libya (Tripolitania, Fezzan, Cyrenaica), Egypt, Palestine

Distribution: Fayyum (Hawarah Maktaa), Gebel el Asfar, Helwan, Kerdasa, Luxor, Maadi, Wadi el Natrun, $35 \mathrm{~km}$ E of Wadi el Natrun

Flight: males (1-4), females (1, 3-4)

Collections: CGR, WJP

Protostigmus Turner, 1918

Protostigmus sinaiticus (Mochi, 1940)

Ammoplanopterus sinaiticus Mochi, 1940: 27-30, đ̊; holotype $\overbrace{}^{\lambda}$ in coll. Mochi (MRSN); loc. typ. Egypt - Sinai, Wadi Umm Mitla.

Egyptian synonyms:

Ammoplanopterus sinaiticus $\quad$ Mochi, 1940; Honoré, 1942.

Protostigmus sinaiticus Bohart \& Menke, 1976.

Range: E. mediterranean region

Distribution: Sinai

Spilomena Shuckard, 1838

Spilomena sp.

Egyptian synonyms:

First records of the genus from Egypt

Distribution: Ikingi Mariut. Sinai - Wadi Mitla

Flight: (4)

Collections: AM

Psenini

Mimesa Shuckard, 1837

Mimesa aegyptiaca Radoszkowski, 1876

Mimesa aegyptiaca Radoszkowski, 1876: 1876: 131, Ô, o+; loc.typ. 'Egypt' (ZMJU)

Egyptian synonyms:

Mimesa aegyptiaca Bohart \& Menke, 1976.

Range: Egypt, Oman

Mimesa sublaevis (de Beaumont, 1954)

Psen (Mimesa) sublaevis de Beaumont, 1954c: 3-4, ô; loc. typ. Gran Canaria (MZHF)

Egyptian synonyms:

Psen (Mimesa) sublaevis Pulawski, 1964; Osborn \& Krombein, 1969. The record of Osborne \& Krombein, 1969, is from Gebel 'Uweinat, but from the Sudanese part.

Range: Canary Is., Algeria, Chad (Tibesti), Libya (Fezzan), Egypt, Sudan (Gebel 'Uweinat)

Distribution: Kom Ombo

Flight: females (2)

Collections: WJP 


\title{
EREMIASPHECIINAE
}

\author{
Eremiaspheciini
}

Eremiasphecium Kohl, 1897

Eremiasphecium schmiedeknechtii Kohl, 1897

Eremiasphecium Schmiedeknechtii Kohl, 1897: 69, §̂, o+; type in NHMW; loc. typ. Egypt - AdelenInseln nr Dahshour. [Pulawski, 1965b.]

Egyptian synonyms:

Eremiasphecium Schmiedeknechti

Eremiasphecium schmiedeknechtii

Honoré, 1942.

de Beaumont, 1949a; Pulawski, 1965b; de Beaumont, 1968a; Bohart \& Menke, 1976;

Range: Canary Is., Egypt, sw USSR Pulawski, 1992b.

Distribution: "Adelen-Inseln" near Dahshur

\section{Laphyragogini}

Laphyragogus Kohl, 1889

\section{Laphyragogus pectinatus de Beaumont, 1959}

Laphyragogus pictus Kohl - Mochi \& Mochi, 1937 (p.p.)

Laphyragogus pectinatus de Beaumont, 1959: 728-729, §̊, , ; holotype $\widehat{\sigma}$ in coll. de Beaumont in MZL; loc. typ. Israel - Revivim.

Egyptian synonyms:

Laphyragogus pectinatus

de Beaumont, 1959; de Beaumont \& Bytinski-

Diagnosis:

Salz, 1973 .

Female: Colour - head black, except the following areas: mandibles pale yellow basally, light ferruginous mesally and black apically; clypeus entirely yellow ferruginous in one specimen, black basally in the other; Ant 1 light ferruginous anteriorly, posteriorly black basally and almost white apically; Ant 2-3 light ferruginous anteriorly, black posteriorly; Ant 4-12 black. Thorax black, except the following areas: posterior margin of pronotum with very narrow almost white band; pronotal tubercles light ferruginous; tegulae yellow; scutellum posteriorly with narrow ferruginous line in the middle; metanotum ivory; propodeum with posterolateral angles of the dorsal area dull ferruginous. Abdomen: T1-5 basally ferruginous (T3-4 darker), mesally a yellow band, wider laterally, the apical margin decoloured; in one example the middle of the yellow bands were grey; T6 ferruginous; S1-6 ferruginous, S3 \& 4 darker than the others. Legs 1 trochanters light ferruginous, femora ferruginous above and the remainder yellow; Legs 2 as legs 1 but the coxae apically light ferruginous. Silver appressed pubescence on clypeus laterally only, and frons along the posterolateral margin of the metanotum. Long white hairs on: underside of the mandibles; vertex, a transverse strip behind the posterior ocelli quite dense but shorter; temples; occiput; propodeum; mesopleurae; abdomen with hairs laterally on the margins of the tergites and along the apical margins of the sternites. Morphology - mandibles, curved, pointed, with an externoventral notch; mouthparts very wide, protruding beyond the mandibles; clypeus apically evenly curved, with scattered punctures; frons densely punctate, with a longitudinal impression; vertex densely punctate; temples impunctate; eyes curved inwards above from mid-point; ocelli in very shallow triangle; POL > OOL; Ant1 swollen apically along the inner margin; Ant 3 slightly curved, length subequal to Ant $4+5$; pronotum in lateral view much below the level of the mesonotum, impunctate but with microsculpture; mesonotum densely punctate along anterior margin, elsewhere only scattered punctures, shining; scutellum and metanotum scattered punctures, shining; propodeum densely punctate on dorsal area, laterally chagrined below the carina marking the edge of the dorsal area; metapleurae with depressed channel to receive femora 3; mesopleurae above with microsculpture, as on the anterior surface, below matt with scattered punctures; mesosternum shining and almost 
impunctate; S6 slightly emarginate laterally and rounded at apex, rugose. Legs 1 - femora with long hairs along both upper and lower margins, smooth and shining, tibiae similar to femora but with stout modified apical spur, tarsi highly asymetrical, the metatarsi with an apical lobe equal in length to the remainder of the tarsomere, bearing 14 external comb hairs and the inside of the process with many more long hairs, tarsomeres 2-4 also apically produced with long hairs, tarsomere 5 very long. Legs 2 - femora and tibiae smooth and shining, the tibiae with many hairs and spines, apically with one spur, tarsi with long stiff hairs. Legs 3 similar to legs 2 but tibiae with 2 apical spurs. Pulvilli absent.

Range: n. Africa, Egypt, Israel

Distribution: Wadi Digla

Flight: males (5), females (5)

Collections: CGR

\section{Laphyragogus pictus Kohl, 1889}

Laphyragogus pictus Kohl, 1889: 190, figs., +; loc. typ. Egypt (ZMHU). [Mochi \& Mochi, 1937; de Beaumont, 1959.]

Egyptian synonyms:

Laphyragogus pictus

Morice, 1911; Mochi \& Mochi, 1937; Honoré, 1942; de Beaumont, 1959; de Beaumont \&

Range: n. Africa, Israel Bytinski-Salz, 1973.

\section{CRABRONINAE}

Larrini

Gastrosericus Spinola, 1839

\section{Gastrosericus drewseni Dahlbom, 1845}

Gasterosericus (sic) Drewseni Dahlbom, 1845: 467, + , incorrect capitalisation; lectotype $\bigcirc$ in NRS coll Hedenborg, designated by de Beaumont, 1960a: 245; loc. typ. Egypt, no specific locality [Pulawski, 1995]

Egyptian synonyms:

Gastrosericus drewseni de Beaumont, 1960a: 245 \& 1966; de Beaumont

Range: Libya, Egypt, Israel \& Bytinski-Salz, 1973; Pulawski, 1995.

Distribution: Mersa Matruh, Wadi Digla

Flight: males (8)

Collections: CGR

\section{Gastrosericus funereus Gussakovskij, 1931}

Gastrosericus funereus Gussakovskij, 1931: 455 oे; holotype $\delta$ in ZIL; loc. typ Turkmenistan, Anau near Askhabad. [Pulawski, 1995]

Gastrosericus apostoli de Beaumont, 1967b: 352-353, ô, o; type in JG; loc. typ. Turkey Mersin (Tarsus). Pulawski, 1982: 263 synonymised G. apostoli with G. funereus.

Egyptian synonyms:

Gastrosericus apostoli Bohart \& Menke, 1976.

Gastrosericus funereus Pulawski, 1995

Range: Morocco, Egypt, Israel, Turkey, Oman, Arabian peninsula, sw USSR, Pakistan

Distribution: $18-25 \mathrm{~km} \mathrm{~W}$ of Suez

\section{Gastrosericus guigliae de Beaumont, 1956}

Gastrosericus guigliae de Beaumont, 1956a: 203-204, + ; holotype + in coll. BMNH; loc. typ. Libya - Tripolitania (Garian).

Egyptian synonyms:

Gastrosericus guigliae Bohart \& Menke, 1976; Pulawski, 1995 
Range: Libya (Tripolitania), Egypt

Distribution: Kom Awshim, Wadi el Tih

Flight: males (5), females (6)

Collections: WJP

Gastrosericus marginalis Gussakovskij, 1931

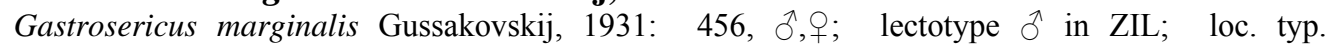
Turkmenistan, Krasonovdsk, designated by Pulawski, 1995: 88. [Pulawski, 1995]

Egyptian synonyms:

Gastrosericus marginalis

Pulawski, 1964; Bohart \& Menke, 1976;

Range: sw USSR, Egypt Pulawski, 1995.

Distribution: Kom Awshim, Wadi Digla

Flight: males $(5,10)$, females (4-6)

Collections: CGR, WJP

Gastrosericus moricei E. Saunders, 1910

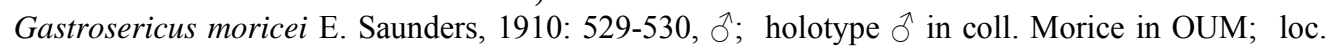
typ. Algeria - Biskra.

Egyptian synonyms:

Gastrosericus Moricei Honoré, 1942.

Gastrosericus moricei Pulawski, 1964, 1995.

Range: Senegal, Libya (Tripolitania), Egypt, Israel, Arabian peninsula, Oman, Somalia, sw USSR, Sri Lanka

Distribution: Abu Rawash, Dahshur, Dakhla Oasis (Al Qasr), Giza, Giza (Pyramids), Kerdasa, Kom Awshim, Maadi. Wadi el Natrun, $35 \mathrm{~km}$ E of Wadi el Natrun. Sinai - Hamamat Faraoun

Flight: males (4-5, 7-8), females (4-7)

Collections: CGR, WJP

\section{Gastrosericus pnepheros Pulawski, 1995}

Gastrosericus pnepheros Pulawski, 1995: 101-104, figs. 82, 86, 87, §, , ; holotype đ in CAS; loc. typ. Egypt, Fayyum, Karanis.

Egyptian synonyms:

Gastrosericus guigliae Pulawski, 1964 (with descr of ?)

Gastrosericus pnepheros Pulawski, 1995

Range: Egypt

Distribution: Kharga Oasis (Dush)

Flight: males $(6-7,10)$

Collections: CGR

\section{Gastrosericus thoth Pulawski, 1995}

Gastrosericus thoth Pulawski, 1995: 137-139, figs. 123 \& 124, §,ף; holotype $q$ in NHMW; loc. typ. Egypt, Wadi Hof

Egyptian synonyms:

Gastrosericus thoth Pulawski, 1995

Range: Egypt

Distribution: Wadi Hof

\section{Gastrosericus waltlii Spinola, 1839}

Gastrosericus Waltlii Spinola, 1839: 481-482, $\hat{\sigma}$, incorrect capitalisation; lectotype $\widehat{\delta}$ in coll. IMZUT, designated by de Beaumont, 1952c: 49; loc. typ. Egypt.

Egyptian synonyms:

Gastrosericus Waltlii

Gastrosericus waltlii

Honoré, 1942.

de Beaumont, 1950c; Pulawski, 1964 \& 1965b; Osborn \& Krombein, 1969. The record of Osborne \& Krombein, 1969, is from Gebel

Gastrosericus waltli 'Uweinat, but from the Sudanese part. de Beaumont \& Bytinski-Salz, 1973. 
Range: Algeria, Chad (Tibesti), Sudan (Gebel 'Uweinat), Libya (Tripolitania), Egypt, Cyprus , Rhodes, Turkey, Oman, Mongolia

Distribution: 25km S of Ain Sokhna, Baharia Oasis, Dakhla Oasis (Tineida), Fayyum (Hawara, Karanis), Giza (Pyramids), Helwan, Kerdasa, Kom Awshim, Wadi Digla, Wadi Hoff. Sinai $10 \mathrm{~km}$ E of el Arish, St. Catharine's

Flight: males (4-10), females (4-6, 8-9)

Collections: CGR, WJP

\section{Holotachysphex de Beaumont, 1940}

\section{Holotachysphex holognathus (Morice, 1897)}

Tachysphex (?) integer Morice, 1897a: 308-309, pl. 6 figs. 13 \& 14, §,, o; lectotype $\widehat{\sigma}$ in OUM; loc. typ. Egypt - Zeitun nr Cairo; designated by Pulawski, 1992a; nec Tachysphex integer Kohl, 1892 = Parapiagetia genicularis (F. Morawitz, 1890).

Tachysphex (?) holognathus Morice, 1897b: 434, nom. nov. for Tachysphex integer Morice, nec Kohl, 1892. [Pulawski, 1975 \& 1992a.]

Egyptian synonyms:

Tachysphex (?) integer

Tachysphex (?) holognathus

Tachysphex holognathus

Tachysphex (Holotachysphex) holognathus

Holotachysphex holognathus

Range: Egypt, Crete, w India, Sri Lanka

Distribution: Gebel el Asfar, Kom Awshim

Flight: males (6), females (8)

Collections: CGR
Morice, 1897a.

Morice, 1897b.

de Beaumont, 1940; Honoré, 1942.

de Beaumont, 1947, 1961b.

de Beaumont, 1961b; de Beaumont \& BytinskiSalz, 1973; Pulawski, 1975; Bohart \& Menke, 1976; Pulawski, 1992a.

\section{Larra Fabricius, 1793 sg. Larra (s.s.)}

\section{Larra anathema (Rossi, 1790)}

Sphex anathema, Rossi, 1790: 65, o; loc. typ. Italy - Tuscany (type destroyed). [Guiglia, 1939.]

Egyptian synonyms:

Larra anathema L. (sic)

Larra anathema

Storey, 1916.

Honoré, 1942; de Beaumont, 1950c.

Range: L. anathema anathema (Rossi) - s. Europe, n. Africa, Iraq

L. anathema melanaria Kohl - Italy, Morocco

L. anathema nudiventris A.Costa - Tunisia

Presumably, the Egyptian specimens will be of the nominotypical subspecies

Distribution: Fayyum (Karanis), Wadi el Natrun

Flight: females (5)

Collections: AM, CGR

\section{Liris Fabricius, 1804}

aurulentus species group

\section{Liris braueri Kohl, 1884}

Liris Braueri Kohl, 1884: 356, O̊, o; type in NHMW; loc. typ. Egypt - Sinai (Tor). [de Beaumont, 1961d.]

Egyptian synonyms:

Liris Braueri

Honoré, 1942. 
Liris braueri

Range: Egypt, Jordan, S.Yemen, Oman, Iran Distribution: Gebel Elba, Sinai - Tor

Flight: males (1) de Beaumont, 1961d: 223; de Beaumont \& Bytinski-Salz, 1973; Bohart \& Menke, 1976.

\section{Liris haemorrhoidalis (Fabricius, 1804)}

Liris hamorrhoidalis Fabricius, 1804: 198. holotype $q$ in ZMK; loc.typ. Guinea [Arnold, 1923] Lyrops Savignyi, Spinola, 1839: 476-477, 9 ; type in coll. IMZUT; loc. typ. Egypt. de Beaumont, 1961d.

Tachytes illudens Lepeletier, 1845: 440, 249, +; type whereabouts unknown; loc. typ. Egypt. [de Beaumont, 1961d.]

Egyptian synonyms:

Liris haemorroidalis

Storey, 1916; Honoré, 1942; de Beaumont, 1950c \& 1961d: 222, Sayed et al, 1964; de Beaumont \& Bytinski-Salz, 1973.

Range: Spain, Italy (Sicily); all Africa including Guinea, Canary Is., Spanish Sahara, Morocco, Algeria, Tunisia, Libya (Tripolitania, Fezzan), Chad (Tibesti), Egypt; Palestine, Syria, Turkey, Oman, w. India, Sri Lanka

Distribution: Fayyum (Karanis), Helwan, Kom Awshim, Saqqara

Flight: males (2-3, 5-6, 8-12), females (9)

Collections: CGR

\section{memnonius species group}

\section{Liris memnonius (F. Smith, 1856) ssp. memnonius (s.s.)}

Larrada Memnonia F. Smith, 1856: 281, +; holotype in BMNH; loc. typ. Egypt. [de Beaumont, 1961d.]

Tachytes funebris Radoszkowski, 1876: 135, + ; type whereabouts unknown; loc. typ. Egypt. [de Beaumont, 1961d.]

Egyptian synonyms:

Notogonia memnonia

Larra memnonia (sic)

Storey, 1916.

Arnold, 1923. In Arnold's defence, he stated he had never seen this species "in nature" and that it was probably a Notogonidea.

Notogonidea memnonia Honoré, 1942; Sayed et al, 1964.

Leptolarra sp. aff. memnonia

Liris memnonia

de Beaumont, 1940a.

de Beaumont, 1961d: 226; Pulawski, 1964: 82;

Liris memmonia (lapsus)

Bohart \& Menke, 1976.

de Beaumont, 1950c.

Range: Tropical Africa, Morocco, Algeria, Libya (Tripolitania, Fezzan), Egypt, Palestine, Oman

Distribution: Aswan, Cairo (environs), Kerdasa

Flight: females $(2,4)$

Collections: CGR, WJP

\section{Liris solstitialis (F. Smith, 1856) ssp anubis de Beaumont, 1970}

Notogonidea solstitialis Smith, 1856: 283, + ; syntypes from South Africa (BMNH) [Arnold, 1923.] Liris solstitialis tibialis de Beaumont, 1961d: 228-229, $\curvearrowright, \propto$; holotype $q$ in coll. de Beaumont in MZL; loc. typ. Egypt - Helwan. 5.ix.1933

Liris solstitialis anubis de Beaumont, 1970: 17, nom. nov. for Liris solstitialis tibialis de Beaumont, 1961d, nec Arnold, 1923

Egyptian synonyms: Leptolarra sp. aff. solstitialis Notogonidea affinis solstitialis Liris solstitialis tibialis

de Beaumont, 1940a.

Honoré, 1942.

Liris solstitialis anubis de Beaumont, 1970; de Beaumont \& BytinskiSalz, 1973.

Range: Egypt, Sudan 
Distribution: Abu Rawash, Gebel el Asfar, Giza, Helwan, Kerdasa, Maadi, Tell el Kebir, Wadi el Natrun

Flight: males $(2-3,9,12)$, females (9-10)

Collections: CGR

\section{Liris subfasciatus (Walker, 1871)}

Larrada subfasciata Walker, 1871: 21, ; ; holotype in BMNH; loc. typ. Egypt. [de Beaumont, 1961d.]

Egyptian synonyms:

Leptolarra memnonia Smith, 1856 de Beaumont, 1940a. This misidentification was

Liris subfasciata

recognized in de Beaumont, 1961d.

de Beaumont, 1961d.

Range: Zaire, Ivory Coast, Morocco, Mauritania, Algeria, Libya (Tripolitania, Fezzan), Egypt Sudan, Oman

Distribution: Abu Sir, Cairo (environs), Gebel el Asfar, Kom Awshim, el Minia, Siwa Oasis, Tell el Kebir, 10th Ramadan City, Wadi el Natrun

Flight: males $(1-3,7,9,11)$, females $(1-2,4,9-10)$

Collections: CGR

atratus species group

\section{Liris atratus (Spinola, 1805)}

Larra atrata Spinola, 1805: 12; holotype in IMZUT; loc. typ. Italy - Genoa. [de Beaumont, 1961d.]

Tachytes nigrita Lepeletier, 1845: 241, ふ̂,,+ ; holotype in MNHN; loc. typ. Algeria - Oran. [de Beaumont, 1961d.]

Notogonia pharaonum Kohl, 1906b: 220, ô; holotype in NHMW, loc. typ. Egypt. [de Beaumont, 1961d.]

Egyptian synonyms:

Notogonia nigrita Storey, 1916.

Leptolarra nigrita de Beaumont, 1940a.

Leptolarra pharaonum de Beaumont, 1940a.

Notogonidea nigrita Honoré, 1942; Sayed et al, 1964.

Notogonidea pharaonum Honoré, 1942.

Liris nigrita

Liris atrata de Beaumont, 1961d:231 \& 1966.

Range: France, Iberian peninsula, Canary Is., Cape Verde Is., Mauritania, Spanish Sahara, Algeria, Chad (Tibesti), Libya (Tripolitania, Fezzan, Cyrenaica, Kufra), Egypt, Palestine,Syria, Turkey, Cyprus, Iraq, Iran

Distribution: Helwan, Kom Awshim, Wadi Digla, Wadi el Natrun

Flight: males (1-4, 9)

Collections: CGR

\section{Liris cleopatra de Beaumont, 1961}

Liris cleopatra de Beaumont, 1961d: 231-233, ڤ̂, , ; type in coll. WJP; loc. typ. Egypt - Cairo (Giza) 25.xii.1957.

Egyptian synonyms:

Liris cleopatra

Range: Sudan, Egypt, Israel

Distribution: Giza, km55 Cairo-Suez road, Luxor, Tell el Kebir

Flight: males (2-3, 7, 9, 11-12), females (12)

Collections: CGR, WJP 
nigricans species group

\section{Liris nigricans (Walker, 1871) ssp. nigricans (s.s.)}

Larrada nigricans Walker, 1871: 21, ; ; type in BMNH; loc. typ. Cairo, Egypt \& Hor Tamanib, Sudan. [de Beaumont, 1961d.]

Notogonia argyropyga Costa, 1875: 16, + , (nec $\left.{ }^{\Uparrow}\right)$; type in MZUN; loc. typ. Egypt. [de Beaumont, 1961d.]

Notogonia sculpturata Kohl, 1892: 221, ô; type ? in NHMW; loc. typ. Egypt. [de Beaumont, 1961d.] Turner, 1917: 319, synonymised this species with nigricans; de Beaumont 1961d agreed. [Arnold, 1923]

Notogonia palumbula Kohl, 1894: 304, ô; type in TMB; loc. typ. Cameroons. [de Beaumont, 1961d.] Richards, 1928, believed this to be a synonym of nigricans and de Beaumont, 1961d, followed this opinion.

Egyptian synonyms:

Larrada nigricans

Innes, 1911.

Leptolarra nigricans

de Beaumont, 1940a.

Notogonidea nigricans

Honoré, 1942.

Notogonidea argyropyga

Honoré, 1942.

Notogonidea palumbula

Honoré, 1942.

Liris nigricans

de Beaumont, 1950c \& 1961d: 234.

Range: All Africa, Cape Verde Is., Canary Is., Spanish Sahara, Algeria, Libya (Tripolitania, Fezzan, Cyrenaica), Chad (Tibesti), Egypt, Palestine, Syria, Cyprus, Iraq, Oman, Seychelles

Distribution: Fayyum (Hawara Maktaa), Gebel el Asfar, Helwan, Kharga Oasis (Dush), Kom Awshim, el Minia, Tell el Kebir, $35 \mathrm{~km}$ E of Wadi el Natrun

Flight: males $(1,4,7,10)$, females $(2-4,7-10)$

Collections: CGR

\section{Liris festinans (F.Smith, 1858) ssp. praetermissus (Richards, 1928)}

Larrada festinans F.Smith 1858: 17, $\hat{\partial}$,, ; types from Celebes (=Sulawesi), in BMNH Notogonidea praetermissa Richards, 1928: 361, $\widehat{O}, \mathrm{O}$; holotype $\widehat{O}$ from France (BMNH), placed as subgenus of festinans by Schmidt \& Bitsch in Bitsch et al 2001: 203

Egyptian synonyms: Notogonia n. sp., nr. argyropyga Costa, 1875 Storey, 1916, may be this species.

Notogonidea sculpturata Kohl, $1892 \quad$ Honoré, 1942. Honoré believed sculpturata to be a synonym of praetermissa Richards; as he did not otherwise record nigricans, perhaps he misused the name sculpturata for that species.

Leptolarra praetermissa de Beaumont, 1940a.

Liris praetermissa de Beaumont, 1961d: 236.

Range: Iberian peninsula, France, Italy, Greece (Corfu), Bulgaria, Morocco, Algeria, Tunisia, Egypt, Sudan, Syria, Turkey, Rhodes, Cyprus, Oman, Iran

Distribution: Kom Awshim, el Minia, Tell el Kebir

Flight: males $(1,8-9,12)$, females $(1,7,9)$

Collections: CGR

niger species group

\section{Liris agilis (F. Smith, 1856)}

Larrada agilis F. Smith, 1856: 284, + ; holotype + in coll. BMNH; loc. typ. Gambia. [de Beaumont, 1961d.]

Liris cooperi de Beaumont, 1950c: 16, Ô,, ; holotype $\odot$ in BMNH; loc. typ. Egypt - Siwa Oasis. De Beaumont, 1961d, synonymized his cooperi with agilis.

Egyptian synonyms:

Leptolarra agilis de Beaumont, 1940a.

Liris cooperi de Beaumont, 1950c.

Liris agilis de Beaumont, 1961d: 242.

Range: Canary Is., Cape Verde Is., Gambia, Mauritania, Morocco, Algeria, Libya (Tripolitania, Cyrenaica), Egypt, Jordan, Sudan, Oman 
Distribution: Aswan, Cairo (environs), Fayyum (28km W of Shakshuk), Gebel el Asfar, Helwan, Kom Ombo, Sidi Abdel Rahman, Siwa Oasis

Flight: males (8-10), females $(5,10)$

Collections: CGR

\section{Liris niger (Fabricius, 1775) ssp. niger (s.s.)}

Notogonidea pompiliformis Panzer, 1806-1809: 106 nec Panzer, 1805 [de Beaumont, 1961d.] Tachytes nigra Vander Linden, 1829: 23; type ?; loc. typ. Italy or Spain [de Beaumont, 1961d.]

Egyptian synonyms:

Notogonia pompiliformis Storey, 1916.

Notogonidea pompiliformis $\quad$ Honoré, 1942; Sayed et al, 1964.

Liris nigra de Beaumont, 1961d: 230.

Range: Spain, France, Italy, Czechoslovakia, Hungary, the Balkans, Rhodes, Crete, Cyprus, Turkey, Syria, Israel, Egypt, Libya (Tripolitania, Cyrenaica), Algeria, Iraq, sw USSR, Afghanistan, India

Distribution: Cairo, Fayyum (28km W of Shakshuk), Sidi Abdel Rahman

Flight: males (8), females (10)

Collections: CGR

\section{Liris opalipennis (Kohl, 1898) ssp. opalipennis (s.s.)}

(Liris) opalipennis Kohl, 1898: 1898: 98, + ; syntype + from Oran \& Biskra, Algeria (type location not stated)

Egyptian synonyms:

Notogonidea opalipennis Honoré, 1942.

Liris opalipennis

de Beaumont, 1950c \& 1961d.

Range: Algeria, Tunisia, Egypt

Distribution: Cairo (environs), Siwa Oasis

miscophoides species group

\section{Liris miscophoides Arnold ssp. aegyptiacus de Beaumont, 1961}

Notogonidea miscophoides Arnold, 1923: 248-249, figs., $q$; holotype $q$ in NMSR; loc. typ. S. Rhodesia - Bulawayo.

Liris miscophoides aegyptiaca de Beaumont, 1961d: 244-245; đ, , ; type in coll. WJP; loc. typ. Egypt - Cairo (Giza). 25.xii.1957

Egyptian synonyms:

Leptolarra ? miscophoides Notogonidea ? miscophoides

Liris miscophoides aegyptiaca

Range: Egypt, Oman

Distribution: Cairo (environs), Giza

Flight: males (12), females $(9,12)$ de Beaumont, 1940a.

Honoré, 1942.

de Beaumont, 1961d; de Beaumont \& BytinskiSalz, 1973; Bohart \& Menke, 1976.

\section{ciliatus species group}

\section{Liris pictipennis (Maidl, 1924)}

(Liris) pictipennis Maidl, 1924: 238, đ̂,, ; syntypes from El Obeid, Sudan (NHMW)

Egyptian synonyms: first record from Egypt.

Range: Sudan, Egypt

Distribution: Tell el Kebir

Flight: males (7)

Collections: CGR 
Parapiagetia Kohl, 1896

odontostoma species group

Parapiagetia genicularis (F. Morawitz, 1890)

Tachysphex genicularis F. Morawitz, 1890: 592, ; holotype $\odot$ in ZIL; loc. typ.Turkemenistan Pereval between Djebel and Kazandjik. [Pulawski, 1975 \& 1977.]

Egyptian synonyms:

Parapigetia genicularis Bohart \& Menke, 1976; Pulawski, 1977.

Range: Egypt, Israel, Turkey, USSR (Georgian SSR, Armenian SSR, Uzbek SSR, Turkmen SSR, Tadjik SSR), Pakistan

Distribution: Wadi Hoff

Collections: USNM

\section{Parapiagetia mongolica (F. Morawitz, 1889)}

Piagetia mongolica F. Morawitz, 1889: 130, ô,, ; lectotype + in ZIL (designated by Pulawski, 1977); loc. typ. China - Inner Mongolia, Zagan Buryuk on Edsin-gol River. [Pulawski, 1977.] Parapiagetia zorah de Beaumont, 1955a: 195, $\widehat{0}$,,+ ; holotype ${ }_{+}$in coll. MZL; loc. typ. Egypt Fayum. [Pulawski, 1977.] Pulawski, 1977, synonymised zorah with mongolica.

Egyptian synonyms:

Parapiagetia zorah Parapigetia mongolica

Pulawski, 1961.

Pulawski, 1977.

Range: Morocco, Algeria, Libya (Fezzan, Tripolitania), Chad (Tibesti), Egypt, USSR (Kazakh SSR, Turkmen SSR, Tadjik SSR), China (Inner Mongolia)

Distribution: Abu Zabal, Baharia Oasis, Dahshur, Fayyum, Kharga Oasis (El Kharga), Kom Awshim, Wadi el Natrun (Bir Hooker)

Flight: males (3-5), females $(4-6,9,11)$

Collections: CGR, WJP, USNM

\section{Parapiagetia odontostoma (Kohl, 1884)}

Piagetia odontostoma Kohl, 1884: 359, $\odot$; lectotype $\odot$ in NHMW (designated by Pulawski, 1977) ; loc. typ. Egypt - Sinai, Tor. [Pulawski, 1977.]

Egyptian synonyms:

Parapiagetia odontostoma Honoré, 1942; Pulawski, 1961; Bohart \& Menke, 1976; Pulawski, 1977.

Range: Spanish Sahara (?), Libya (Tripolitania, Cyrenaica), Chad (Tibesti), Egypt, Sinai, Israel, S.Yemen

Distribution: Helwan, Kom Awshim. Sinai: Tor

Flight: males (4), females (9)

Collections: CGR, WJP, USNM

erythropoda species group

\section{Parapiagetia erythropoda (Cameron, 1889)}

Tachytes erythropoda Cameron, 1889: 135, + ; holotype $\odot$ in OUM; loc. typ. India - Uttar Pradesh, Mussooree. [Pulawski, 1975 \& 1977.]

Tachytes denticulata, Morice, 1897a: 305, + ; lectotype $q$ in OUM; loc. typ. Egypt - Zeitoun nr Cairo. Pulawski, 1975, synonymised denticulata with erythropoda.

Egyptian synonyms:

Tachytes denticulata

Parapiagetia denticulata

Parapiagetia erythopoda
Morice, 1897a; Honoré, 1942.

Pulawski, 1961.

Pulawski, 1975; Bohart \& Menke, 1976; Pulawski, 1977.

Range: South African Republic, Namibia, Botswana, Zimbabwe, Ethiopia, Sudan, Chad, Niger, Mali, Senegal, Mauritania, Libya (Tripolitania, Fezzan), Egypt, Pakistan, India, Sri Lanka

Distribution: Kerdasa, Zeitun 
Collections: MZL, NHMW, OUM

\section{Parapiagetia krombeini Pulawski, 1977}

Parapiagetia krombeini Pulawski, 1977: 641-642, + ; holotype $q$ in USNM; loc. typ. Egypt - 15 $\mathrm{km}$ s. of Ismailia.

Egyptian synonyms: Parapiagetia krombeini Pulawski, 1977.

Range: Egypt

Distribution: $15 \mathrm{~km} \mathrm{~S}$ of Ismailia

Flight: females (4)

Collections: USNM

Prosopigastra A. Costa, 1867

globiceps species group

\section{Prosopigastra creon (Nurse, 1903)}

Homogambrus creon Nurse, 1903: 2; đ; lectotype 0 in BMNH; loc. typ. India - Bombay State, Deesa - designated by Pulawski, 1975. [Pulawski, 1975 \& 1979.]

Homogambrus cimicivora Ferton, 1912: 406, $\widehat{\jmath}$,, ; type lost? or MNHN; loc.typ.: Algeria - La Calle. [Ferton wrote two papers, one in Ann. Soc. Ent. France and the other in Bull. Soc. Ent. France, both in 1912. Bohart \& Menke (1976) refer to the "Ann." one as a nomen nudum. In his 1954a paper, de Beaumont gave the page number of the "Bull." paper as 186. Pulawski (1965) quotes the page as 406. In 1979, Pulawski lists in his references "Prosopigastra cimicivora Ferton, 1912a:406" and cites it as "New synonym". He then lists Homogambrus cimicivorus Ferton, 1912b: 186, female, male. Lectotype male: Algeria: La Calle (MNHN, Paris), present designation."

Egyptian synonyms: Prosopigastra creon Pulawski, 1979.

Range: South African Republic, Botswana, Namibia, Zimbabwe, Zambia,Malawi, Tanzania, Nigeria, Morocco, Algeria, Egypt, Cyprus, Israel, Oman, USSR (Armenian, Uzbek, Turkmen, Tadzhik SSR's), Iran, Pakistan, India

Distribution: Wadi Digla

Collections: MS

\section{Prosopigastra globiceps (F. Morawitz, 1889)}

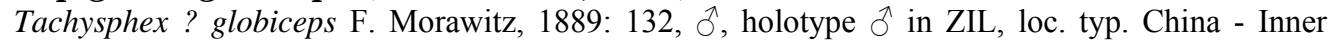
Mongolia, Tsagan Buryuk. [Pulawski, 1979.]

Homogambrus werneri, Maidl, 1924: 235, O, type in NHMW, loc. typ. Sudan - Sennar. [de Beaumont, 1954e; Pulawski, 1979.] Pulawski, 1979, synonymised werneri with globiceps.

Egyptian synonyms:

Prosopigastra (Homogambrus) werneri de Beaumont, 1954e.

Homogambrus werneri

Prosopigastra werneri Prosopigastra globiceps

Honoré, 1942.

Bohart \& Menke, 1976.

Pulawski, 1979.

Range: Mali, Sudan, Egypt, Israel, USSR (Armenian, Kazakh, Turkmen, Tadzhik SSR's), Pakistan, China, Mongolia

Distribution: Gebel el Asfar

Flight: females (7)

Collections: CGR

\section{Prosopigastra major (F. Morawitz, 1890)}

Homogambrus major F. Morawitz, 1890: 591; $\widehat{\jmath}$; holotype $\widehat{\delta}$ in ZIL; loc. typ. Turkmenistan Repetek. [Pulawski, 1979.]

Prosopigastra laevior Morice, 1897a: 309, pl. 6 figs. 16 \& 17; $q$; holotype $q$ in OUM; loc. typ. Egypt - Abbasiyeh nr. Cairo. Pulawski, 1979, synonymised laevior with major. 
Homogambrus sericans Morice, 1897a: 309-310, pl. 6 figs. 18 \& 19; §; holotype $\widehat{\delta}$ in OUM; loc. typ. Egypt - Koubbeh nr. Cairo. De Beaumont, 1954a, synonymised sericans with laevior.

Egyptian synonyms:

Prosopigastra laevior

Morice, 1897a \& 1911; Honoré, 1942; Osborn \& Krombein, 1969; de Beaumont \& Bytinski-Salz, 1973; Bohart \& Menke, 1976. The record of Osborne \& Krombein, 1969, is from Gebel

Homogambrus sericans 'Uweinat, but from the Sudanese part.

Prosopigastra (Homogambrus) laevior Morice, 1897a; Honoré, 1942. Prosopigastra major de Beaumont, 1954e. Pulawski, 1979.

Range: Morocco, Algeria, Egypt, Sudan (Gebel 'Uweinat), Arabia, Israel, USSR (Turkmen, Tadzhik SSR's)

Distribution: Cairo (Abbasieh), Giza, Kafr Farout [?=Farouk], Kerdasa, Koubbeh, Saqqara, Zeitoun

Flight: males (4-5), females (4)

Collections: CGR, NHMW, OUM, USNM, WJP

\section{zalinda species group}

\section{Prosopigastra menelaus (Nurse, 1903)}

Homogambrus menelaus Nurse, 1903: 2; + ; lectotype $\odot$ in BMNH; loc. typ. Pakistan - Pishin $=$ Peshin; lectotype designated by Pulawski, 1979. [Pulawski, 1979.]

Prosopigastra (s.s.) minima de Beaumont, 1956a: 200; đ̊; holotype $\widehat{\jmath}$ in BMNH; loc. typ. Chad - Tibesti, Wadi Wour. Pulawski, 1979, synonymised minima with menelaus.

Egyptian synonyms:

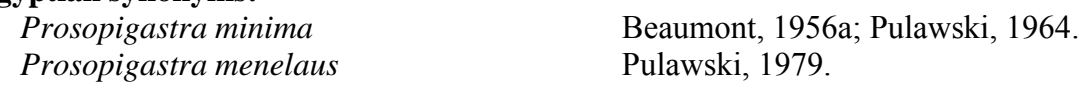

Range: Chad, Egypt, USSR (Kazakh, Turkmen SSR's), Pakistan, w India

Distribution: Abu Rawash, Dahshur, Fayyum (Karanis, Kom el Atl), Giza, Giza (Pyramids), Kerdasa, Kom Awshim, Maadi, Manshiet Radwan (in Giza Prov.), Saqqara, Wadi Digla, Wadi Natrun (Bir Hooker), Wadi Shagra

Flight: males (3-6), females (3-5)

Collections: CGR, MNHN, MS, USNM, WJP, ZIL

\section{Prosopigastra zalinda de Beaumont, 1955}

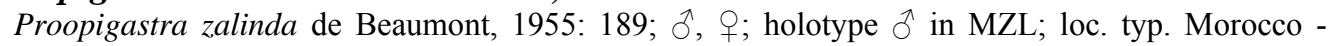
Tiznit, Oued Massa. [Pulawski, 1979.]

Egyptian synonyms:

Prosopigastra zalinda

de Beaumont \& Bytinski-Salz, 1973; Pulawski, 1979.

Range: Morocco, Algeria, Libya (Tripolitania), Egypt, Israel, Spain, Romania, Greece, Bulgaria, Turkey, USSR (Russian, Kazakh SSR's), Mongolia

Distribution: Wadi Digla

Collections: MS

\section{handlirschi species group}

\section{Prosopigastra handlirschi Morice, 1897}

Prosopigastra handlirschi, sp. n., Morice, 1897a: 309, pl. 6 figs. 16 \& 17; ㅇ, holotype in OUM; loc. typ. Egypt - Nakhle nr Cairo.

Egyptian synonyms:

Prosopigastra handlirschi Morice, 1897a; Pulawski, 1979.

Prosopigastra Handlirschi Honoré, 1942.

Prosopigastra (s.s.) handlirschi de Beaumont, 1954e \& 1966.

Range: Spain, Morocco, Spanish Sahara, Niger, Algeria, Tunisia, Libya (Tripolitania, Cyrenaica), Egypt, Eritrea, Israel, Turkey, Oman 
Distribution: Amrye (near Alexandria), Burg el Arab, Cairo, Koubbeh, Maadi, Matariyeh (near Cairo), Nakhle (near Cairo)

Collections: BMNH, MHNG, NHMW, NRS, OUM, SMF, USNM, WJP

punctatissima species group

Prosopigastra fumipennis Gussakovskij, 1952

Prosopigastra fumipennis Gussakovskij, 1952: 252; $\curvearrowright, q$ lectotype $q$ in ZIL; loc. typ. Tadzhikistan - Koy-Pyaz-Tau Mts, nr. Kabadian. [Pulawski, 1979.] Lectotype designated by Pulawski, 1979. Prosopigastra lissipes Pulawski, 1973: 14-15; $\widehat{\partial}$, + ; holotype $\widehat{\sigma}$ in coll. WJP; loc. typ. Egypt Maadi nr. Cairo. Pulawski, 1979, synonymised lissipes with fumipennis.

Egyptian synonyms: Prosopigastra fumipennis

Pulawski, 1979.

Range: Algeria, Egypt, Israel, Turkey, USSR (Uzbek, Tadzhik SSR's)

Distribution: Faywed, Maadi, Wadi Digla, Wadi Hof, Wadi el Tih

Collections: MS, WJP

\section{Prosopigastra insignis E. Saunders, 1910}

Prosopigastra insignis E. Saunders, 1910: 528-529; + ; holotype $q$ in OUM; loc. typ. Algeria Biskra.

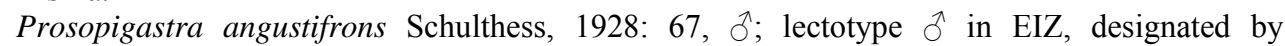
Pulawski, 1979; loc. typ.of lectotype Libya - Cyrenaica (Djarabub). Synonymised with $P$. insignis by de Beaumont, 1954e.

Egyptian synonyms:

Prosopigastra angustifrons $\quad$ Honoré, 1942.

Prosopigastra (s.s.) insignis de Beaumont, 1954e.

Prosopigastra insignis Pulawski, 1964 \& 1979.

Range: Algeria, Libya (Cyrenaica), Egypt, Syria, Iraq, Iran, USSR (Turkmen SSR)

Distribution: Abu Rawash, Baharia Oasis (El Aguz), Dakhla Oasis (Tineida), Giza, Giza (Pyramids), Kom Awshim, Saqqara

Flight: males $(4-5,7)$, females $(5,7)$

Collections: CGR, WJP

\section{Prosopigastra nuda (Nurse, 1903)}

Tachysphex nuda Nurse, 1903: 515; $\bigcirc$; lectotype $q$ in coll. BMNH, designated by Pulawski, 1975; loc. typ. India - Bombay State, Deesa. [Pulawski, 1975 \& 1979.]

Egyptian synonyms: Prosopigastra nuda

Range: Egypt, Oman, India

Distribution: Wadi Digla, Wadi Hof

Flight: males (8-9), females (9)

Collections: CGR, MS, USNM

\section{Prosopigastra punctatissima A, Costa, 1867 ssp. africana de Beaumont, 1955}

Prosopigastra punctatissima A. Costa, 1867: 88; $\partial^{\lambda},+$; lectotype $q$ in MZUN; loc. typ. Italy Puglia, Lecce. Lectotype designated by de Beaumont, 1953b. [Pulawski, 1979.] De Beaumont, 1954a, gives the type in Naples and the loc. typ. as Italy - Terre d'Otrante, without any mention of his designating a lectoype.

Prosopigastra punctatissima africana de Beaumont, 1955: 188; §, §; holotype $\lesssim$ in MZL; loc. typ. Morocco - Goulimine. [Pulawski, 1979.]

Egyptian synonyms: Prosopigastra punctatissima Honoré, 1942; Pulawski, 1979. Prosopigastra punctatissima africana de Beaumont, 1966.

Range: Italy, France, Spain, Portugal, Morocco, Algeria, Libya (Tripolitania, Cyrenaica), Egypt

Distribution: Amrye (=El Amriya near Alexandria)

Collections: NRS 
Tachysphex Kohl, 1883

pompiliformis species group

\section{Tachysphex anubis Pulawski, 1964}

Tachysphex anubis Pulawski, 1964: 98-101, ô, of; holotype in coll. WJP; loc. typ. Egypt - Abu Rawash.

Egyptian synonyms:

Tachysphex anubis Pulawski, 1971; Bohart \& Menke, 1976.

Range: Egypt

Distribution: Abu Rawash, Manshiet Radwan (near Cairo)

Flight: males (3-4), females (3-4)

Collections: WJP

\section{Tachysphex consocius Kohl 1892 ssp. consocius (s.s.)}

Tachysphex consocius Kohl, 1892: 217, ; ; holotype $q$ in coll. NHMW; loc. typ. Azerbaijan Helenendorf (now Khanlar). [Pulawski, 1971.]

Tachysphex Cabrerai Mercet, 1909: 196, Ô, †; holotype in MNMS; loc. typ. Spain - Madrid. [Pulawski, 1971.] Pulawski, 1971, synonymised cabrerai with consocius.

Tachysphex grandii de Beaumont, 1965: 51, đ̂,, ; holotype in MZUB; loc. typ. Italy - Gaibola nr. Bologna. [Pulawski, 1971.] Krombein \& Pulawski, 1994, synonymised grandii with consocius.

Egyptian synonyms:

Tachysphex cabrerai

Tachysphex Cabrerae

de Beaumont, 1940b.

Tachysphex cabrerae

Honoré, 1942.

Beaumont, 1966.

Tachysphex consocius

de Beaumont, 1947 \& 1950c, Pulawski, 1964; de

Tachysphex grandii

Pulawski, 1971; Krombein \& Pulawski, 1994.

Pulawski, 1971; Bohart \& Menke, 1976.

Range: Portugal, Spain. France, Italy, Czechoslovakia, Greece, Hungary, Yugoslavia, Bulgaria, Cyprus, Morocco, Tunisia, Libya,(Tripolitania, Cyrenaica), Egypt, Crete, Turkey, Lebanon, Syria, USSR (Crimea, Sarepta, Azerbaijan, Armenia, Kazakhstan, Uzbekistan, Turkmenistam, Tadjikistan), Oman, Iran, Afghanistan

Distribution: Abu Rawash, Amrieh nr. Alexandria, Aswan, Dahshur, Fayyum, Gebel el Asfar, Giza, Helwan, Kharga Oasis (El Kharga), Kerdasa, Kom Awshim, Maadi, 18-35 km W of Suez, Manshiet Radwan, Sheikh Fadl, Siwa Oasis (Khamissa, Siwa), 35km e of Wadi el Natrun

Flight: males $(4-6,8,10)$, females $(4-6,8)$

Collections: CGR, WJP

\section{Tachysphex erythrophorus Dalla Torre, 1897}

Tachysphex erythrogaster Cameron, 1889: 143,, ; holotype $q$ in coll. Rothney in OUM; loc. typ India - Bombay, Poona. [Pulawski, 1975]

Tachysphex erythrophorus, Dalla Torre, 1897: 679 new name for erythrogaster Cameron, nec Costa, 1882. [Pulawski, 1975]

Tachysphex sp. 18, de Beaumont, 1940: 178 (partim; remainder T. erythrophorus Dalla Torre) [Pulawski, 1971; Krombein \& Pulawski, 1994]

Tachysphex argentatus Gussakovskij, 1952: 242 (ㅇ nec §̋ ) [Pulawski, 1971]

Tachysphex pectoralis sp. n., Pulawski, 1964: 101-105, ô, ᄋ; holotype in coll. WJP; loc. typ. Egypt - Abu Rawash. Pulawski, 1975, synonymised pectoralis with erythrophorus.

Egyptian synonyms:

Tachysphex sp. 18, de Beaumont, 1940: 178 (partim) Pulawski, 1971; Krombein \& Pulawski,

Tachysphex pectoralis 1994.

Tachysphex erythrophorus

Pulawski, 1971; Krombein \& Pulawski, 1994.

Range: Egypt, USSR (Turkmenistan, Tadjikistan), Pakistan, nw India

Distribution: Abu Rawash, Dahshur, Giza, km40 Zafarana road

Flight: males (4-5), females (4-6)

Collections: CGR, WJP 


\section{Tachysphex fasciatus Morice, 1897}

Tachysphex fasciatus Morice 1897a: 306, Pl.6, figs.3 \& 4, + ; holotype $q$ in coll. OUM; loc. typ. Egypt - Zeitoun nr Cairo.

Egyptian synonyms:

Tachysphex fasciatus

Morice, 1897a; de Beaumont, 1940b (ㅇ, nec $\hat{\jmath}=$ speciosissimus, per Pulawski, 1971); Honoré, 1942; de Beaumont, 1947 (ㅇ, nec $\hat{0}=$ speciosissimus, per Pulawski, 1971); Pulawski,

Range: Egypt, Algeria 1971; Bohart \& Menke, 1976.

Distribution: Gebel el Asfar, Zeitoun (near Cairo)

\section{Tachysphex fugax (Radoszkowski, 1877) ssp. fugax (s.s.)}

Tachytes fugax Radoszkowski, 1877: 30, $\hat{0}$; holotype $\delta$ in ZMMU; loc. typ. Uzbekistan Samarkand. [Pulawski, 1971]

Tachytes filicornis Kohl, 1883: 169, + ; holotype $\circ$ in NHMW; loc. typ. France - Marseille. [Pulawski, 1971] Pulawski, 1971, synonymised filicornis with fugax.

Egyptian synonyms:

Tachytes filicornis de Beaumont, 1940b \& 1947; Honoré, 1942.

Tachysphex fugax Pulawski, 1971.

Range: Portugal, Spain, France, Italy, Malta, Yugoslavia, Greece, Cyprus, Canary Is., Morocco, Algeria, Egypt, Arabia, Oman, Israel, Syria Turkey, USSR (Georgia, Azerbaijan, Turkmenistan, Tadjikistan)

Distribution: Abu Zabal, Cairo, Ezbet el Nakhl, Gebel el Asfar, Helwan, Kom Awshim, Saqqara, Tell el Kebir

Flight: males $(2-5,10,12)$, females $(2,4,7,12)$

Collections: CGR

\section{Tachysphex gujaraticus Nurse, 1909}

Tachysphex gujaraticus Nurse, 1909: 516, $\widehat{0},+$; lectotype in coll. BMNH, designated by Pulawski, 1975; loc. typ. India - Bombay State, Deesa. [Pulawski, 1975.]

Tachysphex No. 18, de Beaumont, 1940: 178 (partim; remainder T. erythrophorus Dalla Torre) [Krombein \& Pulawski, 1994]

Tachysphex laniger Pulawski, 1964: 105-107, ô, + ; holotype in coll. WJP; loc. typ. Egypt Abu Rawash. Pulawski, 1975, synonymised laniger with gujaraticus.

Egyptian synonyms:

Tachysphex sp. 18, de Beaumont, 1940: 178 (partim) Pulawski, 1971.

Tachysphex laniger

Pulawski, 1971 \& 1973.

Tachysphex gujaraticus Pulawski, 1975; Bohart \& Menke, 1976;

Krombein \& Pulawski, 1994.

Range: Egypt, Israel, Saudi Arabia, USSR (Turkmenistan,Tadjikistan), w India

Distribution: Abu Rawash, Abu Zabal, Dakhla Oasis (Al Qasr), Fayyum (Karanis), Giza, Kerdasa, Kharga Oasis (El Kharga), KomAwshim, Maadi, Manshiet Radwan, Wadi el Natrun (Bir Hooker)

Flight: males (4-8), females $(5,7-8)$

Collections: CGR, WJP

\section{Tachysphex helveticus Kohl, 1885 ssp. aegyptiacus Morice, 1897}

Tachysphex. helveticus Kohl, 1885: 374, +., holotype in NHMW, loc.typ. Switzerland (ValaisSierre)

Tachysphex aegyptiacus Morice, 1897a: 306, §̂, + ; holotype in OUM, loc. typ. Egypt Koubbeh nr. Cairo.

Egyptian synonyms:

Tachysphex aegyptiacus

Tachysphex helveticus var. aegyptiacus

Tachysphex helveticus aegyptiacus

Menke, 1976; Krombein \& Pulawski, 1994

Range: Egypt
Morice, 1897a; Storey, 1916; Honoré, 1942.

de Beaumont, 1940b.

de Beaumont, 1947; Pulawski, 1971; Bohart \& 
Distribution: Abu Rawash, Abydos, Aswan, Cairo (Koubbeh), Dahshur, Ezbet el Nakhl, Fayyid, Fayyum (Karanis), Gebel el Asfar, Giza, $25 \mathrm{~km} \mathrm{~N}$ of Giza, Helwan, Ismailia, Kerdasa, Kharga Oasis (El Kharga), Kom Awshim, Maadi, Manshiet Radwan, Saqqara

Flight: males (4-5), females (3-4, 6-7)

Collections: CGR

\section{Tachysphex melas Kohl, 1898 ssp. eatoni E. Saunders, 1910}

Tachysphex melas Kohl 1898: 100, q, type in NHMW, loc. typ. N. Mongolia - Irkut. [Pulawski, 1971.]

Tachysphex eatoni E. Saunders, 1910: 525-526, + ; holotype + in BMNH; loc. typ. Algeria Biskra.

Tachysphex melas eatoni E. Saund., stat n., Pulawski, 1971: 79.

Egyptian synonyms:

Tachysphex melas eatoni Pulawski, 1962; Bohart \& Menke, 1976.

Range: Algeria, Egypt

Distribution: Abu Rawash

\section{Tachysphex nitidior de Beaumont, 1940}

Tachysphex nitidior de Beaumont, 1940b: 175, $\hat{\sigma},+$; holotype $\widehat{\partial}$ in coll. Mochi; loc. typ. Egypt Wadi Hoff. Syntype from Ezbet el Nakhl in coll. Alfieri.

Egyptian synonyms:

Tachysphex nitidior de Beaumont, 1940b; Honoré, 1942; de Beaumont, 1947 \& 1950c; Pulawski, 1971.

Range: Gibraltar, Portugal, Spain, France, Switzerland, Germany, Italy, Malta, Yugoslavia, Rumania, Bulgaria, Greece, Crete, Cyprus, Turkey, Morocco, Libya (Tripolitania, Cyrenaica), Egypt, Israel, Lebanon, Iran, Russia (Sarepta, Crimea), Georgia, Kazakhstan, Uzbekistan, Turkmenistan, Tadjikistan

Distribution: Cairo, Ezbet el Nakhl, Fayyum (Hawarah), Kom Awshim, Luxor, Mersa Matruh, Siwa Oasis (Siwa, Zegawa), Wadi Hof

Flight: males (8-9)

Collections: CGR

\section{Tachysphex nitidissimus de Beaumont, 1952}

Tachysphex nitidissimus de Beaumont, 1952: 192-195, figs. 9-11, ô,, ; holotype in MZL; loc. typ. Hoggar (Idjef Melen nr. Hirhakof [Hirhafok per de Beaumont]).

Tachysphex sp. 11 de Beaumont, 1940b: 176

Tachysphex sp. 14 de Beaumont, 1940b: 172

Egyptian synonyms:

Tachysphex sp. 11 de Beaumont, 1940b: 176 de Beaumont, 1952, Pulawski, 1971

Tachysphex sp. 14 de Beaumont, 1940b: 172 de Beaumont, 1952, Pulawski, 1971

Tachysphex nitidissimus Pulawski, 1964 \& 1971.

Range: Bulgaria, Greece, Cyprus, Turkey, Algeria, Egypt, Israel, Lebanon, Syria, Jordan, Oman, USSR (Uzbekistan, Turkmenistan, Tadjikistan)

Distribution: Kom Awshim, Maadi, Wadi Hoff. Sinai - Feiran Oasis

Flight: males (3-4, 10), females (3-4)

Collections: CGR, WJP

\section{Tachysphex nitidus (Spinola, 1805) ssp. ibericus (Saussure, 1867)}

Astata nitida Spinola, 1805: 17; type in coll. IMZUT; loc. typ. Italy - Liguria. [Pulawski, 1971 \& 1972.]

Tachytes Ibericus Saussure, 1867: 68, + ; holotype $q$ in coll. NHMW; loc. typ. Gibraltar. [Pulawski, 1972.]

Egyptian synonyms: Tachysphex ibericus Pulawski, 1971.

Range: s Spain, Canary Is., Morocco, Algeria, Libya (Tripolitania, Fezzan, Cyrenaica), Egypt, Israel, Syria, Turkey, Oman

Distribution: Kom Awshim

Flight: males (2-4, 11-12), females (2) 
Collections: CGR

\section{Tachysphex pompiliformis (Panzer, 1804)}

Larra pompiliformis Panzer, 1805: pl. 13, + ; holotype + in ZSBS; loc. typ. Germany. [Pulawski, 1971.]

Egyptian synonyms:

Tachysphex pectinipes auctt, nec Linnaeus, 1758 de Beaumont, 1940b; Honoré, 1942.

Tachysphex pompiliformis de Beaumont, 1947.

[Note: records from Egypt questionable, according to World Catalogue]

Range: All Europe (including Great Britain, Ireland, Netherlands, Norway, Sweden, Finland, Switzerland, France, USSR (Russia, Siberia, Kazakhstan, Kirghizistan, Georgia, Turkemistan, Tadjikistan), Morocco, Turkey, Iran, nw India, Mongolia

\section{Tachysphex priesneri de Beaumont, 1940}

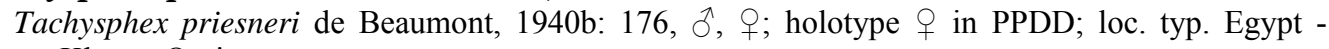
Kharga Oasis.

Egyptian synonyms:
Tachysphex priesneri
de Beaumont, 1940b \& 1947; Pulawski, 1971.

Tachysphex Priesneri

Honoré, 1942.

Range: Algeria, Libya (Tripolitania, Fezzan), Egypt

Distribution: Kharga Oasis (Dush), Wadi Ginah), Wadi um Assaad

Flight: males (10)

Collections: CGR

\section{Tachysphex speciosissimus Morice, 1897}

Tachysphex speciosissimus Morice, 1897a: 308, pl. 6 figs. $11 \&$ 12, + ; holotype + in OUM; loc. typ. Egypt - Koubbeh nr. Cairo.

Egyptian synonyms:

Tachysphex speciosissimus

Tachysphex fasciatus

Morice, 1897a; de Beaumont, 1940b ô nec ${ }^{+}=$ T.fasciatus; Honoré, 1942; de Beaumont, 1947: 207 §̂ nec 9 = T.fasciatus; Pulawski, 1971. de Beaumont, 1940b \& 1947, (ㅇ nec ô, per Pulawski, 1971).

Range: Morocco, Algeria, Egypt, Israel. Syria, Iran

Distribution: Ain Sokhna, 13-22 km n of Ain Sokhna, Cairo (Koubbeh), Kafr Hakim, Maadi, Wadi um Assaad

\section{Tachysphex tarsinus (Lepeletier, 1845)}

Tachytes tarsina Lepeletier, 1845: 243, ô; type in MNHN; loc. typ. France - Dauphinée. [Pulawski, 1971.]

Egyptian synonyms:

Tachysphex tarsinus

de Beaumont, 1940b; Honoré, 1942; de Beaumont, 1947; Pulawski, 1971.

Range: Germany, Poland, France, Spain, Portugal, Switzerland, Italy, Yugoslavia, Bulgaria, Greece, Morocco, Algeria, Libya (Fezzan), Egypt, Turkey, Lebanon, Saudi Arabia, Oman, USSR (Crimea, Sarepta, Kazakhstan), China

Distribution: Abu Rawash, 60km S of Alexandria (desert road), Aswan, Baharia Oasis, Dahshur, Dakhla Oasis (Tineida), Dekhela, (Mariout), Fayyum, Gebel el Asfar, Giza (Pyramids), Kerdasa, Kharga Oasis (Dush, El Kharga), Kom Awshim, Maadi, Wadi el Natrun (Bir Hooker), 35km E of Wadi el Natrun

Flight: males $(4-5,7-8,10)$, females $(4,6-7,10)$

Collections: CGR

\section{Tachysphex unicolor (Panzer, 1809)}

Larra unicolor Panzer, 1809: pl. 16; type lost; neotype $\hat{\text { ô }}$, designated by Pulawski, 1972, in ZSBS; loc. typ. Germany - Bavaria, nr Fürth. Records of nitidus corrected by Pulawski 1972: 817

\section{Egyptian synonyms:}


Tachysphex nitidus auctt nec Spinola, 1838 Storey, 1916; de Beaumont, 1940b; Honoré, 1942; de Beaumont, 1947, 1956a, 1960a, 1966; Pulawski, 1971.

\section{Tachysphex yarrowi de Beaumont, 1960}

Tachysphex (s.s.) yarrowi de Beaumont, 1960a: 239-241, $q$; holotype $q$ in BMNH; loc. typ. Libya - Cyrenaica (Capuzzo).

Egyptian synonyms:

Tachysphex sp. 17 de Beaumont, 1940b: 178 Pulawski, 1971.

Tachysphex yarrowi Pulawski, 1964 \& 1971.

Range: Algeria, Libya (Cyrenaica), Egypt, Israel

Distribution: Abu Rawash, Ben Yusef, Giza, Manshiet Radwan (near Giza), Wadi um Assaad

Flight: males $(3,5)$, females (3-4)

Collections: JdeB, WJP

bicolor species group

\section{Tachysphex denisi de Beaumont, 1936}

Tachysphex denisi de Beaumont, 1936: 197-198, figs. 5, $40 \& 41$, ठ̊ (nec $q=T$. adjunctus Kohl); holotype $\delta$ in NHMW; loc. typ. Algeria - Oran.

Egyptian synonyms:

Tachysphex denisi

Pulawski, 1971.

Range: France, Spain, Morocco, Algeria, Tunisia, Libya, Tripolitania, Cyrenaica), Egypt

Distribution: Mersa Matruh

brevipennis species group

\section{Tachysphex brevipennis Mercet, 1909}

Tachysphex brevipennis Mercet, 1909: 197, ô, , ; syntypes from Spain, held in MNMS.

Tachysphex fulvicornis Turner, 1918: 363, + ; holotype $q$ in BMNH; loc. typ. India - Bengal, Chapra. [Synonymised with brevipennis by Pulawski, 2007: 159]

Tachysphex imperfectus de Beaumont, 1940b: 178, + ; lectotype originally in coll A Mochi, Cairo now in USNM; loc. typ. Egypt - Kerdasa, nr. Cairo (de Beaumont, 1947: 210 illegally designated the holotype from non-type material citing the type locality as Algeria - Biskra). Pulawski, 1975, synonymised imperfectus with fulvicornis.

Tachysphex minutus Nurse, 1909: 516, §,, ; lectotype $\delta$ in BMNH; loc.typ. India (Gujerat), Deesa. Synonymised by Pulawski, 2007: 159

Tachysphex quadrifurci Pulawski 1971: 246-247, ô, $\odot$; holotype in coll. WJP; loc. typ. Turkmenistan - Askhabad, edge of desert. Pulawski in Krombein \& Pulawski, 1994 synonymised quadrifurci with minutus.

Tachysphex sinaiticus Pulawski, 1964: 108-109, $q$; holotype $q$ in coll. WJP; loc. typ. Egypt Sinai, Feiran Oasis. Synonymised by Pulawski, 2007: 160

\section{Egyptian synonyms:}

Tachysphex imperfectus ～de Beaumont, 1940b \& 1947; Honoré, 1942.

Tachysphex fulvicornis Pulawski, 1971; Krombein \& Pulawski, 1994.

Tachysphex quadrifurci Pulawski, 1971; Bohart \& Menke, 1976.

Tachysphex sinaiticus $\quad$ Pulawski, $1971 \&$ \& 1973; Bohart \& Menke, 1976; Krombein \& Pulawski, 1994.

Range: Morocco, Algeria, Tunisia, Libya (Tripolitania), Egypt, Sudan, Israel, Saudi Arabia, S.Yemen, Oman, e.India, Turkmenistan

Distribution: Dahshur, Fayyid, Gebel el Asfar, Giza, Kabrit, Kerdasa, Kom Awshim, Maadi, Manshiet Radwan, Saqqara, Suez, Wadi el Natrun (Bir Hooker), 35km E of Wadi el Natrun, $18-25 \mathrm{~km} \mathrm{~W}$ of Suez, Sinai - Feiran Oasis

Flight: males (4-8), females (4, 6-8, 11)

Collections: CGR, USNM, WJP 
plicosus species group

\section{Tachysphex mediterraneus Kohl, 1883}

Tachysphex mediterraneus Kohl, 1883: 173, + ; holotype + , in NHMW; loc. typ. Italy - Sicily, Valsavoja. [Pulawski, 1971]

Egyptian synonyms: Tachysphex mediterraneus Pulawski, $1964 \& 1971$.

Range: Portugal, Spain, France, Italy, Yugoslavia, Rumania, Bulgaria, Greece, Cyprus, Mauritania, Morocco, Egypt, Israel, Turkey, USSR (Azerbaijan, Kazakhstan, Uzbekistan, Tadzhikistan), Iran

Distribution: Giza

Flight: female (11)

Collections: WJP

\section{Tachysphex plicosus (A.Costa, 1867)}

Tachytes plicosus Kohl, 1883: 173, + ; holotype $\odot$ in MZUN; loc. typ. Italy - Calabria, Vallata dell'Aspromonte. [Pulawski, 1971]

Egyptian synonyms:

Tachysphex plicosus de Beaumont, 1940b; Honoré, 1942; de

Range: France, Italy, Rumania, Yugoslavia, Albania, Greece, Turkey, USSR (Azerbaijan), Morocco, Algeria, Egypt, Soudan, e India

Distribution: Ezbet el Nakhl, Marg

panzeri species group

\section{Tachysphex buyssoni Morice, 1897}

Tachysphex buyssoni Morice, 1897a: 307, pl.6, figs. 7 \& 8, ô, of; holotype in OUM; loc. typ. Egypt - Koubbeh nr Cairo.

Egyptian synonyms:

Tachysphex buyssoni

Tachysphex Buyssoni

Morice, 1897a; de Beaumont, 1940b \& 1947; Pulawski, 1971 \& 1973; Bohart \& Menke, 1976.

Range: Chad (Tibesti), Egypt, Iraq Honoré, 1942.

Distribution: Cairo (Abbasieh, Koubbeh, Heliopolis), Fayyum road, Maadi. Sinai - Wadi Mitla

\section{Tachysphex cheops de Beaumont, 1940}

Tachysphex cheops de Beaumont, 1940b: 163, ô,, ; holotype in USNM; loc.typ. Egypt-Suez road. Egyptian synonyms:

Tachysphex cheops

de Beaumont, 1940b, 1947, 1950c \& 1966;

Tachysphex Cheops Pulawski, 1971 \& 1973; Bohart \& Menke, 1976. Honoré, 1942.

Range: Mauritania, Libya (Cyrenaica), Egypt, Israel

Distribution: Abu Rawash, Agami, 42km NW of Cairo, Dahshur, Fayyum (el Khawagat), Gebel el Asfar, Giza, Kerdasa, Kom Awshim, Maadi, Mersa Matruh, Saqqara, Siwa Oasis, Suez road, Wadi el Natrun. Sinai - El Arish

Flight: males (4-10), females $(4,6-8)$

Collections: CGR

\section{Tachysphex chephren de Beaumont, 1940}

Tachysphex chephren de Beaumont, 1940b:164, §̊, of; holotype in USNM; loc.typ. Egypt-Wadi Hof Egyptian synonyms:

Tachysphex chephren

Tachysphex Chephren

Range: Egypt, Israel

Distribution: Wadi Amraga, Wadi Hoff de Beaumont, 1940b \& 1947; Pulawski, 1971 \& 1973; Bohart \& Menke, 1976.

Honoré, 1942. 


\section{Tachysphex gracilicornis Mercet, 1909}

Tachysphex gracilicornis Mercet, 1909:194, ô, o; holotype in MNMS; loc.typ. Morocco - Melilla. [Pulawski, 1971]

Egyptian synonyms:

Tachysphex gracilicornis de Beaumont, 1940b; Honoré, 1942; de

Range: Morocco, Algeria, Tunisia, Libya (Tripolitania, Cyrenaica), Egypt

Distribution: Sollum

\section{Tachysphex incertus (Radoszkowski, 1877)}

Tachytes incerta Radoszkowski, 1877: 28, O̊, , ; holotype in ZMMU; loc. typ. Uzbekistan - KyzilKum desert. [Pulawski, 1971: 321]

Tachysphex nattereri Kohl, 1888: 144, $q$ (nec $\delta^{\hat{\sigma}}=T$. palopterus Dahlbom), type in NHMW; loc. typ. Sudan. [Pulawski, 1971.]

Egyptian synonyms:

Tachysphex pygidialis Kohl, 1883 de Beaumont, 1940b; Honoré, 1942; de

Tachysphex pygidialis nattereri

Beaumont, 1947 \& 1950c.

Tachysphex incertus nattereri

Pulawski, 1964 \& 1971;

Bohart \& Menke, 1976.

Range: Egypt, Sudan

Distribution: Abu Rawash, Dakhla Oasis (5-10 km E of Tineida), Dahshur, Fayyid, Giza, Ismailia, Kharga Oasis (El Kharga), Kom Awshim, Luxor, Maadi, Saqqara, Wadi el Natrun (Bir Hooker)

Flight: males (4-7), females $(2-5,7)$

Collections: CGR, WJP

\section{Tachysphex aemulus Kohl, 1906}

Tachysphex aemulus Kohl, 1906: 216, §̂,, ; syntypes from Yemen (NHMW)

Tachysphex liriformis tenax Pulawski, 1971: 311, $\hat{0}, \circ$; holotype + in BYS-TAUI; loc. typ. Israel - Jerusalem. Synonymised by Pulawski, 2007: 81

Egyptian synonyms:

In coll CGR there is a specimen provisionally determined as this. Confirmation is required before it is accepted as a member of the Egyptian fauna.

Range: Israel, ? Egypt, Arabia

Distribution: Kerdasa

Flight: males (4)

Collections: CGR (? First record from Egypt)

\section{Tachysphex longipalpis de Beaumont, 1940 ssp. longipalpis (s.s.)}

Tachysphex longipalpis de Beaumont, 1940b: 166, đo, o, type in USNM, loc. typ. Egypt - Giza,.

Egyptian synonyms:

Tachysphex longipalpis

de Beaumont, 1940b; Honoré, 1942; de

Range: Libya (Tripolitania), Egypt

Beaumont, 1947; Pulawski, 1964, $1971 \& 1973$.

Distribution: Abu Rawash, Cairo (Shubra), El Timid, Fayyid, Giza,

Flight: males (4)

Collections: WJP

\section{Tachysphex micans (Radoszkowski, 1877)}

Tachysphex micans Radoszkowski, 1877: 29, O,, ; type in ZMMU, loc. typ. Kazakhstan - KyzilKum desert,. [Pulawski, 1971.]

Egyptian synonyms:

Tachysphex micans

de Beaumont, 1940b; Honoré, 1942; de Beaumont, 1947; Pulawski, 1964 \& 1971.

Range: Morocco, Libya (Tripolitania, Fezzan), Egypt, Sudan, Oman, Iran, USSR (Kazakhstan, Uzbekistan, Turkmenistan)

Distribution: Abu Rawash, Dahshur, Katta, Suez road, Wadi Digla. Sinai - Wadi Feiran

Flight: males (5), females (5) 
Collections: WJP

\section{Tachysphex mycerinus de Beaumont, 1940}

Tachysphex mycerinus de Beaumont, 1940b: 166, §̂, o, type in PPDD, loc. typ. Egypt - Cairo.

Egyptian synonyms:

Tachysphex mycerinus

de Beaumont, 1940b \& 1947; Pulawski, 1964 \& 1971.

Tachysphex Mycerinus

Honoré, 1942.

Range: Morocco, Tunisia, Egypt

Distribution: Abu Rawash, Cairo, Dahshur, Giza, Kerdasa, Kom Awshim, Maadi, Massara

Flight: males $(3-5,7-9,11)$, females $(4-5,8)$

Collections: CGR, WJP

\section{Tachysphex palopterus (Dahlbom, 1845)}

Tachytes paloptera Dahlbom, 1845: 470, ô; type in NRS, loc. typ. Egypt. [Pulawski, 1971.]

Egyptian synonyms:

Tachysphex palopterus

de Beaumont, 1940b; Honoré, 1942; de

Tachysphex sp. no. 1, de Beaumont, 1940b. Pulawski, 1971.

Range: Morocco, Algeria, Tunisia, Egypt, Israel, Arabia, Oman

Distribution: Dahshur, Gebel el Asfar, Giza, Helwan, El Khanka, Kharga Oasis, Kom Awshim, Maadi, Mariut, El Qassasin, Saqqara, Sollum

Flight: males (3-5), females (4-5)

Collections: CGR, WJP

\section{Tachysphex panzeri (Vander Linden, 1829)}

Tachysphex panzeri Vander Linden, 1829: 22, $\widehat{O}$ (nec $\odot=T$. pseudopanzeri de Beaumont), type lost; loc. typ. Spain; neotype in RMNH, designated by Pulawski, 1971; loc. typ. Spain Toledo. [Pulawski, $1971 \&$ 1975.]

Tachytes Oraniensis Lepeletier de Saint Fargeau, 1845: 253, O,, , type in MNHN, loc. typ. Algeria - Oran. [Pulawski, 1971.]

Tachytes pulverosus Radoszkowski, 1886: 32, ô, of; syntypes in ZMJU, loc. typ. Uzbekistan Samarkand. [Pulawski, 1971 \& 1975.]

Tachysphex panzeri pulverosus stat. nov. [Pulawski, 1971.]

Egyptian synonyms:

Tachysphex panzeri

Storey, 1916, (without reference to subspecies); de Beaumont, 1940b; Honoré, 1942; de Beaumont, 1966; Pulawski, 1971.

Tachysphex panzeri oraniensis

de Beaumont, 1940b; Honoré, 1942; de

Tachysphex panzeri

Tachysphex panzeri pulverosus

Beaumont, 1947 \& 1966; Pulawski, 1971.

de Beaumont, 1940b per Pulawski, 1971

Pulawski, 1971.

Range: Netherlands, Belgium, Germany, Poland, Czechoslovakia, Hungary, Portugal, Spain, France, Switzerland, Italy, Yugoslavia, Rumania, Bulgaria, Greece, Turkey, Morocco, Algeria, Tunisia, Libya, Egypt, Sudan, Israel, Jordan, Syria, Russia (Crimea), Kazakhstan, Uzbekistan, Turkmenistan, Azerbaijan, Tadjikistan, Iran

Distribution: Amrieh (near Alexandria), Agami (near Alexandria), Dahshur, Dakhla Oasis (Tineida), Gebel el Asfar, Giza (Pyramids), Kerdasa, Kharga Oasis (El Kharga), Kom Awshim, Maadi, Saqqara, Wadi Ramila

Flight: males (4-5, 7-10), females $(7,9)$

Collections: CGR

\section{Tachysphex persa Gussakovskij, 1933 ssp. persa (s.s.)}

Tachysphex persa Gussakovskij, 1933: 285, +, type in ZIL, loc. typ. Iran - Kirman: str. Sardag, Chakh-i-Zaman. [Pulawski, 1971]

Egyptian synonyms:

Tachysphex persa

Pulawski, 1971.

Range: Turkey, Syria, Lebanon,Israel, Egypt, USSR (Armenia), Iran 
Distribution: Abu Rawash, Giza, Wadi Hoff

Tachysphex persa Gussakovskij, 1933 ssp. catharinae Pulawski, 1964

Tachysphex catharinae Pulawski, 1964: 86-88, $\hat{\sigma},+$, holotype $\hat{\sigma}$ in coll. WJP, loc. typ. Egypt Sinai, St Catherine's.

Egyptian synonyms:

Tachysphex persa catharinae Pulawski, 1971 \& 1973; Bohart \& Menke, 1976.

Range: Egypt, Israel, Syria

Distribution: Sinai - St. Catherine's Monastery

Flight: males (4), females (4)

Collections: WJP

\section{Tachysphex ptah Pulawski, 1964}

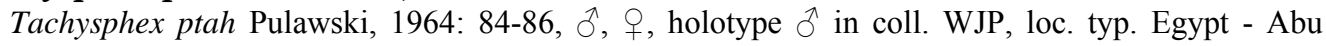
Rawash.

Egyptian synonyms: Tachysphex ptah

Pulawski, 1971 \& 1973; Bohart \& Menke, 1976.

Range: Egypt, Israel, Aden

Distribution: Abu Rawash, Dahshur, Giza

Flight: males $(4-5,11)$, females $(4,11)$

Collections: WJP

\section{Tachysphex ramses Pulawski, 1971}

Tachysphex ramses Pulawski, 1971: 295-297, ô, $q$, holotype $q$ in USNM, Washington, loc. typ. Egypt - Manshiet Radwan.

Egyptian synonyms:

Tachysphex ramses

Pulawski, 1971; Bohart \& Menke, 1976.

Range: Egypt

Distribution: Beni Youssef, Manshiet Radwan

Flight: males (4), females $(4,6)$

Collections: AM, USNM

\section{Tachysphex sericans Gussakovskij, 1952 ssp. gracilis Pulawski, 1971}

Tachysphex sericans Gussakovskij, 1952: 241, $\hat{O}^{\lambda}$, + , type in ZIL, loc. typ. Tadjikistan - Aïvadj. [Pulawski, 1971.]

Tachysphex sericans gracilis ssp. n., Pulawski, 1971: 326-328, đ̂,, ; holotype in Musée Zoologique de Lausanne, loc. typ. Algeria - Biskra.

Egyptian synonyms:

Tachysphex sericans gracilis Pulawski, 1971; Bohart \& Menke, 1976.

Range: Algeria, Egypt

Distribution: Siwa Oasis (Siwa)

Flight: males (5-7), females (5-6)

Collections: Mus. Zool., Lausanne, WJP

geniculatus species group

\section{Tachysphex geniculatus (Spinola, 1839)}

Lyrops geniculata Spinola, 1839: 480, + ; holotype in MRSN; loc. typ. Egypt (Pulawski, 1964 \& 1971)

Tachysphex sp. 8 de Beaumont, 1940b: 168.

Egyptian synonyms:

Tachysphex sp. 8 de Beaumont, 1940b: 168. Pulawski, 1964 \& 1971

Tachysphex? geniculatus

de Beaumont, 1952.

Tachysphex geniculatus

Pulawski, 1964:88 \& 1971: 346; Bohart \& Menke, 1976.

Range: Algeria, Egypt, Syria, Arabian peninsula 
Distribution: Abu Rawash, Abydos, Fayyum (Hawara, El Khawagat, 5km E of Lahun), Gebel el Asfar, Giza, Giza (Pyramids), Kom Awshim, Luxor, Maadi, Saqqara, Tell el Amarna, Wadi Digla

Flight: males (2-4), females $(2,11)$

Collections: CGR, WJP

\section{Tachysphex horus de Beaumont, 1940}

Tachysphex horus de Beaumont, 1940b: 168, + (nec $\hat{O}=$ T.luxuriosus Morice per Pulawski, 1964, 1971); holotype $q$ in PPDD, loc. typ. Egypt - Heliopolis.

\section{Egyptian synonyms:}

Tachysphex horus

de Beaumont, 1940b, $q$ (nec đ); Honoré, 1942; de Beaumont, 1947, ㅇ (nec đ̂); Pulawski, 1964: 91,

Range: Libya (Fezzan), Egypt, Israel 1971: 350 \& 1973; Bohart \& Menke, 1976.

Distribution: Abu Rawash, 13-22 km N of Ain Sokhna, Giza, Heliopolis, Kerdasa, Kom Awshim, Maadi, Saqqara

Flight: males (3-4), females (4-5)

Collections: CGR, WJP

\section{Tachysphex inextricabilis Pulawski, 1971}

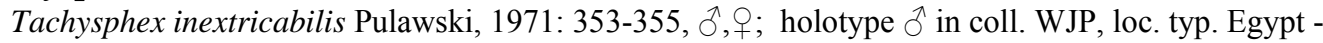
Kom Awshim.

Egyptian synonyms:

Tachysphex inextricabilis

Tachysphex seth

Range: Egypt, Israel, Jordan, Syria

Distribution: Kom Awshim

Flight: males (4), females (4)

Collections: WJP

\section{Tachysphex luxuriosus Morice, 1897}

Tachysphex luxuriosus Morice, 1897a: 307-308, pl. 6 figs. $9 \&$ 10, $q$; holotype $q$ in OUM; loc. typ. Egypt - Koubbeh nr Cairo.

Tachysphex horus de Beaumont, 1940: 168, đ̊ (nec o per Pulawski, 1971) [Pulawski, 1964.]

Tachysphex seth Pulawski, 1964: 92-94, ô, O+; holotype in coll. WJP; loc. typ. Egypt - Kom Awshim. Pulawski, 1971, corrected this: "ठ (nec $q=T$. inextricabilis sp.n.)".

Egyptian synonyms:

Tachysphex luxuriosus

Tachysphex horus

Tachysphex seth

Morice, 1897a; de Beaumont, 1940b; Honoré, 1942; de Beaumont, 1947; Pulawski, 1964; Osborn \& Krombein, 1969; Pulawski, 1971 \& 1973; Bohart \& Menke, 1976. The record of Osborne \& Krombein, 1969, is from Gebel 'Uweinat, but from the Sudanese part. de Beaumont, 1940 \& 1947, đ̃ (nec 우) Pulawski, 1964, đ̊ (nec + )

Range: Sudan (Gebel 'Uweinat), Libya (Tripolitania, Fezzan, Cyrenaica), Egypt

Distribution: Dahshur, Cairo (Koubbeh), Gebel el Asfar, Kom Awshim, Maadi, Mellaha

Flight: males (4-5), females (4-5)

Collections: WJP

\section{Tachysphex niloticus Pulawski, 1964}

Tachysphex niloticus Pulawski, 1964: 90-91, ô, + ; holotype in coll. WJP; loc. typ. Egypt - Abu Rawash.

Egyptian synonyms:

Tachysphex niloticus

Pulawski, 1964 \& 1971; Bohart \& Menke, 1976.

Range: Egypt

Distribution: Abu Rawash, Abydos, Giza, Saqqara

Flight: males (3-4), females (3-4) 
Collections: WJP

julliani species group

Tachysphex argentatus Gussakowskij, 1952

Tachysphex argentatus Gussakovskij, 1952: 242, $\widehat{\delta}$ (nec $q=T$. pectoralis Pulawski); holotype in ZIL; loc. typ. Tadjikistan - Diouchanbe. [Pulawski, 1971.]

Egyptian synonyms:

Tachysphex julliani Pulawski, 1964, misidentification corrected in Tachysphex argentatus 1971.

Pulawski, 1971: 369 \& 1973; Bohart \& Menke, 1976.

Range: Egypt, Israel, Syria, Turkey, USSR (Turkmenistan, Tadjikistan)

Distribution: Maadi, Wadi Digla

Flight: males (5)

Collections: WJP

\section{Tachysphex crocodilus Pulawski, 1971}

Tachysphex crocodilus Pulawski, 1971: 373-376, ô, + ; holotype + in USNM, Washington; loc. typ. Egypt - Kom Awshim.

Egyptian synonyms: Tachysphex crocodilus Pulawski, 1971; Bohart \& Menke, 1976.

Range: Egypt

Distribution: Kom Awshim

Flight: males (5), females (5)

Collections: USNM

\section{Tachysphex deserticola de Beaumont, 1940}

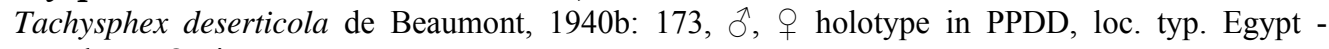
Kharga Oasis.

Egyptian synonyms:

Tachysphex deserticola de Beaumont, 1940b; Honoré, 1942; de Beaumont, 1947; Pulawski, 1964; Osborn \& Krombein, 1969; Pulawski, 1971; Bohart \& Menke, 1976. The record of Osborne \& Krombein, 1969, is from Gebel 'Uweinat, but from the Sudanese part.

Range: Libya (Cyrenaica), Egypt, Sudan (Gebel el 'Uweinat)

Distribution: Abu Rawash, Baharia Oasis, Dahshur, Kharga Oasis, Kom Awshim, Manshiet Radwan, Nabardi (Nubian desert), Saqqara, Wadi Fatira el Beida (near Mons Claudianus)

Flight: males (4-5), females (4-5)

Collections: CGR, WJP

\section{Tachysphex desertorum F. Morawitz, 1894}

Tachysphex desertorum F. Morawitz, 1894: 342, + ; holotype $q$ in ZIL; loc. typ. Turkmenistan Serax. [Pulawski, 1971.]

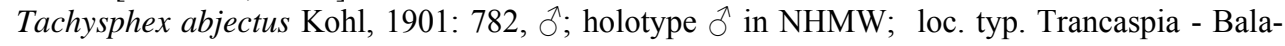
Ischem. [Pulawski, 1971.] Pulawski, 1971 synonymised abjectus with desertorum.

Egyptian synonyms:

Tachysphex abjectus

de Beaumont, 1940b; Honoré, 1942; de Tachysphex desertorum Beaumont, 1947, 1958d \& 1960a.

Pulawski, 1971 \& 1973.

Range: Algeria, Libya (Cyrenaica), Egypt, Israel, Iraq, Iran, USSR, Kazakhstan, Uzbekistan, Turkmenistan), Iran, China

Distribution: Suez, Wadi Digla, Wadi Hoff

Flight: males (4), females (4)

Collections: CGR 


\section{Tachysphex julliani Kohl, 1883}

Tachysphex Julliani Kohl, 1883: 177, Ô, + ; holotype in NHMW; loc. typ. France - Marseille. [Pulawski, 1971.]

Egyptian synonyms:

Tachysphex julliani

de Beaumont, 1940b; Honoré, 1942; de Beaumont, 1947; Pulawski, 1971 (nec $1964=T$. argentatus, corrected in 1971).

Range: Portugal, Spain, France, Italy, Bulgaria, Greece, Cyprus, Turkey, Lebanon, Libya (Cyrenaica), Egypt, Israel, USSR (Crimea, Kazakhstan, Uzbekistan, Turkmenistan, Tadjikistan), Iran

Distribution: Maadi, Wadi Abu Handal, Wadi Hoff

Flight: males (5)

Collections: WJP

\section{Tachysphex vestitus Kohl, 1892}

Tachysphex vestitus Kohl, 1892: 217, $\jmath^{\Uparrow}$; holotype $\sigma^{\lambda}$ in NHMW; loc. typ. Algeria - Biskra. [Pulawski, 1971.]

Egyptian synonyms: Tachysphex vestitus

Storey, 1916; de Beaumont, 1940b; Honoré, 1942; de Beaumont, 1947, 1950c \& 1958d; Pulawski, $1964 \& 1971$.

Range: Mauritania, Morocco, Algeria, Libya (Tripolitania, Cyrenaica), Egypt, Sudan, Israel Distribution: Abu Rawash, 13-22 km N of Ain Sokhna, Baharia Oasis, Bir Dibia $\left(22^{\circ} 12^{\prime} \mathrm{N}\right.$, 293'ㄹ'E), Dahshur, Fayyum (El Khawagat), Giza, Kerdasa, Kharga Oasis (Dush), Kom Awshim, Maadi, El Qassassin, Saqqara, Siwa Oasis (El Arig), 18-25 km W of Suez, Wadi um Assaad, Wadi Assiouti, Wadi Fakira el Beida (near Mon Claudianus), Wadi el Natrun, Wadi er Rayan

Flight: males (4-5, 9), females (4-6, 9-11)

Collections: CGR, WJP

\section{schmiedeknechti species group}

\section{Tachysphex schmiedeknechti Kohl, 1883}

Tachysphex Schmiedeknechti Kohl, 1883: 170,, ; syntypes in NHMW; loc. typ. Greece - Egina (Aegina), now Aiyina. [Pulawski, 1971.]

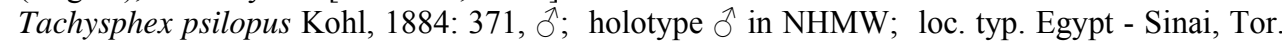
[Pulawski, 1971.]

Egyptian synonyms:

Tachysphex schmiedeknechti

de Beaumont, 1940b, 1947 \& 1950c; Pulawski, 1971.

Tachysphex Schmiedeknechti

Honoré, 1942.

Range: Mauritania, Morocco, Algeria, Libya (Tripolitania, Fezzan), Egypt, Greece,Cyprus, Turkey, Syria, Oman, USSR (Kazakhstan, Uzbekistan, Turkmenistan, Tadjikistan), Iran, w India

Distribution: Abu Rawash, Baharia Oasis, Dahshur, Dakhla Oasis, Fayyum (Karanis), Galala, Gebel el Asfar, Giza (Pyramids), 25 km N of Giza, Goubbet el Bous, Helwan, Kerdasa, Kharga Oasis (Dush), Kom Awshim, Maadi, Saqqara, Siwa Oasis. Sinai - Tor

Flight: males (1, 2-6, 10-12), females (4-5, 10-11)

Collections: CGR

isis species group

\section{Tachysphex isis de Beaumont, 1940}

Tachysphex isis de Beaumont, 1940b: 171, $\hat{0},+$; holotype $q$ in coll. Alfieri, now ESEC, loc. typ. Egypt - Wadi Rishrash.

Egyptian synonyms:

Tachysphex isis

Tachysphex Isis

Range: Libya (Cyrenaica), Egypt, Syria de Beaumont, 1940b \& 1947: 179; Pulawski, 1971: 395.

Honoré, 1942: 56. 
Distribution: Wadi Hoff, Wadi Rishrash, Wadi el Tih

erythropus species group

Tachysphex costae (De Stefani, 1881) ssp. costae (s.s.)

Tachytes Costae De Stefani, 1881: 42, + ; holotype $q$; loc. typ. Italy - Sicily, Sciacca (depository unknown). [Pulawski, 1971.]

Egyptian synonyms:

Tachysphex costae de Beaumont, 1947: 175; Pulawski, 1971: 400. Tachysphex costai de Beaumont, 1966.

Range: Spain, France, Italy, Malta, Rumania, Bulgaria, Greece, Cyprus, Crete, Morocco, Algeria, Libya (Tripolitania, Cyrenaica), Egypt, Israel, Turkey, USSR (Astrakhan, Kazakhstan, Uzbekistan, Turkmenistan, Tadjikistan), Iran

Distribution: Amrieh (near Alexandria)

\section{Tachysphex erythropus (Spinola, 1839)}

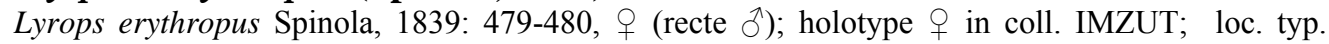
Egypt. Pulawski, 1971 \& 1975.

Tachysphex fluctuatus Gerstaecker of Kohl, 1885a: 350.

Tachysphex heliopolites Morice, 1897a: 306-307, pl.6 figs. $5 \& 6$,, (nec $\widehat{\sigma}=T$. albocinctus Lucas); lectotype $\bigcirc$ in OUM; loc. typ. Egypt - Zeitoun nr Cairo.

Tachysphex mantivora de Beaumont, 1940b: 169 for Tachysphex fluctuatus Gerstaecker of Kohl, 1885.

Egyptian synonyms:

Lyrops erythropus Spinola, 1839.

Tachysphex heliopolites Morice, 1897a \& 1911.

Tachysphex fluctuatus Honoré, 1942

Tachysphex mantivora de Beaumont, 1940b.

Tachysphex mantivorus de Beaumont, 1947: 172 \& 1950c.

Tachysphex erythropus de Beaumont, 1966; Pulawski, 1971: 408; Krombein \& Pulawski, 1994.

Range: Portugal, Spain, Greece, Cyprus, Turkey, Morocco ( = ?Spanish Sahara), Algeria, Libya (Tripolitania, Fezzan, Cyrenaica), Egypt, Sudan (Gebel 'Uweinat), Israel, Arabia, Oman, USSR (Azerbaijan, Kazakhstan, Uzbekistan, Turkmenistan, Tadjikistan), Iran, w India

Distribution: Abu Rawash, Abukir, Alexandria, Amrieh, Beni Youssef, Cairo,Dakhla Oasis (Budkhula, Tineida), Fayyum, Gebel el Asfar, Giza, Helwan, Kerdasa, Kom Awshim, Maadi, Saqqara, Sidi Abdel Rahman, Siwa Oasis (El Arig, Ilrhabit Nachou, Koreishid), Suez Road, Wadi Digla, Wadi el Natrun. Sinai - El Moussa, Wadi Watir

Flight: males (4-9), females (10)

Collections: CGR

\section{Tachysphex grandissimus Gussakovskij, 1933}

Tachysphex grandissimus Gussakovskij, 1933: 282, $q$ (nec $\hat{\delta}=T$. sordidus Dahlbom, per Pulawski, 1971); lectotype + in ZIL; loc. typ. Iran - Bampur, Kaskine. [Pulawski, 1971.]

Egyptian synonyms:

Tachysphex grandissimus de Beaumont, 1940b: 169; Honoré, 1942: 56; de Beaumont, 1947: 177 \& 1950c; Pulawski, 1971: 420.

Range: Morocco, Libya (Cyrenaica), Egypt, Israel, Arabian peninsula, USSR (Turkmenistan, Tadjikistan), Iran

Distribution: Dahshur, Dakhla Oasis, Giza, Kom Awshim, Siwa Oasis (Lake Shiata), Wadi Digla, Wadi el Tih. Sinai - Romani

\section{Tachysphex detritus Arnold, 1924}

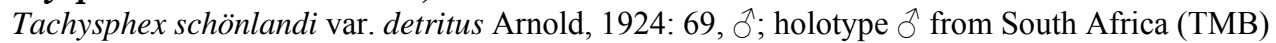

Tachysphex maidli de Beaumont, 1940b: 169, ô, + ; holotype in USNM, loc. typ. Egypt - Sinai, El Arish. Synonymised with detritus by Pulawski, 2007: 240

Egyptian synonyms: 
Tachysphex maidli

Tachysphex Maidli

Range: Morocco, Algeria, Tunisia, Egypt, Bahrein, USSR (Turkmenistan, Tadjikistan)

Distribution: Damietta, Helwan, Mariout, Suez road, Wadi Digla. Sinai - El Arish

\section{Tachysphex osiris de Beaumont, 1940}

Tachysphex osiris de Beaumont, 1940b: 170-171, ô, of; type in BMNH, loc. typ. Sudan - Bir Um Nabardi, $160 \mathrm{~km}$ SE of Wadi Halfa.

Egyptian synonyms:

Tachysphex osiris

Tachysphex Osiris

Range: Algeria, Chad, Libya (Cyrenaica), Egypt

Distribution: Aswan, Giza, Korosko, Siwa Oasis (Abu Hamed, Sitra)

\section{albocinctus species group}

\section{Tachysphex albocinctus (Lucas, 1848)}

Tachytes albo cincta (sic) Lucas, 1848: 250,, ; holotype $q$ in MNHN; loc. typ. Algeria - La Calle. [Pulawski, 1971.]

Tachysphex nubilipennis de Beaumont, 1950c: 18-20, $\widehat{\jmath}$, + ; holotype in BMNH, loc. typ. Egypt - Siwa Oasis. Synonymised by Pulawski, 2007: 93

\section{Egyptian synonyms:}

Tachysphex albocinctus

Tachysphex nubilipennis

de Beaumont, 1940b; Honoré, 1942; de Beaumont, 1947; Sayed et al, 1964; de Beaumont, 1966; Pulawski, 1971.

de Beaumont, 1950c; Pulawski, 1971; Krombein \& Pulawski, 1994.

Range: Portugal, Spain, Greece, Morocco, Algeria, Libya (Tripolitania, Cyrenaica), Egypt, Israel, Jordan, Syria, Pakistan, w. India

According to Pulawski (1971), this species is distributed widely over Africa, reaching the Cape province.

Distribution: Abu Rawash, Amrieh, Dahshur, Dakhla Oasis ( El Gedida, Tineida), Faraskour, Fayyum (Karanis, Lake Qarun), Gebel el Asfar, Giza, Kharga Oasis (Dush, El Kharga), Kom Awshim, Saqqara, Mersa Matruh, Siwa Oasis (El Arig, Siwa)

Flight: males $(4,6,8)$, females (8)

Collections: CGR

\section{Tachytes Panzer, 1806}

obsoletus species group

\section{Tachytes archaeophilus Pulawski, 1962}

Tachytes archaeophilus Pulawski, 1962: 373-375, §̂, $q$; holotype $q$ in coll. WJP; loc. typ. Mersa Matruh. 15.vi.1957

Egyptian synonyms:

Tachytes Frey-Gessneri Kohl

Tachytes archaeophilus

Range: Egypt, Israel, Jordan, Oman

Distribution: Amrieh, Mersa Matruh

Flight: males (7), females (6)

Collections: WJP
Honoré, 1942, partim [misidentification, per Pulawski, 1962]

Pulawski, 1973; Bohart \& Menke, 1976. 
Tachytes biskrensis E. Saunders, 1910

Tachytes biskrensis E. Saunders, 1910: 521-522, đ, ค; holotype in BMNH; loc. typ. Algeria Biskra.

Egyptian synonyms:

Tachytes biskrensis

Pulawski, 1962: 381

Range: Algeria, Egypt, Sinai

Distribution: Wadi Digla, Wadi Hoff. Sinai - El Arish

Flight: males (5-8), females (6)

Collections: $\mathrm{BM}(\mathrm{NH})$

\section{Tachytes fucatus Arnold, 1951}

Tachytes fucata Arnold, 1951: 149, $\odot$; lectotype $\odot$ in BMNH, (designated by Pulawski, 1975); loc. typ. Mauritania - Aleg.

Tachytes serapis Pulawski, 1962: 379-381, ô,, ; holotype $\odot$ in coll. de Beaumont in MZL; loc. typ. Egypt - Helwan. Pulawski, 1975, synonymised serapis with fucatus.

Egyptian synonyms:

Tachytes serapis

Tachytes fucatus

Pulawski, 1973

Pulawski, 1975; Bohart \& Menke, 1976.

Range: Egypt, Mauritania, Jordan, Sudan

Distribution: Fayyid, Fayyum (Karanis), Helwan, El Mallah

Flight: males (6-9), females (7-9)

Collections: CGR, JdeB

\section{Tachytes levantinus Pulawski, 1962}

Tachytes levantinus Pulawski, 1962: 361-364, ô $q$ type in coll. de Beaumont in MZL; loc. typ. Syria - Damascus, Kissoue road.

Egyptian synonyms:

Range: Egypt, Sinai, Syria, Turkey, Iran, sw USSR

Distribution: Sinai - Wadi um Mitla

Flight: males (4)

Collections: CGR, JdeB

\section{Tachytes niloticus Turner, 1918}

Tachytes nilotica Turner, 1918: 94, + ; holotype $\odot$ in BMNH; loc. typ. Egypt - environs of Cairo. [Pulawski, 1965b.]

Egyptian synonyms: Tachytes niloticus

de Beaumont, 1950c; Pulawski, 1962: 386, 1965b: 573.

Range: Morocco, Libya (Cyrenaica), Egypt, Sinai, Oman, sw USSR

Distribution: Abu Rawash, Fayyum, Gholbet el Bous, Maadi, Siwa Oasis, Wadi Hoff . Sinai Romani

Flight: males $(5-6,8)$, females $(7-8)$

Collections: $\mathrm{BM}(\mathrm{NH})$

\section{Tachytes nomarches Pulawski, 1962}

Tachytes nomarches Pulawski, 1962: 367,, ; holotype $\odot$ in coll. de Beaumont in MZL; loc. typ. Egypt - Halaib.

Egyptian synonyms: Tachytes nomarches

Bohart \& Menke, 1976.

Range; Egypt

Distribution: Halaib

Flight: females (1)

Collections: JdeB

\section{Tachytes obsoletus (Rossi, 1792) ssp. obsoletus (s.s.)}

Apis obsoleta Rossi, 1792: 143; whereabouts of type unknown; loc. typ. Italy - Etruria - Tuscany. [Pulawski, 1962.]

Egyptian synonyms: 
Tachytes absoletus (lapsus) Innes, 1911.

Innes is citing a Walker label on a specimen from the Sinai (Wadi Feiran). This Walker record is a possibility inasmuch as Pulawski, 1962, cites the species from Israel.

\section{Tachytes obsoletus (Rossi, 1792) ssp. tricoloratus (Turton, 1802)}

Tachytes tricolor (Fabricius, 1793), nec Panzer, 1806, holotype NW Africa (lost); neotype $\hat{\sigma}$ from Morocco (ZMK).

Sphex tricolorata Turton, 1802: 492. [Pulawski, 1962.]

Egyptian synonyms:

Tachytes tricolor

Honoré, 1942.

There must be some doubt about Honoré's determination, because this subspecies is one from nw Africa.

\section{Tachytes priesneri Pulawski, 1962}

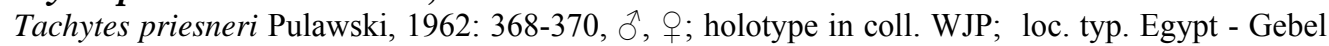
Elba (Wadi Aïdeb).

Egyptian synonyms:

Tachytes priesneri

Pulawski, 1962.

Range: Sudan, Egypt, Oman

Distribution: Gebel Elba

Flight: males (1), females (2-3)

Collections: JdeB, WJP

\section{Tachytes tarsalis (Spinola, 1839)}

Lyrops tarsalis, Spinola, 1839: 478-479, đ̊; holotype in IMZUT; loc. typ. Egypt. Pulawski, 1962

Egyptian synonyms: Tachytes tarsalis

Range: Egypt, Iran, sw USSR

Distribution: Giza, Hawamdieh, Kerdasa, Maadi

Flight: males (5-6)

Collections: Turin

\section{maculicornis species group}

\section{Tachytes diversicornis Turner, 1918}

Tachytes diversicornis Turner, 1918: 94, §ิ,, ; lectotype $\delta$ in coll. BMNH, designated by Pulawski, 1975; loc. typ. Pakistan - Karachi. [Pulawski, 1962 \& 1975.]

\section{Egyptian synonyms:}

Tachytes turcomannica Radoszkowski Honoré, 1942 (misidentification, per Pulawski

Tachytes Radoszkowskii de Beaumont 1962: 399).

Tachytes diversicornis

Honoré, 1942 (misidentification, per Pulawski 1962: 399).

Range: Ghana, Mali, Ethiopia, Sudan, Egypt, Israel, Oman, Pakistan

Distribution: Gebel Elba, Hawamdieh, Helwan, Kharga Oasis (Dush), Maadi

Flight: males $(1,5-7)$, females $(6,9)$

Collections: $\mathrm{BM}(\mathrm{NH}), \mathrm{CGR}$

\section{Tachytes maculicornis E. Saunders, 1910}

Tachytes maculicornis Saunders, 1910: 523, $\hat{0}$,,+ ; holotypes in coll. OUM; loc. typ. Algeria Biskra.

Egyptian synonyms:

Tachytes maculicornis ～de Beaumont, 1950c \& 1958d; Pulawski, 1962: 391.

Range: Morocco, Algeria, Tunisia, Libya (Tripolitania, Fezzan), Egypt

Distribution: [Siwa Oasis]

Collections: Oxford 


\section{Tachytes trichopygus Pulawski, 1962}

Tachytes trichopygus Pulawski, 1962: 403-404, $\widehat{O}$; holotype $\widehat{\delta}$ in coll. de Beaumont in MZL; loc. typ. Egypt - Sinai (Wadi Feiran).

Egyptian synonyms:

Tachytes trichopygus Pulawski, 1962 \& 1973; Bohart \& Menke, 1976.

Range: Sinai

Distribution: Sinai - Wadi Feiran

Flight: males (5)

Collections: JdeB

etruscus species group

\section{Tachytes brunneus Pulawski, 1962}

Tachytes brunneus Pulawski, 1962: 403-404, ô; holotype $\widehat{\jmath}$ in coll. WJP, loc. typ. Egypt - Gebel Elba.

Egyptian synonyms:

Tachytes brunneus

Pulawski, 1962.

Range: Egypt

Distribution: Gebel Elba

Flight: males (1)

Collections: WJP

comberi species group

\section{Tachytes comberi Turner, 1917}

Tachytes comberi Turner, 1917: 201, đ,,+ ; lectotype $q$ in coll. BMNH; loc. typ. Pakistan Karachi. [Pulawski, 1975.]

Tachytes Patrizii Guiglia, 1932: 475, ${ }^{\lambda}$; holotype ${ }^{\lambda}$ in Genoa Museum, loc. typ. Libya - Kufra oasis. [Guiglia, 1939; Pulawski, 1962 \& 1975.]

Egyptian synonyms:

Tachytes patrizii

Pulawski, 1962: 412; Sayed et al, 1964.

Range: Mauritania, Libya (Tripolitania, Fezzan), Egypt, se Arabia, Oman, Pakistan

Distribution: Borgash, Kafr Katati, Gebel Elba

Flight: males (1-3, 8), females (7)

Collections: Genoa Mus.

basilicus species group

\section{Tachytes basilicus Guérin-Méneville, 1844}

Lyrops basilicus Guérin-Méneville, 1844: 440, + ; holotype + in MSNG; loc. typ. Senegal. [Pulawski, 1962: 416.]

Egyptian synonyms:

Tachytes basilicus

Pulawski, 1962: 416; Bohart \& Menke, 1976.

Range: Mali, Niger, Nigeria, Senegal to Algeria, Egypt, Sudan, Eritrea

Collections: Genoa Mus.

ambidens species group

\section{Tachytes alfierii Pulawski, 1962}

Tachytes alfierii Pulawski, 1962: 441-443, ô, o ; holotype in coll. WJP, loc. typ. Egypt - Wadi Digla.

Egyptian synonyms:

Tachytes alfierii

Range: Egypt, Libya (Cyrenaica), sw USSR

Distribution: Fayyum, Geneiva, Kom Awshim, Maadi, Wadi Digla, Wadi el Tih (near Cairo)

Flight: males $(5-6,10)$, females $(4,8,10)$

Collections: JdeB, WJP 


\section{Tachytes argyreus (F. Smith, 1856)}

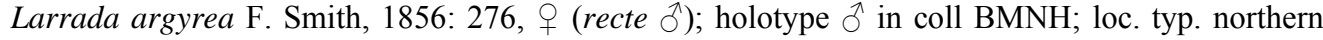
India or? Pakistan. [Pulawski, 1975.]

Tachytes melanopyga, nob., Costa, 1893, 99,, ; holotype + in coll. MZUN; loc. typ. Tunisia. Pulawski, 1975, synonymised melanopyga with argyreus.

Egyptian synonyms:

Tachytes ambidens Kohl, 1884

Storey, 1916, following a misidentification by Kohl of his own species which was cited by Morice, 1911.

Tachytes melanopygus

de Beaumont, 1950; Pulawski, 1962: 435.

Range: Algeria, Tunisia, Libya (Tripolitania, Cyrenaica), Egypt, Israel, Jordan, Iraq, sw USSR, n India

Distribution: Amrieh, Baharia Oasis, Baltim, Dakhla Oasis (Al Qasr), Fayyum (Karanis, 28km W of Shakshuk), Gebel el Asfar, Helwan, Kerdasa, Kharga Oasis (Dush, el Kharga), Kom Awshim, Maadi, Saqqara, Siwa Oasis, Wadi Digla . Sinai - Romani

Flight: males $(4-8,10)$, females $(6-10)$

Collections: CGR, Naples

\section{Tachytes cameronianus Morice, 1897}

Tachytes cameroniana, Morice, 1897a: 305, ô; holotype $\sigma^{\Uparrow}$ in coll. OUM; loc. typ. Egypt Zeitoun, nr Cairo.

Egyptian synonyms:

Tachytes cameroniana

Tachytes Cameroniana

Morice, 1897a; Storey, 1916.

Tachytes cameronianus

Honoré, 1942;

Pulawski, 1962445 \& 1973; Bohart \& Menke, 1976.

Range: Egypt

Distribution: Gebel el Asfar, Kom Awshim, Maadi, Magadlah, Mansuriya, Zeitoun

Flight: males (5, 7-8), females (6-7)

Collections: CGR, Oxford

\section{Tachytes diodontus Pulawski, 1962}

Tachytes diodontus Pulawski, 1962: 440-441, + ; holotype + in coll. WJP; loc. typ. Egypt - Wadi el Tih.

Egyptian synonyms:

Tachytes diodontus

Pulawski, 1962 \& 1973; Bohart \& Menke, 1976.

Range: Egypt

Distribution: Wadi el Tih (near Cairo)

Flight: females (6)

Collections: WJP

\section{Tachytes maroccanus Pulawski, 1962}

Tachytes maroccanus Pulawski, 1962: 459-460, ð̊; holotype $\widehat{\delta}$ in coll. MNHN; loc. typ. Morocco Tafilalet, Rissani.

Tachytes aegyptiacus sp. n., Pulawski, 1962: 460-461, $q$; holotype $q$ in coll. de Beaumont in MZL; loc. typ. Egypt - Fayoum. Pulawski in Bohart \& Menke, 1976, synonymized aegyptiacus with maroccanus.

Egyptian synonyms:

Tachytes aegyptiacus

Pulawski, 1976; Guichard, 1980: 227.

Notes: Guichard (1980) says "Pulawski (1962) is inclined to associate his female with the males of T. maroccanus from Morocco described by him on the previous page and the two species are synonymized by Bohart \& Menke (1976). However, I associate my two females - if indeed they are T. aegyptiacus - with 11 grey-black males from the same Qurum locality, plus two similar males from Masirah Island. These males obviously are not $T$. maroccanus and have distinctive genitalia not figured in Pulawski's paper of 1962." If Guichard is correct, then the Egyptian species is Tachytes aegyptiacus Pulawski and not T. maroccanus.

Range: Morocco, Egypt, ? Oman (see note above) 
Distribution: Fayyum (as the type was taken by A. Mochi, it is probable that the real name for the type locality is Kom Awshim. According to A. Mochi Jr., his father and he used to refer to that locality as "Fayyum". [personal communication])

Flight : females (10)

Collections: JdeB, MNHNP

pygmaeus species group

\section{Tachytes pygmaeus Kohl, 1888}

Tachytes pygmaeus Kohl, 1888: 134, $\varnothing$ (nec $\lesssim=T$. argyreus (F. Smith)); lectotype $\bigcirc$ in coll. NHMW; loc. typ. Egypt. [Pulawski, 1962]

Egyptian synonyms:

Tachytes pygmaea

Tachytes Frey-Gessneri Kohl

Tachytes pygmaeus
Honoré, 1942.

Honoré, 1942 (partim) (misidentification, per Pulawski, 1962).

Pulawski, 1975.

Range: Morocco, Egypt, India, Sri Lanka

Distribution: Gebel el Asfar, Hawamdieh, Helwan, Kafr Hakim, Kharga Oasis (Dush), Maadi, El Mallah, Tisfa, Zeitoun

Flight: males $(6,8)$, females $(5,7,9)$

Collections: CGR, Vienna

Palarini

Palarus Latreille, 1802-1803

variegatus species group

Palarus dongalensis Klug, 1845

Palarus rufipes Olivier in Spinola, 1839:47 ('Egypt') corrected to dongolensis by de Beaumont 1952:47

Palarus dongalensis Klug, 1945: pl. 47, fig. 1, + ; loc. typ. Sudan - Ambokohl (ZMHU). [de Beaumont, 1949b.]

Palarus decipiens Honoré, 1941b: 197, đ̂,,, ; loc. typ. Egypt - Sokhna on Red Sea Coast [? = Ain Sokhna?] (USNM). [de Beaumont, 1949b.]

Egyptian synonyms:

Palarus decipiens

Honoré, 1942.

Palarus dongalensis

de Beaumont, 1949b; de Beaumont \& BytinskiSalz, 1973; Guichard, 1988b.

\section{Palarus saundersi Morice, 1897}

Palarus saundersi Morice, 1897a: 310-311, pl. 6, figs. 20-22, ô; type in OUM, loc. type. Egypt Koubbeh nr. Cairo.

Egyptian synonyms:

Palarus saundersi

Palarus Saundersi

Morice, 1897a; de Beaumont, 1949b; Guichard, 1988b.

Honoré, 1942.

Palarus spinolae Saussure, 1854 ssp. spinolae (s.s.)

Palarus spinolae Saussure, 1854: 14, fig. 3, $\widehat{\jmath}$, , $;$; holotype from 'Egypt' in MRSN or MHNG. [de Beaumont, 1949b.]

Egyptian synonyms:

Palarus spinolae

Storey, 1916; de Beaumont, 1949b \& 1958d; de Beaumont \& Bytinski-Salz, 1973; Bohart \&

Palarus Spinolae

Menke, 1976, Guichard 1988b

Honoré, 1942. 


\section{histrio species group}

Palarus ambustus Klug, 1845 ssp. ambustus (s.s.)

Palarus ambustus Klug, 1845, pl. 47, fig. 6, ô; holotype ô from Saqqara (ZMHU) [de Beaumont, 1949b.]

Palarus lepidus Honoré, 1941: 200. [de Beaumont, 1949b.]

Egyptian synonyms:

Palarus ambustus Honoré, 1942; de Beaumont, 1949b.

Palarus lepidus Honoré, 1942.

According to Honoré, 1942, Klug described lepidus from Egypt [not mentioned in World Catalogue, and hence must be an error]. Morice, 1911, says he has specimens of lepidus taken by him in Egypt and det. by Kohl.

Range: Morocco, Algeria to Egypt

Distribution: Abu Rawash, Ben Yussef, Bircade, Dahshur, Kafr Hakim, Kerdasa, Mensurie, Saqqara

Flight: de Beaumont, 1949b, cites 3-5 without indicating the sex.

Palarus hastatifrons Turner, 1919 ssp. africanus de Beaumont, 1949

Palarus hastatifrons Turner, 1919: 70, Ô, $\odot$; holotype in BMNH; loc. typ. Palestine [Israel] - Khan Yunnus, 12 miles SW of Gaza. [de Beaumont, 1949b.]

Palarus hastatifrons africanus de Beaumont, 1949: 661, ô, + ; type in MZL., loc.typ.: Morocco - Imiter (sw of Ksar-es-Souk).

Egyptian synonyms: Palarus hastatifrons

de Beaumont, 1966.

Range: Morocco, Algeria, Tunisia, Libya (Tripolitania), Egypt

Distribution: Mersa Matruh

Flight: males (6), females $(6,8)$

Collections: CGR (First record from Egypt)

\section{Palarus histrio Spinola, 1839}

Palarus histrio Spinola, 1839: 474-475, ô,, ; holotype from 'Egypt' in MNHN. [de Beaumont, 1949b]

Egyptian synonyms:

Palarus histrio

Honoré, 1942; de Beaumont, 1949b; de Beaumont

Range: Algeria, Libya (Fezzan), Egypt

Distribution: Cairo (Abbasieh, Zeitoun), Ismailia

Flight: de Beaumont, 1949b, cites 4-6 without indicating the sex.

\section{Palarus laetus Klug, 1845 ssp. laetus (s.s.)}

Palarus laetus Klug, 1845, pl. 47, figs. 4-5, 3 , + ; syntypes from Giza, Egypt (ZMHU) [de Beaumont, 1949b says Egypt - Fayoum]

Larra annulata Walker, 1871: 25, nec Klug, 1845, ơ; syntypes from Sudan coast \& Djibouti (one in BMNH) [de Beaumont, 1949b.]

?Palarus eximius Honoré, 1941: 201, đ̂; holotype đô from Hawamdieh, Egypt (ESEC?) [tentatively synonymised with laetus by de Beaumont, 1949b.]

Egyptian synonyms:

Palarus laetus

Morice, 1911; Honoré, 1942; de Beaumont, 1949b; Pulawski, 1964; de Beaumont \& Bytinski-

Palarus eximius

Salz, 1973; Bohart \& Menke, 1976.

Range: Egypt, Oman

Honoré, 1942; de Beaumont, 1949b.

Distribution: Abu Rawash, Bir el Menayit, Dahshur, Fayyid, Fayyum, Giza,Kerdasa, Kom Awshim, Maadi, $35 \mathrm{~km}$ E of Wadi el Natrun

Flight: males (4-8), females (4-7)

Collections: CGR, WJP 


\section{Palarus parvulus de Beaumont, 1949}

Palarus parvulus de Beaumont, 1949b: 672-673, ô, + ; holotype in MNHN coll. Roth, loc. typ. Ghardaia, Algeria.

Egyptian synonyms: Palarus parvulus

Range: Algeria, Libya (Tripolitania), Egypt

de Beaumont \& Bytinski-Salz, 1973.

Distribution: Kom Awshim

Flight: males (6)

Collections: CGR

Miscophini

Miscophus Jurine, 1807

gallicus species group

\section{Miscophus ctenopus Kohl, 1883}

Miscophus ctenopus Kohl, 1883: 349, §̊, , ; type from Tor, Sinai (NHMW)

Miscophus Manzonii Gribodo, 1884 (May): 386, $\odot$; type in MCSNG; loc. typ. Yemen - Sheikh Osman. [Guiglia, 1939.]

Miscophus rubriventris Honoré, 1944b: 141-142, o; type in ?USNM; loc. typ. Egypt - Maadi. Preoccupied by Miscophus rubriventris Ferton, 1896.

Miscophus honorei Balthasar, 1954, nom. nov. for M. rubriventris Honoré [de Andrade, 1954.]

Egyptian synonyms:

Miscophus Manzonii

Miscophus manzonii

Miscophus ctenopus

Honoré, 1942 \& 1944b.

de Beaumont, 1950c; Sayed et al, 1964.

de Andrade, 1954; Pulawski, 1964; de Beaumont, 1966; Osborn \& Krombein, 1969. The record of Osborne \& Krombein, 1969, is from Gebel

'Uweinat, but from the Sudanese part.

See note under M. sericeus on the earlier use of this name. Records of specimens of either species determined before de Andrade's 1954 paper are suspect.

Range: Spanish Sahara, Morocco, Algeria, Libya (Tripolitania, Cyrenaica), Egypt, Sudan (Gebel 'Uweinat), Saudi Arabia

Distribution: Abu Rawash, Abu Sir, Bekeihla, Cairo, Dahshur, Giza, Giza (Pyramids), Kerdasa, Kom Awshim, Mersa Matruh. Sinai - St. Catherine's, Tor

Flight: males (2-7, 10-11), females (4-5, 10-12)

Collections: CGR, WJP

\section{Miscophus dispersus de Andrade, 1954}

Miscophus honoréi de Andrade, 1954: 44 (nec Balthasar = M. ctenopus Kohl).

Miscophus dispersus de Andrade, 1954: 85-86,, ; nom. nov. for Miscophus honoréi, holotype in coll. IEEM; loc. typ. Spanish Sahara - Saguia el Hamra, El Ayun.

Egyptian synonyms:

Miscophus dispersus $\quad$ de Andrade, 1954; de Beaumont, 1958d;

Pulawski, 1964.

Range: Spanish Sahara, Algeria, Egypt, Sudan (Wadi Halfa)

Distribution: Giza (Pyramids), Kom Awshim, Kom Ombo

Flight: males (2-4), females $(2,5,10)$

Collections: CGR, WJP

\section{Miscophus flavopictus Pulawski, 1964}

Miscophus flavopictus Pulawski, 1964: 126-128, đ̊, + ; holotype $\odot$ in WJP; loc. typ. Egypt - Sinai, St. Catherine's Monastery.

Egyptian synonyms:

Miscophus flavopictus

Bohart \& Menke, 1976. 
Range: Egypt (Sinai)

Distribution: Sinai - St. Catherine's

Flight: males (4), females (4)

Collections: WJP

\section{Miscophus funebris Honoré, 1944}

Miscophus funebris Honoré, 1944b: 132-133, o; holotype in USNM; loc. typ. Egypt - Hawamdieh. Egyptian synonyms:

Miscophus funebris Pulawski, 1964; Bohart \& Menke, 1976.

Range: Egypt

Distribution: Gebel el Asfar, Hawamdieh, Kom Ombo

Flight: males $(2,7)$, females $(1-2,11)$

Collections: CGR, WJP

\section{Miscophus imitans Giner Marí, 1945}

Miscophus imitans Giner Marí, 1945: 240, đ̃,o; holotype in IEE; loc.typ. Bu Kerch (Western Sahara)

Egyptian synonyms:

Miscophus imitans

de Andrade, 1954; Pulawski, 1964; de Beaumont \& Bytinski-Salz, 1973.

Range: Spanish Sahara, Morocco, Algeria, Libya (Tripolitania, Fezzan), Egypt, Israel (Negev)

Distribution: Abu Rawash, Abydos, Baharia Oasis, Edfu, Fayyum, Gebel el Asfar, Giza, Giza (Pyramids), Kerdasa, Kom Awshim, Luxor, Maadi, Saqqara, Tahrir, Tell el Amarna, Wadi Digla, Wadi Hoff. Sinai - 26km w of el Arish, $10 \mathrm{~km}$ e of El Arish

Flight: males $(1-5,8,11)$, females $(1,3-5,10-12)$

Collections: CGR, WJP

\section{Miscophus mochii Arnold, 1940}

Miscophus Mochii Arnold, 1940: 130, fig.22, +; holotype $q$ in NMSR; loc. typ. Egypt - Wadi Digla.

Miscophus pretiosus brunnescens Honoré, 1944b, §,,, ; holotype $q$, from Egypt - Wadi Digla (USNM).

Egyptian synonyms:

Miscophus mochii

Arnold, 1940; de Andrade, 1954; Pulawski, 1964;

Miscophus pretiosus brunnescens de Beaumont \& Bytinski-Salz, 1973.

Honoré, 1944b.

Range: Morocco, Egypt, Israel (Negev)

Distribution: Maadi, Shaluf, Tell el Amarna, Wadi Digla, Wadi Hoff. Sinai - Wadi Mitla

Flight: males $(3,5)$, females $(3,6)$

Collections: WJP

\section{Miscophus nigripes Honoré, 1944}

Miscophus Manzonii var nigripes Honoré, 1944b: 140, nec p.142; lectoholotype selected by de Andrade, 1954. in coll Alfieri (USNM); loc. typ. Egypt.

Miscophus rubriventris var. nigripes Honoré, 1944b: 142 nec p.140, $q$; holotype $q$ in coll. Alfieri (USNM); loc. typ. Egypt - Abu Rawash. Synonymised by de Andrade, 1954: 86

Miscophus lotus de Andrade, 1954: 73-76, Ô, o; holotype in MZCP; loc. typ. Egypt - Cairo. Synonymized by de Andrade 1954: 86 (Dollfuss 1989: 10).

Egyptian synonyms:

Miscophus Manzonii var nigripes Miscophus rubriventris var. nigripes Miscophus nigripes

Range: Egypt, Sudan (Gebel 'Uweinat)
Honoré, 1944b.

Honoré, 1944b.

Pulawski, 1964; Osborn \& Krombein, 1969; de Beaumont \& Bytinski-Salz, 1973; Bohart \& Menke, 1976. The record of Osborne \& Krombein, 1969, is from Gebel 'Uweinat, but from the Sudanese part. 
Distribution: Abu Rawash, Abydos, Cairo, Edfu, Fayyum (5km N of Dimei, Hawarah), Gebel el Asfar, Giza, Helwan, Kerdasa, Kom Awshim, Luxor, Saqqara, Tell el Amarna, Wadi Digla, Wadi Hoff, Wadi Rishrash, Sinai

Flight: males (1-6, 10-12), females (1-5, 8, 10-12)

Collections: CGR, WJP

\section{Miscophus obscuritarsis Pulawski, 1964}

Miscophus obscuritarsis Pulawski, 1964: 120-122, $\widehat{\jmath}$,, ; holotype in WJP; loc. typ. Egypt - Maadi. Egyptian synonyms:

Range: Egypt

Distribution: Giza, Kom Awshim, Maadi

Flight: males (4), females (4)

Collections: CGR, WJP

\section{Miscophus papyrus de Andrade, 1954}

Miscophus papyrus de Andrade, 1954: 42-44, + ; holotype $q$ in ZMHU; loc. typ. Egypt - Cairo. Egyptian synonyms: Miscophus papyrus

Range: Algeria, Libya (Tripolitania), Egypt de Beaumont, 1958d; Pulawski, 1964.

Distribution: Abu Rawash, Cairo (Abbassieh), Edfu, Fayyid, Gebel el Asfar, Giza (Pyramids), Kerdasa, Kom Awshim, Kom Ombo, Luxor, Maadi, Siala

Flight: males 1-4, 7, 10-11), females (3-5, 8, 10-11)

Collections: CGR, WJP

\section{Miscophus sericeus Radoszkowski, 1876}

Miscophus sericeus Radoszkowski, 1876: 134. Holotype or syntype from 'Egypt' (ZMJU)

Egyptian synonyms:

Miscophus ctenopus

Storey, 1916; Honoré, 1942 \& 1944b.

Radoszkowski's species was not known to the earlier hymenopterists in Egypt who misused ctenopus Kohl for this species. Without seeing the specimens in the Ministry of Agriculture, Cairo, collection which were being listed by Storey, it is not possible to be sure that they were sericeus, but I have made that assumption since Honoré, 1942 \& 1942b, was presumably following the lead of his predecessors. Unfortunately, Storey did not list any manzonii which would have confirmed this.

Miscophus sericeus

de Andrade, 1954; Pulawski, 1964.

Range: Mauritania, Morocco, Libya (Tripolitania, Cyrenaica), Egypt, Sudan, sw USSR

Distribution: Abu Rawash, Baharia Oasis, Cairo (environs), Dahshur, Fayyid, Fayyum ( $3 \mathrm{~km} \mathrm{~N} \mathrm{of}$ Qasr Qarun), Kafr Farouk, Kerdasa, Kom Awshim, Tell el Amarna, Wadi Digla, Wadi el Natrun, Wadi er Rayan

Flight: males (3-6), females (3-4, 6-7, 9)

Collections: CGR, WJP

\section{Miscophus similis F. Morawitz, 1897}

Miscophus similis F. Morawitz, 1897: 149, , ; holotype or syntypes from Transcaspia (ZIN)

Egyptian synonyms:

Miscophus similis

Range: Egypt (Sinai), sw USSR

Distribution: Sinai - St. Catherine's

Flight: females (4)

Collections: WJP
Pulawski, 1964; de Beaumont \& Bytinski-Salz, 1973. 


\section{bicolor species group}

\section{Miscophus aegyptius Morice, 1897}

Miscophus aegyptius Morice, 1897a: 315-316,, ; holotype $\odot$ in OUM; loc. typ. Egypt - Abbasieh.

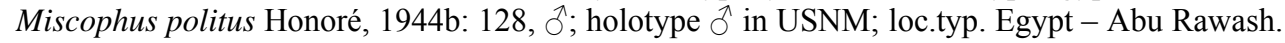
Synonymised by de Andrade 1960: 102

Egyptian synonyms:

Miscophus aegyptius

Morice, 1897a; Honoré, 1944b; de Andrade, 1960; Miscophus aegyptium (sic) Pulawski, 1964; Bohart \& Menke, 1976. Miscophus politus Honoré, 1942. Honoré, 1944b.

Range: Egypt to Syria

Distribution: Abu Rawash, Cairo (Abbassieh), Edfu, Gebel el Asfar, Giza, Kerdasa, Kom Awshim, Luxor, Saqqara, Tel el Amarna, Wadi Digla, Wadi Rishrash

Flight: males (5), females (4-5)

Collections: CGR, WJP

\section{Miscophus aenigma Honoré, 1944}

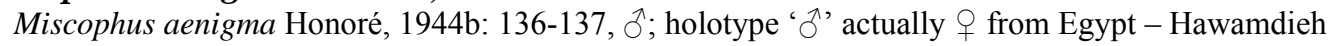
(USNM). [de Andrade, 1960]

Egyptian synonyms:

Miscophus aenigma

de Andrade, 1960; Pulawski, 1964; Bohart \&

Range: Egypt

Distribution: Abydos, Cairo (Hawamdieh), Fayyid, Giza, Kom Awshim, Kom Ombo

Flight: males $(4-5,7,10)$, females $(2-3,5)$

Collections: CGR, WJP

\section{Miscophus affinis Pulawski, 1964}

Miscophus affinis Pulawski, 1964: 116-119, Oૈ,, ; holotype in WJP; loc. typ. Egypt - Abu Rawash.

Egyptian synonyms:

Miscophus affinis

Bohart \& Menke, 1976.

Range: Egypt, Oman

Distribution: Abu Rawash, Giza, Kerdasa. Sinai - 10km E of El Arish

Flight: males (4), females $(5,8,11)$

Collections: CGR, WJP

\section{Miscophus bicolor Jurine, 1807}

Miscophus bicolor Jurine, 1807: pl. 11, gen 25., $\delta^{\lambda}$; holotype $\delta^{\lambda}$ in coll. Jurine in MHNG. [de Andrade, 1960.]

Egyptian synonyms: Miscophus bicolor ssp.

Pulawski, 1964.

Range: If Pulawski's view that the Egyptian specimens form a separate subspecies is correct, then the range is Egypt. If, however, they are merely a variety of Miscophus bicolor bicolor Jurine then the range is: Europe (Poland), Egypt, Crete, Turkey

Distribution: Abu Rawash

Flight: females (11)

Collections: WJP

\section{Miscophus clypearis Honoré, 1944}

Miscophus clypearis Honoré, 1944b: 127-129, ô; holotype from Egypt - Dahschour (USNM).

Egyptian synonyms:

Miscophus clypearis

Range: Egypt

Distribution: Abu Rawash, Dahshur

Flight: males (4), females (10-11)

Collections: WJP de Andrade, 1960; Pulawski, 1964; de Beaumont, 1968a; Bohart \& Menke, 1976. 
Miscophus inconspicuus de Andrade, 1960

Miscophus inconspicuus de Andrade, 1960: 119-121, ठ̊, , ; holotype ${ }^{\wedge}$ in NHMW; loc. typ. Egypt Luxor.

Egyptian synonyms:

Miscophus inconspicuus $\quad$ de Andrade, 1960; Bohart \& Menke, 1976.

Range: Egypt

Distribution: Luxor

\section{Miscophus mimeticus Honoré, 1944}

Miscophus mimeticus Honoré, 1944b: 133-134, đ̂, + ; syntypes from Egypt - Dahschour \& Kafr Farouk (USNM). According to de Andrade, 1960, the holotype is in coll. Alfieri.

Egyptian synonyms:

Miscophus mimeticus de Andrade, 1960; Pulawski, 1964; Bohart \&

Range: Egypt, sw USSR Menke, 1976.

Distribution: Abu Rawash, Abydos, Dahshur, Gebel el Asfar, Giza, Hawamdieh, Kafr Farouk, Kerdasa, Kom Awshim, Kom Ombo, Luxor, Maadi, Mersa Matruh, Tahrir, Wadi Rishrash

Flight: males $(2-5,8,10-12)$, females (3-4, 6, 11-12)

Collections: CGR, WJP

\section{Miscophus pharaonis Arnold, 1940}

Miscophus pharaonis Arnold, 1940: 131-132, figs. 23, 23a \& b, $q$; holotype + in SAM; loc. typ. Egypt - Fayum.

Miscophus frater Honoré, 1944b: 135-136, ô; holotype ô in USNM; loc. typ. Egypt - Km 53, Fayoum road (= Kom Awshim). Synonymised by de Andrade 1960: 128

Egyptian synonyms:

Miscophus pharaonis Arnold, 1940; de Andrade, 1960; Pulawski, 1964.

Miscophus frater

Honoré, 1944b.

Range: Libya, Egypt, Israel

Distribution: Edfu, Fayyum (Hawarah), Kom Awshim, Luxor, Wadi el Natrun

Flight: males (1-3, 10-12), females $(2-4,10,12)$

Collections: CGR, WJP

\section{Miscophus pseudomimeticus de Andrade, 1960}

Miscophus pseudomimeticus de Andrade, 1960: 81-82, + ; holotype + in RMNH; loc. typ. Tunisia - Tozeur.

Egyptian synonyms:

In coll CGR there is a $q$ from Wadi el Natrun, a new record for the Egyptian fauna.

Range: Canary Is., Algeria, Egypt, Israel

Distribution: Wadi el Natrun

Flight: females (11)

Collections: CGR

handlirschi species group

\section{Miscophus alfierii Honoré, 1944}

Miscophus Alfierii nov. spec., Honoré, 1944b: 125-127, ô, ૧; syntypes from Egypt - Wadi Hof \& Abu Rawash (USNM). According to de Andrade, 1956, who designated it, the lectoholotype is in coll. Alfieri.

Egyptian synonyms:

Miscophus Nicolaï Ferton, 1896

Honoré, 1942. Honoré recognized his mistaken determination and described alfierii in his 1944b paper.

Miscophus alfierii

Verhoeff, 1955; de Andrade, 1956; de Beaumont, 1960a \& 1966; de Beaumont \& Bytinski-Salz, 1973; Bohart \& Menke, 1976.

Range: Libya (Tripolitania, Cyrenaica), Egypt, Sinai, Israel 
Distribution: Abu Rawash, Alexandria (Abukir, Ikingi, Mariut, Mex), Port Said, Tahrir, Wadi Digla, Wadi Hoff. Sinai - $10 \mathrm{~km}$ e of El Arish

Flight: males $(4-5,8)$, females (4-5)

Collections: CGR

niloticus species group

\section{Miscophus niloticus Honoré, 1944}

Miscophus niloticus Honoré, 1944b: 131-132, q; holotype $q$ from Egypt - Hawamdieh (USNM). According to de Andrade, 1960, the holotype is in coll. Alfieri.

Egyptian synonyms:

Miscophus niloticus

Range: Egypt

Distribution: Hawamdieh

Flight: females (6)

unknown species group

\section{Miscophus collaris Honoré, 1944}

Miscophus collaris Honoré, 1944b: 143; type lost before full description, but after being keyed; loc. typ. Egypt - Wadi Digla.

Egyptian synonyms:

Miscophus collaris $\quad$ Bohart \& Menke, 1976.

Range: Egypt

Distribution: Wadi Digla

Nitela Latreille, 1809

(Nitela) (s.s.)

\section{Nitela (Nitela) mochii Arnold, 1940}

Nitela Mochii Arnold, 1940: 129, fig. 21, $\uparrow$; holotype $\odot$ in NMSR; loc. typ. Egypt - Wadi Digla. Egyptian synonyms:

Nitela Mochii

Nitela mochii

Range: Egypt de Andrade, 1960; Bohart \& Menke, 1976.

\section{Solierella Spinola, 1851}

\section{Solierella aegyptia Kohl, 1898}

Solierella aegyptia Kohl, 1898: 352, o; type in NHMW; loc.typ.: Lower Egypt Egyptian synonyms:

Solierella aegyptia

Solierella aegyptiaca (lapsus)

Range: Egypt

Distribution: Aswan, Baharia Oasis, Gebel el Asfar, Kom Awshim

Flight: males (2-5), females (2)

Collections: CGR, WJP

\section{Solierella ?compedita (Piccioli, 1869) ssp. compedita (s.s.)}

Solierella compedita Piccioli, 1869: 283, +; type despitory unknown, loc.typ.: Italy - Fiesole (near Florence)

Egyptian synonyms:

Soleriella compedita (Piccioli) de Beaumont, 1964c: 55 
In coll Roche, but the determination is not quite certain. If it is correct then it constitutes the first record of this species from Egypt. De Beaumont \& Bytinski-Salz, 1973, state that its distribution is "C. Europe, Circummediterranean (excl. Libya and Egypt)".

Range: Portugal, Spain, France, Switzerland, Italy, Austria, Czechoslovakia, Hungary, Bulgaria, Greece, Rhodes, USSR (Crimea), Morocco, Algeria, ? Egypt, Jordan, Syria

Distribution: Giza (Pyramids)

Flight: males (6)

Collections: CGR (First record from Egypt)

\section{Solierella dispar Pulawski, 1964}

Solierella dispar Pulawski, 1964: 139-141, đ̂,, ; holotype in WJP; loc. typ. Egypt - Abu Rawash. Egyptian synonyms: Solierella dispar de Beaumont, 1968a; Bohart \& Menke, 1976.

Range: Egypt, Canary Is.

Distribution: Abu Rawash, Kerdasa, Kom Awshim, Saqqara

Flight: males (4-5), females (4-5)

Collections: CGR, WJP

\section{Solierella longicornis Pulawski, 1964}

Solierella longicornis Pulawski, 1964: 134-136, §; holotype $\curvearrowright$ in WJP; loc. typ. Egypt - Kom Oshim.

Egyptian synonyms:

Solierella longicornis Bohart \& Menke, 1976.

Range: Egypt

Distribution: Kom Awshim

Flight: males (4)

Collections: WJP

\section{Solierella nigridorsum Pulawski, 1964}

Solierella nigridorsum Pulawski, 1964: 136-137,, ; holotype $q$ in WJP; loc. typ. Egypt - Giza. Egyptian synonyms: Solierella nigridorsum

Bohart \& Menke, 1976.

Range: Egypt

Distribution: Fayyid, Giza, Kerdasa, Kom Awshim, Maadi

Flight: males (4-5), females $(4-5,7)$

Collections: CGR, WJP

\section{Solierella nitraria Pulawski, 1967}

Solierella nitraria Pulawski, 1967: 65, ô, of; loc.typ. Bir Hooker, Wadi Natrun, Egypt (USNM)

Egyptian synonyms: Solierella nitraria Bohart \& Menke, 1976.

Range: N.Africa, Egypt

\section{Solierella pectinata Pulawski, 1964}

Solierella pectinata Pulawski, 1964: 137-139, + ; holotype $\odot$ in WJP; loc. typ. Egypt - Saqqara.

Egyptian synonyms: Solierella pectinata de Beaumont, 1968a; Bohart \& Menke, 1976.

Range: Egypt, Canary Is.

Distribution: Kerdasa, Saqqara

Flight: females $(3,5)$

Collections: CGR, WJP

\section{Solierella sp.aff. verhoeffi de Beaumont}

Egyptian synonyms:

In coll Roche there is an unidentified specimen which seem closely related to, but different from verhoeffi.

Range: Egypt 
Distribution: Wadi Ramila

Flight: males (5)

Collections: CGR

Trypoxylini

Pison Jurine, in Spinola, 1808

\section{Pison carinatum Turner, 1917}

Pison xanthopus R.Turner, 1916, nec Brullé, 1833. ô, q; type in BMNH; loc.typ.: Ghana Ashanti.

Pison carinatum R.Turner, 1917: 111, Ô, + , nom. nov. for P. xanthopus Turner nec Brullé. Syntypes from Ghana \& Uganda (BMNH), Maadi, Egypt (PPDD) [Arnold, 1924.]

Egyptian synonyms:

Pison xanthopus Brullé Storey, 1916; Arnold, 1924; Honoré, 1942.

Pison carinatum

Arnold, 1924; de Beaumont 1961c, de Beaumont \& Bytinski-Salz, 1973; Bohart \& Menke, 1976.

It is strange that xanthopus was stated to be a "misidentification of a West African species" by Turner in 1916, but Storey had already used it in 1914 (published 1916).

Range: Central Africa, Ghana, Egypt, Cyprus, Oman

Distribution: Cairo (Barrages, Zamalek, Maadi)

Flight: females (7-8)

Collections: CGR [\& PPDD according to World Catalogue]

Trypoxylon Latreille, 1796

Trypoxylon aegyptium Kohl, 1906

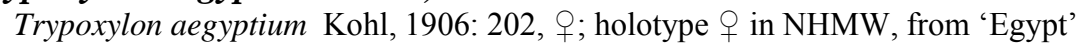
Egyptian synonyms:

Trypoxylon aegyptium

Honoré, 1942; Pulawski, 1964; Osborn \& Krombein, 1969; Krombein, 1969; de Beaumont Trypoxylon aegyptiacum (lapsus) \& Bytinski-Salz, 1973; Bohart \& Menke, 1976. de Beaumont, 1958d.

Range: Mauritania, Algeria, Libya (Tripolitania), Egypt

Distribution: Dakhla Oasis (Tineida), Gebel el Asfar, Kom Awshim, Luxor, el Minia, Saqqara

Flight: males $(2,4-6,8,10)$, females $(5,10)$

Collections: CGR, WJP

\section{Trypoxylon albipes F. Smith, 1856}

Trypoxylon albipes F. Smith, 1856: 377, + ; lectotype $\odot$ in OXUM, from 'Albania'

Egyptian synonyms:

Trypoxylon albipes Honoré, 1942 [Antropov, 1995]

Range: Spain, France, Cyprus, Albania, Greece, Turkey, Syria, Azerbaijan, Uzbekhistan, Tajikistan, Pakistan, Armenia, Algeria, Egypt, Turkmenistan, Israel, Italy

\section{Trypoxylon attenuatum F. Smith, 1851 ssp. attenuatum (s.s.)}

Trypoxylon attenuatum F.Smith, 1851: 120, of lectotype ${ }^{\lambda}$ in OXUM, typ.loc. Bristol (UK)

Egyptian synonyms:

Trypoxylon attenuatum

Storey, 1914.

Range: Europe, Asia (Canary Isl, Egypt, Crete, Turkey)

Distribution: Cairo (Zamalek), Gebel el Asfar

Flight: males (3), females (3, 6-7, 9)

Collections: CGR (First record from Egypt)

\section{Trypoxylon scutatum Chevrier, 1867}

Trypoxylon scutatum Chevrier, 1867: 231, + ; holotype + in MHNG, loc.typ. Genève, Switzerland Egyptian synonyms: 
Trypoxylon scutatum

Range: S Europe, Algeria, Libya (Cyrenaica), Egypt, Crete, Turkey

Distribution: Gebel el Asfar

Flight: males (8)

Collections: CGR (First record from Egypt)

\section{Oxybelini}

Belomicrus A. Costa, 1871

\section{Belomicrus dimorpha Guichard, 1991}

[ Editor's note: listed in Roche (2007) as a new record to Egypt, with specimens in CGR, but not included here ]

\section{Belomicrus mirificus Kohl, 1905}

Belomicrus (Oxybelomorpha) mirificus Kohl, 1905: 225,, ; holotype $\odot$ in coll. NHMW; loc. typ. Ethiopia. [Kohl, 1923; Arnold, 1927; Guichard, 1991.]

Egyptian synonyms:

Belomicrus (Oxybelomorpha) mirificus $\quad$ Honoré, 1942.

Belomicrus mirificus $\quad$ Pulawski, 1964; Bohart \& Menke, 1976;

Range: Ethiopia, Egypt

Guichard, 1991.

Distribution: Aswan

Flight: males (2), females (2)

Collections: WJP

\section{Belomicrus odontophorus (Kohl, 1892)}

Oxybelus odontophorus Kohl, 1892: 205, + ; holotype $q$ in NHMW; loc.typ. Arax River Valley (Armenia or Azerbaijan)

Egyptian synonyms:

In coll CGR there is a $\delta$ from Ain Sokhna road, $50-85 \mathrm{~km}$ E of Maadi. This the first record of this species from Egypt.

\section{Belomicrus pharaonum Pulawski, 1964}

Belomicrus pharaonum Pulawski, 1964: 151-153, Õ, holotype in WJP, loc. typ. Egypt - Abu Rawash,.

Egyptian synonyms:

Belomicrus pharaonum Pulawski, 1964.

Range: Egypt

Distribution: Abu Rawash

Flight: males (3-4)

Collections: WJP

Oxybelomorpha Brauns in Kohl, 1897

Oxybelomorpha waterstonii Kohl, 1923

Belomicrus Waterstoni Kohl, 1923: 263-265, + ; holotype $\odot$ in coll. BMNH; loc. typ. Palestine nr. Jerisheh.

Egyptian synonyms:

Belomicrus waterstoni

Guichard, 1991.

Range: Israel, Egypt

Distribution: Gebel Elba 
Oxybelus Latreille, 1796

lamellatus species group

Oxybelus diphyllus (A. Costa, 1882) ssp. pharao Kohl, 1884

Alepidaspis diphyllus Costa, 1882: 35, o; holotype + from Sardegna, Italy (MZUN). [Guichard, 1990.]

Oxybelus pharao Kohl, 1884: 105, + ; syntype $\odot$ in coll. NHMW; loc.typ.: Cairo. Reduced to a ssp. by de Beaumont, 1950: 413

Egyptian synonyms:

Oxybelus pharao Honoré, 1942.

Oxybelus diphyllus pharao de Beaumont, 1950a \& 1958d; Pulawski, 1964.

Range: Morocco, Chad (Tibesti), Egypt. Note: de Beaumont (1958d) does not say that pharao is the N African subspecies, only that it is the Egyptian one. Thus the Moroccan and Chadian specimens may not be of this subspecies.

Distribution: Abydos, Cairo, (Hawamdieh per Honoré, 1942), El Minia (?), Saqqara (?), (Tura per Honoré 1942)

Flight: males $(3,9$ ?, 10)

Collections: CGR (?), WJP. Note: the two males in Coll. CGR do not have a definite determination. Hence the query marks in Distribution and Flight.

Oxybelus lamellatus Olivier, 1811 ssp. lamellatus (s.s.)

Oxybelus lamellatus Olivier, 1811: 595; syntypes from 'Egypt' and Baghdad, Iraq (lost). [Krombein, 1982; Guichard, 1990.]

Oxybelus Savignyi, Spinola, 1839: 483, ô; syntypes from Egypt (MRSN)

Egyptian synonyms:

Oxybelus lamellatus

Morice, 1911; de Beaumont, 1950a; Pulawski, 1964; de Beaumont, 1966.

Oxybelus (Notoglossa) lamellatus

Honoré, 1942.

Range: Morocco, Algeria, Libya (Tripolitania, Cyrenaica), Egypt, Palestine, Cyprus, Turkey, Oman, W India

Distribution: Abu Rawash, Abydos, $25 \mathrm{~km} \mathrm{~S}$ of Ain Sokhna, $60 \mathrm{~km} \mathrm{~S}$ of Alexandria (desert road to Cairo), Baharia Oasis, Dakhla Oasis (Al Qasr), Fayyum (Hawarah), Gebel el Asfar, Giza, Helwan, Kerdasa, Kom Awshim, Maadi, Manqabad, Mersa Matruh, el Minia, 10th Ramadan City, Wadi el Natrun, $35 \mathrm{~km}$ E of Wadi el Natrun . Sinai - 26km W of El Arish, $20 \mathrm{~km} \mathrm{E} \mathrm{of} \mathrm{El}$ Arish, Hamamat Faraoun, Wadi Feiran

Flight: males (3-11), females $(3-4,7-9,11)$

Collections: CGR, WJP

\section{Oxybelus phyllophorus Kohl, 1898}

Oxybelus phyllophorus Kohl, 1898: 355, Ô, o; syntypes in NHMW \& TMB; loc.typ. Cairo and Adelen-Inseln opposite Dahshur.

Egyptian synonyms: Oxybelus (Notoglossa) phyllophorus Honoré, 1942.

Oxybelus phyllophorus de Beaumont, 1958d; Pulawski, 1964; Bohart \&

Range: Algeria, Chad (Tibesti), Egypt

Distribution: Aswan, Cairo, Maadi, el Minia

Flight: males $(2-3,10)$, females (4)

Collections: CGR, WJP

other species groups

Oxybelus aurantiacus Mocsáry, 1883

Oxybelus aurantiacus Mocsáry, 1883: 48, + ; holotype + lost in TMB; loc.typ. Budapest, Hungary. [Pulawski, 1965b]

Egyptian synonyms: 
Oxybelus aurantiacus

Pulawski, 1964.

Range: S Europe, Morocco, Algeria, Egypt, Turkey, sw USSR

Distribution: Abu Rawash, Abydos, Giza, Kom Awshim

Flight: males (3-4), females (3-5)

Collections: WJP

\section{Oxybelus collaris Kohl 1884}

Oxybelus collaris Kohl, 1884: 107, + ; holotype $q$ in coll. NHMW; loc.typ. "Arabia felix: Tor", probably Tor Sinai. [Guichard, 1990.]

Egyptian synonyms:

Oxybelus collaris

Honoré, 1942; Guichard, 1990

Range: Arabian peninsula

\section{Oxybelus continuus Dahlbom, 1845}

Oxybelus continuus Dahlbom, 1845: 513, đ̊; holotype đึ in MZLU; loc.typ. 'Egypt'

Egyptian synonyms:

Oxybelus continuus

Bohart \& Menke, 1976.

Range: Egypt

\section{Oxybelus fischeri Spinola, 1939 ssp. fischeri (s.s.)}

Oxybelus Fischeri, N. Sp., Spinola, 1839: 484, , ; holotype $q$ from 'Egypt' (?MRSN)

Oxybelus africanus Kohl, 1884: 106, + ; holotype + from Cairo (NHMW, TMB). Synonymised by Verhoeff, 1948: 204

Egyptian synonyms:

Oxybelus africanus $\quad$ Honoré, 1942.

Oxybelus fischeri

Verhoeff, 1948; de Beaumont, 1958d; Pulawski, 1964; Bohart \& Menke, 1976.

Range: Morocco, Algeria, Libya (Tripolitania, Fezzan), Egypt

Distribution: Abu Rawash, Cairo, Dahshur, Gebel el Asfar, Giza, Giza (Pyramids), Helwan, Kerdasa, Kom Awshim, Maadi, Saqqara, Wadi Digla, Wadi el Natrun, 35km E of Wadi el Natrun. Sinai $-65 \mathrm{~km}$ W of El Arish, $30 \mathrm{~km} \mathrm{~W} \mathrm{of} \mathrm{El} \mathrm{Arish}$

Flight: males (3-6, 10-11), females (3-5)

Collections: CGR, WJP

\section{Oxybelus guichardi de Beaumont, 1950}

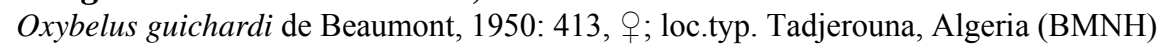

Egyptian synonyms:

Oxybelus guichardi de Beaumont, 1953

\section{Oxybelus palmetorum de Beaumont, 1950}

Oxybelus palmetorum de Beaumont, 1950a: 416-417, क; type in coll. BMNH; loc. typ. Algeria Tadjemout,.

Egyptian synonyms:

Oxybelus palmetorum

de Beaumont, 1958d; Pulawski, 1964; Bohart \& Menke, 1976.

Range: Mauritania, Algeria, Tunisia, Libya (Tripolitania), Egypt

Distribution: Abu Rawash, Aswan, Giza, Kom Awshim

Flight: males $(2,11)$, females (10)

Collections: CGR, WJP

\section{Oxybelus subspinosus Klug, 1835}

Oxybelus subspinosa Klug in Waltl 1835:98, $q$; syntype $\subsetneq$ from Andalusia, Spain (ZMHU)

Egyptian synonyms:
Oxybelus subspinosus
Honoré, 1942,

Range: S Europe, Algeria, Libya (Cyrenaica), Turkey 
Pseudomicroides Antropov, 2001

Pseudomicroides santschii (Schulthess, 1925)

Oxybelus santschii Schulthess, 1925: 187, +; holotype $\odot$ in von Schulthess coll in ETHZ; typ.loc. Hammamet, Tunisia.

Egyptian synonyms:

Belomicrus (Belomicroides) santschii Honoré, 1942.

Range: Tunisia

Pseudomicroides or Belomicroides sp., not santschii, ? sp. nov.

Egyptian synonyms:

In coll CGR a 9 from Wadi Digla.

Crabronini

Crossocerus Lepeletier \& Brullé, 1835

Crossocerus adhaesus (Kohl, 1915)

Crabro (Crossocerus: Crossocerus) adhaesus Kohl, 1915: 261-2, ô; holotype $\widehat{o}$ in coll BMNH; loc. typ. sw Iran.

Egyptian synonyms:

There is a series of $\hat{o} \widehat{d} \&$ 우우 in coll CGR from Wadi Digla. This the first record of the species from Egypt.

Dasyproctus Lepeletier \& Brullé, 1835

\section{Dasyproctus arabs (Kohl, 1894)}

Crabro (Dasyproctus) arabs Kohl, 1894: 283, + ; holotype $q$ from Tor, Sinai (NHMW). [Kohl, 1915.]

Egyptian synonyms:

Crabro (Dasyproctus) arabs $\quad$ Kohl, 1915; Honoré, 1942; de Beaumont, 1952;

Dasyproctus arabs

Pulawski, 1964.

Bohart \& Menke, 1976.

Range: Algeria, Egypt, Somalia, Uganda, Israel, Syria, Iran, Pakistan

Distribution: Cairo, Sinai - Tor

Flight: males (10)

Collections: WJP

Ectemnius Dahlbom, 1845

Ectemnius confinis (Walker, 1871)

Crabro confinis Walker, 1871: 27, $\widehat{\partial}, \circ$; syntypes from Cairo (lost); neotype $\hat{O}^{\lambda}$ from 'Egypt' (MNHN) [Kohl, 1915.]

Ectemnius laevigatus, Oे, Destefani, 1884: 220 [Kohl, 1915.]

Egyptian synonyms:

Crabro (Solenius) laevigatus

Crabro (Subgen.?) confinis

Kohl, 1915.

Crabro confinis

Kohl, 1915.

Crabro (Solenius) confinis

Storey, 1916.

Crabro (Ectemnius) laevigatus

Honoré, 1942.

Pulawski, 1964.

Range: Egypt, Crete, Turkey, sw USSR, n India

Distribution: Gebel el Asfar, Kabrit, Kom Awshim, Qaha

Flight: males (2-7), females (4, 6-7) 
Collections: CGR, WJP

\section{Ectemnius continuus (Fabricius, 1804)}

Crabro continuus, Fabricius, 1804: 312; loc.typ. Tanger, Morocco (ZMK) [Kohl, 1915.]

Crabro impressus, F. Smith, 1856: 401. [Kohl, 1915.]

Crabro granulatus, ô, Walker, 1871: 26; type from Cairo (lost); neotype $\widehat{\jmath}$ from Cairo (CAS). [Kohl, 1915.]

Egyptian synonyms:

Crabro (Crabro, Solenius) impressus Kohl, 1915.

Crabro (Subgen.?) granulatus Kohl, 1915, Honoré, 1942.

Crabro (Crabro, Solenius) vagus Linnaeus, 1758 Kohl, 1915.

Crabro (Solenius) vagus Lepeletier, 1834 (sic) Honoré, 1942, fide Spinola. The Linnean species is in the genus Mellinus. Kohl's usage is covered by Bohart \& Menke, 1976, as "vagus of authors, not Linnaeus". Presumably Lepeletier is one of Crabro (Ectemnius) continuus the authors.

Range: Morocco, Algeria, Egypt, Crete, Turkey

Distribution: Cairo

Flight: males (11)

Collections: WJP

\section{Ectemnius hypsae (De Stefani, 1894)}

Crabro Hypsae Destefani, 1884: 217, §,o; types from Silicia, Italy (depository unknown). [Kohl, 1915.]

\section{Egyptian synonyms:}

Crabro (Crabro, Solenius) hypsae Kohl, 1915.

Entomognathus Dahlbom, 1844

\section{Entomognathus brevis (Vander Linden, 1829)}

Crabro brevis, Vander Linden, 1829: 70, ठ̊, , ; loc.typ. Bruxelles,Belgium \& Bologna, Italy (ISNB). [Kohl, 1915.]

Egyptian synonyms:

Crabro (Entomognathus) brevis var. Kohl, 1915

Lestica Billberg, 1820

\section{Lestica clypeata (Schreber, 1759)}

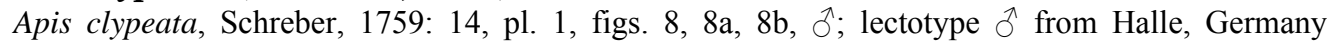
(LSUK). [Kohl, 1915.]

\section{Egyptian synonyms:}

In coll CGR there are $2 \hat{\partial} \widehat{o}$ from Qaha., the first record of this species from Egypt.

Range: Europe, Middle East, Egypt

Distribution: Qaha

Flight: males (6)

Collections: CGR (First record from Egypt) 
Lindenius Lepeletier \& Brullé, 1835

ibericus species group

Lindenius difficillimus (Kohl, 1915)

Crabro (Lindenius) difficillimus Kohl, 1915: 309-310,, ; holotype $\$$ from Egypt - Siala nr Fayoum (OUM)

Egyptian synonyms:

Crabro (Lindenius) difficillimus Kohl, 1915

Lindenius difficillimus

de Beaumont, 1956b \& 1960a; Bohart \& Menke,

Range: Algeria, Libya (Cyrenaica), Egypt 1976.

Distribution: Fayyum (Siala)

Flight: females (3)

pygmaeus species group

Lindenius haemodes (Kohl, 1905)

Crabro (Lindenius) haemodes Kohl, 1905: 222, $\odot$; syntype $\odot$ from Egypt - Helwan (NHMW). [Kohl, 1915.]

Egyptian synonyms:

Crabro (Lindenius) haemodes

Lindenius haemodes

Kohl, 1915.

Honoré, 1942; de Beaumont, 1956b; Bohart \&

Range: Egypt, Ethiopia

Menke, 1976.

mesopleuralis species group

\section{Lindenius aegyptius (Kohl, 1888)}

Lindenius aegyptius Kohl, 1888: 134, + ; holotype $q$ from Egypt (NHMW). [Kohl, 1915.]

Egyptian synonyms:

Crabro (Lindenius) aegyptius Kohl, 1915.

Lindenius aegyptius Honoré, 1942; de Beaumont, 1956b; Pulawski,

Range: Spain, Morocco, Libya (Tripolitania), Egypt

1964. Bohart \& Menke, 1976.

Distribution: Helwan, Kom Awshim, 10th Ramadan City

Flight: males $(5,9)$, females $(7,9)$

Collections: CGR, WJP

\section{BEMBECINAE}

Nyssonini

Nysson Latreille, 1802-1803

\section{Nysson laevis Pulawski, 1964}

Nysson laevis Pulawski, 1964: 78-81, ô, + ; holotype in WJP, loc. typ. Egypt - Maadi.

Egyptian synonyms:

Nysson laevis

Pulawski, 1964; Bohart \& Menke, 1976.

Range: Egypt

Distribution: Abu Rawash, Dahshur, Giza, Kerdasa, Kom Awshim, Maadi

Flight: males (3-5), females $(4-5,11)$

Collections: CGR, WJP

Nysson rufus Handlirsch, 1895 
Nysson rufus Handlirsch, 1895: 811-813, + ; holotype $q$ from 'Egypt' (MZL).

Egyptian synonyms:

Nysson rufus

Handlirsch, 1895; Pulawski, 1964; Bohart \&

Range: Egypt

Menke, 1976.

Distribution: Kom Awshim

Flight: males (5)

Collections : WJP

Bembecini

Ammatomus A. Costa, 1859

\section{Ammatomus coarctatus (Spinola, 1808)}

Gorytes coarctatus Spinola, 1808: 245; syntype đิ from Italy - Liguria, near Novas (IMZUT). [Handlirsch, 1888; Pulawski, 1973.]

Egyptian synonyms: Gorytes coarctatus

Storey, 1916.

Range: S Europe, Algeria, Egypt, Cyprus, Turkey, sw USSR, Iran

Distribution: Cairo (The Barrages), Dakhla Oasis (Al Qasr), Kerdasa, Kom Awshim

Flight: males $(5,7,9)$, females (4)

Collections: CGR (First record from Egypt)

\section{Ammatomus mesostenus (Handlirsch, 1888)}

Gorytes mesostenus Handlirsch, 1888: 345-346, + ; holotype + in coll. Marquet, MZL; loc. typ. Egypt.

Egyptian synonyms:

Gorytes mesostenus Handlirsch, 1888; Honoré, 1942.

Gorytes (Ammatomus) mesostenus de Beaumont, 1950c.

Ammatomus mesostenus

de Beaumont, 1956a; de Beaumont \& BytinskiSalz, 1959; Pulawski, 1964 \& 1973; Bohart \& Menke, 1976.

Range: Libya (Cyrenaica), Egypt, Israel, Oman, Iraq, Iran. The subspecies Ammatomus $m$. rhopalocerus (Handlirsch) is stated to occur in Morocco and Algeria; in the absence of any further information, it is presumed that the reference to Libya (Cyrenaica) is to the nominotypical form.

Distribution: Cairo, Hawamdieh, Kom Awshim, Maadi, Siwa Oasis

Flight: males (3-4), females $(4-5,10)$

Collections: CGR, WJP

\section{Bembecinus A. Costa, 1859}

tridens species group

\section{Bembecinus tenellus (Klug, 1845)}

Larra tenella Klug, 1845, pl.46, fig. 8, §̊, , , type in ZMHU; loc. typ. 'Egypt' (Sudan). [Handlirsch, 1892; de Beaumont, 1954b.]

Egyptian synonyms:

Stizus tenellus

Stizus (Bembecinus) tenellus

Range: Egypt, Sudan

Distribution: Aswan, Giza, Maadi; "assai commune ai margini del deserto" (Mochi, 1939b)

Flight: males (2), females (2) "in primavera e sopratutto in estate" (Mochi, 1939b)

Collections: CGR, WJP
Mochi, 1939c; Honoré, 1942.

de Beaumont, 1950a \& 1954b; Pulawski, 1964. 


\section{Bembecinus argentifrons (F.Smith, 1856)}

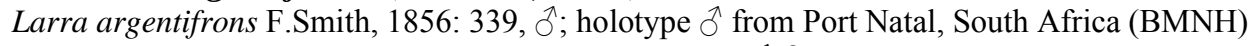
Bembecinus touareg de Beaumont, 1954b: 253-255, §ิ,, ; type in MZL; loc. typ. Hoggar, central Sahara. Synonymised by Schmid-Egger 2004: 22

Egyptian synonyms: Bembecinus touareg

Bohart \& Menke, 1976.

Range: Egypt, Central Sahara

Bembix Fabricius, 1775

chlorotica species group

Bembix chlorotica Spinola, 1839

Bembex chlorotica Spinola, 1839: 469, $q$; lectotype $q$ in ZMHU, from Egypt, probably Saqqara. [Handlirsch, 1893; Priesner, 1958; Guichard, 1989a.]

Egyptian synonyms:

Bembex chlorotica

Handlirsch, 1893; Storey, 1916; Honoré, 1942.

Bembix chlorotica

Bembyx chlorotica

Bohart \& Menke, 1976; Guichard, 1989a.

Diagnosis: (3 우 examined.)

Priesner, 1958.

우: Colour - yellow except, black: apex of mandibles; frons with an area shaped like a papilionid butterfly upper side of Ant2-12 (apically tending to be brownish); vertex behind the mid ocellus; pronotum mesally; mesonotum, except lateral and posterior yellow bands; scutellum, except posterior band; metanotum; dorsum and posterior area of propodeum after anterior band; legs with black stripe on upper (posterior) surface of trochanters, femora and narrowly the tibiae; pulvillae black; T1-5 (greenish yellow) except mesal black band widening either side of median line; T6 black with apical yellow (not greenish) area; S2 with small mesal black mark and one in each antero-lateral angle; S3-5 as S2 but the black marks increasing in size; S6 black except for 2 apical yellow spots. Silver appressed pubescence on base of clypeus and laterally on frons. Longer white hairs on head, thorax and T1. Shorter pale hairs on rest of abdomen except stout black bristles on T6. Wings hyaline, the veins brown, except subcosta black up to SMC1. Morphology- Ant3 subequal to Ant1; clypeus in profile slightly convex, the lateral areas lightly depressed; fore-metatarsus with 7-8 rather spatulate spines; S2 without obvious punctures; T6 yellow apex rounded and smooth, shallow punctures; hindwing submedial cell with posterior angle obtuse. Length: $14-15 \mathrm{~mm}$.

Range: Spanish Sahara, Egypt

Distribution: Kerdasa

Flight: males (4), females (4)

Collections: CGR

\section{fischeri species group}

\section{Bembix fischeri Spinola, 1839 ssp. fischeri (s.s.)}

Bembex Fischeri Spinola, 1839: 470, o; holotype + in MRSN; loc. typ. Egypt. [de Beaumont, 1956a]

Egyptian synonyms:

Bembex Fischeri

Bembix fischeri

Bembyx fischeri

Range: Egypt
Handlirsch, 1893; Honoré, 1942;

de Beaumont, 1956a; Bohart \& Menke, 1976.

Priesner, 1958.

\section{Bembix rufiventris Priesner, 1958}

Bembyx rufiventris Priesner, 1958: 19-20, ô, + ; holotype $\widehat{\jmath}$ in PPDD; loc. typ. Egypt - Helwan. Egyptian synonyms:

\section{Bembyx rufiventris}

Bembix rufiventris

Diagnosis: (9 males and 3 females examined.)
Priesner, 1958.

Bohart \& Menke, 1976; Guichard, 1989a. 
Colour: head yellow, except black: apex of mandibles; 2 longitudinal stripes on frons extending upwards from antennal sockets to before the mid-ocellus; vertex; antennae of $\delta$ have anterior of Ant1 yellow; this may extend up to Ant3 after which remainder is usually ferruginous below; the upper surface is black; antennae of $q$ ferruginous, but Ant1 is yellow in its basal half then black on the upper side; this black may continue to Ant3; pronotum yellow, except often (normally in 9 ) three black spots dorsally, the middle one of which is much smaller than the others; mesonotum black, except yellow lateral lines by the tegulae and two very narrow longitudinal ones on the disk; tegulae yellow or pale in front and brown behind; scutellum black with yellow lateral and posterior margins; metanotum black with a black posterion margin; propodeum with a U-shaped yellow band enclosing a black dorsal area; laterally and posteriorly yellow; mesopleurae yellow in upper anterior part, black below and posteriorly; metapleurae yellow; mesosternum black with a small yellow area between the mid-coxae; legs yellow, except femora 1 (and sometimes also the trochanters) with a black stripe behind; femora $2 \& 3$ with smaller darker stripes above, these femora rather reddish yellow; all coxae \& trochanters $2 \& 3$ are usually darker, particularly on anterior surface; all pulvillae black; tergites with a pale mesal band of greenish yellow which has a reddish tinge anteriorly and posteriorly; before this is a black basal band which is wider in the middle, in T2 this wider part may be detached as two spots; apically is a dark band, black on T1-4 (narrower on T4) and red on T6 in $ठ$ and T5 in 9 ; $\mathrm{T} 7$ in $\delta$ has a ferruginous mesal spot apically whilst in the $q \mathrm{~T} 6$ is entirely reddish yellow; sternites are reddish in the middle and yellow laterally; S2 has two small black spots; subsequent sternites may have black basal areas; $\mathrm{S} 6$ of the $q$ is sometimes darker than the other sternites; S7 in the $\delta$ is black. Slight silver appressed pubescence on the base of the clypeus and on the frons; longer white hairs on the frons, vertex and temples (especially below in the $\overbrace{}^{\Uparrow}$ ); shorter white hairs on the thorax and T1. Wings hyaline, with the veins brown, reddish brown basally.

Morphology: clypeus swollen in profile; anteriorly, there is a mesal triangular area which is somewhat depressed; Ant $3>$ Ant 1; metatarsus 1 with 6 spines; S2 in the $\hat{\sigma}$ with a large curved carinate process, pointed at its apex; in both the sexes the sternite is more finely and densely punctate than S3; T6 of $q$ is punctate but less so in the middle apically; S6 of $\delta$ has a flat raised triangular plate; T7 is rounded apically with a mesal impression; parameres are fairly broad, the outer side straight and the inner one gently emarginate halfway, the apices rounded; posterior angle of the hindwing submedial cell a right angle or somewhat obtuse. Length: males 16-19 mm., females $15 \mathrm{~mm}$.

Range: Egypt, Sinai

Distribution: Ain Sokhna road (50-85km E of Maadi), Wadi Digla. Sinai - Umm Bugma

Flight: males (4-6), females (4-6)

Collections: CGR

\section{fuscipennis species group}

\section{Bembix capensis Lepeletier, 1845}

Bembex Doriae Magretti, 1884: 590, pl. 1, fig. 14, đ̊, o, holotype in Spinola coll. (location?), from Cape Province, South Africa. [Handlirsch, 1893; Priesner, 1958.]

Guichard, 1989a, agreed with Priesner's suspicions that doriae was a synonym of capensis.

\section{Egyptian synonyms:}

Bembyx doriae

Priesner, 1958.

Diagnosis: (7 males and 4 females examined.)

Males: Colour - head black, except yellow-ferruginous areas (mandibles, dark apically; labrum; clypeus; narrow stripe along inner orbits; small stripe above each antennal socket; frons with 2, 3 or 4 transverse spots before the anterior ocellus; sometimes these spots join together with the inner orbital stripes; scape, usually a black stripe above; stripe on temples behind the eyes) and light ferruginous on the underside of the antennae. Thorax black, except yellow-ferruginous on pronotum with narrow stripe wider at the tubercles, and extending downwards; mesonotum with stripe laterally by each tegula; scutellum, posterior margin; postero-lateral angles of the propodeum; sometimes also a dorsal U-shaped area; mesopleurae with an anterior vertical stripe running down from the pronotal tubercles at the margin with the pronotum; sometimes a vertical stripe at the posterior margin. Abdomen black with yellow transverse bands on T1-T5 (T1 has an orange tinge), sometimes T6 has a yellow band also; in one example examined T7 was a dull ferruginous; T2 with two free detached black spots; S1-S3 and S5-S6 ferruginous with yellow lateral spots on S2-S4; sometimes the whole ventral surface is ferruginous. Legs 1 with coxae 
yellow anteriorly, femora dark basally then yellow-ferruginous, tibiae and tarsi yellowferruginous, claws and pulvillae black. Legs 2 and 3 as Legs 1 but coxae black, femora with less basal black and tarsi more yellow than yellow-ferruginous. Silver appressed pubescence on clypeus. Head with long white hairs. Thorax with long white hairs laterally and ventrally and dorsally with short pale ferruginous hairs. Abdomen with very short very pale ferruginous pubescence. Wings hyaline, the veins of the forewing dark, except the costa which is brown, and all red brown basally; those of the hind wing are a light brown, red-brown. Morphology mandibles with a small inner tooth; clypeus in profile protuberant; Ant 1 curved and thickened apically, longer than Ant 3; antennae apically considerably distorted, Ant 11 and 12 much widened; thorax densely but finely punctate; T7 wide apically with scattered punctures; S2 process varying from a longitudinal carina to a large thick humped round-ended process; S6 with wide triangular raised platform; metatarsus 1 with 6 spines; fem 2 not dentate; lower side of metatarsus 2 produced into a rounded lobe; posterior angle of hindwing submedial cell a right-angle. Length: 14-17 mm.

Female: Colour - head black, except yellow-ferruginous on: labrum, sometimes a darker ferruginous line mesally; mandibles, black apically; inner orbits with a narrow stripe; superantennal area with spots sometimes joining the inner orbital stripes; 3 spots on frons transversely in front of the anterior ocellus; sometimes these join together and to the inner orbital stripe; temples with a stripe behind each eye; antennae, especially Ant 1, darker apically and above. Thorax black, except yellow-ferruginous on: pronotum with stripe widening laterally by the tubercles; mesonotum with stripes laterally by the tegulae and sometimes two short anterior mesal stripes; scutellum with a narrow stripe along the posterior margin; propodeum with a U-shaped mark round the dorsal area and the postero-lateral angles; the propodeal marks are a more clear yellow than elsewhere. Abdomen black with yellow bands on T1-T5; T2 with two black separate spots as sometimes has T3; T6 ferruginous; S1-S2 and S6 ferruginous; lateral yellow spots on S2-S6. Legs yellow- ferruginous except the base of the femora, claws and pulvillae. Wings hyaline, the veins black and brown. Morphology - clypeus protuberant, the margin regularly emarginate; Ant 1 slightly longer than Ant 3; mesonotum densely and finely punctate; T6 rounded and punctate; S2 mesally shining with scattered punctures, laterally densely and more finely punctate; metatarsi 1 with combs comprising 6 spines; posterior angle of hindwing submedial cell a right angle. Length 15-17 mm.

Range: N Africa

Distribution: Sinai - Wadi Gebel

Flight: males (8), females (8)

Collections: CGR, SZ

\section{hedickei species group}

\section{Bembix alfierii Priesner, 1958}

Bembyx alfierii Priesner, 1958: 10-13, đึ,, ; holotype $\widehat{\partial}$ in coll. Alfieri (AUCE); loc. typ. Egypt Kerdasa.

Egyptian synonyms: Bembyx alfierii Priesner, 1958.

Bembix alfierii Bohart \& Menke, 1976.

Range: Egypt

Bembix palaestinensis Lohrmann, 1942

Bembix palaestinensis Lohrmann, 1942: 208, §’; holotype $\lesssim$ in ZSMC; loc. typ. Palestine. Egyptian synonyms:

Bembix palaestinensis Lohrmann, 1948.

Bembyx palaestinensis $\quad$ Priesner, 1958.

Range: Tunisia, Israel (?)

megerlei species group

Bembix kohlii Morice, 1897

Bembex kohli Morice 1897a: 313, pl. VI, figs. 32-34, §, , ; syntypes from Saqqara (OUM)

Egyptian synonyms:

Bembex kohli

Morice, 1897a. 
Bembex Kohli

Bembix kohli

Bembyx kohli

Bembix kohlii

Range: Egypt, Israel, Oman, UAE

Distribution: Saqqara, Abukir near Alexandria
Honoré, 1942.

Lohrmann, 1948; de Beaumont, 1966; Guichard, 1989a.

Priesner, 1958.

de Beaumont \& Bytinski-Salz, 1955; Bohart \& Menke, 1976.

\section{Bembix nilotica Priesner, 1958}

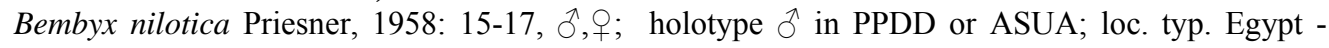
Abukeer.

Egyptian synonyms:

Bembix nilotica

Priesner, 1958; Bohart \& Menke, 1976; Guichard, 1989a.

\section{Bembix pallescens Priesner, 1958}

Bembyx pallescens Priesner, 1958: 17, nec Giorna, 1791, ô, , ; holotype ô originally in PPDD, now NHMW; loc. typ. Egypt - Khanka.

Egyptian synonyms:

Bembix pallescens

Priesner, 1958; Bohart \& Menke, 1976; Guichard, 1980 \& 1989a.

\section{Bembix portschinskii Radoszkowski, 1884}

Bembex Portschinskii Radoszkowsky, 1884: 26, $\sigma^{\wedge}$; holotype $\hat{\sigma}$ in ZMJU, from Caucasus. [Handlirsch, 1893.]

Egyptian synonyms: Bembex portschinskii

Storey, 1916.

\section{Bembix priesneri de Beaumont, 1966}

Bembix priesneri de Beaumont, 1966: 209-211, ô; holotype ô in MZL; loc. typ. Egypt - Fayed. Egyptian synonyms:

Bembix priesneri

de Beaumont, 1966; Bohart \& Menke, 1976; Guichard, 1989a.

\section{Bembix sp.}

Bembyx sp

Priesner, 1958

Priesner, 1958, described without naming a hitherto undescribed species.

oculata species group

\section{Bembix abragensis Priesner, 1958}

Bembyx abragensis Priesner, 1958: 31, đo,, ; type in PPDD; loc. typ. Egypt - Wadi Abrag (South Eastern Desert) ( $($ ), Gebel Elba, Wadi Kansisrob ( $\overbrace{}^{\Uparrow})$.

Priesner does not make it clear which sex is the holotype. He describes the 0 first but then says of it that he "would like to have put aside until further material would be available." He then lists the type material with the $q$ first.

Egyptian synonyms:

Bembix abragensis

Priesner, 1958; Bohart \& Menke, 1976.

\section{Bembix flavescens F. Smith, 1856 ssp. kittyae de Beaumont, 1957}

Bembex flavescens F. Smith, 1856: 321, ơ ; loc. typ. Canary Is. (BMNH) [Handlirsch, 1893.]

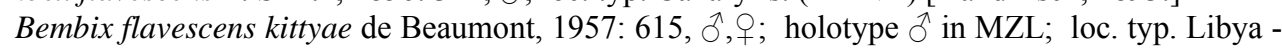
Tripolitania, Gargaresc.

Egyptian synonyms:

Bembex turca Dahlbom, 1845

Bembyx turca

Bembix turca Handlirsch (lapsus)
Storey, 1916 (misidentification). Priesner, 1958 (misidentification). de Beaumont, 1956a. 
Bembix flavescens kittyae

de Beaumont, 1957,1966; Bohart \& Menke, 1976.

Range: Tunisia, Libya, Egypt

Distribution: Alexandria area (Abukir, Agami, S Abd el Rahman)

Bembix flavescens F. Smith, 1856 ssp. picturata Bytinski-Salz, 1955

Bembix turca picturata Bytinski-Salz in de Beaumont \& Bytinski-Salz, 1955: 49-50. §, o; type in coll. BYS-TAUI; loc. typ. Israel - Bat Yam.

Egyptian synonyms:

Bembix flavescens picturata de Beaumont, 1957.

Bembyx turca picturata Priesner, 1958.

\section{Bembix freygessneri Morice, 1897}

Bembex frey-gessneri Morice, 1897a:315, pl, VI, figs. 40-43, §; holotype $ð$ from Egypt - Koubbeh nr. Cairo (OUM).

Bembyx frey-gessneri v. decipiens Priesner, 1958 30, $q$.

Bembix dissimilis WF Kirby, 1900: 22, ๆ; type from Abd el-Kuri Isl., Yemen (BMNH) [Bohart \& Menke, 1976.]

Egyptian synonyms:

Bembex frey-gessneri Morice, 1897a.

Bembex Frey-Gessneri Honoré, 1942.

Bembix freygessneri de Beaumont, 1958d; Bohart \& Menke, 1976.

Bembix frey-gessneri Lohrmann, 1948.

Bembyx frey-gessneri Priesner, 1958.

Bembyx frey-gessneri var. decipiens $\quad$ Priesner, 1958.

Bembix dissimilis

Bohart \& Menke, 1976.

Bembix decipiens

Bohart \& Menke, 1976.

\section{Bembix melanura F. Morawitz, 1889}

Bembex melanura F. Morawitz, 1889: 141, §̊; holotype § from China (ZIL). [Handlirsch, 1893; Priesner, 1958.]

Egyptian synonyms:

Bembix melanura

de Beaumont, 1957; de Beaumont, 1960a.

Bembyx melanura

Priesner, 1958.

\section{Bembix oculata Panzer, 1801 ssp. soror Dahlbom, 1845}

Bembex oculata Panzer, 1801 (no details available) Bembex oculata Panzer of Latreille, 1804-5 [Bohart \& Menke, 1976.]

Bembex oculata Latreille, 1805: 301. [Handlirsch, 1893; Priesner, 1958.]

Bembex soror Dahlbom, 1845: 489, + ; holotype $q$ in NRS, from 'Egypt'. [Priesner, 1958.]

Egyptian synonyms:

Bembix oculata Geer (sic)

Bembex oculata Latreille

Innes, 1911.

Storey, 1916.

Bembex oculata Egyptian form Handlirsch, 1893.

Bembex oculata forma soror Honoré, 1942.

Bembix oculata soror de Beaumont \& Bytinski-Salz, 1955; Osborn \&

Krombein, 1969; Bohart \& Menke, 1976. The record of Osborne \& Krombein, 1969, is from Gebel 'Uweinat, but from the Sudanese part.

Bembyx oculata soror

Priesner, 1958.

ssp.

de Beaumont, 1950c, 1956a \& 1958d.

de Beaumont, 1950c \& 1958d, described the Siwa race as quite distinct from ssp. soror, and much more like the form found in Morocco.

\section{Bembix radoszkowskii Handlirsch, 1893}

Bembex Radoszkowskyi Handlirsch, 1893: 865-866, pl. 3, fig. 11, pl.7, fig. 36, ठิ, ?+; syntypes from Senegal (NHMW) and Sudan (ZMJU).

Egyptian synonyms:

Bembex radoszkowskyi

Bembyx radoszkowskyi
Morice, 1911; Storey, 1916.

Priesner, 1958. 
olivacea species group

\section{Bembix arenaria Handlirsch, 1893}

Bembex arenaria Handlirsch, 1893: 823-824, §̋, of; syntypes from Syria (NHMW, TMB).

Egyptian synonyms:

In coll. CGR. Taken at Rafah, Sinai, the first record from Egypt.

\section{Bembix chopardi Berland, 1950}

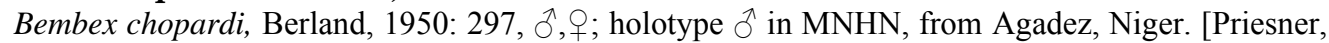
1958; Guichard, 1989a.]

Egyptian synonyms:

Bembyx chopardi

Priesner, 1958.

\section{Bembix dahlbomii Handlirsch, 1893 ssp. dahlbomii (s.s.)}

? Bembex glauca Dahlbom, 1845: 491, ô,o; loc. typ. India \& Egypt, nec Fabricius, 1787. Tentatively synonymised with dahlbomi by Handlirsch, 1893: 806

Bembex Dahlbomi Handlirsch, 1893: 806-7, §̊,, ; syntypes from Algeria, Tunisia, Sudan, Eritrea and 'Cosseir' (NHMW, TMB, MZUN, SMNS)

Egyptian synonyms:

Bembex dahlbomii Storey, 1916.

Bembex Dahlbomi Honoré, 1942.

Bembyx dahlbomi Priesner, 1958.

Bembix dahlbomi de Beaumont, 1950c.

Bembix dahlbomii Guichard, 1989a.

\section{Bembix lusca Spinola, 1839}

Bembex lusca Spinola, 1839: 467, §ิ,q; lectotype $q$ from 'Egypt' (MRSN), designated by Beaumont, 1952: 45. [Handlirsch, 1893; Priesner, 1958.]

Egyptian synonyms:

Bembex lusca Handlirsch, 1893; Storey, 1916; Honoré, 1942.

Bembix lusca de Beaumont, 1966; Bohart \& Menke, 1976.

Bembyx lusca Priesner, 1958.

\section{Bembix maidli Schulthess, 1927}

Bembex maidli Schulthess, 1927: 302, ð̊; holotype đ̋ in DEI, from Port Sudan.

Egyptian synonyms:

Bembix maidli Lohrmann, 1948.

\section{Bembix olivacea, Fabricius, 1787 ssp. saharae Giner Marí, 1945}

Bembix olivacea Fabricius, 1787: 285; lectotype $\delta$ in ZMK, from Tunisia [Priesner, 1958; Guichard, 1989a.]

Bembex mediterranea Handlirsch, 1893: 807, §, , ; syntypes from many localities including Egypt (depositories not indicated)

Bembex saharae Giner Marí, 1945: 380, đ̊, o, syntype đ̊ from El Aiun, Western Sahara (IEEM) [Priesner, 1958]

Egyptian synonyms:

Bembix olivacea

Bembex mediterranea

Bembix olivacea saharae

Bembyx olivacea saharae
Innes, 1911.

Handlirsch, 1893; Storey, 1916; Honoré, 1942.

de Beaumont \& Bytinski-Salz, 1955; de Beaumont, 1958d; de Beaumont, $1967 \mathrm{~b}$.

Priesner, 1958. 
rostrata species group

\section{Bembix nasuta Morice}

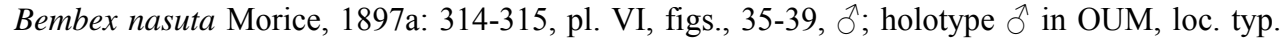
Egypt - Cairo.

Egyptian synonyms:

Bembex nasuta

Morice, 1897a; Honoré, 1942; Storey, 1916.

Bembix nasuta

Lohrmann, 1948; Bohart \& Menke, 1976.

Gorytes Latreille, 1804

Gorytes foveolatus Handlirsch, 1888 ssp. longicornis Handlirsch, 1898

Gorytes foveolatus Handlirsch, 1888b: 485, ${ }^{\circ}$,, ; lectotype ${ }^{\lambda}$ in NHMW, from Croatia Gorytes longicornis Handlirsch, 1898: 488, ${ }^{\lambda}$; lectotype ${ }^{\lambda}$ from Tlemcen, Algeria (NHMW)

Egyptian synonyms:

Gorytes longicornis

Honoré, 1942.

Range: Europe, n Africa, Middle East, Turkey

\section{Gorytes sulcifrons (A.Costa, 1867)}

Gorytes sulcifrons A. Costa, 1867: 65, + ; holotype $q$ from Sardegna, Italy (MZUN). [Handlirsch, 1888.]

Egyptian synonyms:

Gorytes sulcifrons

Range: e \& s Europe, sw USSR

Honoré, 1942.

\section{Harpactus Shuckard, 1837}

Harpactus castor (Handlirsch, 1898)

Gorytes castor Handlirsch, 1898: 487, ô; syntypes from Oran (Algeria) \& Turah (Egypt) (NHMW)

Egyptian synonyms:

Gorytes castor

Honoré, 1942.

Gorytes (Dienoplus) castor de Beaumont, 1956a.

Range: Algeria, Egypt

\section{Harpactus laevis (Latreille, 1792) ssp. aegyptiacus (Schulz, 1904)}

Mutilla laevis Latreille, 1792: 12; holotype from sw France (lost). [Handlirsch, 1888.]

Gorytes laevis aegyptiacus Schulz, 1904: 96, ơ; holotype from 'Egypt' (?MZSF)

\section{Egyptian synonyms:}

Gorytes laevis

Handlirsch, 1888 (I presume that Handlirsch referred to the future subspecies and not his own

Gorytes (Harpactus) laevis typical form.); Honoré, 1942.

Gorytes (Dienoplus) laevis

Morice, 1911.

Gorytes (Dienoplus) laevis aegyptiacus

de Beaumont, 1958d.

Dienoplus laevis aegyptiacus

de Beaumont, 1956a; Pulawski, 1964.

Bohart \& Menke, 1976.

Range: Algeria (Tassili des Ajjer), Libya (Fezzan), Egypt

Distribution: Abu Rawash, Abydos, Aswan, Gebel el Asfar, Giza, Giza (Pyramids), Hawamdieh, Kom Awshim, Maadi, Wadi el Natrun, $35 \mathrm{~km}$ E of Wadi el Natrun

Flight: males $(2-4,6,11)$, females $(2-3,5-6,10-11)$

Collections: CGR, WJP

\section{Harpactus lunatus (Dahlbom, 1832)}

Larra lunata Dahlbom, 1832: 52, + ; syntype $q$ from Sweden (MZLU)

Egyptian synonyms:

Gorytes lunatus

Honoré, 1942. 
Range: Eurasia

\section{Harpactus pollux (Handlirsch, 1898)}

Gorytes pollux Handlirsch, 1898: 487, ð,,, ; syntypes in NHMW, from Oran (Algeria) and Turah (Egypt)

Egyptian synonyms:

Gorytes pollux Honoré, 1942.

Range: N. Africa

Hoplisoides Gribodo, 1884

ferrugineus species group

\section{Hoplisoides ferrugineus (Spinola, 1839)}

Hoplisus ferrugineus Spinola, 1839: 497-498, ठ̊ં; type from 'Egypt' lost, neotype $q$ from Egypt Shubra (BMNH). de Beaumont, $1952 \mathrm{~b}$.

Egyptian synonyms:

Gorytes ferrugineus $\quad$ Handlirsch, 1888; Honoré, 1942.

Hoplisoides ferrugineus de Beaumont, 1952b; Pulawski, 1964.

Gorytes (Hoplisoides) ferrugineus de Beaumont \& Bytinski-Salz, 1959.

Range: N Africa, Egypt, Oman

Distribution: Cairo, Kom Awshim, Shubra

Flight: males (5), females $(4,11)$

Collections: CGR, WJP

Kohlia Handlirsch, 1895

Kohlia coxalis Morice, 1897

Kohlia coxalis Morice, 1897a: 311-312, pl.VI, figs.23-27, §̊, , ; loc. typ. Egypt - Cairo (OUM)

Egyptian synonyms:

Kohlia coxalis

Morice, 1897a; Honoré, 1942; de Beaumont \&

Range: n Africa, Egypt, Israel

Bytinski-Salz, 1959; Pulawski, 1964.

Distribution: Abu Rawash, Dahshur, Fayyum, Giza, Kom Awshim, Koubbeh, Saqqara, Wadi Digla

Flight: males (4-5), females (4-5)

Collections: CGR, KMG, WJP

Psammaecius Lepeletier, 1832

Psammaecius eremorum de Beaumont, 1952

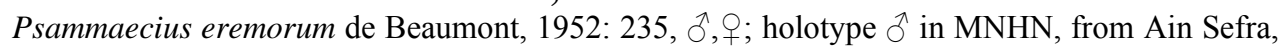
Algeria

Egyptian synonyms:

Coll. Mochi has a specimen determined de Beaumont

Sphecius Dahlbom, 1843

\section{Sphecius claripennis Morice}

Sphecius claripennis Morice, 1911: 126-127, đ̂,,+ ; holotype in OUM; loc. typ. Algeria - Biskra. Egyptian synonyms:

Sphecius claripennis de Beaumont, 1950c. 
De Beaumont, 1950c, stated that morphologically the Siwa specimens are similar to those from the type locality, Biskra, but the coloration is different.

\section{Stizoides Guérin-Méneville, 1844}

\section{Stizoides abdominalis (Dahlbom, 1845)}

Stizus abdominalis Dahlbom, 1845: 478, §ิ; holotype $\widehat{\jmath}$ from 'Egypt', whereabouts unknown. [Handlirsch, 1892.]

Egyptian synonyms: Stizus abdominalis Stizoides abdominalis Handlirsch, 1892; Mochi, 1939c; Honoré, 1942.

Range: Egypt

Distribution: Gebel Elba (Mochi, 1939b)

\section{Stizoides citrinus (Klug, 1845)}

Larra citrinus Klug, 1845: pl.46, fig. 4, 9 ; lectotype $q$ in ZMHU from Fayum Gov., Egypt, designated by Ohl, 1999: 108. [Handlirsch, 1892.]

Egyptian synonyms:

Stizus citrinus

Stizoides citrinus

Range: Egypt

Distribution: Kharga Oasis (Dush); [Abu Rawash, Gebel Asfar, Mansurieh (Mochi, 1939b)]

Flight: males (7), females (6-7)

Collections: CGR; [AM sr \& PPDD (Mochi, 1939,b)]

\section{Stizoides crassicornis (Fabricius, 1787)}

Tiphia crassicornis Fabricius, 1787: 178; lectotype $q$ from Tunisia, in ZMK [Handlirsch, 1892.]

Egyptian synonyms:

Stizus crassicornis

Stizoides crassicornis

Handlirsch, 1892.

De Beaumont \& Bytinski-Salz, 1955, were not certain of its presence in Egypt.

Range: S Europe, SW USSR, Turkey, Cyprus, Israel, Egypt?

\section{Stizoides klugii (F.Smith, 1856)}

Larra apicalis Klug, 1845: Pl. 40, fig. 13 (nec Guérin-Méneville, 1844), đ̊; holotype đ̊ in ZMHU, from "Arabia felix", now Saudi Arabia. [Handlirsch, 1892.]

Larra Klugii F. Smith, 1856: 345; substitute name [Handlirsch, 1892.]

\section{Egyptian synonyms:}

Stizus Klugii

Stizus apicalis

Stizus Klugi

Stizoides klugii

Handlirsch, 1892.

Storey, 1916.

Mochi, 1939c; Honoré, 1942.

de Beaumont \& Bytinski-Salz, 1955; Bohart \& Menke, 1976; Guichard, 1989b.

Range: Saudi Arabia, Yemen, Algeria, Egypt, Israel

Distribution: Kafr Hakim (Mochi, 1939b)

Flight: females (5)

Collections: Alfieri (Mochi, 1939b)

\section{Stizoides melanopterus (Dahlbom, 1845)}

Stizus melanopterus Dahlbom, 1845: 478, ' $\not$ ' $=\widehat{\jmath}$; holotype $q$ from Rhodes, Greece (MZLU). [Handlirsch, 1892.]

Egyptian synonyms:

Stizoides melanopterus

de Beaumont \& Bytinski-Salz, 1955, citing Savigny pl.16 fig.24.

Range: Egypt ?, Israel, Cyprus, se Europe, Asia Minor, Oman, sw USSR 


\section{Stizoides assimilis (Fabricius, 1787)}

Sphex assimilis Fabricius, 1787: 276; lectotype $\widehat{\delta}$ from Tamil Nadu, India (ZMK)

Stizus poecilopterus Handlirsch, 1892: 111-112,, ; syntype in NHMW, from Sudan. Synonymised with assimilis by Ohl 1999: 81

Egyptian synonyms:

\section{Stizus poecilopterus}

Stizoides poecilopterus
Storey, 1916; Mochi, 1939c; Honoré, 1942;

de Beaumont \& Bytinski-Salz, 1955; Guichard, $1989 \mathrm{~b}$.

Range: Ethiopia, Sudan, Egypt, Israel, Iran

Distribution: Fayyum (Karanis); "Le specie è piuttosto rara; si trova tanto negli Wadi che sui margini del deserto" (Mochi, 1939b)

Flight: males (8) "in piena estate, da Guigno in poi" (Mochi, 1939b)

Collections: CGR

\section{Stizoides tridentatus (Fabricius, 1775)}

Crabro tridentatus, Fabricius, 1775: 373; holotype in ZMK, from southern Europe [Handlirsch, 1892.]

Egyptian synonyms: Stizus tridentatus

Mochi, 1939c; Honoré, 1942.

Range: S Europe, N africa, Israel, Cyprus. Turkey, sw USSR

Distribution: Kafr Hakim (Mochi, 1939b)

Flight: females (5)

Collections: Alfieri (Mochi, 1939b)

Stizus Latreille, 1802-1803

aegyptius species group

\section{Stizus aegyptius Lepeletier, 1845}

Stizus aegyptius Lepeletier, 1845: 300, ô, ㅇ. [Handlirsch, 1892.] Handlirsch, 1895, adds that the 0 type designated by Klug is in ZMHU; loc. typ. Egypt - "Saccahram" [? = Saqqara]. World Catalogue has the type locality as 'Egypt'

Egyptian synonyms:

Stizus Aegyptia Handlirsch, 1892.

Stizus aegyptius $\quad$ Storey, 1916; Mochi, 1939c; Honoré, 1942;

Bohart \& Menke, 1976; Guichard, 1989b.

Guichard, 1989b, comments that "some of the Egyptian species of Stizus may occur in Arabia, but the status of ... S. aegyptius Lepeletier ... is obscure" - why he said this is not known.

Range: Egypt

\section{Stizus arnoldi Mochi, 1939}

Stizus Arnoldi Mochi, 1939c: 203-204, o; type in AM; loc.typ. 'Egypt'

Egyptian synonyms:

Stizus arnoldi

Mochi, 1939c; Honoré, 1942; Bohart \& Menke,

Range: Egypt 1976.

\section{Stizus bizonatus Spinola, 1839}

Stizus bizonatus, Spinola, 1839: 473-474, O̊,, ; lectotype $\odot$ in MRSN; loc.typ. 'Egypt'.

Egyptian synonyms:

Larra bizonata

Innes, 1911.

Stizus bizonatus

Handlirsch, 1892; Storey, 1916; Mochi, 1939; Honoré, 1942; Bohart \& Menke, 1976; Guichard, $1989 \mathrm{~b}$.

Diagnosis: (24 males and 13 females examined.) 
Colour: This species is the most uniform in its coloration of the whole genus in Egypt. Male: Black except for ferruginous on: basal half of mandibles; labrum; clypeus; frons with stripes along inner orbits and a spot between the antennal sockets, the lateral stripes sometimes meeting above bending forwards in the middle, thus forming a M-shaped pattern; the interantennal spot often joins the lateral stripes below; pronotum, the dorsal area laterally extending to the tubercles; sometimes the mesonotum laterally; sometimes the sides of the scutellum and metanotum; legs - femora (in part), tibiae and tarsi, tib 3 and metatarsi 3 much darker than the rest; T1; bright yellow on most of T2 and T3 not reaching the lateral or posterior margins. Silver pruinescence on clypeus and frons. Whitish brown hair on vertex and thorax. Wings black with purple reflections, viewed under transmitted light they are in fact brown; veins black. Female: Head ferruginous, except the apical half of the mandibles. Thorax very dark ferruginous mixed with black areas, except: pronotum lighter ferruginous; meso- and metapleurae black; abdomen as males. Pubescence and wings as males.

Morphology: Longitudinal impression on frons; S1 with basal carina; first transverse cubital vein (Rs) bent. Male - antennae with tyli on Ant8-12; Ant13 curved; T7 rounded, punctate as other tergites; S8 "trident" with lateral spines divergent and straight. Female - metatarsi with 6 spines; scutellum without mesal impression; T6 narrow but rounded; very densely punctate, the punctures arranged longitudinally tending to become striate, particularly apically; the apical margin is without any sculpture, smooth and shining. Length: Males: 15-22 mm, Females: 16-24 mm.

Range: Egypt

Distribution: Fayyum (Karanis, 28km W of Shakshuk), Gebel el Asfar, Giza (Pyramids), Ismailia, Kerdasa, Kharga Oasis (Dush), Kom Awshim, el Minia, Saqqara, Wadi Digla

Flight: males (8-9), females (6-7, 9-10)

Collections: CGR

\section{Stizus hyalipennis Handlirsch, 1892}

Stizus hyalipennis Handlirsch, 1892:142-143, pl. 2, fig. 12, §̊,, ; syntypes in NHMW, from Tor (Sinai)

Egyptian synonyms:

Stizus hyalipennis

Guiglia, 1939; Mochi, 1939c; Honoré, 1942; de Beaumont, 1950c; de Beaumont \& Bytinski-Salz, 1955; de Beaumont, 1958d; Guichard, 1989b.

De Beaumont, 1950c, stated his opinion that the species described by Mochi, 1939c, as hyalipennis was probably annulatus. The true hyalipennis lacks the fossette on the scutellum of the $q$ and therefore belongs to the fasciata species group.

Range: Spanish Sahara, Algeria, Libya (Fezzan, Cyrenaica), Egypt, Sinai, Israel

Distribution: Abu Rawash (Mochi, 1939b)

Flight: females (4)

Collections: AM sr (Mochi, 1939b)

\section{Stizus lepidus (Klug, 1845)}

Larra lepidus Klug, 1845: pl. 46, fig. 1, §; holotype $\widehat{\sigma}$ in ZMHU, from Faiyum, Egypt. [Handlirsch, 1892; Guichard, 1989b.]

Stizus Marthae Handlirsch, sensu Mochi, 1939c: De Beaumont \& Bytinski-Salz, 1955, said that marthae sensu Mochi may be this species.

Egyptian synonyms:

Stizus Marthae

Stizus lepidus

Mochi, 1939c; Honoré, 1942.

de Beaumont \& Bytinski-Salz, 1955; Bohart \&

Range: Egypt

Distribution: Kom Awshim, Fayyum (Mochi, 1939b)

Flight: males (10), females (10). "Assai raro in estate e autunno" (Mochi,1939b)

Collections: CGR 


\section{Stizus marthae Handlirsch, 1892}

Stizus Marthae Handlirsch, 1892: 143-144, pl. 2, fig. 5, đో; holotype đ̋ in NHMW, from Mraier Oasis between Biskra and Tugurt, Algeria.

Stizus cheops, sp. n., Morice, 1897a: 313, pl. VI, figs. 30 \& 31, Ô, , ; loc. typ. Egypt - Zeitoun.

Egyptian synonyms:

Stizus cheops

Morice, 1897a; Storey, 1916; Mochi, 1939c;

Lohrmann, 1943; de Beaumont, 1950c. De

Beaumont, 1950c, noted the probability that cheops is a synonym of marthae.

Stizus Cheops

Honoré, 1942.

Stizus marthae

de Beaumont \& Bytinski-Salz, 1955; Beaumont, 1956a; Bohart \& Menke, 1976; Guichard, 1989b.

Range: Algeria, Libya (Tripolitania, Fezzan, Cyrenaica), Chad (Tibesti), Egypt, Oman

Distribution: Baharia Oasis, Dakhla Oasis (Al Qasr), Fayyum (Karanis), Helwan, Kharga Oasis (Dush), Kom Awshim, Siwa Oasis, 35km E of Wadi el Natrun. "negli Wadi che ai margini del deserto" (Mochi, 1939b)

Flight: males (5-10), females (5-7, 9-10). "dalla fine della primavera a tutto l'autunno" (Mochi, 1939b)

Collections: CGR

\section{Stizus niloticus Handlirsch, 1892 ssp. niloticus (s.s.)}

Stizus Niloticus Handlirsch, 1892: 134-135, ô’; syntypes from 'Egypt' (ZMHU) and Tor, Sinai (NHMW).

Egyptian synonyms:

Stizus niloticus

Morice, 1897a; Mochi, 1939c; Honoré, 1942; Lohrmann, 1943; de Beaumont \& Bytinski-Salz, 1955; de Beaumont, 1966; Bohart \& Menke, 1976.

Diagnosis: (6 males examined.)

Male: Colour: - mandibles ferruginous in basal half and black, thereafter labrum yellow or ferruginous; clypeus yellow with a basal ferruginous area or ferruginous with a basal black area; antennae ferruginous, except for Ant1 which is yellow anteriorly, sometimes the upper (posterior) surface is darkened; frons laterally with the inner orbits yellow up to mid-ocellus level and mesally yellow up to the antennal sockets - sometimes the lateral stripes curve over to meet below the mid-ocellus, forming an M-shaped band, sometimes the lateral stripes are ferruginous above; vertex and occiput black; temples with a very narrow yellow or ferruginous line behind the eyes; pronotum variegated ferruginous, black and yellow or entirely ferruginous; mesonotum black except for ferruginous lines laterally; scutellum \& metanotum ferruginous; propodeum black except for a ferruginous U-shaped band enclosing the dorsal area - this band may be wide - ferruginous areas on the angles; metapleurae, mesopleurae and mesosternum black; legs ferruginous after the middle of the femora (fem 1) or their apices (fem $2 \& 3$ ); T1 \& 2 ferruginous basally then black, or entirely ferruginous; T3-6 yellow with darker areas apically, particularly in the middle; T7 black, narrowly ferruginous apically, or ferruginous except for a small black area basally; sternites black with dark ferruginous areas, except for S4 yellow. Silver pruinescence on clypeus and frons; short white hairs on vertex and thorax; wings yellowish, the marginal and submarginal cells 2 \& 3 distinctly infuscated. Morphology antennae with tyli on Ant8-12; S1 with carina; T7 rounded, punctate until the apical impunctate lamella; first transverse cubital vein (Rs) almost straight but slightly bent posteriorly. Length: $16-19 \mathrm{~mm}$.

Female: not yet described

Range: Libya (Fezzan, Cyrenaica), Chad (Tibesti), Egypt, Sinai, Israel, Oman

Distribution: Ain Shams (Cairo), Baharia Oasis (El Aguz), Kom Awshim, Wadi Digla, Za'afarana road $(101 \mathrm{~km}$ E of El Korimat). Sinai

Flight: males (6-9), females (7)

Collections: CGR 


\section{Stizus niloticus Handlirsch, 1892 ssp. saharae Roth, 1934}

Stizus saharae Roth, 1934: 253-255, $\hat{0}$, o ; holotype $\widehat{\sigma}$ in MNHN; loc typ. Central Sahara - Redir de Tigemt.

Egyptian synonyms: Stizus saharae

Range: Algeria, Libya, Egypt

Distribution: Siwa oasis, Abd el Rahman near Alexandria

\section{Stizus rufoniger Mochi, 1939}

Stizus rufoniger Mochi, 1939c: 204, o?; type in AM.; loc.typ. 'Egypt'

Egyptian synonyms: Stizus rufoniger

Mochi, 1939c; Honoré, 1942; Bohart \& Menke, 1976; Guichard, 1989b.

Guichard, 1989b, commented that "some of the Egyptian species of Stizus may occur in Arabia, but the status of ... S. rufoniger Mochi is obscure." - his meaning is not known.

Range: Egypt

\section{Stizus savignyi Spinola, 1839}

Stizus Savignyi, Spinola, 1839: 471-473, ô,, ; lectotype $q$ in MRSN, from 'Egypt' Stizus succineus Klug, 1845: pl. 46, fig. 3, क; type in ZMHU; loc. typ. Ambukol. [Handlirsch, 1892 \& 1895.], synonymised by de Beaumont, 1951: 46

Egyptian synonyms:

Stizus succineus

Handlirsch, 1892; Storey, 1916; Mochi, 1939c;

Stizus savignyi

Honoré, 1942; de Beaumont, 1950c.

Diagnosis: (1 male and 8 females examined.)

Males: Colour - ("yellow" used here is a rather orange-yellow) mandibles yellow, black apically; labrum yellow; clypeus yellow; antennae ferruginous, darker above, except Ant1which is entirely yellow; frons yellow to mid-ocellus; vertex variegated yellow, ferruginous \& black; pronotum yellow; mesonotum black with dark ferruginous lateral margins, wider anteriorly, and a U-shaped mark on the disk; scutellum ferruginous; metanotum ferruginous; propodeum black and ferruginous; metapleurae black; mesopleurae black and ferruginous; legs red. Abdomen: T1 basally dark, then broadly yellow with a ferruginous apical margin; T2-6 yellow with ferruginous apical margins; T7 ferruginous. Silver appressed pubescence on clypeus \& frons; short white hairs on vertex and thorax. Wings almost hyaline, a slight brownish tinge, particularly along anterior margin, part of marginal cell distinctly infuscated; veins brown. Morphology - antennae with tyli on Ant8-Ant12; frons slightly depressed above the antennal sockets but without a clear longitudinal impression; S1 without a carina; T7 apically rounded, scantily punctate, the spaces between punctures greater than the punctures, except finely and densely punctate around the apical margin; first transverse cubital vein (Rs) distinctly bent. Length: $21 \mathrm{~mm}$.

Females: Colour - Ferruginous except: orange-yellow mandibles, dark apically; labrum; clypeus; frons to mid-ocellus; Ant 1; T1 yellow after ferruginous basal area, with a ferruginous apical margin; T2-6 yellow except laterally and the apical margin which is wider in T6; T7 entirely ferruginous; sometimes on the abdomen black is mixed with the ferruginous colour. Silver appressed pubescence on labrum, clypeus, frons, vertex and much of the thorax. Short white hairs on propodeum. Wings as in male. Morphology - metatarsi 1 with 6/7 spines and a number of shorter ones between; S1 no carina; T6 rounded, punctate; scutellum without mesal impression; first transverse cubital vein (Rs) bent. Length: 20-25 mm.

Range: Chad (Tibesti), Sudan, Egypt, Israel

Distribution: Baharia Oasis (El Aguz), Dakhla Oasis (Tineida), Kharga Oasis

Flight: males (6-7), females (7)

Collections: CGR 


\section{Stizus vespoides (Walker, 1871)}

Larra vespoides Walker, 1871: 25, ; holotype destroyed, from Rafla, Eritrea. [Handlirsch, 1892.]

Egyptian synonyms:

Larra vespoides

Stizus vespoides

Innes, 1911.

Handlirsch, 1892; Storey, 1916; Guiglia, 1939;

Mochi, 1939c; Honoré, 1942; de Beaumont, 1950c; de Beaumont \& Bytinski-Salz, 1955.

De Beaumont, 1950c, said the Siwa specimens had a very characteristic colour form.

Diagnosis: (24 males examined.)

Male: Colour - the dark colour varies from black to ferruginous not only between specimens but within one specimen. Head: mandibles ferruginous, black apically; labrum yellow; clypeus yellow; antennae ferruginous, sometimes darker above; Ant1 always with a yellow area below; frons yellow to mid-ocellus; vertex from mid-ocellus dark; temples dark except for a very narrow yellow stripe immediately behind the eyes. Thorax: entirely dark except a narrow yellow line along the posterior margin of the pronotum; legs ferruginous, sometimes frankly red. Abdomen yellow except: T1 entirely dark; T2 dark basally and laterally, with a dark apical border; T3 dark laterally and a dark apical border; T4-7 with vague irregular ferruginous areas; S1-4 dark; S5-7 yellow and ferruginous. Appressed pubescence on head and thorax, silver on clypeus and frons. Longer white hairs on the propodeum. Wings hyaline, slightly yellowish with the anterior half of the marginal cell infuscated. Morphology - short longitudinal impression between the antennal sockets; antennae with tyli from Ant 8; S1 without carina; S8 "trident" with lateral points divergent, straight but curving in slightly apically; T7 finely and densly punctate, narrowing towards a rounded apex. Length: 22-32 mm.

Range: Libya (Fezzan, Cyrenaica), Sudan, Eritrea, Egypt, Israel

Distribution: Fayyum (Karanis), Kom Awshim; "ai limiti del coltivato" (Mochi, 1939b)

Flight: males (6-10). "in estate e in autunno" (Mochi, 1939b)

Collections: CGR

ruficornis species group

\section{Stizus combustus (F.Smith, 1856)}

Larra combusta F. Smith, 1856: 341, क; holotype from Trebizond, Turkey (BMNH) [Handlirsch, 1892.]

Larra fuliginosus Klug, 1845: pl. 46, fig. 11, ô; holotype in ZMHU, from Syene (=Aswan), Egypt; junior primary homonym of Larra fuliginosa Dahlbom, 1843 [Handlirsch, 1892; Arnold, 1929.]

Egyptian synonyms:

Stizus fuliginosus

\section{Diagnosis:}

Handirsch, 1892; Storey, 1916; Arnold, 1929; Mochi, 1939c; Honoré, 1942; de Beaumont, 1950c; de Beaumont \& Bytinski-Salz, 1955.

Colour: Black, with the following variable amounts of ferruginous: base of mandible; labrum - may be entirely black; clypeus likewise; frons - usually lateral stripes, but may be entirely ferruginous; antennae - T1 and T13 appear to be constant and the other segments are sometimes ferruginous beneath; temples - a constant narrow line behind the eyes; pronotum - usually ferruginous indicated but may be entirely ferruginous; mesonotum - at most lateral stripes; legs 1 vary from entirely ferruginous to very dark ferruginous; legs 2 underside of femora, tibiae and tarsi ferruginous to black; legs 3 very dark ferruginous at most or black; T1 dark ferruginous or black; T2 rarely ferruginous; S1 \& S2 often ferruginous; other tergites and sternites sometimes show ferruginous traces. Silver appressed pubescence on clypeus and frons. Short brown hair on temples below, pronotum, mesonotum and propodeum, rarely on vertex, never on frons. Wings black (brown seen with transmitted light) with marked hyaline margin right round the wings; veins black.

Morphology: Scutellum with mesal impression (both sexes); mesonotum with parapsidal and admedian lines (not always distinct); propodeum with impressed longitudinal median line; S1 with no carina; first transverse cubital vein (Rs) straight. Males:antennae with tyli on Ant 7-13, not very distinct; Ant 13 curved; T7 with sides sinuate and apex rounded, punctate except apical 
lamella. Length 17-24 mm. Females: metatarsi 1 with 7 spines; tibiae and metatarsi 3 with hair brush on inner side; T6 punctate except apical lamella, rounded. Length: 23-24 mm.

Range: Cent., W \& N Africa, Libya (Tripolitania, Cyrenaica), Egypt, Israel, Oman, Arabia felix Distribution: Deir Gebel el Teir, Fayyum (Karanis 28km W of Shakshuk), Helwan, Kharga Oasis (el Kharga), Kom Awshim, Wadi Digla, Wadi Hagul. "al Fayyum, sui margini del deserto e sulle dune presso al mare, a Port Said" (Mochi, 1939b)

Flight: males (6-11), females (6-7, 10). "in estate e in autunno" (Mochi 1939b)

Collections: CGR

\section{Stizus ruficornis (J.Forster, 1771) ssp. ruficornis (s.s.)}

Vespa ruficornis J. Forster, 1771: 90; holotype from Cadiz, Spain (whereabouts unknown) [Bohart \& Menke, 1976.]

Bembex ruficornis Fabricius, 1787: 286 (nec Forster, 1771). [Handlirsch, 1892.]

Larra pubescens Klug, 1835: 96; type in ZMHU; loc. typ. Spain - Andalusia [Handlirsch, 1892 \& 1895.]

Larra ferrugineus F. Smith, 1856: 342, đ; holotype đom frombia (BMNH). [Handlirsch, 1892; Arnold, 1929.] Synonymised by Guichard, 1989: 157

Stizus Kohlii Mocsáry, 1883: 45, §,શ; syntypes from Syria (TMB) [Handlirsch, 1892.] Synonymised with Stizus ferrugineus by Mochi, 1939: 210

Egyptian synonyms:

Stizus ruficornis Fabricius

Handlirsch, 1892; Honoré, 1942, de Beaumont, 1960a.

Stizus pubescens

Honoré, 1942; de Beaumont, 1950c, 1956a \& 1960a.

Stizus ferrugineus

Handlirsch, 1892; Arnold, 1929; Mochi, 1939c; de

Beaumont \& Bytinski-Salz, 1955.

Stizus kohlii

Stizus ferrugineus var. kohli

Storey, 1916.

Stizus zonatus var. kohli

Mochi, 1939c.

Honoré, 1942.

De Beaumont, 1950c, stated that the Siwa specimens were morphologically identical with ssp.arenarum Handlirsch from Morocco and Algeria, but the coloration was different. There should be a re-examination of the evidence for the conspecificity of ferrugineus v. kohli and zonatus v. kohli with the taxon kohli itself.

Diagnosis: (10 males and 6 females examined.)

Colour: Head: yellow - basal half of mandible (apical half black); labrum; clypeus, sometimes slightly darker at the base; frons either wholly or the lower part only with the upper part being ferruginous; Ant 1 ferruginous - the rest of the head and antennae. Thorax: pronotum, sometimes there is a very narrow yellow along the posterior margin; mesonotum black with broad yellow lateral stripes; tegulae, scutellum and metanotum ferruginous; propodeum ferruginous except the black dorsal area; meso- and metapleurae tend to be ferruginous above and black below, but the amount of each colour is variable, as is its position; legs entirely ferruginous; in some females all three trochanters are black. Abdomen: T1-2 and sometimes the base of T3 is ferruginous; the rest of the tergites are yellow; S1-3 ferruginous; the remainder of the sternites are yellow, sometimes with some basal ferruginous marks. Silver appressed pubescence or pruinescence on the mandibles, clypeus and frons. White hairs on the head and thorax; in some females this is very noticeable and gives a whitish appearance to the naked eye. Hair tufts on femora $2 \& 3$ in males and on tibiae and metatarsi 3 in females, golden in colour. Wings yellowish, especially around the veins; obvious infuscation of the marginal cell and its surrounds; veins brown.

Morphology: Males - antennae with tyli on Ant 5-13, that on Ant 13 is in a different alignment to the remainder; Ant 13 markedly curved; S1 without basal carina; hair brushes on femora 2 and 3; first transverse cubital vein (Rs) straight. Length: 13-21 mm. Females - Ant 3 slightly curved; legs rather short and stocky; metatarsi 1 with 6 spines; hair brushes on tibiae 3 and metatarsi 3; scutellum with mesal impression; T6 rounded with an apical carina, punctate finely; first transverse cubital vein (Rs) straight. Length: 16-24 mm.

Range: Europe, w USSR and Middle East Libya (Tripolitania, Cyrenaica), Africa from Cape to Egypt, Israel, Syria, Oman

Distribution: Siwa Oasis, Fayyum (Karanis, 28 km W of Shakshuk), Helwan, Kom Awshim, Marg, Minia "sui margini del deserto e sopratutto al Fayum" (Mochi, 1939b)

Flight: males $(5,8-11)$, females $(6,10)$. "in estate e in autunno" (Mochi, 1939b) 
Collections: CGR

\section{Stizus ruficornis (J.Forster, 1771) ssp. strigatus Mochi, 1939}

Stizus strigatus Mochi, 1939: 211, §̊,, ; type from Sollum (PPDD); reduced to ssp by de Beaumont, 1960a: 236

Egyptian synonyms:

Stizus strigatus

Stizus ruficornis strigatus

Mochi, 1939c; Honoré, 1942.

Range: Egypt

Distribution: Sollum

Collections: PPDD (Mochi, 1939b)

\section{Stizus spinulosus Radoszkowski, 1876}

Stizus spinulosus Radoszkowsi, 1876: 186,, ; holotype $q$ in ZMJU, from 'Egypt'. [Handlirsch, 1892.]

Egyptian synonyms: Stizus spinulosus

Roth, 1934; Mochi, 1939c; Honoré, 1942; Bohart

Range: Libya (Tripolitania), Egypt \& Menke, 1976.

Distribution: "Nelle zone desertiche dei dintorni del Cairo" (Mochi 1939b)

Flight: "sopratutto in primavera e al principio dell'estate" (Mochi, 1939b)

unknown species groups

\section{Stizus annulatus (Klug, 1845)}

Larra annulata Klug, 1845: pl. 46, fig. 7, ô; holotype ${ }^{\wedge}$ in ZMHU, from Syria. [Handlirsch, 1892.] Larra subapicalis Walker, 1871: 35, ; ; syntype $ᄋ$ destroyed, from Wadi Feiran, Sinai. [Handlirsch, 1892.]

Egyptian synonyms:

Larra subapicalis

Larra annulata Walker

Innes, 1911.

Stizus annulatus

Innes, 1911.

Range: Eurasia, n. Africa, Middle East

Honoré, 1942, fide Handlirsch.

\section{Stizus basalis Guérin-Méneville, 1844}

Stizoides basalis Guérin-Méneville, 1844: 438, ๑; syntype $\odot$ in MSNG, from Senegal. [Handlirsch, 1892; Arnold, 1929.]

Egyptian synonyms:

Stizus basalis

Handlirsch, 1892; Arnold, 1929; Honoré, 1942,

Range: N \& NW Africa

\section{Stizus elegans Dahlbom, 1845}

Stizus elegans Dahlbom, 1845: 478, ${ }^{\top}$; syntype ${ }^{\lambda}$ in NRS, from 'Egypt'. [Handlirsch, 1892.]

Egyptian synonyms:

Stizus elegans

fide Handlirsch.

Range: Egypt

\section{Stizus fuscatus Morice, 1897}

Stizus fuscatus, Morice, 1897a: 312, pl. VI, figs. 28 \& 29, ô; holotype in OUM; loc. typ. Egypt Cairo.

Stizus anchorites Turner, 1920: 269, o ; holotype $\delta^{\lambda}$ in PPDD, from Maasara $10 \mathrm{~km} \mathrm{~S}$ of Cairo in the Eastern Desert. Synonymized by Guichard 1989: 156.

Stizus storeyi Turner, 1920: 269, $\delta^{\dagger}$; holotype ${ }^{\lambda}$ in BMNH, from Saqqara, Egypt. Synonymized by Guichard 1989: 156.

Egyptian synonyms: 
Stizus anchorites

Stizus fuscatus

Stizus storeyi

Stizus Storeyi

Range: Morocco, Algeria, Libya (Fezzan), Egypt, Israel

\section{Stizus pictus Dahlbom, 1845}

Stizus pictus Dahlbom, 1845: 478,, ; holotype $q$ in NRS, from 'Egypt'. [Handlirsch, 1892.]

Egyptian synonyms:

Stizus pictus

Bohart \& Menke, 1976.

Range: Egypt

\section{Stizus rapax Handlirsch, 1892}

Stizus rapax Handlirsch, 1892: 157, 9 ; holotype $\odot$ in NHMW, from 'Egypt'

\section{Egyptian synonyms:}

Stizus rapax

Storey, 1916; Honoré, 1942, fide Handlirsch; de Beaumont, 1950c; Bohart \& Menke, 1976; Guichard, 1989b.

De Beaumont, 1950c, had some doubts about his determination. Handlirsch, 1892, was not certain that the $\hat{\sigma}$ of his pubescens belonged to that species, but his meaning is not clear. De Beaumont considers that the Siwa $\bar{\partial} \delta$ that he determined with doubt as those of rapax are morphologically similar but of a different coloration. Guichard, 1989b, commented that "some of the Egyptian species of Stizus may occur in Arabia, but the status of ... S. rapax Handlirsch ... is obscure." - his meaning is not known.

\section{Stizus rufiventris Radoszkowski, 1877 ssp. compar Handlirsch, 1892}

Stizus rufiventris Radoszkowski, 1877: 36, pl. 4, fig. 11, §,, ; syntypes in ZMMU, from Samarkand. [Handlirsch, 1892.]

Stizus compar Handlirsch, 1892: 118, $q$; holotype $q$ in NHMW, from Tiflis (Tblisi), Georgia

Egyptian synonyms:

Stizus rufiventris compar Bohart \& Menke, 1976.

Range: Egypt, Iran

\section{Stizus rufocinctus Dahlbom, 1845}

Stizus rufocinctus Dahlbom, 1845: 478, ð̊; holotype đ̊ in NRS, from 'Egypt'. [Handlirsch, 1892.]

Egyptian synonyms:

Stizus rufocinctus

Bohart \& Menke, 1976.

Range: Egypt

\section{Stizus schmiedeknechti Handlirsch, 1898}

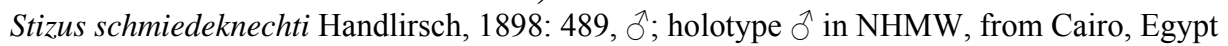

Egyptian synonyms:

Stizus schmiedeknechti Honoré, 1942; Bohart \& Menke, 1976.

Range: Egypt

\section{Stizus tricolor Handlirsch, 1892}

Stizus tricolor Handlirsch, 1892: 133-134, o̊; syntypes in MHNG, from Syria \& Cyprus

Egyptian synonyms:

Stizus tricolor

Handlirsch, 1892; Guichard, 1989b.

Range: Sudan, Tunisia, Iran, Cyprus, Syria, Turkey, Egypt

Distribution: Faiyum 


\section{Stizus tunetanus A. Costa, 1893}

Stizus tunetanus Costa, 1893a \& b, ơं holotype ô in Naples, from Tunisia [Handlirsch, 1895.]

Egyptian synonyms:

Stizus tunetanus

Guichard, 1989b.

Guichard, 1989b, commented that "some of the Egyptian species of Stizus may occur in Arabia, but the status of $S$. tunetanus Costa ... is obscure." - his meaning is not known.

\section{Stizus zonatus (Klug, 1845)}

Larra zonatus Klug, 1845: pl. 46, fig. 2,, , holotype in ZMHU, from "Arabia felix", now Saudi Arabia. [Handlirsch, 1892.]

Egyptian synonyms:

Stizus zonatus Handlirsch, 1892; Honoré, 1942.

Handlirsch, 1895, synonymised ferrugineus Smith with this species. This has not been recognised by Bohart \& Menke, 1976.

Larra zonata

Innes, 1911 from a Walker label.

Range: $n$. Africa

Distribution: Sinai

\section{Stizus zonosoma Handlirsch, 1895}

Stizus zonosoma Handlirsch, 1895: 993, ठ̊ં; holotype $\widehat{\partial}$ in NHMW, from 'Egypt'

Egyptian synonyms:

Stizus zonosoma

Honoré, 1942; Bohart \& Menke, 1976.

Range: Egypt

\section{PHILANTHINAE}

Philanthini

Philanthus Fabricius, 1790

triangulum species group

\section{Philanthus triangulum (Fabricius, 1775) ssp. abdelcader Lepeletier}

[Philanthus] triangulum Fabricius, 1775: 373; holotype $\$$ from Copehagen, Denmark (ZMK) Philanthus Abdelcader Lepeletier, 1845: 33-34, pl.25, fig.2, วิ, + ; type from Oran, Algeria (MNHN?)

\section{Egyptian synonyms:}

Philanthus Abd el Kader S. et F. Innes, 1911. Presumably Innes "S. et F." refers to Lepeletier de St. Fargeau.

Philanthus diadema Fabricius, $1781 \quad$ Innes, 1911, quoting from the labels of specimens determined by the regrettable F. Walker. This name is that of another subspecies of $P$. triangulum, but from the Ethiopian region. This does not equate with the locality given of Cairo, and it must remain one of Walker's mysteries

Philanthus triangulum Storey, 1916 (without mention of subspecies).

Philanthus triangulum var. Abdelcader F. (lapsus) Mochi, 1939b.

Philanthus triangulum var. Abd-el-Kader Honoré, 1942.

Philanthus triangulum abdelcader

Osborn \& Krombein, 1969; Krombein, 1969;

Guichard, 1980; Simonthomas \& Simonthomas, 1980, Piek, 1986.

Philanthus triangulum abdelkader (sic) de Beaumont, 1966; de Beaumont \& BytinskiSalz, 1959.

Philanthus triangulum abdelkader Luc. (sic) Sayed et al, 1964.

Range: Morocco, Algeria, Libya (Tripolitania, Cyrenaica), Egypt, Oman

Distribution: Abu Rawash, Abu Sir, Dakhla Oasis (Tineida), Fayyum (Hawarah, Karanis, Kom el Atl), Gebel el Asfar, Helwan, Ismailia, Kerdasa, Kom Awshim, el Minia, Saqqara. Sinai - Rafah Flight: males $(1-10,12)$, females $(2-7,9)$ 
Collections: CGR

Philanthus triangulum (Fabricius, 1775) ssp. obliteratus Pic, 1917

Philanthus obliteratus Pic, 1917: 2; syntypes from Algeria \& Egypt (MNHN?)

Egyptian synonyms:

Philanthus triangulum obliteratus Bohart \& Menke, 1976; Gayubo, 1991.

Range: Algeria, Egypt

genalis species group

Philanthus genalis Kohl, 1891

Philanthus genalis Kohl, 1891: 349, ð,ๆ; syntypes from Tor, Sinai (NHMW) \& Libyan desert (ZMHU)

Egyptian synonyms:

Philanthus genalis Mochi, 1939b; Honoré, 1942; de Beaumont,

Range: Libya (Tripolitania, Fezzan), Egypt, Sinai

Distribution: Fayyum (El Khawagat), Kerdasa, Wadi Digla. Sinai - Hamamat Faraoun

Flight: males (3-4), females (4-5). According to Mochi (1939a) from February to October

Collections: CGR

rutilus species group

Philanthus rutilus Spinola, 1839

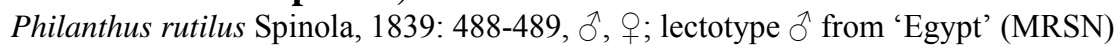

Egyptian synonyms:

Philanthus rutilans (lapsus) Storey, 1916.

Philanthus rutilus

Mochi, 1939b; Honoré, 1942.

Philanthus rutilus rutilus $\quad$ de Beaumont, 1949a, 1956a, 1960a \& 1961a;

Bohart \& Menke, 1976.

Range: Algeria, Libya (Fezzan, Cyrenaica), Chad (Tibesti), Egypt

Distribution: Ben Yussef, Kafr Faruk

Flight: males (2), females (3). According to Mochi (1939a) it also occurs in April

Collections: CGR

coarctatus species group

\section{Philanthus coarctatus Spinola, 1839}

Philanthus coarctatus, Spinola, 1839: 486-488; $\hat{\jmath}$, + ; lectotype $\widehat{\jmath}$ from Egypt (MRSN). Guiglia, 1939.

Philanthus Niloticus F. Smith, 1873: 415, , type from White Nile, Sudan (BMNH) [de Beaumont, 1949a.]

Egyptian synonyms:

Philanthus coarctatus

Storey, 1916; Guiglia, 1939; Mochi, 1939b; Honoré, 1942; de Beaumont, 1949a \& 1961a; de Beaumont \& Bytinski-Salz, 1959; Pulawski, 1964; de Beaumont, 1967b; Osborn \& Krombein, 1969. The record of Osborne \& Krombein, 1969, is from Gebel 'Uweinat, but from the Sudanese part. Philanthus niloticus Storey, 1916; Mochi, 1939b; Honoré, 1942.

Range: Spanish Sahara, Morocco, Libya (Tripolitania, Fezzan), Chad (Tibesti), Sudan (Gebel 'Uweinat, Wadi Halfa), Egypt, Israel, Syria, Turkey, Arabia, Oman, Transcaspia

Distribution: Aswan, Fayyid, Fayyum (3km NW of Qasr Qarun), Gebel el Asfar, Giza (Pyramids), Helwan, Kabrit, Kerdasa, Kom Awshim, Kom Ombo, Luxor, Manqabad, Wadi Digla, Wadi el Natrun, Wadi er Rayan, Km20 Zafarana road. Sinai - Hamamat Faraoun, Rafah, Umm Bugma

Flight: males (1-10), females (2-12)

Collections: CGR, WJP 
Philanthus minor Kohl, 1891

Philanthus minor Kohl, 1891: 358, $q$; holotype $q$ from 'Egypt' (ZMHU)

Egyptian synonyms:

Philanthus minor

Mochi, 1939b; Honoré, 1942; de Beaumont, 1949a.

Range: Algeria, Egypt

Distribution: Dahshur, Mersa Matruh

Flight: males (6,8), females (6). According to Mochi (1939a) it occurs in March

Collections: CGR

\section{Philanthus pallidus Klug, 1845}

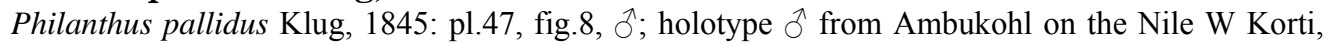
Sudan (ZMHU) [de Beaumont, 1949a.]

Egyptian synonyms: Philanthus pallidus

Arnold, 1925; Mochi, 1939b; Honoré, 1942; de Beaumont, 1949a \& 1956a; de Beaumont \& Bytinski-Salz, 1959; Bohart \& Menke, 1976.

Range: Mauritania, Spanish Sahara, Algeria, Egypt, Israel, Ethiopia, Oman

Distribution: Kerdasa, Kom Awshim

Flight: males (9), females (10). According to Mochi (1939a) it occurs from May to July

Collections: CGR

\section{Philanthus venustus (Rossi, 1790)}

Crabro venustus Rossi, 1790: 94; holotype from Toscana, Italy (destroyed).

Philanthus melliniformis F. Smith, 1856: 469, §̋; holotype $\precsim$ from Sicilia, Italy (BMNH)

Egyptian synonyms:

Philanthus melliniformis

Innes, 1911.

Innes is citing one of Walker's labels with this synonym of venustus. The localities are given as Sinai and Tadjourah. The species has not otherwise been recorded from Egypt. It is known from Israel so that it is possibly a correct record, but is best regarded with a certain doubt until otherwise confirmed.

coronatus species group

\section{Philanthus variegatus Spinola, 1839 ssp. variegatus (s.s.)}

Philanthus variegatus, Spinola, 1839: 484-485, $\hat{O}$,,+ , lectotype from 'Egypt' (MRSN).

Philanthus distinguendus Kohl, 1891: 361, ô'; syntype $\widehat{O}$ from 'Egypt' (NHMW). Synonymised with variegatus by de Beaumont, 1949: 183

\section{Egyptian synonyms:}

Philanthus variegatus

Philanthus variegatus variegatus Philanthus distinguendus Kohl, 1891

Range: Egypt, Israel

Distribution: Gebel el Asfar

Flight: males (5). According to Mochi (1939a) it occurs from March to June

Collections: CGR
Mochi, 1939b; Honoré, 1942; de Beaumont \& Bytinski-Salz, 1959; de Beaumont, 1961a; Bohart \& Menke, 1976.

de Beaumont, 1949a.

Honoré, 1942. 
Aphilanthopsini

Philanthinus de Beaumont, 1949

Philanthinus integer (de Beaumont, 1949)

Philoponus sp. Morice, 1911: 94, corrected de Beaumont, 1949: 194

Philanthus (Philanthinus) integer de Beaumont, 1949a: 194-197, ô,,+ , type from Algeria Tadjerouna (BMNH).

Egyptian synonyms:

Philanthinus integer

Range: Morocco, Algeria, Egypt, Israel

de Beaumont, 1961a; Bohart \& Menke, 1976.

Pseudoscoliini

Pseudoscolia Radoszkowski, 1876

theryi species group

Pseudoscolia pharaonum (Kohl, 1898)

Philoponus pharaonum Kohl, 1898: 96, + ; holotype $q$ from Cairo area, Egypt (NHMW)

Egyptian synonyms:

Philanthus (Philoponus) pharaonum Mochi, $1939 \mathrm{~b}$.

Philoponidea Pharaonum Honoré, 1942.

Philoponidea pharaonum de Beaumont, 1949a.

Pseudoscolia pharaonum Pulawski, 1964; Bohart \& Menke, 1976.

Range: Egypt

Distribution: Abu Rawash, Gebel el Asfar, Saqqara

Flight: males (3-4), females (3-5)

Collections: WJP

Pseudoscolia sp. ? nov.

Egyptian synonyms:

In coll CGR, from Wadi Natrun there is a $\hat{o}$ of the theryi species group which does not agree with any of the described species.

Range: Egypt

Distribution: Wadi el Natrun

Flight: males (2)

Collections: CGR

dewitzii species group

\section{Pseudoscolia berlandi (de Beaumont, 1949)}

Pseudoscolia berlandi de Beaumont, 1949a: 209-210, Ô, , , type in MNHN, loc. typ. Algeria - Sidi Obka.

Egyptian synonyms:

Pseudoscolia berlandi

de Beaumont \& Bytinski-Salz, 1959; Bohart \&

Range: Algeria, Egypt, Israel

Menke, 1976.

Collections: BMNH, MNHN

Pseudoscolia dewitzii (Kohl, 1889)

Philoponus Dewitzii Kohl, 1889: 195, ổ, loc. typ. Egypt (ZMHU).[de Beaumont, 1949a.]

Egyptian synonyms:

Philanthus (Philoponus) Dewitzii

Philoponidea Dewitzi

Mochi, 1939b.

Honoré, 1942. 
Philoponidea dewitzii Pseudoscolia dewitzi de Beaumont, 1949a.

de Beaumont \& Bytinski-Salz, 1959; de Beaumont, 1958d; Pulawski, 1964; de Beaumont, 1966.

Range: Canary Is., Morocco, Algeria, Tunisia, Libya (Tripolitania, Fezzan), Egypt, Israel, Oman Distribution: Abu Rawash, Dahshur, Fayyum (3km NW of Qasr Qarun), Giza, Kerdasa, Kom Awshim, Kom Ombo, Maadi, Mersa Matruh, Saqqara, Wadi Digla

Flight: males (2-5), females $(2-6,8)$

Collections: CGR, WJP EIZ, NRS, BMNH, MNHN

\section{Pseudoscolia sinaitica (Mochi, 1939)}

Philanthus (Philoponus) sinaitica Mochi, 1939b: 111-112; + ; holotype $q$ in AM; loc.typ. Egypt - Sinai, Wadi Umm Mitla.

Egyptian synonyms:

Philanthus (Philoponus) sinaitica Mochi, 1939b.

Philoponidea sinaïtica Honoré, 1942.

Philoponidea sinaitica de Beaumont, 1949a.

Pseudoscolia sinaitica de Beaumont \& Bytinski-Salz, 1959; Bohart \&

Range: Sinai, Israel

Distribution: Sinai - Wadi Umm Mitla

Flight: females (5)

\section{Pseudoscolia soikae (Mochi, 1939)}

Philanthus (Philoponus) Soikae Mochi, 1939b; + ; holotype $q$ in AM; loc. typ. Egypt - Sinai, Wadi Umm Mitla.

Egyptian synonyms:

Philanthus (Philoponus) Soikae

Philoponidea Soïkae

Menke, 1976.
Mochi, $1939 b$

Honoré, 1942.

de Beaumont, 1949a.

Bohart \& Menke, 1976.

Range: Egypt

Distribution: Sinai - Wadi Umm Mitla

Flight: females (4)

Collections: AM

\section{Pseudoscolia spinulicollis (Mochi, 1939)}

Philanthus (Philoponus) spinulicollis Mochi, 1939b: 108-109; 9 ; holotype $q$ in AM; loc. typ. Egypt - Wadi Abu Rawash.

Egyptian synonyms:

Philanthus (Philoponus) spinulicollis

Philoponidea spinulicollis

Pseudoscolia spinulicollis

Mochi, 1939b.

Honoré, 1942; de Beaumont, 1949a.

Pulawski, 1964; Bohart \& Menke, 1976.

Range: Egypt

Distribution: Abu Rawash, Kom Awshim. Sinai - Wadi Umm Mitla

Flight: males (4), females (4-5)

Collections: WJP

espanoli species group

\section{Pseudoscolia efflatouni (Mochi, 1939)}

Philanthus (Philoponus) Efflatouni Mochi, 1939b: 106-108; $q$; holotype $q$ in AM; loc. typ. Egypt Sinai, Wadi Umm Mitla.

Egyptian synonyms:

Philanthus (Philoponus) Efflatouni Mochi, 1939b.

Philoponidea Efflatouni

Philoponidea efflatouni

Honoré, 1942.

Pseudoscolia efflatouni 


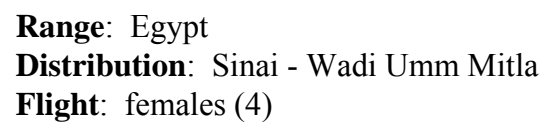

\section{Cercerini}

Cerceris Latreille, 1802-1803

In no case did Mochi, 1939a, designate which sex was the holotype. He gave localities and dates for the "type" of each sex. De Beaumont, 1951b, designated the first described sex as the holotype. He also said the holotypes were in Cairo. They were in coll. Mochi, but these specimens were amongst those which after the war Alfieri sold to the Smithsonian and therefore the location of them should be USNM.

rybyensis species group

\section{Cerceris albicincta Klug, 1845}

Cerceris albicincta Klug, 1845, pl.47, fig.10, §‡; holotype $ð$ in ZMHU; loc. typ. Nubia Ambukohl. [de Beaumont, 1951b.]

Egyptian synonyms:

Cerceris albicincta

Storey, 1916; de Beaumont, 1951a; de Beaumont

Cerceris (s.s.) albicincta \& Bytinski-Salz, 1959.

Giner Marí, 1941b (fide Klug \& Schletterer); Honoré, 1942.

\section{Cerceris berenice de Beaumont, 1966}

Cerceris berenice de Beaumont, 1966: 206-208, $\curvearrowright, \propto$; holotype + in MZL; loc. typ. Egypt - Gebel Elba.

Egyptian synonyms:

Cerceris berenice $\quad$ de Beaumont, 1966; Bohart \& Menke, 1976.

\section{Cerceris cheops de Beaumont, 1951}

Cerceris pulchella Klug sensu Mochi, 1939a: 175. [de Beaumont, 1951b \& 1951d.]

Cerceris cheops de Beaumont, 1951a: 179, ô,,+ ; holotype $\bigcirc$ in coll. de Beaumont in MZL; loc. typ. Algeria - Biskra.

Egyptian synonyms:

Cerceris pulchella Mochi, 1939a.

Cerceris cheops de Beaumont, 1951a \& 1951b; de Beaumont \&

Bytinski-Salz, 1959; Pulawski, 1964.

\section{Cerceris clytia de Beaumont, 1959}

Cerceris clytia de Beaumont in de Beaumont \& Bytinski-Salz, 1959: 116-118, $\partial^{\lambda}, \propto$; holotype $\odot$ in coll. de Beaumont in MZL; loc typ. Israel - Beersheba.

Egyptian synonyms:

In coll CGR. The first record from Egypt.

\section{Cerceris fimbriata (Rossi, 1790) ssp. fimbriata (s.s.)}

Crabro fimbriatus Rossi, 1790: 93; loc. typ. Toscana, Italy (destroyed). [de Beaumont, 1951b.]

Egyptian synonyms:

Cerceris fimbriata de Beaumont, 1951b; de Beaumont \& BytinskiSalz, 1959; Bohart \& Menke, 1976.

\section{Cerceris fischeri Spinola, 1839}

Cerceris Fischeri Spinola, 1839: 493-495, §̊,, ; type in MRSN; loc. typ. Egypt. [de Beaumont, 1951b; Empey, 1973; Pulawski, 1983.]

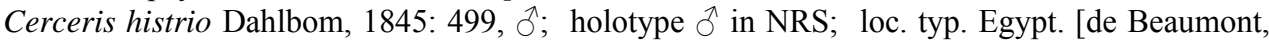
1951b.] 
?Cerceris contigua, Walker, 1871 28; type lost; loc. typ. Egypt - Sinai.[de Beaumont, 1951b.] This is considered to be a junior synonym of fischeri but the name is, in any case, a junior homonym of contigua Villers, 1789.

\section{Egyptian synonyms:}

Cerceris contigua

Cerceris Fischeri

Cerceris (Apiraptryx) fischeri

Cerceris (Apiraptrix) Fischeri

Innes, 1911.

Mochi, 1939a; Honoré, 1941a.

Cerceris fischeri

Giner Marí, 1941b.

Honoré, 1942.

de Beaumont, 1950c, 1951a, 1951b \& 1951d;

Pulawski, 1964; de Beaumont, 1966; Pulawski, 1983.

\section{Cerceris histrionica Klug, 1845}

Cerceris histrionica Klug, 1845, pl.47, fig.9, đ (nec + ); holotype $\lesssim$ in ZMHU; loc. typ. Saqqara \& Faiyum, Egypt. [de Beaumont, 1951b.] Cerceris Honorei nov. spec., Mochi, 1939a: 186-187, $q$; holotype $q$ in Cairo (?USNM); loc. typ. Egypt - Gebel Asfar. De Beaumont, 1951d, synonymised this species with histrionica.

Egyptian synonyms:

Cerceris histrionica

Cerceris Honorei

Cerceris (Apiraptryx) histrionica

Cerceris (Apiraptrix) histrionica

Cerceris (Apiraptryx) honorei

Cerceris (Apiraptrix) Honorei
Innes, 1911; Honoré, 1942; de Beaumont, 1951a \& 1951b; de Beaumont \& Bytinski-Salz, 1959; Bohart \& Menke, 1976.

Mochi, 1939a; Honoré, 1941a.

Giner Marí, 1941b.

Honoré, 1942.

Giner Marí, 1941b.

Honoré, 1942.

Range: Morocco, Algeria, Libya, Egypt, Israel

Distribution: Saqqara, Faiyum, Wadi Feiran, Wadi Gennah, Mt Sinai

\section{Cerceris klugii F. Smith, 1856}

Cerceris annulata Klug, 1845:[29], pl.47, fig. 5, §, nec C.annulata Rossi; holotype đo from Faiyum, Egypt (ZMHU) [Giner Marí, 1941b.]

Cerceris klugii nom. nov. for annulata, F. Smith, 1856: 445. [de Beaumont, 1951b.]

Cerceris klugii Schletterer, 1887: 395, ô,, ; junior primary homonym and unjustified new name [Giner Marí, 1941b.]

Egyptian synonyms:

Cerceris klugi Schletterer

Cerceris Klugi Schletterer

Storey, 1916.

Cerceris klugii F. Smith

Honoré, 1941a.

Cerceris (Apiraptryx) klugii Schletterer

Mochi, 1938; de Beaumont, 1951a \& 1951b;

Bohart \& Menke, 1976.

Cerceris (Apiratrix) Klugi Schletterer

Giner Marí, 1941b, fide Klug \& Schletterer.

Honoré, 1942.

\section{Cerceris lunata A. Costa, 1869}

Cerceris lunata, A. Costa, 1869: 106,, ; holotype $\widehat{\delta}$ [sic] in Naples; loc. typ. Italy. [Giner Marí, 1941a; de Beaumont, 1951b; Pulawski, 1965b.]

Egyptian synonyms: [??]

Collections: the evidence that it occurs in Egypt is unknown

\section{Cerceris luxuriosa Dahlbom, 1845}

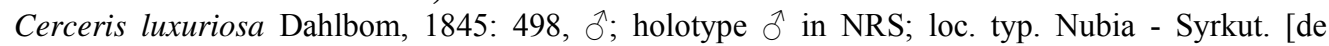
Beaumont, 1951b.]

Cerceris subimpressa Schletterer, 1887, Ô,o; holotype in NHMW; loc. typ. Egypt. [de Beaumont, 1951b.] de Beaumont, 1950d, synonymised subimpressa with luxuriosa.

Egyptian synonyms:

Cerceris (Apiraptryx) subimpressa Giner Marí, 1941b, fide Schletterer.

Cerceris subimpressa

Honoré, 1941a.

Cerceris (Apiraptrix) subimpressa

Honoré, 1942. 
Cerceris pallidula Morice, 1897 ssp. pallidula (s.s.)

Cerceris pallidula Morice, 1897a: 302, đิ, , ; holotype in OUM; loc. typ. Egypt - Abbasieh. Egyptian synonyms:

Cerceris pallidula

Cerceris (Apiraptryx) pallidula

Cerceris (Apiraptrix) pallidula

Morice, 1897a \& 1911; Storey, 1916; Mochi, 1939a; Honoré, 1941a; de Beaumont, 1951b; de Beaumont \& Bytinski-Salz, 1959.

Cerceris pallidula pallidula

Giner Marí, 1941b.

Honoré, 1942.

Pulawski, 1964; Bohart \& Menke, 1976.

\section{Cerceris priesneri Mochi, 1939}

Cerceris pulchella Schletterer, 1887: 391, nec Klug, 1845.

Cerceris Priesneri Mochi, 1939a: 179-180, figs., ${ }^{\uparrow}, \uparrow$; holotype in Cairo, now USNM; loc. typ. Egypt - Abu Rawash.

Egyptian synonyms:

Cerceris Priesneri

Cerceris (Apiraptryx) priesneri

Cerceris (Apiraptrix) Priesneri

Mochi, 1939a.

Cerceris priesneri

Giner Marí, 1941b \& 1947.

Honoré, 1942.

de Beaumont, 1951a \& 1951b.

\section{Cerceris pruinosa Morice, 1897}

Cerceris pruinosa Morice, 1897a: 303, pl.6, fig.2, + ; holotype $q$ in OUM; loc. typ. Egypt Abbasieh.

Egyptian synonyms:

Cerceris pruinosa

Cerceris (Apiratryx) pruinosa

Cerceris (Apiratrix) pruinosa

Morice, 1897a \& 1911; Mochi, 1939a; Honoré, 1941a; de Beaumont, 1951b; de Beaumont \& Bytinski-Salz, 1959.

Giner Marí, 1941b.

Honoré, 1942.

\section{Cerceris pulchella Klug, 1845 ssp. pulchella (s.s.)}

Cerceris pulchella Klug, 1845, pl. 47, fig.14, ô; holotype ${ }^{\dagger}$ in ZMHU; loc. typ. Egypt - Fayoum. [de Beaumont, 1951b.]

Cerceris Alfierii Mochi, 1939a: 181-183, figs., Ô, of; holotype in Cairo (?USNM); loc. typ. Egypt - Mansurieh \& Gebel Asfar. De Beaumont, 1951d, synonymised this species with pulchella.

Cerceris Alfierii var. picta Mochi, 1939a: 182-183, ô,o (nec Dahlbom, 1844); holotype in Cairo (?USNM); loc. typ. Egypt - Saqqara \& Kerdasa. This variety was not considered by de Beaumont, 1951d, to be worthy of conservation as a name.

Egyptian synonyms:

Cerceris pulchella

Cerceris Alfierii

Cerceris (Apiraptryx) pulchella

Cerceris (Apiraptrix) pulchella

Cerceris (Apiraptryx) alfierii

Cerceris (Apiraptrix) Alfierii

Cerceris alfierii

Cerceris Alfierii var. picta

Cerceris (Apiraptryx) alfierii var. picta

Cerceris (Apiraptrix) Alfierii var. picta

Cerceris alfierii var. picta
Innes, 1911; Storey, 1916; Honoré, 1941a; de Beaumont, 1951a \& 1951b; de Beaumont \& Bytinski-Salz, 1959; Pulawski, 1964; de Beaumont, 1966; Bohart \& Menke, 1976.

Mochi, 1938.

Giner Marí, 1941b.

Honoré, 1942.

Giner Marí, 1941b.

Honoré, 1942.

de Beaumont, 1951a.

Mochi, 1938.

Giner Marí, 1941b.

Honoré, 1942.

de Beaumont, 1951a. 


\section{Cerceris rybyensis (Linnaeus, 1771)}

Sphex Rybyensis Linnaeus, 1771: 8; lectotype \%; loc. typ. Sweden. [de Beaumont, 1951b; Pulawski, 1965b.]

Egyptian synonyms: [??]

Collections: the evidence that it occurs in Egypt is unknown

\section{Cerceris sabulosa (Panzer, 1799) ssp. algirica (Thunberg, 1815)}

Philanthus sabulosus, Panzer, 1799: 63. [Pulawski, 1965b.]

Philanthus algiricus Thunberg, 1815: 136, + ; holotype + in UZIU; loc. typ. "Barbaria", now Algeria. [de Beaumont, 1951b.]

Egyptian synonyms: [??]

\section{bupresticida species group}

\section{Cerceris bupresticida Dufour, 1841 ssp. libyca de Beaumont, 1960}

Cerceris bupresticida Dufour, 1841: 353, pl. 11a, figs. 1-6, ô, , ; type in MNHN; loc. typ. France St. Sever. [de Beaumont, 1951b.]

Cerceris bupresticida libyca de Beaumont, 1960a: 232-233, + ; holotype $\odot$ in BMNH; loc. typ. Libya - Cyrenaica, Beris.

Egyptian synonyms:

Cerceris bupresticida

de Beaumont, 1950a, 1951b \& 1956a.

Range: Libya (Tripolitania, Cyrenaica), Egypt

Distribution: Siwa Oasis

\section{Cerceris hathor Pulawski, 1983}

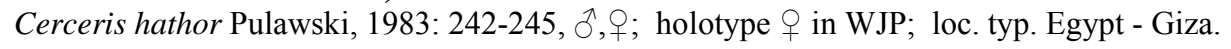

Egyptian synonyms:

Cerceris vidua Klug

Cerceris (s.s.) vidua

Innes, 1911; Honoré, 1941a.

Honoré, 1942. This is a misidentification. C. vidua Klug is a junior synonym of $C$. tricolorata

Cerceris tricolorata Spinola Spinola.

Cerceris (Apiraptryx) tricolorata

Mochi, 1939a.

Cerceris (Apiraptrix) tricolorata

Giner Marí, 1941b.

Cerceris eugenia

Honoré, 1942. misidentification.

de Beaumont, 1951b \& 1958d; de Beaumont \& Bytinski-Salz, 1959; Pulawski, 1964.

Cerceris hathor misidentification.

For full details of the vidua, tricolorata, eugenia muddle, see Pulawski, 1983.

Range: Egypt

Distribution: Dakhla Oasis (Al Qasr), Giza, Kom Awshim, Wadi Digla, 40Km Zafarana road

Flight: males (4-5), females (4-5)

Collections: WJP

\section{Cerceris palmetorum de Beaumont, 1951}

Cerceris palmetorum de Beaumont, 1950: 8, $\widehat{\partial}$,, ; holotype $\rho$ in BMNH; loc. typ. Egypt - Siwa Oasis. [The World Catalogue has this as a nomen nudum because de Beamont did not describe it until 1951b: 342-345]

Egyptian synonyms:

Cerceris palmetorum

de Beaumont, 1950c \& 1951b.

Range: Egypt

Distribution: Siwa 


\title{
Cerceris tricolorata Spinola, 1839
}

Cerceris tricolorata Spinola, 1839: 493, + ; holotype $\odot$ in MRSN; loc. typ. Egypt. [de Beaumont, 1951b.]

Cerceris insignis Klug, 1845, o ; holotype from Saudi Arabia (ZMHU)

Cerceris vidua Klug, 1845, ô; holotype $\widehat{o}$ from Saudi Arabia (ZMHU)

De Beaumont, 1951d, synonymised the two Klug species, which are opposite sexes of the same species, with tricolorata.

Egyptian synonyms:

Cerceris vidua

Cerceris alboatra Walker

Cerceris albo-atra

Cerceris insignis

Cerceris (s.s.) insignis

Cerceris (s.s.) albo-atra

Cerceris (s.s.) eugenia Schletterer

Cerceris tricolorata

\author{
Morice, 1897a (per de Beaumont, 1951b). \\ Mochi, 1939a, misidentification. \\ Honoré, 1941a, misidentification. \\ Honoré, 1941a. \\ Honoré, 1942. \\ Honoré, 1942. \\ Giner Marí, 1941b; Honoré, 1942. \\ de Beaumont, 1951a \& 1951b; de Beaumont \& \\ Bytinski-Salz, 1959; Pulawski, 1964; Bohart \& \\ Menke, 1976.
}

Range: Spanish Sahara, Algeria, Libya (Tripolitania), Chad (Tibesti), Egypt, Israel, Palestine, central Asia, Saudi Arabia, Oman

Distribution: Kom Awshim, El Minia

Flight: males (4-5), females (5)

Collections: CGR, WJP

alboatra species group

\section{Cerceris alboatra Walker, 1871}

Cerceris alboatra Walker, 1871: 27, ふึ; type lost; loc. typ. Egypt - Sinai, Wadi Feiran. [de Beaumont, 1951b.]

Egyptian synonyms:

Cerceris alboatra Innes, 1911; de Beaumont, 1951b; de Beaumont \& Bytinski-Salz, 1959; Bohart \& Menke, 1976; Guichard, 1993.

\section{arenaria species group}

\section{Cerceris rutila Spinola, 1839 ssp. rutila (s.s.)}

Cerceris rutila Spinola, 1839: 492-493, + ; holotype in MRSN; loc. typ. Egypt. [de Beaumont, 1951b.]

Cerceris excellens Klug, 1845, pl.47, fig. 15, ${ }^{\lambda}$; holotype ${ }^{\lambda}$ in ZMHU; loc. typ. Egypt Saqqara. [de Beaumont, 1951b.] Honoré, 1941a, recognised that this was the of of rutila. Cerceris rubecula Schletterer, 1889: 899, + ; holotype $q$ in NHMW; loc. typ. Egypt - Cairo. [de Beaumont, 1951b.] Kohl, 1915, recognised the synonymy of rubecula with rutila.

Egyptian synonyms:

Cerceris excellens Walker (sic)

Cerceris excellens

Innes, 1911.

Cerceris rutila

Storey, 1916.

Mochi, 1939a; Honoré, 1941a; de Beaumont, 1951a, 1951b, 1951d \& 1956a; de Beaumont \& Cerceris (s.s.) rutila Bytinski-Salz, 1959; Bohart \& Menke, 1976.

Range: Tunisia, Libya (Tripolitania, Cyrenaica), Egypt

Distribution: Wadi el Natrun

Flight: males (3)

Collections: CGR 


\section{Cerceris quadricincta (Panzer, 1799) ssp. quadricincta (s.s.)}

Cerceris quadricincta Panzer, 1799, pt. 63, no. 15; type ?; loc. typ. Austria - Vienna. [de Beaumont, 1951b.]

Giner Marí, 1941a \& Bohart \& Menke, 1976, both give Philanthus as the genus in which Panzer described the species. This must be a lapsus on de Beaumont's part as Cerceris was not described until 1802-03.

Egyptian synonyms: [??]

Collections: the evidence that it occurs in Egypt is unknown

specularis species group

Cerceris specularis A. Costa, 1867 ssp. specularis (s.s.)

Cerceris specularis A.Costa, 1867: 85, $\widehat{\partial}$,, ; lectotype + from Calabria, Italy (MZUN)

Egyptian synonyms:

Cerceris specularis

Honoré, 1942

Range: S Europe, N Africa, SW USSR

chromatica species group

\section{Cerceris chromatica Schletterer, 1887}

Cerceris chromatica Schletterer, 1887: 422, ô; holotype in NHMW; loc. typ. Egypt: El Alag. [Empey, 1973]

Cerceris lateriproducta var flava Mochi, 1938: 184-185, ô, + ; holotype in Cairo (?USNM); loc. typ. Egypt - Thebes. de Beaumont, 1951b, gave Thebes as the locality of the holotype. Mochi did not mention this but gave El Alag as the locality of the $q$ type and Gebel Asfar as that of the ${ }^{\lambda}$ type. De Beaumont synonymised lateriproducta flava with chromatica.

Egyptian synonyms:

Cerceris lateriproducta var. flava

Cerceris chromatica

Cerceris (s.s.) chromatica

Mochi, 1938; Honoré, 1942.

de Beaumont, 1951a \& 1951b; de Beaumont \& Bytinski-Salz, 1959; Pulawski, 1964; Empey, 1973; Bohart \& Menke, 1976.

Giner Marí, 1941b, (fide Schletterer); Honoré, 1942.

Range: Algeria, Egypt, Israel, Aden, Oman

Distribution: Abu Rawash. Bir el Manayit, Dahshur, Giza, Kerdasa, Mersa Matruh, Saqqara

Flight: males (3-7), females (5-7)

Collections: CGR, WJP

\section{Cerceris lateriproducta Mochi, 1939}

Cerceris lateriproducta Mochi, 1939a: 183-185, figs., §̊,, ; syntypes in Cairo (USNM); loc. typ. Egypt - Fayoum, Mansurieh. [de Beaumont, 1951b.]

Egyptian synonyms:

Cerceris lateriproducta

Cerceris (s.s.) lateriproducta

Range: Egypt

Mochi, 1938; Honoré, 1941a \& 1942; de Beaumont, 1951a \& 1951b; Bohart \& Menke, 1976; Guichard, 1993.

Giner Marí, 1941b; Honoré, 1942.

abdominalis species group

\section{Cerceris pharaonum Kohl, 1898}

Cerceris pharaonum Kohl, 1898: 345, pl. 15, figs. 5, 12, $\odot$; holotype $\odot$ in NHMW; loc. typ. Egypt Tourah. [de Beaumont, 1951b.]

Egyptian synonyms:

Cerceris pharaonum

Mochi, 1939a; de Beaumont, 1951b, 1956a \& 1970; de Beaumont \& Bytinski-Salz, 1959; Pulawski, 1964, Bohart \& Menke, 1976.

Cerceris (s.s.) pharaonum Giner Marí, 1941b; Honoré, 1942. 
Range: Chad (Tibesti), Egypt, Israel

Distribution: Abu Rawash, Dahshur, Gebel el Asfar, Giza, Kom Awshim, Saqqara, Turah, 35Km e of Wadi el Natrun

Flight: males (3-5), females (3-6)

Collections: CGR, WJP

chlorotica species group

\section{Cerceris chlorotica Spinola, 1839}

Cerceris chlorotica Spinola, 1839: 496-497, đิ, + ; holotype $\widehat{\sigma}$ in MRSN; loc. typ. Egypt. de Beaumont, 1951b mentions only the $\delta$. He does not indicate that the $q$ is a different species. Cerceris lutea Taschenberg, 1875: 402, $\curvearrowright, q$; holotype + in MLUH; loc. typ. Sudan Khartum. [de Beaumont, 1951b.] De Beaumont, 1951d, recognised the synonymy of lutea with chlorotica.

Cerceris nilotica Schletterer, 1887: 421, đ̋; holotype đo in NHMW; loc. typ. Egypt - Thebes. [de Beaumont, 1951b.] Kohl. 1915, recognised the synonym of nilotica with lutea.

Egyptian synonyms:

Cerceris lutea

Morice, 1897a \& 1911; Storey, 1916; Mochi,

Cerceris (s.s.) lutea

1939a; Honoré, 1941a.

Cerceris chlorotica

Giner Marí, 1941b; Honoré, 1942.

Honoré, 1942; de Beaumont, 1951b; de Beaumont \& Bytinski-Salz, 1959; Pulawski, 1964; Bohart \&

Range: Egypt, Israel Menke, 1976.

Distribution: Dahshur, Giza, 35Km e of Wadi el Natrun

Flight: males (4-6), females (4-6)

Collections: CGR, WJP

\section{Cerceris tyrannica F.Smith, 1856}

Cerceris tyrannica F.Smith, 1856: 447, $q$; lectotype $q$ from Gambia (BMNH) Cerceris sulcipyga Mochi, 1939a: 154-157, figs., đ̊,, ; holotype + in CUE; loc. typ. Egypt Gebel Elba. Synonymised by Empey, 1983: 190.

Egyptian synonyms:

Cerceris sulcipyga

Cerceris (s.s.) sulcipyga

Range: Egypt

capito species group
Mochi, 1939a; de Beaumont, 1951a \& 1951b; Sayed et al, 1964; Bohart \& Menke, 1976.

Giner Marí, 1941b; Honoré, 1942.

\section{Cerceris margarita de Beaumont, 1966}

Cerceris margarita de Beaumont, 1966:203-205, $\partial, q$; holotype $q$ in NRS; loc. typ. Egypt - Gebel Elba.

Egyptian synonyms:

Cerceris margarita de Beaumont, 1966; Bohart \& Menke, 1976.

Range: Egypt

\section{Cerceris spinipectus F. Smith, 1856 ssp. spinolica Schletterer, 1887}

Cerceris spinipectus F. Smith, 1856: 443, ,; type from Trabzon, Turkey (BMNH) Cerceris spinolica Schletterer, 1887: 480, nom. nov. for C. flaviventris Spinola.

Cerceris flaviventris Spinola, 1839: 495-496, ô, (nec Vander Linden, 1829); holotype $\widehat{\sigma}$ in MRSN; loc. typ. Egypt. Made a ssp of spinipectus by de Beaumont, 1951b: 179

Cerceris prisca Schletterer, 1887: 411, ô, O. Morice, 1921: 77, synonymised this species with spinipectus (not spinolica)

Egyptian synonyms:

Cerceris prisca

Cerceris (s.s.) prisca

Morice, 1911.

Giner Marí, 1941b; Honoré, 1942. 
Cerceris capito Lepeletier, 1845

Cerceris (s.s.) capito

Cerceris spinipectus spinolica
Storey, 1916; Mochi, 1939a; Honoré, 1941a; (misidentification).

Giner Marí, 1941b; Honoré, 1942. (misidentification).

de Beaumont, 1951a, 1951b, 1960a \& 1963c; de Beaumont \& Bytinski-Salz, 1959; Pulawski, 1964; Bohart \& Menke, 1976.

Range: Libya (Cyrenaica), Egypt, Israel

Distribution: Abu Rawash, Cairo (environs), Fayyum (28Km w of Shakshuk), Gebel el Asfar, Giza, Hawamdieh, Kom Awshim, Maadi, Wadi Digla

Flight: males (4-5, 8), females (4-6)

Collections: CGR, WJP

Cerceris straminea Dufour, 1853 ssp. komarovii Radoszkowski, 1886

?Cerceris Waltlii Spinola, 1839: 496, đ̊; type lost?; Loc. typ. Egypt. [de Beaumont, 1951b.]

Cerceris straminea Dufour, 1853: 388, + ; holotype + in MNHN; loc. typ. Algeria - Ponteba. [de Beaumont, 1951b.]

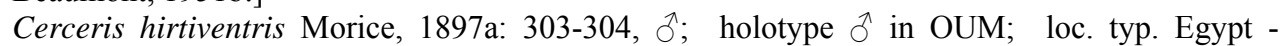
Zeitoun.

Cerceris komarovii Radoszkowski, 1886: 35, §̊,, ; lectotype from Turkmenistan (ZMJU)

Egyptian synonyms:

Cerceris hirtiventris Morice, 1897a.

Cerceris Komarovi Mochi, 1938.

Cerceris Komarowi Honoré, 1941a.

Cerceris (s.s.) Komarowi Honoré, 1942.

Cerceris straminea de Beaumont, 1951a \& 1951b; de Beaumont \&

Cerceris (s.s.) straminea

Bytinski-Salz, 1959; Pulawski, 1964.

Giner Marí, 1941b; Honoré, 1942;

Range: Morocco, Algeria, Libya (Tripolitania), Egypt, Oman, Saudi Arabia

Distribution: Kom Awshim

Flight: males (4-5)

Collections: WJP

rufipes species group

\section{Cerceris rhinoceros Kohl, 1888}

Cerceris rhinoceros Kohl, 1888: 137, ð̊, , ; syntypes from Syria (TMB) [de Beaumont, 1951b.]

Egyptian synonyms:

Cerceris rhinoceros

de Beaumont, 1951b; Bohart \& Menke, 1976.

Range: Turkey, Syria, Egypt

Distribution: Alexandria

\section{Cerceris solitaria Dahlbom 1845}

Cerceris solitaria Dahlbom, 1845: 502, đิ; holotype $\widehat{\jmath}$ in NRS; loc. typ. Egypt. [de Beaumont, 1951b.]

Cerceris erythrocephala Dahlbom, 1845: 500, $q$; holotype $q$ in NRS; loc. typ. Egypt. [de Beaumont, 1951b.] Following various authors suppositions, this synonymy was confirmed by de Beaumont, 1950d.

Cerceris nasuta Lepeletier, 1845: 6, $q$ (nec Latreille, 1809); holotype $q$ in MNHN; loc. typ. Algeria - Oran. [de Beaumont, 1950d \& 1951b.] This synonymy was supposed by Schulthess, 1926 , and confirmed by de Beaumont, 1950d.

Cerceris fasciata Lepeletier, 1845: 30, đ̋ (nec Spinola, 1806); holotype $\widehat{\sigma}$ in MNHN; loc. typ. Algeria - Oran. [de Beaumont, 1951b.] This synonymy was supposed by Schulthess \& Roth, 1926, and confirmed by de Beaumont, 1950d.

Cerceris erythrocephala var. gynochroma Mochi, 1939a: 149, §. De Beaumont, 1951b, commented on the great colour variability in this species and he therefore regarded Mochi's var. gynochroma as invalid.

Egyptian synonyms:

Cerceris tuberculata Villers, var Morice, 1897a. 
Cerceris nasuta

Cerceris fasciata

Cerceris erythrocephala

Cerceris (s.s.) erythrocephala

Cerceris erythrocephala var. gynochroma

Cerceris solitaria

Cerceris (s.s.) gynochroma
Storey, 1916.

Storey, 1916.

Mochi, 1939a; Honoré, 1941a.

Giner Marí, 1941b; Honoré, 1942.

Mochi, 1939a.

de Beaumont, 1950c, 1950 \& 1951b; de Beaumont \& Bytinski-Salz, 1959; Pulawski, 1964.

Giner Marí, 1941b.

doderleini species group

\section{Cerceris sinaitica de Beaumont, 1951}

Cerceris sinaitica de Beaumont, 1951a: 179, क; type in Cairo (?USNM); loc. typ. Egypt - Sinai, Wadi um Mitla. [de Beaumont, 1951b.]

As Mochi, 1939a, described this species as "Cerceris döderleini Schulz, 1905", it was a case of his misidentifying the species. Therefore de Beaumont's sinaitica was not a "nom. nov." as he claimed, but a new species. This is borne out by the fact that he seems to have used Mochi's specimens as the type series.

Egyptian synonyms:

Cerceris Döderleini

Cerceris (s.s.) doderleini

Cerceris (s.s.) Döderleini

Cerceris sinaitica

Range: Sinai, Israel

Distribution: Sinai - Wadi Um Mitla

\section{histerisnica species group}

\section{Cerceris histerisnica (Spinola, 1839)}

Nectanebus histerisnicus Spinola, 1839: 491-492, + ; syntype 9 from 'Egypt' (MRSN)

Nectanebus Fischeri Spinola, 1839: 490, ô., nec Cerceris fischeri Spinola, 1838

Egyptian synonyms:

Nectanebus fischeri

Cerceris histerisnica

Range: Egypt, Israel

Mochi, 1939b; Honoré, 1942; de Beaumont, 1949a; de Beaumont \& Bytinski-Salz, 1959.

Bohart \& Menke, 1976 as a new combination, arising from their synonymising the genus Nectanebus. This made $N$. fischeri a junior homonym of Cerceris fischeri Spinola, 1838.

Distribution: Abu Rawash, Ben Yussef, Dahshur, Gebel el Asfar, Sinai - Wadi Mitla

Flight: males (3-4), females (3-4)

Collections: AM, CGR

\section{Doubtful Records}

Over the years the Egyptian synonyms have accumulated a considerable number of species which cannot justify their claim to be regular members of the fauna. These have arisen for a variety of reasons. The largest number are on the Egyptian list because of misidentification. In many cases as will have been noted earlier in this paper, the true identification of these species has been resolved, but in others this has not been possible. In some cases the specimens were described as new species, but the original descriptions were so poor and the type material is no longer available so that it is not known to what species, in some cases to which genus even, these descriptions were to apply. These are "nomina dubia". This applies to a number of species described by Walker. Innes in his 1911 paper describes a box of pins 
and labels from which all trace of the insects themselves had vanished, consumed by pests, which appeared to have been the remains of a part of the collection made by Lord and identified by Walker. In the absence of the specimens all that this has achieved is to perpetuate these unidentifiable names. There are a few cases where species whose normal range is far from Egypt have been recorded at Port Said or Suez. These are clearly accidental occurrences where the insects had been transported on ships to these ports - stowaways. Finally, there are two cases of names being reported, which names have never been formally described. These are "nomina nuda".

For completeness of the record and so that any consultation to the papers in which they were reported may be made with knowledge of the circumstances surrounding them, these names are listed below with the references to them and a note on their status.

\section{Chlorion lobatum (Fabricius, 1775)}

Sphex (Chlorion) lobatus - Honoré, 1944a.

This species, one from the Oriental Region, has only been recorded from Port Said, where it presumably arrived by ship. It must be regarded as an accidental visitor rather than an Egyptian species.

\section{Chlorion tricolor Walker, 1871}

Chlorion tricolor - Innes, 1911.

Innes cites this name from a Walker label on a specimen from Wady Gharandel. I assume it is an error of Innes / Walker, a lapsus for bicolor Walker (which is a synonym of C.semenowi occidentale).

\section{Sphex cahirensis André, 1888}

Sphex cahirensis - Honoré, 1942.

This name has never been published and is a nomen nudum. It is not included in Bohart \& Menke's list of nomina nuda in the genus Sphex.

\section{Sphex luteipennis Mocsáry, 1883}

Sphex luteipennis - Kohl, 1890.

Kohl gives the distribution as Egypt, Zanzibar, Ceylon, Amboina. Bohart \& Menke, 1976, treating this species as a subspecies of S. praedator F. Smith, say it occurs in Indonesia: s. Moluccas, Ambon \& Buru. It does not seem a convincing Egyptian record.

\section{Parasphex fervens Fabricius}

Parasphex fervens - Innes, 1911.

Innes cites this from a Walker label of a specimen from Tor. It is presumably a Prionyx species, but the specific name, of which Linneaus and not Fabricius was the author, is one referring to a widespread species in the U.S., central and south America.

\section{Ammophila filata Walker, 1871}

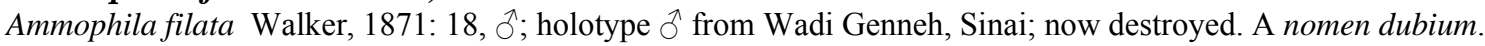

\section{Ammophila heydenii Dahldom, 1845}

Ammophila Heydenii - Kohl, 1906.

This is the only reference found of this species occurring in Egypt. Is it an error on Kohl's part? In de Beaumont and Bytinski-Salz, 1955, it is specifically stated that this species does not occur in Egypt.

\section{Ammophila strenua Walker, 1871}

Ammophila strenua - Kohl, 1906; Innes, 1911.

Innes cites this Walker label on a specimen from Wady Genneh. Kohl thought it might be a junior synonym of Podalonia dispar (Taschenberg), and listed it under that species with a query mark. In any case the name is a junior homonym of strenua Cresson, 1865 and therefore cannot be used. 
Diodontus minutus (Fabricius, 1793)

Diodontus minutus - Honoré, 1942.

This record must be regarded with suspicion. De Beaumont, 1960a: 248, stated that he did not know of minutus in north Africa.

\section{Larrada diversa Walker, 1871}

Larrada diversa - Innes, 1911.

Innes cites a Walker label from on a specimen from Cairo. Bohart \& Menke, 1976, think it may perhaps be a Larra species. It remains a nomen dubium.

\section{Tachytes decoratus Walker, 1871}

Tachytes decoratus - Innes, 1911; Pulawski, 1962; Bohart \& Menke, 1976.

Innes cites a Walker label from on a specimen from Wadi Feiran. Pulawski said the type was lost and that the species could not be recognised from the very brief description given by Walker. It remains a nomen dubium.

\section{Tachytes lugubris Walker, 1871}

Tachytes lugubris - Innes, 1911; Pulawski, 1962; Bohart \& Menke, 1976.

Innes cites a Walker label from on a specimen from Wadi Feiran. Pulawski said the type was lost and that the species could not be recognised from the very brief description given by Walker. It remains a nomen dubium.

\section{Tachytes plagiatus Walker, 1871}

Tachytes plagiatus - Innes, 1911; Pulawski, 1962; Bohart \& Menke, 1976.

Innes cites a Walker label from on a specimen from Horr Tamanib; this locality cannot be traced - it may not have been in Egypt [World Catalog says 'Sudan']. Pulawski said the type was lost and that the species could not be recognised from the very brief description given by Walker. It remains a nomen dubium.

\section{Tachysphex sordidus (Dahlbom, 1845)}

Tachysphex sordidus - de Beaumont, 1940b \& 1947; Honoré, 1942; Pulawski, 1971.

Although the type of this species was said to originate from Egypt, de Beaumont believed it to have been wrongly labelled and that it came in fact from Rhodes. The species was known to de Beaumont only from Rhodes and Cyprus. Pulawski, 1971, did not list Egypt in its distribution and confirmed Rhodes as its type locality. Pulawski, 1973, specifically stated its distribution as "Eastern Mediterranean (not Egypt)". See also Cerceris dispar below , another Dahlbom species with Egypt / Rhodes doubts.

Lindenius pygmaeus (Rossi, 1794) ssp. algirus Kohl, 1892

Crabro (Lindenius) armatus Vander Linden, 1829: 69, §̂, ᄋ [Honoré, 1942]

Crabro algirus Kohl, 1892: 202,, ; holotype $\odot$ from El-Kantour Mt, Algeria (NHMW)

Lindenius armatus var. algirus Maidl, 1924: 234 from Shellal near Aswan, Egypt (Honoré, 1942.)

De Beaumont, 1956b, stated that he had not seen this species from Egypt despite it being cited by Honoré in two different subspecies.

\section{Lindenius mesopleuralis (F.Morawitz, 1890)}

Crabro (Lindenius) mesopleuralis - Kohl, 1915.

De Beaumont, 1956b, in his paper on the palaearctic species of Lindenius does not record this species from Egypt.

\section{Rhopalum fraternum F.Smith: Walker 1871: 27}

Rhopalum fraternum - Honoré, 1942.

Nomen nudum. Honoré says of this, “indiqué des environs du Caire, par Walker, n’a pas été décrit." Types collected from unknown locality, now destroyed.

\section{Crossocerus perpusillus (Walker, 1871)}

Crabro (Crossocerus?) perpusillus - Kohl, 1915. Crabro (Lindenius) perpusillus - Honoré, 1942.

Crossocerus perpusillus - Bohart \& Menke, 1976.

De Beaumont, 1956b, says the species described as a Lindenius which is not recognizable but is, perhaps, a Crossocerus. 
Tracheliodes quinquenotatus (Jurine, 1807)

Crabro quinquenotatus - Kohl, 1915.

Crabro (Brachymerus) quinquenotatus - Honoré, 1942.

The only Egyptian record seems to have been from Port Said which suggests it may have been an accidental visitor only.

Didineis lunicornis (Fabricius, 1798)

Alysson (Didineis) lunicornis - Honoré, 1942, fide Handlirsch.

Egypt is not mentioned under Didineis lunicornis in Handlirsch, 1887: 44, so presumably this was an error by Honoré.

\section{Stizus biclipeatus (Christ)}

Larra nubilipennis Smith - Innes, 1911

Innes cites a Walker label of a specimen from Wadi Hebran; the name is regarded as a junior synonym of Stizus biclipeatus, a species known from India. The record thus seems to be doubtful.

\section{Bembecinus bernardi de Beaumont, 1954}

Bembecinus bernardi de Beaumont - Bohart \& Menke, 1976

Incorrectly listed as Egyptian by Bohart \& Menke (1976) (Pulawski, World Catalogue)

\section{Bembecinus tridens (Fabricius)}

Larra tridens Walker - Innes, 1911

Innes cites a Walker label of a specimen from Tadjourah (Djibouti) which cannot be correct on geographical grounds. Does it refer to Fabricius's species which has not otherwise been recorded from Egypt?

\section{Bembix tranquebarica (Gmelin)}

Bembix trepanda Dahlbom - Innes, 1911

Innes cites a Walker label of a specimen from Wadi Feiran. This name is a junior synonym of B. tranquebarica, a species known from India. It seems to be an unlikely record.

\section{Bembix brunneri Handlirsch, 1893}

Bembex brunneri Handlirsch, 1893: 848, §̊,, ; loc.typ. Algeria (NHMW)

Morice (1911) cites some non-Egyptian specimens "determined with the help of Egyptian specimens named for me by Handlirsch".

\section{Philanthus sulphureus F. Smith, 1856}

Philanthus sulphureus - Innes, 1911.

Innes records Walker's label as sulfureus from Wadi Feiran. This species occurs in north India, (Bohart \& Menke, 1976) and this must be regarded as a doubtful record.

\section{Cerceris dispar Dahlbom, 1845}

Cerceris dispar - de Beaumont, 1950d \& 1958b.

Although the type locality was given as Egypt, de Beaumont, in both papers, thinks this was an error and it was really Rhodes and that the species does not occur in Egypt. This seems similar to Tachysphex sordidus Dahlbom mentioned above.

\section{Cerceris schmiedeknechti Kohl, 1898}

Cerceris Schmiedeknechti - Honoré, 1941a.

Cerceris (s.s.) schmiedeknechti - Giner Marí, 1941 b.

Cerceris (s.s.) Schmiedeknechti - Honoré, 1942.

Cerceris schmiedeknechti - de Beaumont, 1951b.

This species was described from specimens taken by Schmiedeknecht in Oran and Egypt. It has never been found again in Egypt. Honoré, 1941a, said he had not seen it and de Beaumont, 1951b, wondered whether the record from Egypt was an error. 


\section{Cerceris leucochroa Schletterer, 1887}

Cerceris (s.s.) leucochroa - Giner Marí, 1941b; Honoré, 1942.

Both the above authors give Schletterer as their source for the occurrence of this species in Egypt. Giner Marí cites Schletterer as giving the distribution as "Egypt - Kordofan". As Kordofan is in the Sudan, this raises the query of whether this species does occur in Egypt.

\section{References}

Alfieri A (1946) Les espèces égyptiennes du genre Ammophila Kirby (Hymenoptera-Aculeata: Sphecoidea-Sphecidae). Bull. Soc. ent. Egypte, 30: 105-142.

Alfieri A (1961) Deux nouveaux ammophiles de la faune egyptienne. Bull. Soc. ent. Egypte, 45: 139-141.

Andrade NF de (1954) Palaearctic Miscophus of the gallicus group. Memorias e estudos do Museu ZoolOgico da Universidade de Coimbra, 226, 87 pp.

Andrade NF de (1956) Western palaearctic Miscophus of the handlirschii group (Hymenoptera: Sphecidae). MemOrias e estudos do Museu Zoologico da Universidade de Coimbra, 239, 40 pp.

Andrade NF de (1960) Palaearctic Miscophus: bicolor group and isolated species (Hymenoptera: Sphecidae). MemOrias e estudos do Museu Zoologico da Universidade de Coimbra, 262, 136 pp.

André E (1888) Species des Hyménoptères d'Europe et d'Algérie. Beaune.

Antropov A (1995) Four new species of the digger wasp genus Trypoxylon Latreille (Hymenoptera, Sphecidae) of the Palaearctic and Oriental regions, with taxohnomic notes on those already described. Russian Entomological Journal 3: 123-133

Arnold G (1923) The Sphegidae of South Africa, part III. Annals of the Transvaal Museum, 9 (4): 191-253.

Arnold G (1924) The Sphegidae of South Africa, part V. Annals of the Transvaal Museum, 11(1): 1-73.

Arnold G (1925) The Sphegidae of South Africa, part VI. Annals of the Transvaal Museum, 11 (3): 137-175.

Arnold G (1927) The Sphegidae of South Africa, part VIII. Annals of the Transvaal Museum, 12 (2): 55-131.

Arnold G (1928a) The Sphegidae of South Africa, part X. Annals of the Transvaal Museum, 12 (3):233-279, pls. 8-11.

Arnold G (1928b) The Sphegidae of South Africa, part XI. Annals of the Transvaal Museum, 12 (4):338-375.

Arnold G (1929) The Sphegidae of South Africa, part XII. Annals of the Transvaal Museum, 13 (4):217-319.

Arnold G (1940) New Species of African Hymenoptera, No. 4. Annals of the Transvaal Museum, 20 (2): 101-143, pl. 5.

Arnold G (1951) Sphecidae and Pompilidae (Hymenoptera) collected by Mr K.M.Guichard in West Africa and Ethiopia. Bull. Brit. Mus. (Nat.Hist.) Ent., 2 (13): 97-183 \& pls. 4 \& 5.

Balthasar V (1954) Ein Beitrag zur Kenntnis der palaestinischen Sphecidae. Opuscula hymenopterologica, XIV, Acta Ent. Mus. Nat. Pragae, 28 (1952): 267-284 [Miscophus honorei n.n. for M. rubriventris Honoré]

Beaumont J de (1936) Les Tachysphex de la Faune Française (Hym. Sphecidae). Ann. Soc. Ent. France, 105: 177-212.

Beaumont J de (1940a) Etude préliminaire des Leptolarra Cam. (= Notogonia Costa) de la faune égyptienne (Hymenoptera: Sphecidae). Bulletin ent Soc. Fouad 1er : 17-18.

Beaumont J de (1940b) Les Tachysphex de la faune égyptienne (Hymenoptera: Sphecidae). Bulletin ent Soc. Fouad 1er, : 153-179.

Beaumont J de (1947) Nouvelle étude des Tachysphex de la faune égyptienne (Hymenoptera: Sphecidae). Bull. Soc. Fouad 1er Entom., 31: 141-216.

Beaumont J de (1949a) Les Philanthus et Philponidea de l'Afrique du N.-O. (Hym. Sphecid.). Mitteilungen der Schweizerischen Entomologischen Gesellschaft, 22 (2): 173-216.

Beaumont J de (1949b) Contribution à l'étude du genre Palarus Latr. (Hym. Sphecid.). Revue Suisse de Zoologie, 56 (35): 627-673.

Beaumont J de (1950a) Sphecidae (Hymenoptera) récoltés en Algérie et au Maroc par M. Kenneth M. Guichard. Bulletin of the British Museum (Natural History), Entomology, 1 (6): 391-427.

Beaumont J de (1950b) Notes sur quelques Sphecidae nord-africains décrits par G. Gribodo. Annali del Museo Civico di Storia Naturale di Genova, 64: 261-267.

Beaumont J de (1950c) Résultats de l'expédition de l'Armstong Collège à l'Oasis de Siwa (désert libyque) 1935, sous la direction du Professeur J. Omer-Cooper. Bull. Soc. Fouad 1er Entom., 34 (1): 1-21.

Beaumont J de (1950d) Synonymies de quelques Cerceris. 1. (Hym. Sphecid.). Mitteilungen der Schweizerischen Entomologischen Gesellschaft, 23 (3): 317-328.

Beaumont J de (1951a) Synonymies de quelques Cerceris. 2. (Hym. Sphecid.). Mitteilungen der Schweizerischen Entomologischen Gesellschaft, 24 (2): 175-180.

Beaumont J de (1951b) Contribution à l'étude des Cerceris nord-africains. Eos, 27: 299-408.

Beaumont J de (1952a) Voyages de M. A.Giordani Soika au Sahara. Ve note, Sphecidae (Hym.) du Hoggar. Boll. Soc. Veneziana Stor. Nat. Mus. Civ. St. Nat., 6 (2): 187-199.

Beaumont J de (1952b) Les Hoplisoides et les Psammaecius de la région paléarctique (Hym. Sphecid.). Mitteilungen der Schweizerischen Entomologischen Gesellschaft, 25 (3): 211-238.

Beaumont J de (1952c) Sphecidae paléarctiques décrits par M. Spinola. Bollettino del Museo di Zoologia dell'Universita di Torino 3: 39-51

Beaumont $\mathrm{J}$ de (1953a) Contribution à l'étude du peuplement de la Mauritanie (Hymenoptera: Sphecidae). Bulletin de l'Institut Français d'Afrique Noire, 15: 171-177 
Beaumont J de (1953b) Notes sur quelques Sphecidae de la collection A.Costa (Hym.). Annuario dell'Istituto e Museo di Zoologia della Universita di Napoli 5(10): 1-15

Beaumont J de (1954b) Les Bembecinus de la région paléarctique (Hym. Sphecid.). Mitteilungen der Schweizerischen Entomologischen Gesellschaft, 27 (3): 241-276.

Beaumont J de (1954c) Contributions entomologiques de l'expedition finlandaise aux Canaries, 1947-51. No. 8. Sphecidae. Societas Scientiarum Fennica, Commentationes Biologicae, 14 (8): 1-6.

Beaumont J de (1954e) Notes sur le genre Prosopigastra (Hym. Sphecid.). Mitteilungen der Schweizerischen Entomologischen Gesellschaft, 27 (2): 153-156.

Beaumont J de (1955) Hyménoptères récoltés par une mission suisse au Maroc (1947). Sphecidae 3. Bull. Soc. Sci. Nat. Maroc, 34 (1954): 169-197. [OD of Parapiagetia zorah, Prosopigastra zalinda, ssp. africana]

Beaumont J de (1956a) Sphecidae (Hym.) récoltés en Libye et au Tibesti par M. Kenneth M. Guichard. Bulletin of the British Museum (Natural History), Entomology, 4 (5): 167-215.

Beaumont J de (1956b) Notes sur les Lindenius paléarctiques. (Hym.Sphecid.). Mitteilungen der Schweizerischen Entomologischen Gesellschaft, 29 (2): 145-185.

Beaumont J de (1957) Bembix turca Dahlb. et flavescens Sm. (Hym. Sphecid.). Revue Suisse de Zoologie, 64 (33): 607-623.

Beaumont J de (1958b) Cerceris de Grèce et de Chypre. Mitteilungen der Schweizerischen Entomologischen Gesellschaft, 31 (3 \& 4): 270-290.

Beaumont J de (1958d) Hyménoptères Sphécides de la mission du Tassili des Ajjer (1949). Travaux de l'Institut de Recherches Sahariennes, (Série de Tassili Tome III): 55-71.

Beaumont J de (1959) Le genre Laphyragogus Kohl (Hym. Sphecid.). Revue suisse de Zoologie, 66 (31): 723-734.

Beaumont J de (1960a) Sphecidae (Hym.) récoltés en Tripolitaine et en Cyrénaïque par M. Kenneth M. Guichard. Bulletin of the British Museum (Natural History), Entomology, 9 (3):219-251.

Beaumont J de (1961a) Notes sur les Philanthus paléarctiques (Hym. Sphecid.). Mitteilungen der Schweizerischen Entomologischen Gesellschaft, 33 (1960) (4); 201-212.

Beaumont J de (1961b) Sphecidae de l'île de Crète (Hym.). Mitteilungen der Schweizerischen Entomologischen Gesellschaft, 34 (1):43-52.

Beaumont J de (1961c) Les espèces méditerranéennes du genre Pison Jur. (Hym.Sphecid.). Mitteilungen der Schweizerischen Entomologischen Gesellschaft, 34 (1): 53-56.

Beaumont J de (1961d) Les Liris F. du bassin méditerranéen. Mitteilungen der Schweizerischen Entomologischen Gesellschaft, 34, (3):213-252.

Beaumont J de (1962) Notes sur les Sphex paléarctiques du sous-genre Chlorion Latr. (Hymenoptera Sphecidae). Bol. Ist. Ent. Univ. Bologna, 26: 29-41.

Beaumont J de (1963a) Les Ammophiles paléarctiques du groupe de nasuta (Hym. Sphecid.). Revue suisse de Zoologie, 70 (1): $1-24$.

Beaumont J de (1963c) Une intéressante race locale de Cerceris spinipectus Sm. (Hym. Sphecid.). Mitteilungen der Schweizerischen Entomologischen Gesellschaft, 35 (3 \& 4): 296-300.

Beaumont J de (1964c) Le genre Solierella Spinola en Europe et dans la Méditerranée orientale (Hym. Sphecid.). Mitteilungen der Schweizerischen Entomologischen Gesellschaft, 37 (1-2) 49-68.

Beaumont J de (1965) Les Sphecidae de la Grèce (Hym.). Mitteilungen der Schweizerischen Entomologischen Gesellschaft, 38: 1-65 [OD of Tachysphex grandii]

Beaumont J de (1966) Quelques Sphecidae de la faune d'Egypte (Hym.). Mitteilungen der Schweizerischen Entomologischen Gesellschaft, 38 (3-4): 203-212.

Beaumont J de (1967b) Hymenoptera from Turkey. Sphecidae, I. Bulletin of the British Museum (Natural History), Entomology, 19, (5):253-382.

Beaumont J de (1968a) Sphecidae des Iles Canaries. (Hymenoptera). Bulletin of the British Museum (Natural History), Entomology, 21 (5): 245-278.

Beaumont J de (1968b) Sphecidae paléarctique nouveaux ou peu connus (Hym.). Mitteilungen der Schweizerischen Entomologischen Gesellschaft, 41 (1-4): 143-168.

Beaumont J de (1970) Sphecidae de l'Iran (Hym.) (Résultats des voyages entomologiques de Willi Richter, Stuttgart, en Iran en 1954 et 1956). Stuttgart Beitr. Nat., no.220: 1-18

Beaumont J de \& H Bytinski-Salz (1955) The Sphecidae (Hymen.) of Erez Israel. I. (Subfam.: Sphecinae, Nyssoninae: Trib.: Bembicini, Stizini). Bulletin of the Research Council of Israel, 5 (1): 32-60.

Beaumont J de \& H Bytinski-Salz (1959) The Sphecidae (Hymen.) of Eretz Israel. II. Subfam.: Nyssoninae (Tribes: Gorytini, Nyssonini, Alyssonini) and Philanthinae. Bulletin of the Research Council of Israel, B9, 103-151.

Beaumont J de, H Bytinski-Salz \& W. Pulawski (1973) The Sphecidae (Hymen.) of Erez Israel. III. Subfamilies: Astatinae, Larrinae, Trypoxyloninae, Pemphredoninae, Crabroninae, Oxybelinae. Israel Journal of Entomology, 8: 1-26.

Berland L (1950) Contribution à l'étude de l'Air. Hyménoptères Sphecoidea, Vespoidea, Ichneumonoidea. Mémoires de l'Institut Francaise d'Afrique Noire, 10: 294-301

Bohart RM \& AS Menke (1976) Sphecid wasps of the world. A generic revision. University of California Press, ix $+695 \mathrm{pp}$.

Brullé A (1833) Expédition Scientifique de Morée, Section des sciences physiques, tome III - 1re partie. Zoologie. Deuxième section - des Animales articulés, Paris: 1-400.

Cameron P (1889) Hymenoptera Orientalis [sic]; or controbutions to a knowledge of the Hymenoptera of the Oriental Zoological Region. Memoirs \& Proceedings of the Manchester Literary \& Philosophical Society (Series 4) 2: 91-152.

Carruccio A (1872) Diagnosi di una nuova specie di Pelopoeus. Bollettino della Societa Entomologica Italiana 4: 273-5

Chevrier F (1867) Hyménoptères nouveaux ou rares du Bassin du Léman. Mittheilungen der Schweizerischen Entomologischen Gesellschaft 2: 229-235. 
Christ JL (1791) Naturgeschichte, Klassification und Nomenklatur der Insekten vom Bienen, Wespen und Ameisengeschlecht; asl der fünften Klasse fünfte Ordnung der Linneischen Natursystems von den Insekten: Hymenoptera. Mit häutigen Flügeln. Hermannische Buchhandlung, Frankfurt am Mein. 535 pp.

Costa A (1858) Ricerche Entomologiche sopra i Monte Partenii Nel Principato Ulteriore. Napoli. 29 pp.

Costa A (1867) Prospetto sistematico degli Imenotteri italiani da servire di prodromo imenotterologica Italiana. Annu. Mus. Zool. Univ. Napoli, 4 (1864): 59-100

Costa A (1869) Prospetto sistematico degli Imenotteri Italiani da servire di Prodromo della Imenotterologia Italiana (continuazione) Annuario del Museo Zoologico della R. Universita di Napoli, 5 (1865): 60-116

Costa A (1875) [OD of (Liris) argyropyga]

Costa A (1882) Notizie ed osservazioni sulla geo-fauna sarda, Memoria Prima, Risultamente di riserche fatte in Sardegna nel Settembre 1881. Atti Roy. Acad. Sci. Fis. Mat Napoli, IX: 1-42

Costa A (1886) Fauna del Regno di Napoli ossia enumerazione, di tutti gli Animali ... continente la descrizione de' nuovi o poco esattemente conosciuti ... di O.G.Costa (continuata da A.Costa), 1859-1886, Imen. Pompilidae, 69 pp

Costa A (1893a) Miscellanea entomologica, memoria quarta. Atti accad. sc. fis. Mat. Napoli (2), IV, no.14: 1-30 + pl. IV.

Costa A (1893b) Miscellanea entomologica, memoria quarta. Rendiconti della Reale Accademia della Scienze Fisiche e Matematiche di Napoli (2), VII: 99-102

Dahlbom AG (1832) Exercitationes Hymenopterologicae Ad illustrandum Faunam Svecicam, quas Venia Ampliss. Facultatis Philos. Acad. Lund. Proponunt Gustav. Dahlbom, Historiae Natur. Doc., Societ. Linn. Holm. Membr., et N.P.Ringstrand, Ostro-gothi. In Acad. Carolina die XXVII Octobris MDCCCXXII. part. IV, Londini Gothorum: 49-64

Dahlbom AG (1845) Hymenoptera Europaea praecipue nexum systamticus associatis. Tomus: Sphex in sensu Linnaeus. Officina Lundbergiana, Lund. 528 pp.

Dalla Torre CG de (1897) Catalogus Hymenopterorum hucusque descriptorum systematicus et synonymicus 8, Fossores (Sphegidae). Lipsiae: 1-749.

De Stefani T (1881) Osservazioni entomologiche fatte nel territorio di Sciacca e descrizione d'un nuovo Tachytes. Il Naturalista Siciliano, 1: 38-42.

De Stefani T (1894) Miscellanea entomologica. Il Naturalista Siciliano, 3: 9-13

Dufour L (1841) Observations sur les métamorphoses du Cerceris bupresticida et sur l'industrie et l'instinct entomologique de cet Hyménoptère. Annales des Sciences Naturelles. Zoologie (Série 2) 15: 353-370

Dufour L (1853) Signalements de quelques espèces nouvelles et peu connues d'Hyménoptères algériens. Ann. Soc. Ent. France, (3) 1: 375-382. (1863 (per Kohl, 1890)

Empey HN (1973) Descriptions and records of new and little known species of Cerceris Latreille, 1802 from Socotra and southern Arabia (Hymenoptera: Sphecidae). J. ent. Soc. sth. Afr., 35 (1): 1-23.

Empey HN (1983) The types of Cerceris Latr. from the Ethiopian and Madagascan regions (Hymenoptera: Sphecidae: Philanthinae). Journal of the entomological Society of Southern Africa 46: 161-203

Eversmann E (1849) Fauna Hymenopterologica Volgo-Uralensis. Fam. III. Sphegidae Latr. Bull. Soc. Imp. Natural. Moscou, 22 (3): 359-436.

Fabricius J (1775) Systema Entomologiae. Flensburg \& Leipzig. 832 pp.

Fabricius J (1781) Species Insectorum exhibentes eorum differentias specificas....,1. Hamburg \& Kiel. 517 pp.

Fabricius J (1787) Mantissa Insectorum. Copenhagen. 348 pp.

Fabricius J (1793) Entomologia systematica emendata et aucta. Copenhagen, 519 pp.

Fabricius J (1798) Supplementum Entomologiae Systematicae. Copenhagen, 572 pp.

Fabricius J (1804) Systema Piezatorum secundum. Braunschweig. 470 pp.

Forster J (1771) Novae species Insectorum. London, $100 \mathrm{pp}$.

Gadallah NS (1996) Review of the genus Philanthus F. in Egypt with notes on little known species (Hymenoptera: Sphecidae). Bulletin of the Entomological Society of Egypt 74:68-80

Gadallah NS (1997) Revision of the Egyptian species of the genus Bembix (Hymenoptera Sphecidae). Bollettino della Società Entomologica Italiana 129:257-270

Gadallah NS (2001) A comparative morphological study of the skeletal parts of the sting apparatus in some Stizus species from Egypt (Sphecidae: Bembicinae). Egyptian Journal of Zoology 37:255-265

Gadallah NS (2002) Male genitalia as a diagnostic character in determining Bembex F. species from Egypt (Hymenoptera: Sphecidae). Zoology in the Middle East 25:599-66

Gayubo SF (1991) The genus Philanthus Fabricius, 1790 in the Iberian peninsula (Hym., Sphecidae). Entomologist's Monthly Magazine,127: 127-137.

Germar EF (1817) Reise nach Dalmatien und in das Gebiet von Ragusa. Brockhaus, Leipzig. 323 pp.

Giner Marí J (1941a) Cerceris Paleárticos. I. Monografía de los Cerceris de España (Hym. Spheg.), Eos, 15 (1939): 3-93, pls. 1-2.

Giner Marí J (1941b) Cerceris Paleárticos. II. Los Cerceris del Africa paleártica (Hym. Spheg.). Eos, (1-2): 135-291.

Giner Marí J (1945) Resultados cientificos de un viaje entomologico al Sahara español y zona oriental del Marruecos español. Familias Sphecidae y Mutillidae (sensu lato). (Hym. Sphec. y Mut.). Eos, 20: 351-385.

Giner Marí J (1947) Himenopteros del Sahara Español. III. Familias: Sphecidae, Apterogynidae, Mutillidae y Psammocharidae. Eos, 23: 17-31.

Girard MJA (1881) Note sur le synonyme de Philanthus triangulum et P. Abd-el Kader. Ann. Soc. ent. Fr. 6(1), Bull.: cxxviii. Gribodo G (1879) Note Imenotterologiche. Annali del Museo Civico di Storia Naturale di Genova 14: 325-347

Gribodo G (1924) Imenotteri Aculeata di Cirenaica Raccolti dal Prof. Alessandro Ghigi durante l'escursione organizzata dal Touring Club Italiano 15-24 Aprile 1920. Atti Soc. Ital. Sc. Nat. Mus. Civ. St. Nat. Milano, 63: 245-268.

Guérin-Méneville H (1844) Iconographie du règne animal de G.Cuvier. Fain \& Thunot, Paris. Vols 46-50, 576 pp 
Guichard KM (1980) A Preliminary Account of the Sphecid Wasps of Oman (Hymenoptera, Sphecidae). Journal of Oman Studies, Special Report no. 2, The Scientific Results of the The Oman Flora and Fauna Survey, 1977, (Dhofar): 223-232.

Guichard KM (1988a) Hymenoptera: Sphecidae: Subfam. Sphecinae of the Araban Pemimsula. Fauna of Saudi Arabia, 9: 115131.

Guichard KM (1988b) The Genus Palarus (Hymenoptera: Sphecidae) in Arabia. Fauna of Saudi Arabia, 9: 132-137.

Guichard KM (1989a) The Genus Bembix (Hymenoptera: Sphecidae) in Arabia. Fauna of Saudi Arabia, 10: 134-151.

Guichard KM (1989b) The Genera Stizus and Stizoides (Hymenoptera: Sphecidae) in Arabia. Fauna of Saudi Arabia, 10: 152159.

Guichard KM (1990) The Genus Oxybelus (Hymenoptera: Sphecidae) in Arabia. Fauna of Saudi Arabia, 11: 277-285.

Guichard KM (1991) Old World species of Belomicrus A. Costa, 1871 (Hymenoptera, Sphecidae). Entomofauna, Zeitschrift für Entomologie, 12 (22) 353-372.

Guichard KM (1993) The Genus Cerceris (Hymenoptera: Sphecidae) in Arabia. Fauna of Saudi Arabia, 13: 152-169.

Guiglia D (1932) Spedizione scientifica all'oasi di Cufra (marzo-luglio 1931). Imenotteri Aculeati. Ann. Mus. Civ. St. nat. G. Doria, 55: 466-486.

Guiglia D (1939) Imenotteri aculeati del Fezzan sud occidentale e dei Tassili d'Agger (Missione Scortecci 1936). Atti della Società Italiana di Scienze Naturali, 78: 179-193.

Gussakovskij VV (1931) [Contributions à la connaissance des espèces paléarctiques orientales du genre Gastrosericus Spin. (Hymenoptera, Sphecidae)] (in Russian) Yezhegodnik Zoologicheskogo Muzeya Akademii Mauk SSSR 31: 449-457

Gussakovskij VV (1933) Sphegidae et Psammocharidae a Cl. N. Zarudnyi in Persia orientali collectae. Trudy Zoologicheskogo Instituta Akademii Nauk SSSR 1: (1932): 269-307 (actually 369-407)

Gussakovskij VV (1952) [New and little-known species of Psammocharidae and Sphecidae of western Tadjikistan]. Trudy Zoologicheskogo Instituta Akademii Nauk SSSR 10: 199-288.

Handlirsch A (1887-1895) Monographie der mit Nysson und Bembex verwandten Grabwespen, (parts 1-7 \& "Nachträge und Schlusswort"), Sitzungsberichten der Kaiserl. Akademie der Wissenschaften in Wien, Mathem.-naturw. Classe, 95: 246$421+5$ pls. $(=1887) ; 96: 219-311+2$ pls., $(=1888 \mathrm{a}) ; 97: 316-565+3$ pls., $(=1888 \mathrm{~b}) ; 98: 440-517+2$ pls., $(=1889)$; 99: 77-166 + 1 pl., (= 1890); 101: 25-205 + 3 pls., (= 1892); 102: 657-942 + 7 pls., $(=1893) ; 104: 801-1079+2$ pls., $(=$ 1895).

Handlirsch A (1898) Ueber die von Dr O Schmiedeknecht in Nordafrika gesammelten Nyssonidae. Verhandlungen der kaiserlich-königlichen Zoologisch-Botanischen Gesellschaft in Wien 48: 485-490

Hensen RV (1988) Revision of the nominate subgenus (Chalybion) Dahlbom, (Hymenoptera, Sphecidae). Tijdschrift voor Entomologie, 131: 13-64.

Honoré A-M (1941a) Notes sur quelques Cerceris de la faune égyptienne. Bulletin de la Société Fouad 1er d'Entomologie, 25: $145-162$

Honoré A-M (1941b) Contribution à la connaissance des espèces égyptiennes du genre Palarus Latr. Bulletin de la Société Fouad 1er d'Entomologie, 25: 191-202.

Honoré A-M (1942) Introduction à l'étude des Sphégides en Egypte. Bulletin de la Société Fouad 1er d'Entomologie, 26: 2580.

Honoré A-M (1944a) Revue des espèces égyptiennes du genre Sphex Linné, 1758 (Hymenoptera : Sphegidae). Bulletin de la Société Fouad 1er Entomologique, 28: 45-79.

Honoré A-M (1944b) Matériaux pour une Monograghie (sic) des Miscophus d'Egypte (Hymenoptera Aculeata : Sphegidae). Bulletin de la Société Fouad 1er Entomologique, 28: 119-143.

Innes W [Innes Bey] (1912) Une liste d'Insectes recueillis probablement par J. Lord en Egypte et déterminés par F. Walker. Bulletin de la Société Entomologique d'Egypte, 1911: 97-115.

Jurine L (1807) Nouvelle méthode de classer les Hyménoptères et les Diptères. Hyménoptères. Vol. 1. JJ Paschoud, Genève. $319 \mathrm{pp}$.

Kirby W (1798) Ammophila, a new genus of insect in the class Hymenoptera, including the Sphex sabulosa of Linnaeus. Transactions of the Linnean Society of London, 4: 195-212

Kirby WF (1900) Descriptions of the new species of Hymenoptera. Bulletin of the Liverpool Museums under the City Council 3: $13-24$

Klug F (1845) Symbolae physicae seu icones et descriptiones Insectorum quae ex itinere per Africam borealem et Asiam occidentalem Frederici Guilelmi Hemprich et Christiani Godofredi Ehrenberg. Decas Quinta. Officina Academica, Berolini. 41 pp.

Kohl FF (1883a) Ueber neue Grabwespen des Mediterrangebietes. Deutsch. Ent. Zeitschr., 27: 161-186.

Kohl FF (1883b) Die Fossoren der Schweiz. Mitt. Schweiz. Ent. Ges., 6: 647-684.

Kohl FF (1883c) Zur Synonymie der Hymenopterengattung Tachysphex. Wiener Entomologische Zeitung, 2: 226

Kohl FF (1884) Beitrag suz Kenntnis der Hymenopterengattung Oxybelus. Termeszetrajzi Füzetek, 8: 101-116

Kohl FF (1885a) Die Gattungen und arten der Larriden Autorum. Verhandlungen der kaiserlich-königlichen ZoologischBotanischen Gesellschaft in Wien, 34 (1884): 171-268

Kohl FF (1885b) Die Gattungen der Sphecinen und die palaearktischen Sphex-Arten. Termeszetrajzi Füzetek, 9:154-207.

Kohl FF (1889) Bemerkungen zu Edm. André's Species des Hyménoptères, T.III (Les Sphégiens). Mit Beschriebungen einiger neuen Arten. Verhandlungen der kaiserlich-königlichen Zoologisch-Botanischen Gesellschaft in Wien 39: 9-30

Kohl FF (1890) Die Hymenopterengruppe der Sphecinen. I. Monographie der natürlichen Gattung Sphex Linné (sens. lat.). Annalen des kaiserlich-königlichen naturhistorischen Hofmuseums Wien, 5 (3), Abtheil I: 77-194, Abtheil II: 317-461.

Kohl FF (1891) Zur Kenntnis der Hymenopteren. Gattung Philanthus Fab.) sens. lat. Annalen des kaiserlich-königlichen naturhistorischen Hofmuseums Wien, 6 345-370

Kohl FF (1892) Neue Hymenopterenformen. Annalen des kaiserlich-königlichen naturhistorischen Hofmuseums Wien, 7 : 197-234 
Kohl FF (1894) Zur Hymenopterenfaunas Afrikas. Annalen des kaiserlich-königlichen naturhistorischen Hofmuseums Wien 9: 279-350.

Kohl FF (1895) Zur Monographie der natürlichen Gattung Sphex Linné. Annalen des kaiserlich-königlichen naturhistorischen Hofmuseums Wien, 10:42-74, pls. 4 \& 5 .

Kohl FF (1897) Eremiasphecium. Eine neue Gattung der Hymenoptera aus der Familie der Sphegiden. Annalen des kaiserlichköniglichen naturhistorischen Hofmuseums Wien, 12: 67-70

Kohl FF (1898) Ueber neue Hymenopteren. Természetrajzi Füzetek, 21: 327-367

Kohl FF (1901a) Zur Kenntnis der palaearktischen Diodontus-Arten. Verhandlungen der kaiserlich-königlichen ZoologischBotanischen Gesellschaft in Wien, 51: 120-134, pl.2.

Kohl FF (1901b) Ueber neue Arten der Hymenopteren-Gattung Tachysphex Kohl. Verhandlungen der kaiserlich-königlichen Zoologisch-Botanischen Gesellschaft in Wien, 51: 777-784

Kohl FF (1901c) Zur Kenntnis der Sandwespen (Gen. Ammophila Kirby). Annalen des kaiserlich-königlichen naturhistorischen Hofmuseums Wien, 16: 142-164

Kohl FF (1905) Palaearktische Crabronen (Hym.). Zeitschrift für Systematische Hymenopterologie und Dipterologie 5: 217 227

Kohl FF (1906a) Die Hymenopterengruppe der Sphecinen. III. Monographie der Gattung Ammophila W. Kirby (sens. lat. Ammophilinae Ashmead). Abteilung A. Die Ammophilinen der palaearktischen Region, ...

Kohl FF (1906b) Hymenoptera. In: Zoologische Ergebnisse der Expedition der kaiserliche Akademie der Wissenschaft nach Südarabien und Sokotra im Jahre 1898-1899 - Denkschriften der Akademie der Wissenschaften in Wien, 71: 169-301, pls. I-XI.

Kohl FF (1915) Die Crabronen der palaearktischen Region. Annalen des kaiserlich-königlichen naturhistorischen Hofmuseums Wien, 29: 1-453.

Kohl FF (1918) Die Hautflüglergruppe "Sphecinae”. IV. Die natürliche Gattung Sceliphron Klug (=Pelopaeus Latr.). Annalen des kaiserlich-königlichen naturhistorischen Hofmuseums Wien 32: 1-171

Kohl FF (1923) Die Hymenopteren-Gattung Belomicrus A. Costa (s.1.). Konowia, 2: 98-122, 180-202, 258-278.

Krombein KV (1969) Life History Notes on Some Egyptian Solitary Wasps and Bees and Their Associates. Smithsonian Contributions to Zoology, 19, 18pp.

Krombein KV (1974) Supplement to a List of the Wasps of Gebel 'Uweinat, Libyan Desert (Hymenoptera, Aculeata). Rev. Zool. Africana, 88: 450-452

Krombein KV (1982) Biosystematic studies of Ceylonese wasps, X: taxonomic and biological notes on some Oxybelinae (Hymenoptera: Sphecoidea, Crabronidae). Int. J. Ent. (India), 1 (1): 31-39.

Krombein KV \& WJ Pulawski (1986) Biosystematic Studies of Ceylonese Wasps, XVI: A Revision of Gastrosericus Spinola (Hymenoptera: Sphecoidea: Larridae). Smithsonian Contibutions to Zoology, 436: 20pp.

Krombein KV \& WJ Pulawski (1994) Biosystematic Studies of Ceylonese Wasps, XX: A Revision of Tachysphex Kohl, 1883, with Notes on Other Oriental Species (Hymenoptera: Sphecidae: Larrinae). Smithsonian Contributions to Zoology, 552, iv + 106pp., 257 figs.

Latreille PA (1792) Mutilles, Découvertes en France. Actes de la Société d’Histoire Naturelle de Paris 1: 5-12

Latreille PA (1809) Genera Crustaceorum et Insectorum. Amand Koenig, Paris. Vol. 4, 399 pp

Le Guillou EJF (1841) Catalogue Raisonné des Insectes Hyménoptères recueillis dans le voyage de circumnavigation des Corvettes l'Astrolabe et la Zelée. Ann. Soc. Ent. France, 10: 311-324 [Sphecidae: 319-321]

Lepeletier de Saint Fargeau ALM (1845) Histoire Naturelle des Hyémoptères, III. Hist. nat. Ins. Hym., 3, Paris: 1-646.

Lepeletier de Saint Fargeau ALM \& Audinet-Serville JG (1828) Encyclopédie méthodique, ou par ordre des matières. Histoire naturelle. Entomologie. Vol. 10: 345-833

Linden PL Van der (1827) Observations sur les Hyménoptères d'Europe de la famille de Fouisseurs, première partie. Scoliètes, Sapygides, Pomiliens et Sphégides. Nouvelles Mémoires de l'Academie Royale des Sciences et Belles Lettres de Bruxelles 5: 11-125

Linden PL Van der (1829) Observations sur les Hyménoptères d'Europe de la famille de Fouisseurs, deuxième partie. Bembecides, Larrates, Nyssoniens et Crabronites. Nouv. Nouvelles Mémoires de l'Academie Royale des Sciences et Belles Lettres de Bruxelles, 5: 11-125

Linnaeus C (1758) Systema Naturae. Vol. 1. 823 pp.

Linnaeus C (1771) Pandora et Flora Rybijensis. Erlangen. Vol 8, 332 pp.

Lohrmann E (1942) Neue Bembecinen und Stizinen (Hym. Sphegidae). Mitteilungen der Münchner Entomologische Gesellschaft, 32: 208-213.

Lohrmann E (1943) Die Grabwespengruppe der Stizen. -berschau und Stammesgeschichte. Mitteilungen der Münchner Entomologische Gesellschaft, 33:188-208.

Lohrmann E (1948) Die Grabwespengruppe der Bembicinen. -berschau und Stammesgeschichte. Mitteilungen der Münchner Entomologische Gesellschaft, 34: 420-471.

Lucas H (1846-49) Exploration scientifique de l'Algérie pendant les années 1840,1841 et 1842. publiée par ordre du gouvernment et avec le concours d'une commission académique, Sciences physiques, Zoologie,3. Histoire naturelle des animaux articulés, 3. Insectes, Paris: 1-527. (Sphecidae on pp 241-280 pub. in 1848)

Magretti P (1884) Risultati di raccolte imenotterologiche nell'Africa orientale. Annali del Museo Civico di Storia Naturale di Genova 21: 523-636

Maidl F (1924) Wissenschaftliche Ergebnisse der mit Unterstützung der Akademie der Wissenschaften in Wien aus der Erbschaft Treitl von F.Werner unternommenen zoologischen Expedition nach dem Anglo-Aegyptischen Sudan (Kordofan) 1914. XV. Hymenoptera E. Scoliidae et Sphegidae. Denkschriften der Akademie der Wissenschaften in Wien. Mathematisch-Naturwissenschaftliche Klasse. Abteilung I. 99: 233-246 
Menke AS (1966) The identity of Parapsammophila lutea Tachenberg, 1869 (Hymenoptera, Sphecidae). Polskie Pismo Entomologiczne 36 (4): 57-61.

Mercet RG (1909) Especies nuevas de Tachysphex. Boletin de la Real Sociedad Española de Historia Natural, 9 194-199

Mochi A (1939a) Revisione delle Specie egiziane del Genero Cerceris Latr. (Hymenoptera: Sphegidae - Philanthinae). Bulletin de la Société Fouad 1er d'Entomologie, 22 (1938): 136-229.

Mochi A (1939b) Revisione delle Specie egiziane dei Generi Philanthus F. e Nectanebus Spin. (Hymenoptera: Sphegidae Philanthinae). Bulletin de la Société Fouad 1er d'Entomologie, 23: 86-138, pls.1-6

Mochi A (1939c) Revisione delle Specie egiziane del Genere Stizus Latr. (Hymenoptera: Sphegidae). Bulletin de la Société Fouad 1er d'Entomologie, 23: 183-237, pls. 1-7.

Mochi A (1940) Ammoplanopterus nov. gen. sinaiticus nov. spec. (Hymenoptera: Sphecidae - Pemphredoninae). Bulletin de la Société Fouad 1er d'Entomologie, 24: 27-40.

Mochi A \& A Mochi (1938) Laphyragogus pictus Kohl: complemento alla descrizione della femmina e descrizione del maschio (Hymenoptea - Sphegidae). Bulletin de la Société Royale Entomologique d'Egypte, 21 (1937): 223-231.

Mocsáry A (1881) Drei neue Hymenopteren. Entomologische Nachrichten, 7: 327-330

Mocsáry A (1883) Hymenoptera nova Europaea et exotica. Ertekezések Természettudomanyok Köréböl, 13(11): 1-72

Morawitz F (1889) Insecta, A. Cl. G. N. Potanin in China et in Mongolia novissima lecta, IV, Hymenoptera Aculeata. Horae Societatis Entomologicae Rossicae, 23: 112-168

Morawitz F (1890) Hymenoptera Fossoria transcaspica nova. Horae Societatis Entomologicae Rossicae, 24: 349-385

Morawitz F (1891) Ueber Astrachan'sche Fossorien. Horae Societatis Entomologicae Rossicae, 25: 175-233

Morawitz F (1894) Beitrag zur Raubwespenfauna Turkmeniens. Horae Societatis Entomologicae Rossicae, 28: 327-365

Morawitz F (1896) Ueber einige transcaspische Raubwespen. Horae Societatis Entomologicae Rossicae 30: 144-160

Morice FD (1897a) New or little-known Sphegidae from Egypt. Trans. ent. Soc. London, 1897(3): 301-316 + pl. VI.

Morice FD (1897b) New or little-known Sphegidae from Egypt - a Correction. Trans. ent. Soc. London, 1897: 434. [Also shown as Proc. ent. Soc. London, 1, 1897: 434]

Morice FD (1900a) An excursion to Egypt, Asia Minor, \&c. in search of Aculeate Hymenoptera. Entomologist's Monthly Magazine 36:164-172

Morice FD (1900b) Descriptions of new or doubtful species of the genus Ammophila Kirby from Algeria. Annals \& Magazine of Natural History, (7) 5: 64-70

Morice FD (1911) Hymenoptera aculeata collected in Algeria. The Sphegidae. Trans. Ent. Soc. London, 1911: 62-135.

Nurse CG (1903) New species of Indian Hymenoptera. Annals \& Magazine of Natural History (7) 11: 511-26

Nurse CG (1909) New or little known Indian Hymenoptera. Journal of the Bombay Natural History Society, 19: 510-517

Olivier AG (1812) Oxybèle. pp. 592-597 in AG Olivier \& PA Latreille (eds) Encyclopédie Methodique, Histoire Naturelle, Insectes, vol.8 (1811), $722 \mathrm{pp}$.

Osborn DJ \& KV Krombein (1969) Habitats, Flora, Mammals, and Wasps of Gebel 'Uweinat, Libyan Desert, Smithsonian Contibutions to Zoology, 1969, 11, 18pp.

Panzer GWF (1799) ?? [OD of Cerceris sabulosa, quadricincta]

Panzer GWF (1801) Nachrichten von einem neuen entologischen Werke des Hrn. Prof. Jurine in Geneve. 2 vols. Erlangen.

Panzer GWF (1804) Kritische Revision der Insektenfauna Deutschlands nach dem System bearbeitet. Nürnberg, $271 \mathrm{pp}$.

Panzer GWF (1806-1809) Entomologischer Versuch die Jürineschen Gattungen der Linnéschen Hymenopteren. Nürnberg, 270 pp.

Panzer GWF (1809) Faunae Insectorum Germaniae initia oder Deutschlands Insecten. 9 Jahrgang. Nürnberg

Pic H (1917) Notes Hyménoptèrologiques. L’Echange, Revue Linnéenee No. 381: 1-4

Piccioli F (1869) Descrizione di un nuovo genere d'Imenotteri della famiglia degli Sfecidei spettante alla fauna toscana. Bollettino della Societa Entomologica Italiana 1: 282-5

Piek T (1986) Morphological and physiological differences between Philanthus triangulum (Fabricius, 1775), and its African subspecies abdelcader Lepeletier de Saint Fargeau, 1845, (Hymenoptera: Sphecidae). Entomologische Berichten, 46: 190-192.

Priesner H (1958) The Egyptian species of the genus Bembyx F. (Hymenoptera: Sphecidae). Bull. Soc. Entom. Egypte, 42: 136.

Pulawski WJ (1958) Une espèce paléarctique du genre Diploplectron Fox (Hymenoptera: Sphecidae). Bull. Soc. entom. Egypte, 42: 473-476.

Pulawski WJ (1959) Espèces nouvelles ou peu connu du genre Astata Latr. (Hym., Sphecid.). Polskie Pismo Entomologiczne, 29 (18): 359-416.

Pulawski WJ (1961) Remarques sur les Parapiagetia Kohl d'Egypte Hym., Sphecidae). Polskie Pismo Entomologiczne, 31 (7): 85-92.

Pulawski WJ (1962) Les Tachytes Panz. de la région paléarctique occidentale et centrale (Hym., Sphecidae). Polskie Pismo Entomologiczne, 32 (22): 311-475.

Pulawski WJ (1964) Etudes sur les Sphecidae (Hym.) d'Egypte. Polskie Pismo Entomologiczne, 34 (6): 63-155.

Pulawski WJ (1965b) Sur la synonymie de certains Sphecidae (Hym.) paléarctiques. Polskie Pismo Entomologiczne), 35 (19): 563-578.

Pulawski WJ (1967) Hymenoptera from Turkey. Sphecidae, II (Genera Astata Latreille and Tachysphex Kohl). Bull. Brit. Mus. (Nat. Hist.) Ent. 19: 383-410.

Pulawski WJ (1971) Les Tachysphex Kohl (Hym. Sphecidae) de la région paléarctique occidentale et centrale. Panstwoweaklad Zoologii Systematycznej i Doswiadczalnej Polskiej Akademii Nauk, Wroclaw, 464 pp.

Pulawski WJ (1972) Notes synonymiques sur quatre Sphecidae (Hym.) paléarctiques. Polskie Pismo Entomologiczne), 42 (4) 817-820.

Pulawski WJ (1973) Astata, Tachytes \& Tachysphex in de Beaumont \& Bytinski-Salz, The Sphecidae (Hymen.) of Erez Israel. Israel Journal of Entomology, 8: 1-21. 
Pulawski WJ (1975) Synonymical Notes on Larrinae and Astatinae (Hymenoptera: Sphecidae). J. Wash. Acad. Sci, 64 (4): 308-322.

Pulawski WJ (1977) A revision of the Old World Parapiagetia Kohl (Hymenoptera, Sphecidae). Polskie Pismo Entomologiczne, 47: 601-669.

Pulawski WJ (1979) A revision of the World Prosopigastra Costa (Hymenoptera, Sphecidae). Polskie Pismo Entomologiczne, 49: 3-134.

Pulawski WJ (1982) New Synonyms in Old World Sphecidae (Hymenoptera). Mitt. Schweiz. Entomol. Ges., 54: 353-366

Pulawski WJ (1983) Identification and Synonymies of Two Western Palearctic Cerceris: maculata Radoszkowski and hathor n. sp. (Hymenoptera: Sphecidae). Pan-Pacific Entomologist, 59 (1-4): 240-245.

Pulawski WJ (1992a) World species of the wasp genus Holotachysphex de Beaumont (Hymenoptera: Sphecidae). Proceedings of the Entomological Society of Washington, 94 (2): 223-242.

Pulawski WJ (1992b) A review of Eremiasphecium Kohl, 1897 (Hymenoptera: Sphecidae). Entomofauna, Zeitschrift für Entomologie, 13 (24): 397-406.

Pulawski WJ (1995) The Wasp Genus Gastrosericus Spinola, 1839 (Hymenoptera, Sphecidae). Memoirs of the California Academy of Sciences no. 18, $173 \mathrm{pp}$.

Pulawski WJ (2007) The wasp genus Tachysphex Kohl, 1883, of Sahara, sub-Saharan Africa, the Arabian Peninsula and Madagascar (Hymenoptera: Apoidea: Crabronidae). Proceedings of the California Academy of Sciences ( $4^{\text {th }}$ series $) 58$, Supplement 1: 1-698

Radoszkowski O (1876) Compte rendu des Hyménoptères recueillis en Egypte et Abyssinie en 1873. Horae Societatis Entomologicae Rossicae 20: 111-150

Radoszkowski O (1877) Sphegidae [in:] Voyage au Turkestan d'A.P.Fedtchenko, fasc. 14 tome 2, partie 5, Izvestiya Imperatorskovo Obshchestva Lyubitelei Estestvoznaniya Antropologii i Etnografii pri Imperatorskom Moskovskom Universitete, 26: 1-87 + pl. I-VIII.

Radoszkowski O (1884) Etude hyménoptérologique [sic]. Horae Societatis Entomologicae Rossicae, 18: 23-29

Radoszkowski O (1886) Faune Hyménoptérologique Transcaspienne. Horae Societatis Entomologicae Rossicae, 20: 3-56 + pl. I-XI.

Radoszkowski O (1887) Insecta in itinere Cl. N. Przewalskii in Asia centrali novissime lecta. III. Sphegidae. Horae Societatis Entomologicae Rossicae, 21: 41-52 + pl. II et III

Richards OW (1928) The species of Notogonia (Hymenoptera, Larridae) occurring in the Mediterranean Basin. Proceedings of the General Meetings for Scientific Business of the Zoological Society of London 1928: 357-363

Roche CG (2007) The Sphecidae (Hym.) of Egypt. Part 2: Checklist. Egyptian Journal of Natural History 4: 1-15

Roche GC \& Gadallah NS (1999) The sphecid wasps of Egypt (Hymenoptera: Sphecidae): Introduction and generic key. Egyptian Journal of Biology 1:104-117.

Roche CG \& Zalat SM (1994) The Sphecidae (order: Hymenoptera) of the Sinai Peninsula. pp. 113-118 in Proceedings of the First Egyptian-Hungarian Conference on Environment, St. Catherine, Sinai, Egypt. April 5-7, 1993. Suez Canal University, Ismailia. $323 \mathrm{pp}$

Rossi P (1790) Fauna Etrusca. Livorno. Vol. 2, 348 pp

Rossi P (1792) Mantissa Insectorum. Pisa. Vol. 1, 148 pp

Rossi P (1794) Mantissa Insectorum. Pisa. Vol. 2, 154 pp

Roth P (1925) Les Sphex de l'Afrique du nord. Annales de la Société entomologique de France, 94: 365-404.

Roth P (1928) Les Ammophiles de l'Afrique du nord. Annales de la Société entomologique de France, 97: 154-240.

Roth P (1934) Description d'un nouveau Stizus capturé au Sahara central par M. Th. Monod (Hym. Sphegidae). Bulletin de la Société entomologique de France, 39 (17): 253-255.

Saunders E (1910) Hymenoptera Aculeata collected in Algeria by the Rev. Alfred Edwin Eaton, M.A., F.E.S., and the Rev. Francis David Morice, M.A. F.E.S. Part IV. Descriptions of new Sphegidae. Trans Ent. Soc. London, 1910: 517-531.

Saussure H de (1854) Mélanges hyménoptérologiques. Mémoires de la Société de Physique et d'Histoire Naturelle de Genève 14: $1-76$

Saussure H de (1867) Reise der österreichischen Fregatte Novara um die Erde in den Jahre 1857, 1858, 1859 unter den Befehlen des Commodore B. von Wüllerstorf-Urbair. Zoologischer Theil, Zweiter Band. Hymenoptera. Familien der Vespiden, Sphegiden, Pompiliden, Crabroniden und den Heterogynen. Wien: 1-138 + pl.I-IV.

Sayed MT, ZMF Rostom \& AH Kashef (1964) Contributions to the insect fauna of some oases of the Egyptian Western Desert. Bulletin de la Société entomologique d'Egypte, 48: 259-267.

Schletterer A (1887) Die Hymenopteren-Gattung Cerceris Latr. mit vorzugsweiser Berücksichtigung der paläarktischen Arten. Zoologische Jahrbücher, Abteilung für Systematik, Geographie und Biologie der Thiere 2: 349-510

Schletterer A (1889) Nachträgliches über die Hymenopteren-Gattung Cerceris Latr. Zoologische Jahrbücher, Abteilung für Systematik, Geographie und Biologie der Thiere, 4: 879-904

Schrank F de P (1781) Enumeratio Insectorum Austriae indigenorum. Augsburg. 548 pp.

Schreber ICD (1759) Novae species Insectorum. Magdeburg. 16 pp.

Schulthess A von (1925) Oxybelus (Hym. Crabronidae) nova species. Konowia 4: 187-8

Schulthess A von (1926) Neue Grabwespen aus Nordafrika. Konowia, 5: 150-160

Schulthess A von (1927) Zur Erforschung des Persischen Golfes. Hymenoptera, Vespiden und Sphegiden. Stettiner entomologische Zeitung 88: 297-304.

Schulz WA (1904) Ein Beitrag zur Faunistik der palaearktischen Spheciden. Zeitschr. Ent., N.F., 29: 90-102

Scopoli JA (1763) Entomologia Carniolica. Vindobonae. 420 pp.

Simonthomas RT \& AMJ Simonthomas (1986) Philanthus triangulum and its recent eruption as a predator of honeybees in an Egyptian oasis. Bee World, 61 (3): 97-107.

Smith F (1851) Descriptions of some new species of British Hymenoptera. The Zoologist: a popular miscellany of Natural History 9 (Appendix): 120-127 
Smith F (1856) Catalogue of Hymenopterous insects in the collection of the British Museum. Part IV. Sphegidae, Larridae, and Crabronidae. London: [4] + 207-497 + pl.VI-XI.

Smith F (1873) Descriptions of new species of fossorial Hymenoptera in the collection of the British Museum, and of a species of the rare genus Iswara, belonging to the family Dorylidae. Annals \& Magazine of Natural History (4) 12: 253-260; 291-300; 402-415.

Spinola M (1805) Faunae Liguriae Fragmenta. Decas 1, Genuae: 1-21 + a pl.

Spinola M (1806-1808) Insectorum Liguriae species novae aut rariores quas in agro Ligustico nuper detexit, descripsit, et iconibus illustravit Maximilianus Spinola, adjecto catalogo specierum auctoribus jam enumiratis, quae in eadem regione passim occurrunt. Genuae, 1 (1806): 1-159 + 2 pl.; 2 (1808): 1-262 + 5 pl.

Spinola M (1839) Compte-rendu des Hyménoptères recueillis par Monsieur Fischer pendant son voyage en Egypte, et communiqués par M. le Docteur Waltl à Maximilian Spinola. Annales de la Société entomologique de France, 7: 437546. [Sphecidae: 464-500]

Storey G (1916) List of the Hymenoptera Tubulifera and Aculeata in the Collection of the Ministry of Agriculture of Egypt. Bull. Soc. Entom. Egypte, 4, 1914-1915 [1916]: 100-117.

Taschenberg EL (1869) Die Sphegidae des zoologischen Museums der Universität in Halle. Zeitschrift für die gesammten Naturwissenschaften, Halle, 34: 407-435

Taschenberg EL (1875) Nyssonidae and Crabronidae des zoologischen Museums der hiesigen Universität. Zeitschrift für die gesammten Naturwissenschaften, Halle, 46: 359-409

Thunberg CP (1815) Philanthi, generis insecti Hymenopteri, monographia. Nova Acta K Vetenskaps-Societaten i Uppsala (Nova Acta Regiae Societatis Scientarum Upsaliensis) 7: 126-139

Turner R (1916) Notes on the wasps of the genus Pison and some allied genera. Proceedings of the General Meetings for Scientific Business of the Zoological Society of London 1916: 591-629

Turner RE (1917) Ann. Mag. Nat. Hist., 9 (8): [OD of Tachytes comberi, Pison carinatum]

Turner RE (1918) Notes on fossorial Hymenoptera, XXXII. On new Species in the British Museum. Ann. Mag. Nat. Hist., (9) 1: 89-96.

Turner RE (1919) One a collection of Sphecoidea sent by the Agricultural Research Institute, Pusa, Bihar. Memoirs of the Department of Agriculture in India. Entomological Series 5: 173-205

Turner RE (1920) Notes on fossorial Hymenoptera - XL. On new species in the British Museum. Annals \& Magazine of Natural History (9) 5: 265-270

Turton W (1801) A general system of nature. Swansea. Vol III. 784 pp.

Vecht J van der (1973) Contribution to the taxonomy of the Oriental and Australian Sphecini (Hymenoptera Sphecoidea). Proc. K. ned. Akad. Wet., C76: 341-353.

Vecht J van der \& FMA van Breugel (1968) Revision of the nominate subgenus Sceliphron Latreille (Hymenoptera, Sphecidae) (Studies on the Sceliphronini, part I). Tijdschrift voor Entomologie, 111 (6): 185-255, figs. 1-27.

Verhoeff PMF (1948) Systematisches Verzeichnis der niederländischen Oxybelus-Arten (Oxybelus Latr., Hym. Sphec.), mit Berücksichtigung palaearktischen Arten und Rassen. Tijdschrift voor Entomologie, 89 (1946): 158-208.

Verhoeff PMF (1955) Zur Taxonomie der palaearktischen Miscophus (Hym. Sphecid.), (1. Beitrag). Entomologische Berichten, 15: 374-382.

Walker F (1871) List of Hymenoptera collected by J.K.Lord in Egypt, in the neighbourhood of the Red Sea and in Arabia. London, pp. [i]-iv, [1]-59.

Waltl J (1835) Reise durch Tyrol, Oberitalien und Piedmont nach dem südlichen Spanien. Zweiter Theil. Ueber die Thiere Andalusiens. Passau. 120 pp. 